\title{
LÁGYROTHADÁST, ILLETVE HAJTÁSSZÁRADÁST OKOZÓ BAKTÉRIUMOS BETEGSÉGEKKEL SZEMBENI ELLENÁLLÓKÉPESSÉG VIZSGÁLATA IN VITRO BURGONYA- ÉS ALMANÖVÉNYEKEN
}

Doktori értekezés

\section{Hudák Ildikó}

Témavezető: Dr. Tóth Magdolna, DSc egyetemi tanár

Társkonzulens: Dr. Hevesi Mária, CSc

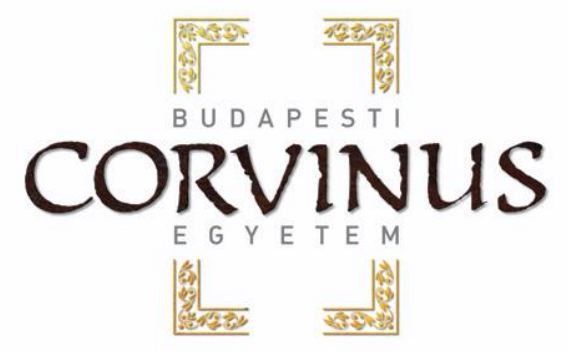

Budapesti Corvinus Egyetem

Gyümölcstermő Növények Tanszék

Budapest

2014 


\section{A doktori iskola}

megnevezése: Kertészettudományi Doktori Iskola

tudományága: Növénytermesztési és Kertészeti Tudományok

vezetője: $\quad$ Dr. Tóth Magdolna

egyetemi tanár, DSc

Budapesti Corvinus Egyetem, Kertészettudományi Kar,

Gyümölcstermő Növények Tanszék

Témavezető: $\quad$ Dr. Tóth Magdolna

egyetemi tanár, DSc

Budapesti Corvinus Egyetem, Kertészettudományi Kar,

Gyümölcstermő Növények Tanszék

Társkonzulens: Dr. Hevesi Mária

ny. tudományos fömunkatárs, CSc.

Budapesti Corvinus Egyetem, Kertészettudományi Kar,

Gyümölcstermő Növények Tanszék

A jelölt a Budapesti Corvinus Egyetem Doktori Szabályzatában elöírt valamennyi feltételnek eleget tett, az értekezés mühelyvitájában elhangzott észrevételeket és javaslatokat az értekezés átdolgozásakor figyelembe vette, azért az értekezés nyilvános vitára bocsátható.

Dr. Tóth Magdolna

$A z$ iskolavezető jóváhagyása
Dr. Tóth Magdolna

A témavezető jóváhagyása 
A Budapesti Corvinus Egyetem Élettudományi Területi Doktori Tanács 2014. június 3-i határozatában a nyilvános vita lefolytatására az alábbi Bíráló Bizottságot jelölte ki:

BÍRÁLÓ BIZOTTSÁG:

Elnöke

Palkovics László, DSc

Tagjai

Király Ildikó, PhD

Kruppa József, PhD

Papp István, PhD

Schwarczinger Ildikó, PhD

Opponensek

Ficzek Gitta, PhD

Janda Tibor, DSc

Titkár

Király Ildikó, PhD 


\section{TARTALOMJEGYZÉK}

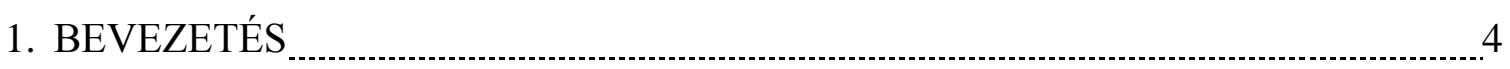

2. IRODALMI ÁTTEKINTÉS

2.1. A vizsgálatba vont növényfajok szerepe a termesztésben és a

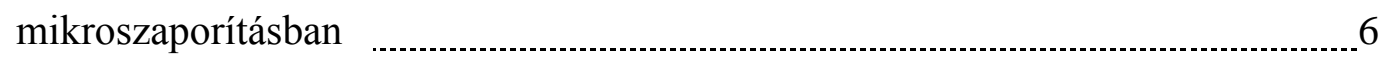

2.1.1. A burgonya jelentősége és mikroszaporitásának lehetősége _.................... 6

2.1.2. Az alma jelentősége és mikroszaporításának lehetősége ............................ 8

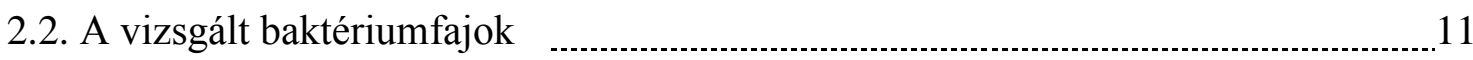

2.2.1. A burgonyát károsító baktériumfajok, az előidézett betegségek és a védekezési lehetőségek ....................................................................11

2.2.2. Az almát károsító baktériumfaj ………………………………………...22

2.3. Kiemelések a növényi stresszfolyamat ismeretköréből és a növények

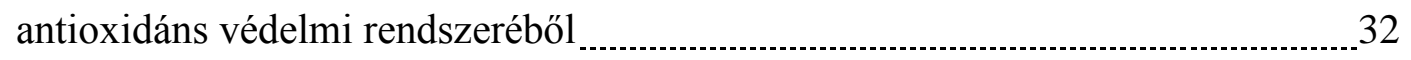

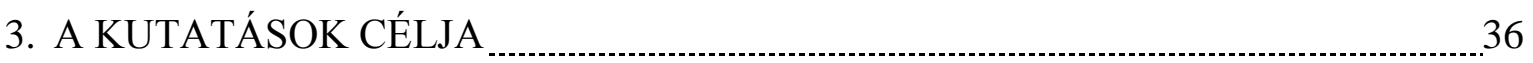

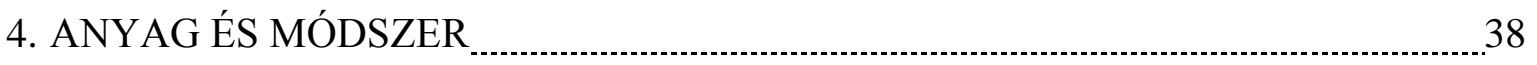

4.1. Felhasznált anyagok $\ldots \quad 38$

4.1.1. Baktériumfajok azonosítása, biokémiai tulajdonságaik és

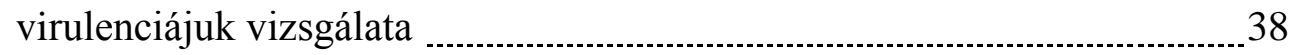

4.1.2. Burgonya - és almafajtákból elöállított in vitro növények _......................... 40

4.2. A fertőzések és tünetértékelések vizsgálati módszerei $\quad 40$

4.2.1. Burgonyafajták hajtásfertőzése in vitro körülmények között ………........ 41

4.2.2. Burgonya mikrogumó fertőzése in vitro körülmények között _.................... 43

4.2.3. Primer burgonyagumó fertőzése üvegházi körülmények között_................... 44

4.2.4. Mikroszaporított almafajták hajtásfertőzése ……................................... 45

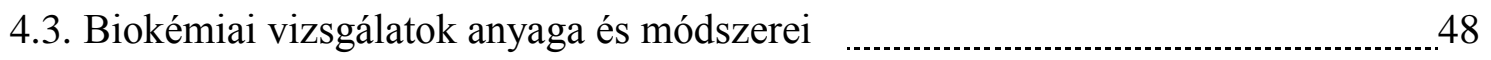

4.3.1. A kísérletbe bevont növényfajok/fajták és mintavételek ……....................4 48

4.3.2. Vizsgálati módszerek $\quad 48$

4.3.2.1. Peroxidáz enzimaktivitás fotometriás meghatározása …................. 48

4.3.2.2. Szénhidráttartalom meghatározása $\quad 49$

5. EREDMÉNYEK $\quad 50$

5.1. Az API 20E és API 50CH tesztetek eredményei

5.2. Burgonyafajták fogékonysága a baktériumfajokkal szemben _............................. 52

5.2.1. In vitro burgonyafajták fogékonysága a hajtásfertőzés alapján ................... 52 
5.2.1.1. A Pectobacterium carotovorum subsp. carotovorum fertőzés hatása

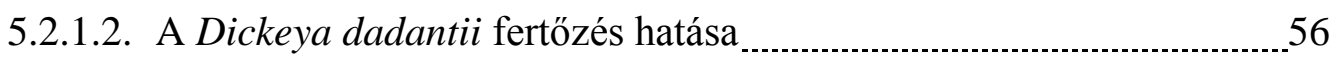

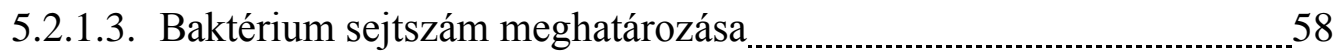

5.2.2. Burgonya mikrogumók fogékonysága a gumófertőzés alapján _.................. 61

5.2.2.1. A Pectobacterium carotovorum subsp. carotovorum fertőzés hatása 61

5.2.2.2. A Dickeya dadantii fertőzés hatása 63

5.2.3. Primer burgonyagumók fogékonysága a gumófertőzés alapján 66

5.2.3.1. A Pectobacterium carotovorum subsp. carotovorum fertőzés hatása 66

5.2.3.2. A Dickeya dadantii fertőzés hatása 67

5.3. Almafajták fogékonysága 69

5.3.1. Baktérium sejtszám meghatározása 71

5.4. Biokémiai vizsgálatok eredményei 73

5.4.1. Peroxidáz enzimaktivitás változások Pectobacterium carotovorum subsp. carotovorum fertőzés következtében 73

5.4.2. Szénhidráttartalom alakulása Pectobacterium carotovorum subsp. carotovorum fertőzés következtében 74

5.4.3. Peroxidáz enzimaktivitás változások Dickeya dadantii fertőzés következtében 76

5.4.4. Szénhidráttartalom alakulása Dickeya dadantii fertőzés következtében

5.4.5. Peroxidáz enzimaktivitás változások Erwinia amylovora fertőzés következtében 79

5.4.6. Szénhidráttartalom alakulása Erwinia amylovora fertőzés következtében 80

5.5. Új tudományos eredmények 85

6. MEGVITATÁS, KÖVETKEZTETÉSEK

7. ÖSSZEFOGLALÁS

8. SUMMARY 95

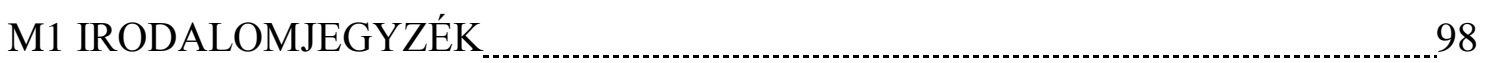

M2 TÁBLÁZATOK

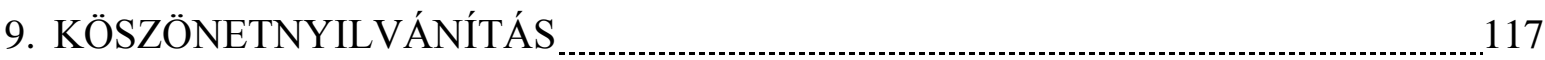




\section{Rövidítések jegyzéke}

\begin{tabular}{|c|c|}
\hline APX & aszkorbát peroxidáz \\
\hline CAT & kataláz \\
\hline $\mathrm{Dd}$ & Dickeya dadantii \\
\hline $\mathrm{Ea}$ & Erwinia amylovora \\
\hline EDTA & etiléndiamin-tetraecetsav \\
\hline FAO & Food and Agriculture Organization of the United Nations \\
\hline $\mathrm{F}_{\mathrm{i}}$ & fertőzési index \\
\hline GR & glutation reduktáz \\
\hline $\mathrm{H}_{2} \mathrm{O}_{2}$ & hidrogén-peroxid \\
\hline HPLC & High Pressure Liquid Chromatography \\
\hline $\mathrm{KSH}$ & Központi Statisztikai Hivatal \\
\hline MS & Murashige and Skoog táptalaj \\
\hline NAD(P)H oxidáz & nikotinsavamid adenin dinukleotid foszfát-oxidáz \\
\hline Pca & Pectobacterium carotovorum subsp. artosepticum \\
\hline Pcc & Pectobacterium carotovorum subsp. carotovorum \\
\hline PLRV & potato leafroll virus \\
\hline POD & peroxidáz \\
\hline PVA & Potato Virus A \\
\hline PVM & Potato Virus M \\
\hline PVS & Potato Virus S \\
\hline PVX & Potato Virus X \\
\hline PVY & Potato Virus Y \\
\hline ROS & Reactive Oxygen Species \\
\hline SOD & szuperoxid dizmutáz \\
\hline SPSS & Statistical Package for the Social Sciences \\
\hline $\mathrm{U}$ & unit \\
\hline
\end{tabular}




\section{BEVEZETÉS}

A környezeti és természeti tényezők változása új biotikus és abiotikus stresszfaktorok megjelenését idézte elő hazánkban is. Fontos nemesítési cél a megfelelő termésbiztonság elérése, amelyet döntően befolyásol egy adott növényfaj/fajta stressztürése, azaz a káros biotikus és abiotikus hatásokkal szembeni ellenállóságuk mértéke. Az ilyen stresszhatások közül hazánkban az utóbbi években jelentős termésveszteségeket idéztek elő a különböző baktériumos betegségek, így az Erwinia fajok okozta elváltozások is.

A különböző Erwinia fajok egymástól teljesen eltérő betegségtüneteket váltanak ki a gazdanövényeken, számos növény mellett a régiónkban nagy jelentőséggel bíró burgonyán és almán idéznek elő jelentős károsodásokat. A burgonyát károsító Erwinia fajok (Erwinia carotovora subsp. carotovora és Erwinia carotovora subsp. atroseptica), valamint az Erwinia chrysanthemi) gazdanövényeik húsos növényi szöveteiben pektinbontó képességüknél fogva ún. lágyrothadást okoznak. Ezzel szemben az Erwinia amylovora pektin bontására nem képes, hanem a Rosaceae család számos növényfaján hajtáselhalást, rákosodást idéz elö.

A molekuláris biológiai kutatások eredményeként a burgonyát károsító baktériumfajok taxonómiai besorolása az ismeretek bővülése következtében többször változott az évek során (Waldee, 1945, Hauben et al., 1998). Az Erwinia nemzetség molekuláris genetikai vizsgálatai alapján az Erwinia carotovora subsp. carotovora-t és az Erwinia carotovora subsp. atroseptica-t átsorolták a Pectobacterium nemzetségbe. 2005-ben pedig az Erwinia chrysanthemi-t sorolták át a Dickeya nemzetségbe, melynek hat különbözö biotípusát különböztetik meg (Samson et al., 2005). Ennek megfelelően az Erwinia carotovora subsp. carotovora ma érvényben lévő elfogadott neve a Pectobacterium carotovorum subsp. carotovorum (továbbiakban Pcc) (Jones, 1901) Hauben et al. (1998), az Erwinia carotovora subsp. atrosepticáé a Pectobacterium carotovorum subsp. atrosepticum (továbbiakban Pca) (van Hall, 1902) Hauben et al. (1998), és az Erwinia chrysanthemié a Dickeya dadantii (továbbiakban Dd) (Burkholder et al. 1953) Samson et al. (2005).

Sem a Pectobacterium, sem a Dickeya fajok nem tartoznak a burgonya zárlati károsítói közé sem hazánkban, sem Európában. Földrajzi elterjedésük igen széles körü, gyakorlatilag mindenütt előfordulnak, ahol burgonyát termesztenek, ezáltal komoly gazdasági károkat okozhatnak szerte a világon. Hazánkban laboratóriumi diagnosztikai vizsgálatokra olyan esetekben kerül sor, amikor az állományban jelentős arányban szártőrothadásos tüneteket észlelnek, vagy felmerül a zárlati Ralstonia solenacearum fertőzés gyanúja. Németh (2013) szerint hazánkban a legjelentősebb baktériumos eredetű burgonya tőpusztulással járó esetekben kiváltó kórokozóként 
Dickeya fajt azonosítottak. 2001 és 2011 között vizsgálták a Pectobacterium és Dickeya fajok hazai előfordulását és arra az eredményre jutottak, hogy a következő gyakorisági sorrendet lehet felállítani: Dickeya fajok (77\%), Pcc (16\%) és Pca (6\%). 2007-ben Hollandiában csak a Dickeya fajok közel 30 millió $€$ veszteséget okoztak a burgonya vetőgumó kereskedelemben (Slawiak et al. 2008). Az ellenük való védekezés a mai napig nem megoldott. Megoldást jelenthetne az ellenálló fajták bevonása a termesztésbe.

Az Erwinia amylovora (Burill) Winslow et al. (továbbiakban $E a$ ) az egész világon problémát jelent, az általa okozott tüzelhalás a legnehezebben leküzdhető betegségek egyike. Mivel a növényvédőszeres védekezés lehetőségei korlátozottak, az egyik legköltségkímélőbb lehetőség szintén az ellenállóbb fajták köztermesztésbe vonása lenne. Mivel a tüzelhalás kórokozója karantén károsító, ezért a fajták fogékonysága szabadföldi kísérletekben nem tesztelhető, kizárólag laboratóriumi körülmények között végezhetők vizsgálatok.

Mikroszaporított növényeken végzett fertőzések hatására bekövetkező biokémiai változásokról szóló szakirodalom elenyésző számban áll rendelkezésünkre. Ráadásul előfordul, hogy ezek eltérő eredményeket közölnek. Ezért tartottuk fontos feladatunknak a biotikus stressz hatására létrejövő gazdaválasz nyomonkövetését biokémiai markerekkel. Azt szeretnénk tisztázni, hogy az eltérő betegségtípusokra azonosan vagy eltérően reagálnak a növények. Mivel a biokémiai változásokat a fertőzés hatására csak azonos körülmények között tartott növényeken lehet követni, ezért volt szükség az in vitro elöállított növényekre. 


\section{IRODALMI ÁTTEKINTÉS}

\subsection{A vizsgálatba vont növényfajok szerepe a termesztésben és a mikroszaporításban}

\subsubsection{A burgonya jelentősége és mikroszaporításának lehetősége}

A burgonyafélék (Solanaceae) családjába tartozó burgonya (Solanum tuberosum L.) fontos népélelmezési cikk. Világszerte termesztett élelmiszernövény, amely a rizs (Oriza sativa L.), a búza (Triticum aestivum L.), a cukornád (Saccharum officinarum L.) és a kukorica (Zea mays L.) után az ötödik helyen áll mind a termesztett területet, mind a teljes termést tekintve (FAO, 2012).

Kb. 22\%-os termésveszteség írható a különböző vírusos, bakteriális és gombás fertőzések, valamint a kártevők számlájára, mely éves szinten 65 millió tonna terméskiesést jelent a világon (Ross, 1986).

Hazánkban is az egyik legjelentősebb kultúrnövény, a nyírségi tájkörzetben kiemelkedő jelentőségü. Magyarországon 2011-ben az összes betakarított termés mennyisége 600123 tonna volt 21853 ha termőterületen. Ezzel szemben 2013-ban mindössze 19847 ha-ról összesen 443 246 tonna burgonya került betakarításra (KSH, 2013). Ez önmagában is jelentős csökkenés, ehhez jön még a szélsőséges időjárás és a különböző kórokozók és kártevők okozta terméskiesés.

A burgonya hagyományos (vegetatív) szaporításából adódóan két fö problémával kell szembenéznünk. Egyik az alacsony szaporodási ráta, a másik komoly probléma pedig az, hogy a burgonya nagyfokú fogékonyságot mutat számos bakteriális, gombás és vírusos betegségekkel szemben, melyek a szaporító anyaggal (gumóval) jelentős mértékben átadódnak az utódokba. Mindez jelentős termésveszteséget okoz, ráadásul a fajta leromlását eredményezi (Dobránszki és Magyarné, 2005).

A kórokozómentes anyagokra alapozott mikroszaporítási technológiával ezek a problémák áthidalhatók. A steril, vegetatív mikroszaporítás vagy más néven in vitro klónozás a növénybiotechnológiának az az ága, amelyet ma már széles körben alkalmaznak a gyakorlatban. Elméleti szempontból maga a szaporítás elve tulajdonképpen azonosnak tekinthető a hagyományos vegetatív szaporítási technikával, de a szaporításra felhasznált növényi rész olyan kicsi, hogy csak steril körülmények között, táptalajon tartható életben, illetve nevelhető fel. Hazai viszonyok között a kórokozómentes burgonya szaporítóanyag biotechnológiai módszerekre alapozott előállítása három fő, egymásra épülő lépésre bontható, melyek a következők:

- az in vitro szaporítóanyag elöállítása mikroszaporítással,

- primer és szekunder gumó előállítása izolált körülmények között, 
- vetőgumótermesztés szántóföldön (Magyarné és Dobránszki, 1997).

A mikroszaporítás a kórokozómentes burgonya szaporítóanyag előállításának a bevezető lépése. A burgonyát hajtástenyészet formájában tartjuk fenn in vitro körülmények között, és hónalji, illetve csúcsrügyekkel szaporítjuk, melynek lehetőségét az adja, hogy a rügyben található merisztémák genetikai stabilnak tekinthetök, így a fajtajellegek az utódokba nemzedékről nemzedékre változatlanul átadódnak (Dobránszki és Magyarné, 1997).

Az in vitro tenyésztés első lépése az indítás merisztémák izolálásával és tenyésztésével. A merisztémát felületi sterilizálás után sztereomikroszkóp alatt kimetszik, és ún. indító táptalajra helyezik. Burgonyánál a gumón megindult hajtások csúcsmerisztémájáról történik az indítás. Nagy jelentősége van az izolált merisztéma méretének; leggyakrabban a $0,1 \mathrm{~mm}$ x $0,3 \mathrm{~mm}$ nagyságú izolátumot preparálnak ki. Ebben az esetben az explantátumokból még nagy eséllyel $(90 \%<)$ történik meg a növényregeneráció, mely növények valószínüleg vírusmentesek lesznek. A táptalajra helyezett izolátumból egy-két hónap alatt 7-8 leveles in vitro növények fejlődnek (Dobránszki és Magyarné, 2005).

Mivel a burgonya mikroszaporítás célja a kórokozómentes szaporítóanyag előállítása, ezért a mikroszaporításba csak azokat a vonalakat vonjuk be, melyek a vírustesztet (leggyakrabban ELISA teszt) követően vírusmentesnek bizonyultak. Ha az alapanyag vírusmentesítése szükségessé válik, többféle módszert választhatunk, a jelenlévő vírusok típusától függően. A burgonyát fertőző több mint 20 vírus és viroid közül 6 vírusnak van kiemelkedő gazdasági jelentősége, ezek a levélsodró (PLRV), Y (PVY), A (PVA), M (PVM), S (PVS) és X (PVX) vírusok. A merisztéma izolálása és tenyésztése már önmagában is a vírusmentesítés egyik lehetősége. A hőkezelés önmagában vagy merisztématenyésztéssel kombinálva szintén sikeresen alkalmazható a PLRV, PVX, PVA és egyes viroidok esetén. Szükség lehet azonban kemoterápia alkalmazására is, különösen S vírussal fertőzött növények esetében (Dobránszki és Magyarné, 2005).

A burgonya mikroszaporítás során leggyakrabban hajtástenyészetekkel dolgozunk és a hajtások egyrügyes darabjait oltjuk át, a nóduszokon található hónaljrügyekből három-négy hét alatt új, átoltásra alkalmas gyökérrel is rendelkező hajtások fejlődnek. A kifejlett 3-5 hetes növénykék közvetlenül kiültethetők üvegházi körülmények közé. Amennyiben a 4-6 hetes növényeket nem tudjuk kiültetni vagy továbbszaporítani, a tenyészetek elöregednek, elpusztulnak. A mikroszaporítás során lehetőségünk van azonban egy másik végtermék, az in vitro gumó (=mikrogumó) előállítására is. A mikrogumók a hajtástenyészetekkel biológiailag egyenértéküek, azonban a felhasználásuk számos előnyt jelent: tárolás és szállítás könnyebb, az in vivo környezeti feltételekhez jobban alkalmazkodik (Dobránszki és Magyarné, 2005). Ma már 
mind az in vitro növényeket, mind a mikrogumókat felhasználjuk a vírusmentes szaporítóanyag előállítása során (1. ábra).
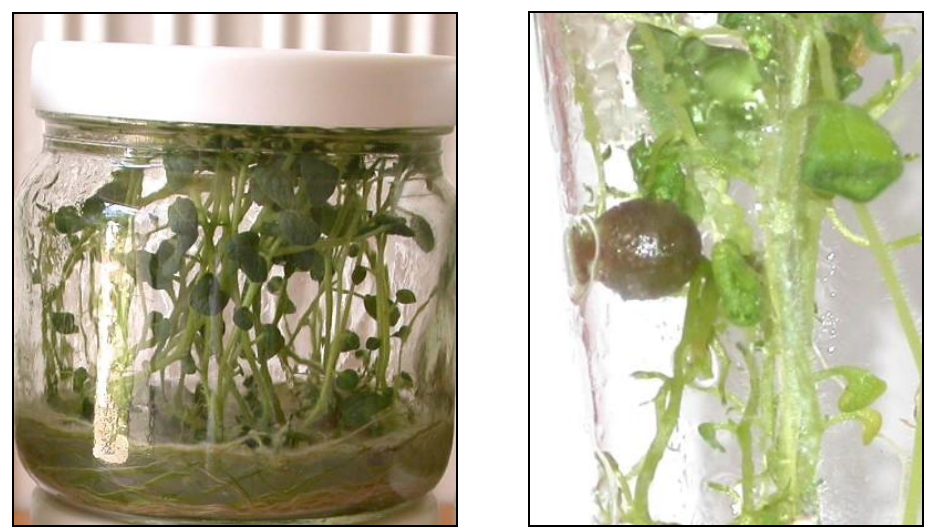

1. ábra. In vitro burgonyanövény és gumó (Fotó: Dr. Dobránszki Judit)

Az in vitro növényt vagy mikrogumót még további két nemzedéken át izolált körülmények között szaporítjuk fel, a visszafertőződést elkerülendő. Az üvegházi körülmények között letermesztett in vitro szaporítóanyagokról kapjuk meg az első in vivo gumónemzedéket, az ún. primer gumót. Ezt fóliában vagy izolátorháló alatt továbbszaporítva kapjuk meg a második gumónemzedéket, az ún. szekunder gumót. A szekunder gumókat már szántóföldi körülmények között szaporítjuk tovább, szigorú technológiai előírások betartásával, ami lehetővé teszi a jó minőségü vetőgumó előállítását (Magyarné és Dobránszki, 1997).

\subsubsection{Az alma jelentősége és mikroszaporításának lehetősége}

Az alma Magyarország gyümölcstermesztésének legjelentősebb gyümölcsfaja, az összes gyümölcstermésnek több mint 60\%-át adja. Az utóbbi időszakban a termés jelentősen visszaesett, kb. 35 ezer hektáron a 2006-2010-es évek átlagában évente átlagosan 470 ezer tonna alma termett. Ezen túlmenően a két fő felhasználási forma - léalma, étkezési alma - aránya is kedvezőtlen. A 2000-es évek elején a termés több mint 80\%-át dolgozta fel az élelmiszeripar, de nem elsősorban nagy hozzáadott értékü termékek, hanem sürítmény és félkész termékek előállítására (Tóth, 2013b).

Míg a 80-as években az 1,2 millió tonna körüli termés sem volt ritka, addig mára a 600 ezer tonna elérése is nagy eredmény. 2011-ben az országban összesen 235000 tonna termett 35689 ha területen. 2012-ben 614000 tonna almát sikerült betakarítani 26067 ha-ról (KSH, 2012).

Jelenleg a hazai almafogyasztás kb. 15-20 kg/fö/év, ami messze elmarad a 80-as évek 30 $\mathrm{kg} /$ fö/év körüli szintjétől. Ennek több oka is van, többek között az életszínvonal romlása, a 
fizetőképes kereslet csökkenése és a déli gyümölcsök térnyerése a magyar piacon, melyek egyértelmü helyettesítő termékei és vetélytársai az almának.

A gyümölcstermő fás növény fajok, beleértve az almát is, szaporítása vegetatív (ivartalan) úton történik, mert a fajtaazonosság csak így tartható meg. A szaporítóanyag előállítás elsődleges feladata a genetikai tulajdonságok megőrzése mellett a kórokozómentesség biztosítása. Az oltványok elöállításához alany és nemes törzsültetvényekröl származó hajtásokat/rügyeket használnak, azonban az idősebb törzsültetvények a több évig tartó termesztés alatt jelentős mértékben fertőződtek kórokozókkal, elsősorban vírusokkal. Szükségessé vált tehát a már meglévő, termesztésbe vont fajták vírusmentesítése (általában hőkezeléssel) és a vírusmentesített alapanyagok mikroszaporítással történő felszaporítása új, megfelelő egészségi állapotú törzsültetvények létrehozásához (Dobránszki, 2005). Az új termesztési módszerek, felhasználási igények, illetve a környezeti változások sürgetik az újabb fajták kifejlesztését, valamint az új fajták gyors felszaporítását. Ennek megvalósításában nagy szerepe van a kórokozó-mentesített alapanyagok in vitro klónozással, üzemi méretekben történő felszaporításának.

Az alma mikroszaporítása két lépcsőben történik, a felszaporítási ciklusban csak a hajtások sokszorozódása történik a kívánt mennyiség eléréséig (ez az ún. hajtássokszorozási vagy proliferációs szakasz). Ezt követi az in vitro hajtások gyökérindukciós szakasza (Zimmerman és Broome 1980). Az irodalmi adatok (James és Thurbon, 1979, Karhu, 1995) erős genotípus függést mutatnak mind a hajtássokszorozási, mind a gyökeresítési fázisban, ezért egy-egy módszer általában nem adaptálható a fajták széles körére. Az in vitro körülményeket, a táptalaj összetételét mindig az adott genotípusra kell optimalizálni.

Almánál az in vitro tenyészetek létrehozása merisztéma vagy hajtáscsúcsizolálással történhet. Indításkor az explantátumok barnulása az egyik leggyakrabban jelentkező probléma, mely végül akár az explantátum elhalását is eredményezheti. A jelenség oka a polifenolok nagy mennyiségben történő képződése, mely valószínüleg egyfajta - a szövetek megsebzése által indukált - védekezési reakció. Az explantátum barnulás miatti elhalását megakadályozhatjuk, ha az explantátumot gyakran áthelyezzük új táptalajra, vagy különböző adalékanyagokat alkalmazhatunk a táptalajban pl. aktív szén, polivinil-pirrolidon stb. (Jámborné, 2005).

A hajtássokszorozási szakaszban az újonnan fejlődő hajtások számát, hosszát és fiziológiai állapotát számos tényező befolyásolja. Ezek közül a legfontosabbak a genotípus, a táptalaj alkotók (sók, szénhidrátok, növekedési regulátorok típusa és koncentrációja), megvilágítási körülmények stb. (Dobránszki és Teixeira da Silva, 2010).

Az alma mikroszaporításában használt táptalaj leggyakrabban az MS (Murashige and Skoog, 1962) táptalaj, mely szénhidrát forrásként többnyire szacharózt tartalmaz. A szénhidrát típusa jelentősen befolyásolja a hajtásproliferáció sikerét, és a különböző genotípusok igénye eltérő 
lehet, például a 'McIntosh' fajta esetében jelentősen nőtt a hajtások száma, amikor a táptalaj szacharóz helyett szorbitolt tartalmazott (Karhu, 1995). Az alma mikroszaporítás sikerét jelentős mértékben meghatározza az in vitro hajtásokon végzett gyökérindukció, majd a járulékos gyökerek kifejlődése után a hajtások sikeres akklimatizációja (Bolar et al., 1998).

A hatékony gyökeresítési és akklimatizációs technológiák kidolgozásának jelentős szerepe van a transzgénikus vonalak elöállításában is. A legtöbb nemes és alanyfajta gyökeresedése problémát jelent mind in vivo mind in vitro körülmények között, azonban számos genotípus esetén sikeres gyökeresítési és akklimatizációs eredményekről számoltak be (Dobránszki és Teixeira da Silva, 2010). A különböző genotípusok igénye a gyökeresítés körülményeire igen eltérőek, fontos szerepe van a sötét környezetnek, valamint az alkalmazott szénhidrát mennyiségének, típusának (Yepes és Aldwinckle, 1994; Welander, 1983; Bahmani et al., 2009), azonban a gyökérindukciós fázisban legjelentősebb tényezőnek a táptalajhoz adagolt auxin bizonyult (James, 1983).

További nehézséget jelent a gyökeres in vitro hajtások akklimatizációja, mely fázist célszerü a hosszúnappalos időszakban végezni (legmegfelelőbb a tavasz), hogy a növények a téli időszak beköszöntéig kellőképpen meg tudjanak erösödni, és szabadföldi körülmények között át tudjanak telelni (Dobránszki, 2005).

Az alma in vitro szövettenyésztésnek nem csak a fajtafenntartásban, hanem a nemesítésben is jelentős szerepe van (Korban és Chen, 1992). Az in vitro tenyészeteket sikeresen használhatjuk karantén kórokozók tesztelésére is, mivel steril körülmények között, biztonságosan folynak a mesterséges fertőzések és megfigyelések, a kísérleti anyag a vizsgálatok után könnyebben megsemmisíthető, a kórokozó kiszabadulásának nincs veszélye. 


\subsection{A vizsgált baktériumfajok}

2.2.1. A burgonyát károsító baktériumfajok, az előidézett betegségek és a védekezési lehetőségek

A Pectobacterium fajok (Pectobacterium carotovorum subsp. carotovorum (Pcc) és a Pectobacterium carotovorum subsp. atrosepticum (Pca)), valamint a Dickeya fajok (Dickeya dadantii $(D d)$ ) által okozott betegségek: a fekete szártőrothadás vagy feketelábúság, a szár nedves rothadása és a gumók nedves rothadása (Pérombelon, 2002) mind a vetőburgonya, de az étkezési burgonya termesztése során is igen jelentős károkat okozhatnak.

Amíg a $P c c$-nak számtalan gazdanövénye van világszerte, addig a $P c a$ csak a burgonyán károsít föleg a mérsékelt övi régióban. Ezzel szemben a Dickeya fajok, bár korlátozott számú gazdanövényen élnek meg, előfordulnak mind a mérsékelt, mind a szubtrópusi és trópusi régiókban (Toth et al., 2011). Mind a három baktériumfaj okozhat lágyrothadást, de a fekete szártőrothadás tünetét nem mindig tulajdonították mindhárom baktériumfajnak. Egy ideig úgy gondolták, hogy csak a Pca okoz fekete szártőrothadást a mérsékelt éghajlati övben és a Dickeya fajok pedig a melegebb régiókban (Pérombelon és Salmond, 1995). Később azonban a Pcc-ról is kimutatták, hogy a burgonyát fertőzve tipikus feketelábúság tüneteket okoz (de Haan et al., 2008). Mindez Európában a nyári időszak hőmérséklet változásainak is köszönhető, vagy pedig felveti annak a lehetőségét, hogy adaptálódott formák alakulhattak ki. Figyelemre méltó, hogy a forró nyarairól is ismert Colorádóban és Arizonában (USA) már régóta megfigyelték, hogy a Pcc is okozhat feketelábúságot (Molina és Harrison, 1977).

A Dickeya fajokról régóta közismert, hogy fekete szártőrothadást okoznak a trópusi és szubtrópusi területeken, viszont Nyugat-Európában csak 1988-ban izoláltak Dickeya fajokat feketelábúság tüneteit mutató növényekről (Janse and Russien, 1988). Magyarországra az 1980as évek közepén került be import vetőburgonyával. A Dickeya fajok kártételéről szóló hírek száma az elmúlt évtizedekben megnövekedett, ami részben annak köszönhető, hogy a korábbi burgonyát károsító Dickeya fajokhoz képest (Dickeya dianthicola, Dickeya dadantii) egy új fajt azonosítottak, melyet a szakirodalom Dickeya solani-ként említ.

A közelmúltban a Pectobacterium carotovorum két új alfaját írták le, mely szártőrothadást okoz. A Pectobacterium carotovorum subsp. brasiliensis egy agresszív baktérium, mely a Braziliában és Dél-Afrikában előforduló szártőrothadás jelentős részéért tehető felelőssé (Duarte et al., 2004; van der Merwe et al., 2010). A másik alfaj a Pectobacterium carotovorum subsp. wasabiae, melyet a burgonya új kórokozójaként írtak le Új-Zélandon, de később a japán torma lágyrothadásával is összefüggésbe hozták (Garden et al., 2003; Pitman et al., 2010). 
Mind a Pectobacterium, mind a Dickeya fajok könnyen tenyészthetők, és polipektátot tartalmazó szelektív táptalajon könnyen felismerhetök (Stewarts MacConkey-pektát táptalaj, Cuppels és Kelman kristályibolya-pektát (CVP) táptalaj) ugyanis mély „árkokat”, „krátereket” okoznak. Eozin-metilénkék agaron (Holt-Harris és Teague, 1916) pedig aranyszínü telepeket fejlesztenek (2. ábra).
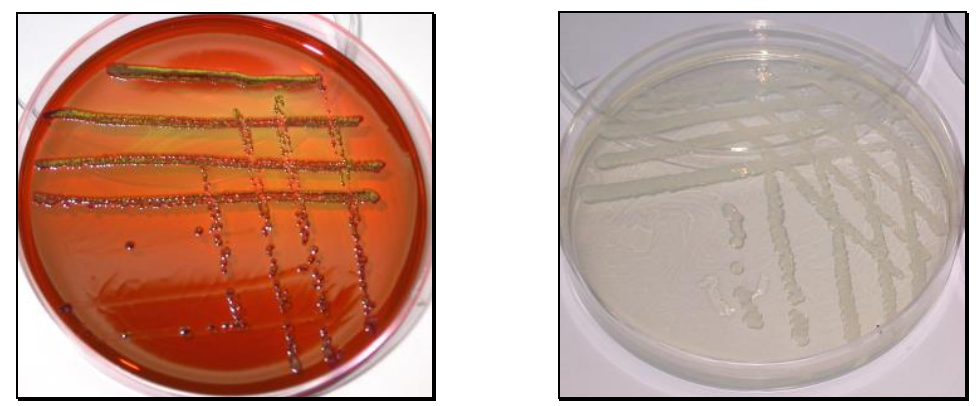

2. ábra. Pectobacterium carotovorum subsp. carotovorum telepek eozin-metilénkék agaron, illetve Nutrient agaron

A Pcc pálcika-alakú, Gram-negatív, 0,7 x 1,5 $\mu \mathrm{m}$ méretü, peritrich flagellával rendelkező baktérium. Nem spóraképző és fakultatív anaerob (Hauben et al., 2005). A Pca maltózból és $\alpha$ metil-glükozidból savakat képez, a szacharózt redukálja, tápagaron $36{ }^{\circ} \mathrm{C}$ felett nem nö. A Pcc tipikus törzsei $\alpha$-metil-glükozidból nem képeznek savakat és a szacharózt sem redukálják, tápagaron $36^{\circ} \mathrm{C}$ felett szintén nem nőnek.

A baktérium a gazdanövény sejtközötti járataiba behatolva sokszorozódik és pektolítikus enzimeket (pektin-metil-észteráz, depolimeráz és pektin-liáz) termel, ezálta a középlemez feloldásával fellazítja a szöveti szerkezetet (lágyrothadás). A pektolítikus enzimek mellett kisebb mértékben cellulózbontó enzimek is termelődnek, amelyek a sejtfalban lévő cellulózt roncsolják. A sejtek víztartalma a sejtközötti járatokba diffundál, a sejtek halálát okozva. A baktérium a keményítőt csak a rothadás késői stádiumában bontja le.

A kórokozó mindenekelőtt fertőzött vetőgumóval terjed. Fertőzött vetőgumó elültetése után a tenyészidő bármely szakaszában! - nagyszámú baktériumsejt kerül a talajba, ahonnan fertőződik a gazdanövény földfeletti része is. A tenyészidőszakban a baktérium gyorsan szaporodik a gazdanövény vagy bizonyos gyomok rizoszférájában. A talajban általában rövidebb-hosszabb ideig képes fennmaradni, de a fertőzött szárban, vagy gumóban a telet is átvészeli. A talajban való túlélése a környezeti tényezőktől függ, hüvös, nedves körülmények között hosszabb ideig is életképes marad. A baktérium a talajvízbe kerülve a szomszédos területek növényeinek fejlődő gumóit is képes megfertőzni. A fertőzés mértéke szintén 
nagymértékben függ a környezeti feltételektől. A baktérium behatolhat a lenticellákon, a gumóhéj repedésein, vagy a betakarításkor keletkező gumósérüléseken keresztül. Csekély fertőzés esetén a gumóban a kórokozó az egész tárolási periódust képes túlélni, viszont az ültetés után a baktérium gyorsan terjed, és a kórfolyamat, azaz a gumók lágy rothadása folyamatosan ismétlődik, kiegészülve azzal, hogy a gumók mosására használt vízzel is gyorsan terjed a baktérium.

A betegség fellépésének mértéke az időjárástól függ. Hazai viszonyok között a baktériumok nem telelnek át a talajban. Fennmaradásuk a talajban korlátozott, 1 hét és 6 hónap közé tehető attól függően, hogy milyenek a környezeti feltételek pl. a talajnedvesség, a hőmérséklet és a pH stb. Az életben maradásuk meghosszabbodhat, ha növényanyaggal kerülnek a talajba, de ekkor sem képesek a vetésforgóban 3-8 évnél tovább fennmaradni (Anilkumar és Chakravarti, 1970; Rangarajan és Chakravarti, 1970; Lim, 1975; Pérombelon és Hyman, 1988). Bőséges csapadék, így a nagy talajnedvesség és viszonylag alacsony hőmérséklet $\left(18-19{ }^{\circ} \mathrm{C}\right)$ a betegség kifejlődésének kedvez, míg a meleg, száraz idő a betegség kialakulását és terjedését akadályozza, a baktérium a talajban kisebb távolságokra képes eljutni. A sürü, tömött és nedves lombozat elösegíti a szár fertőződését. Ha hüvös, nedves időszakban ültetünk, s azt a kihajtás időszakában magas hömérséklet követi, ez mindenképpen a betegség megjelenésének kedvez, mivel magas talajhőmérsékleten gyakori, hogy a hajtások a felszínre kerülés előtt elrothadnak. Ezért meleg és nedves körülmények között a fekete szártőrothadás okozta veszteség meghaladhatja a hüvös klímán okozott kártétel mértékét is. A Pcc tipikus fekete szártőrothadásos tüneteket okozhat magas $\left(30-35^{\circ} \mathrm{C}\right)$ talajhőmérséklet esetén.

Ma már általánosan elfogadott, hogy a fekete szártőrothadás fö forrása a látensen fertőzött anyagumó (Pérombelon, 1974). Amikor az anyagumó elrothad, a baktériumok kikerülnek a talajba, és a talajvíz révén kapcsolatba kerülnek a szomszédos gumókkal. Czajkowski et al. (2010) kimutatták, hogy a baktériumok a talajban a burgonyagyökereken megtelepednek, majd az edénynyaláb rendszeren keresztül kerülnek a gumókba és onnan a szárba, de nem feltétlenül okoznak tünetet, hanem látens formában túlélhetnek.

A levegőnek is fontos szerepe van a baktérium terjedésében (Graham, 1976; Harrison et al., 1987; Pérombelon, 1992). Levegőmintákat vizsgáltak Skóciában és kimutatták, hogy mind Pccot, mind pedig Pca-t tartalmaztak a minták esősebb napokon több, míg szárazabb napokon kevesebb számban. A fertőzött növényekről a kórokozó a levegőbe kerül, és a rovarok (pl. drótféreg) révén nagy távolságokra is képesek eljutni. Rovarfajokon kívül az esőcseppekkel, öntözéssel, művelési szerszámokkal szintén terjed a kórokozó. Felszíni vizekben az USA-ban és Skóciában is találtak Pcc-t, valamint kisebb mennyiségben Pca-t (McCarter-Zorner et al; 1984, Harrison et al., 1987). Az utóbbi időben, még le nem írt Dickeya fajokat találtak folyóvízben és 
ezzel egyidejüleg fertőzött vetőgumókra bukkantak Finnországban (Laurila et al., 2008, 2010). Valószínüleg az öntözési célokra használt felszíni vizek szintén forrásai lehetnek a kórokozónak, illetve újonnan megjelenő variánsainak. A gumódarabolás is nagymértékben elősegíti a baktérium terjedését.

Gumók lágyrothadása. Azok a körülmények, melyek kedveznek a szártőrothadás kialakulásának, szintén kedveznek a gumók lágyrothadásának is (Pérombelon, 1992). A kórfolyamat gyorsabb a nagyobb nedvességtartalmú növényi szövetekben. A fertőzött gumók nedvesrothadását elősegíti, ha a gumó éretlen, a gumón sebzés van, a gumót napsugárzás éri, a magasabb hőmérséklet, a nagy páratartalom és az oxigén hiánya. $20-25{ }^{\circ} \mathrm{C}$ talajhőmérséklet felett betakarított gumók fogékonysága jelentősen nő. A rothadási folyamatnak a $10{ }^{\circ} \mathrm{C}$ feletti hőmérséklet kedvez, de az optimális hőmérséklet 25-30 ${ }^{\circ} \mathrm{C}$, mely egyben laboratóriumi körülmények között is az optimális hőmérsékleti tartomány a patogén tenyésztésére. Magas hőmérsékleten $\left(30^{\circ} \mathrm{C}\right.$ felett) jelentős a másodlagosan fertőző kórokozó fajok (Pseudomonas, Bacillus, Clostridium sp.) kártétele is.

A kórokozó baktérium szaporodásához nincs szükség oxigénre, így az oxigénhiányos környezet kedvez a gumó nedves rothadás betegség kifejlődésének. Ha a gumókat a talajban, vagy a tárolás során vékony nedvességfilm borítja (nedves környezetben ez könnyen előfordul), a szövetek gyorsan oxigénhiányossá válnak (Pérombelon et al., 1989). Oxigénhiányos állapot alakulhat ki a talaj elárasztása (nem megfelelő öntözés, illetve rossz vízgazdálkodású talaj), a gumók mosása, vagy a gumóknak fungicid hatású növényvédőszerrel való bepermetezése esetén is. A gumó természetes védekezési rendszerét az oxigénhiány leblokkolja, a nedves rothadást okozó baktériumfajokat azonban nem befolyásolja hátrányosan. Fokozott nitrogénellátottság mellett a növények fogékonyabbak a baktériumok fertőzéseivel szemben. A túlzott műtrágyaadagok előidézhetnek ,növekedési repedéseket” a gumókban, valamint az átlag feletti csapadék is okozhat gumórepedéseket a védő hatású peridermában, melyek lehetővé teszik a kórokozók behatolását a gazdanövénybe.

A fekete szártőrothadás tünetei (3. ábra) a növényfejlődés bármely szakaszában jelentkezhetnek. Nedves körülmények között a fertőzött növény szárán tintafekete színü elszíneződést figyelhetünk meg, amely a szár alapjáról indul ki és halad felfelé; kiterjedése lehet néhány milliméternyi, de érintheti az egész hajtást is. A fekete elszíneződés felett a szárbél gyakran elrothad, a szállítószövetek elszíneződnek. Abban az esetben viszont, ha a fertőzés száraz körülmények között jön létre, a fertőzött növények satnya növekedésűek lesznek. A lombozat klorotikussá válik és a levélkék széle felfelé bepödrődik. Kezdetben a levélkék, majd 
később az egész növény hervad, és lassú hanyatlásnak indul, végül elpusztul (Pérombelon és Kelman, 1980).

Késő nyáron, kifejezetten esős körülmények között előfordulhat, hogy a szár rothadása a növény felső részéről indul és halad lefelé, de ilyen tüneteket csak a $P c c$ esetén figyeltek meg (Pérombelon és Kelman, 1980).
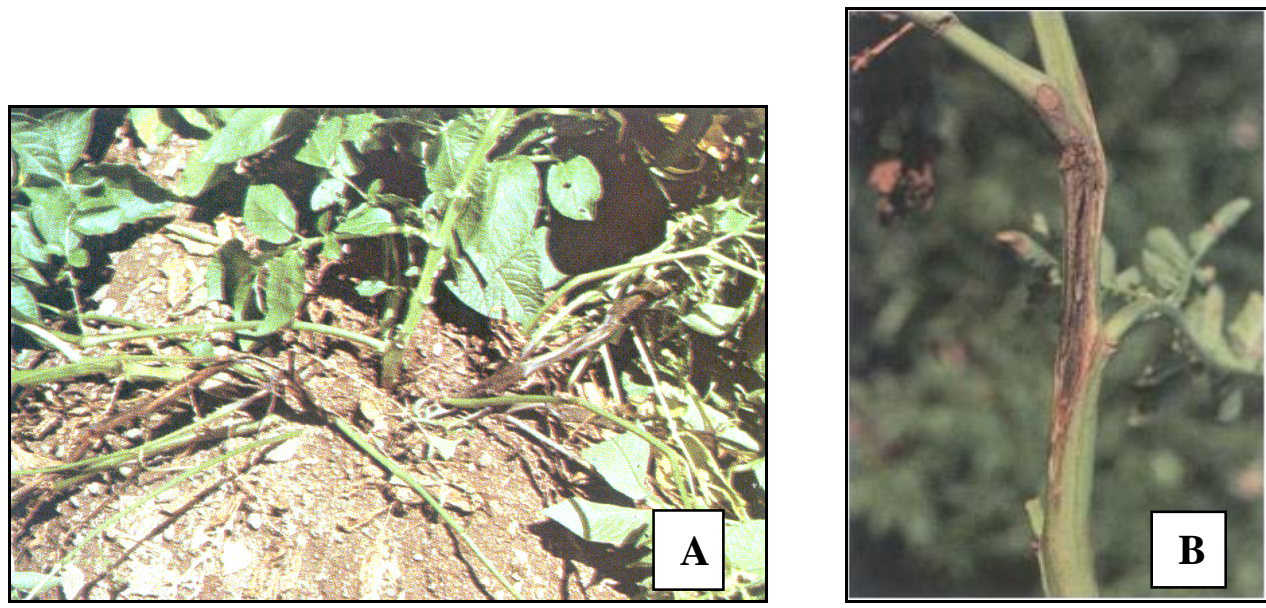

3. ábra. A fekete szártőrothadás tünetei burgonyahajtásokon

(Forrás: A: Harrison, M. D. In: Hooker, W. J. (ed) 1990. Compendium of Potato Diseases. APS PRESS, USA; B: Rowe, R. C. (ed) 1993. Potato Health Management, APS PRESS, USA)

Fertőzött vetőgumó esetén néha már a kelés után is láthatók a növésben visszamaradt, sárguló, fertőzött tövek. Gyakori, hogy a hajtások a föld felszínéig sem jutnak el, hanem már előbb elhalnak. Nagy talajnedvesség esetén sokszor a beteg gumó ki sem hajt, hanem elrothad.

A szár és a levél vagy sebzésen keresztül, vagy természetes nyílásokon keresztül fertőződhet az öntözővíz, aeroszolos kezelés, vagy rovarok által. A fertőzés a szárban és levélnyélben lefelé és felfelé is terjedhet, így a szárrothadás olyan növényeken is kialakulhat, melyek anyagumója egészséges volt. Nedves időben a rothadás nedves, nyálkás és a növény nagy részére kiterjed. Száraz időben a fertőzött szövetek kiszáradnak, összezsugorodnak, és a tünetek gyakran csak a szár alsó részén figyelhetők meg. A fertőzött szár (3. ábra) sokszor világos vagy középbarna, a tintafekete elszíneződés nem mindig jellemző.

A fertőzött növényen fejlődő gumók a betegség különböző stádiumainak tüneteit mutathatják a sztólóvégen megfigyelhető enyhe edénynyaláb elszíneződéstől a gumók teljes elrothadásáig. A fertőzött gumókban a sztóló felőli végből kiindulva a bél és a medulláris régió nedves rothadása figyelhető meg, jellegzetes tünete a gumó sztólós részében bemélyedő megsötétedett folt (4. ábra). 

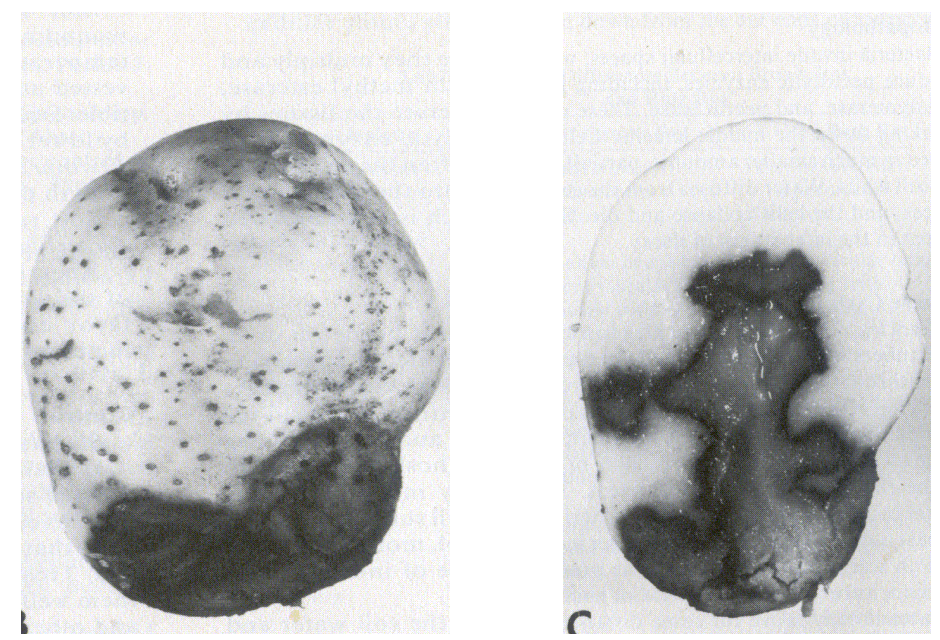

4. ábra. A fekete szártőrothadás tünetei gumókon

(Forrás: Hooker, W. J. (ed) 1990. Compendium of Potato Diseases. APS PRESS, USA)

Gumók lágyrothadása. A gumók a betakarítás előtt, vagy a tárolás során fertőződhetnek a lenticellákon (paraszemölcsökön), a gumósérüléseken, vagy a fertőzött anyanövénytől a gumó sztóló felöli végén keresztül. A lenticellákon keresztül megfertőződött gumókon a lenticellák körül kissé beesett sárgásbarna, körkörös, vizenyős, 0,3-0,6 mm átmérőjü foltok figyelhetök meg. Száraz körülmények között ezek a területek kiszáradnak, keménnyé válnak. Ha a kórokozó sebzésen keresztül hatolt be, szabálytalan alakú, beesett, sötétbarna foltok alakulnak ki. A lágy rothadásos szövetek nedvesek, krémszínủek, lágy, enyhén kásás konzisztenciájúak. A fertőzött szövetek élesen elválnak az egészséges szövetektől. A sebek szélén gyakran figyelhető meg barna vagy fekete pigmentáció (5. ábra). A rothadó szövetek kezdetben szagtalanok. Később, ha a fertőzött szövetekbe másodlagosan egyéb baktériumok hatolnak be, kellemetlen szagúvá, nyálkás, nyúlós konzisztenciájúvá válnak.

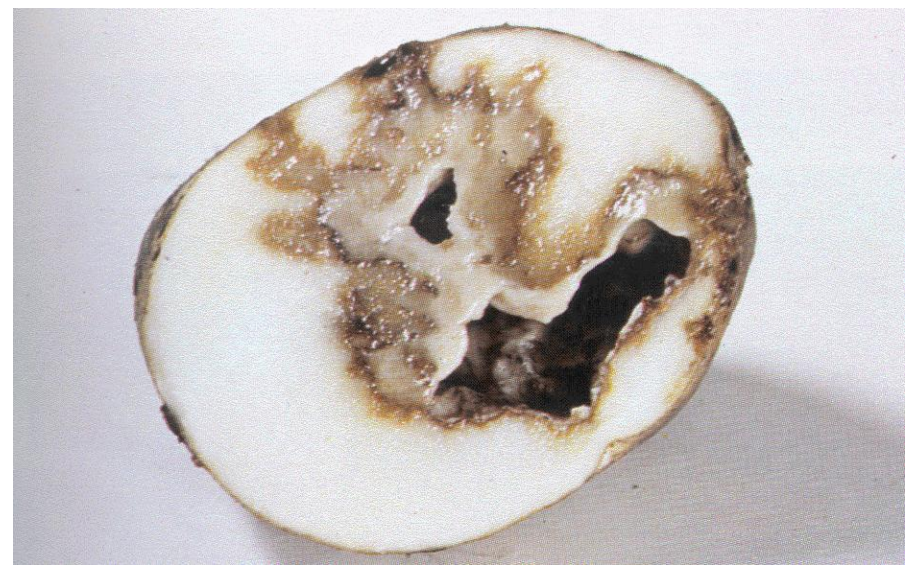

5. ábra. A gumók lágyrothadásának tünetei

(Forrás: Huguelet, J. E. In: Hooker, W. J. (ed) 1990. Compendium of Potato Diseases. APS PRESS, USA) 
A Pectobacterium, illetve Dickeya fajok meghatározása a tünetek alapján nem lehetséges, ehhez laboratóriumi vizsgálatok szükségesek (biokémiai, szerológiai, illetve molekuláris biológiai módszerek stb.).

Mivel a kórokozók a paraszemölcsökben vagy az edénynyaláb rendszerben helyezkednek el, ezért a betegség elleni védekezés nem vagy nehezen megvalósítható növényvédő szerekkel. Mindenképpen integrált szemléletre van szükség; legfontosabb a megelőzés.

A kereskedelmi forgalomban lévő burgonya fajták fogékonysága a Pectobacterium és Dickeya fajokkal szemben eltérö. Néhány fajta részleges rezisztenciát hordozhat, de jelenleg teljesen ellenálló fajták nincsenek köztermesztésben. Tzeng et al. (1990) szerint azok a kutatások, melyeknek a célja a rezisztens burgonyafajta létrehozása volt, azért voltak csak részben sikeresek, mert a használt nemesítési alapanyag viszonylag szűk diverzitású, ráadásul nem is kapott megfelelő hangsúlyt az ez irányú nemesítés más kórokozókkal szembeni vagy egyéb agronómiai tulajdonságokra való nemesítésekkel szemben. További problémát jelenthet, hogy a vizsgálati módszerek sem egységesek. A fajták rangsora a lágyrothadással szembeni rezisztenciájukat tekintve függ attól, hogy milyen az inokulálási módszer, továbbá szántóföldi vagy laboratóriumi vizsgálatokról van-e szó (Bain és Pérombelon, 1988; Lojkowska és Kelman, 1994). Allefs et al. (1995) szerint kizárólag a szántóföldi kísérletek azok, melyek megbízható eredményeket adnak.

A burgonya rezisztencianemesítésében fontos szerepet tölthetnek be a vad Solanum fajok, mint génforrások. Több mint $200 \mathrm{vad}$ Solanum faj van a különböző amerikai, és európai génbanki gyüjteményekben, melyek között vannak a Pectobacterium és Dickeya fajokkal szemben ellenállók is (Hijmans és Spooner, 2001). Ráadásul ezen vad fajok többsége diploid, mely megkönnyíti a hibridizációt a Solanum tuberosummal, nem úgy, mint a tetraploid Solanum fajok (Watanabe et al., 1994). Ide tartoznak a S. canasence, a S. tarijense és a S. tuberosum subsp. andigena. Ez utóbbiról úgy gondolják, hogy a közönséges burgonya közvetlen leszármazottja és magas szintű rezisztenciát hordoz, mind a Pectobacterium, mind a Dickeya fajokkal szemben (Hidalgo és Echandi, 1982). A hibridek közül a S. tuberosum és a S. phureja gyakran használatos a nemesítési programokban az ellenállóságuk miatt, a terméshozamuk viszont alacsony (Rousselle-Bourgeois és Priou, 1995). Amikor a vad Solanum fajok közül a $S$. commersonniit - mely közismerten ellenálló a faggyal, fonálférgekkel és gombákkal szemben keresztezik S. tuberosummal az utódok magasfokú rezisztenciát mutatnak a Pectobacterium és a Dickeya fajokkal szemben is, mind az üvegházi, mind a szántóföldi kísérletek során (Laferriere et al., 1999). A kereskedelemben lévő burgonyafajtáknál ellenállóbb utódokat kaptak, ha $S$. tuberosum hibrideket kereszteztek $S$. chacoense, S. sparsipillum vagy $S$. multidissectum fajokkal. Itt a problémát a magasabb glikoalkaloid-tartalom jelentette, mely mérgező mind az ember, mind 
az állatokra nézve (Carputo et al., 1997). A Solanum brevidens egy diploid Solanum faj, mely gumót nem hoz, de néhány burgonyavírussal és a faggyal szemben ellenálló. A S. tuberosum és a S. brevidens szomatikus hibridjei már magasszintű rezisztenciát mutattak a Pectobacterium és a Dickeya fajokkal szemben, és ez a tulajdonságuk átvihető volt az $F_{1}$ és $F_{2}$ nemzedékbe is, valamint visszakeresztezhető S. tuberosum fajtákkal (Zimnoch-Guzowska és Lojkowska, 1993; Zimnoch-Guzowska et al., 1999). Mindez azt bizonyítja, hogy viszonylag távoli rokonságban álló Solanum fajokat is be lehet vonni a burgonya rezisztencianemesítésébe (Austin et al.,1988).

A jó minőségü burgonya tárolásának fontos kritériuma az alacsony hőmérséklet $\left(\mathrm{kb} .5^{\circ} \mathrm{C}\right)$ és a megfelelő szellőzés. A mérsékelt égövi országokban ez kisebb gondot okoz, mint a trópusi vagy szubtrópusi országokban, ahol a tárolás komoly és valós probléma. A magas külső hőmérséklet a nem szabályozott tárolás során nemcsak a gumók nyugalmi állapotát befolyásolja, hanem a kártevők és a kórokozók szaporodását is elösegíti, ezáltal különösen a lágyrothadást okozó baktériumok okoznak súlyos veszteségeket. A gumók fizikai kezelése a gumó felületén lévő baktériumok széles körére hatással lehet. Hátránya, hogy a jótékony mikroorganizmusokra is károsan hathat és az egészséges gumó fizikai állapotát is kedvezőtlenül befolyásolhatja. A lágyrothadás ellen használt fizikai kezelések között több módszert említenék meg. Ezek a forró víz, a gőz (Robinson és Foster, 1987; Shirsat et al., 1991), a száraz meleg levegő (Bartz és Kelman, 1985), valamint az UV-sugárzás és a napsugárzás (Ranganna et al., 1997; Bdliya és Haruna, 2007).

Lágyrothadást okozó baktériumok ellen meleg vizes kezelést 1983-ban végeztek először (Mackay és Shipton, 1983). 10 percig $55^{\circ} \mathrm{C}$-os vízben áztatták a természetes úton fertőződött burgonyagumókat, és a felületükön nem tudtak sem $P c c$-t, sem $P c a$-t kimutatni. Szántóföldön sem tudtak fekete szártőrothadást megfigyelni a kezelt gumókból fejlődött növényeken. Hasonló eredményeket kapott Wale és Robinson (1986) és Shirsat et al. (1991), akik kimutatták, hogy 45 ${ }^{\circ} \mathrm{C}$-os vízben 30 percig vagy $56{ }^{\circ} \mathrm{C}$-os vízben 5 percig kezelt gumókon szignifikánsan csökkent a periderma és a lenticellák kórokozók okozta szennyezettsége, ezáltal a szártőrothadás esélye is csökkent a szántóföldön. Azonban ha a megfelelő szárítás elmarad, a túlélő baktériumok gyorsan felszaporodhatnak, és gyors rothadást idézhetnek elő. A kezelés hátránya, hogy egyéb gombás fertőzések kialakulását is elősegítheti (Dashwood et al., 1991).

A gőzt is vizsgálták a meleg vizes kezelés alternatívájaként azért, hogy a gumó felületén jelenlévő $P c c$-t és $P c a$-t eltávolítsák. Ezzel a kezeléssel a 26-59\%-os fertőzöttséget 1-3\%-ra sikerült csökkenteni (Afek és Orenstein, 2002). Bartz és Kelman (1985) is arról számolt be, hogy a gumófelületen lévő, külső $P c c$-t sikerült gyéríteni $50{ }^{\circ} \mathrm{C}$-os száraz, meleg levegő átfuvatásával. Ez a kezelés azonban kevésbé hatékony a meleg vizeshez képest, mivel hosszabb kezelési időre van szükség, amely kedvezőtlenül befolyásolhatja a gumók fiziológiai állapotát. 
Ranganna et al. (1997) tesztelték az UV sugárzás hatékonyságát $P c c$-val fertőzött gumókon. A lágyrothadást okozó baktériumokat már egy viszonylag alacsony $\left(15 \mathrm{kJm}^{-2}\right)$ UV sugárzás is elpusztítja. A vákuuminfiltrációval fertőzött gumókat közvetlen napfénynek tették ki 3 órán keresztül. A fertőzött gumókon tünetek egyáltalán nem alakultak ki, ami valószínüleg annak köszönhető, hogy a közvetlen napfény hatására a gumó felszínének hőmérséklete megemelkedett, amely kedvezőtlenül befolyásolta a baktériumok szaporodását.

A fizikai kezelések előnye, hogy vegyszermentesek, viszont csak a gumók felületén jelenlévő kórokozók gyérítésére alkalmazhatók. A szövetek belsejében lévő patogének ellen nem hatásosak. Széleskörű alkalmazásuk nehézkes és a működési költségek is jelentősek lehetnek.

A kémiai védekezés története során elsőként kell megemlítenünk az antibiotikumokat, kiemelve a sztreptomicint és származékait. Hosszú időn keresztül ezt az antibiotikumot tartották ígéretes lehetőségnek a védekezés szempontjából. Bonde és de Souza (1954) a vetőgumókat sztreptomicin és oxitetraciklin-hipoklorit keverékébe vagy sztreptomicin és higanyvegyületek keverékébe mártotta ültetés előtt, mellyel csökkentették a szártőrothadás előfordulását szántóföldön, illetve a gumók lágyrothadását a tárolókban. Hasonló eredményeket kapott Wyatt és Lund (1981), valamint Bartz (1999), amikor kasugamicint vagy virginiamicint használtak sztreptomicin helyett. Bár a kísérleti eredmények ígéretesek voltak, humángyógyászati szempontból nem kívánatos az antibiotikumok használata. Fennáll az antibiotikummal szembeni rezisztencia kialakulásának veszélye mind az emberekben, mind az állatokban.

$\mathrm{Az}$ antibiotikumok alternatívájaként teszteltek különböző baktericideket elsősorban laboratóriumi kísérletekben. Szerves vegyületek közül a hidroxi-kinolint és az 5-nitro-8-hidroxikinolint találták hatékonynak lágyrothadást okozó baktériumok ellen, sérült burgonyagumókon (Harris, 1979). Hasonló eredményeket kapott Bartz és Kelman (1986) a klórtartalmú vegyületekkel. Kísérletükben bronopolt (2-bróm-2-nitropropán-1,3-diol) és egy szintetikus baktericidet, a 7-klór-1-metil-6-fluor-1,4-dihidro-4-oxo-3-kinolin karboxilsavat teszteltek. Mills et al. (2006) kimutatták, hogy bizonyos szerves és szervetlen sók, mint például az alumíniumacetát, a nátrium-metabiszulfát, a nátrium benzoát, a timsó, a kálium-szorbát, a kálciumpropionát, a nátrium-hipoklorit, a nátrium-bikarbonát, az aluminium-klorid és a réz-szulfát képes gátolni a $P c a$ és a $P c c$ szaporodását in vitro körülmények között. A szerves és szervetlen sók hatása annak tulajdonítható, hogy a sókban lévő kationok gátolják a baktérium sejtmembránjában lévő fehérjék funkcióit, az anionok pedig befolyásolják a környezet pH-ját (Mills et al., 2006). Kamysz et al. (2005) eredményei szerint egy szintetikus peptid, a Camel (cekropin-melittin hibrid peptid) sokkal nagyobb védelmet biztosít a burgonygumók számára a Pca és a Dickeya fajokkal szemben, mint a sztreptomicin. 
A kémiai kezelések alkalmazása azért nem egyszerü, mert egyrészt a vegyszernek kapcsolatba kell lépnie a baktériumokkal, melyek általában jól védett helyen vannak a gumó szövetében, a lenticellákban, sebzésekben és az edénynyaláb rendszerben. Egy gáznemü baktériumölő alkalmazása lehet sikeres ilyen szempontból, de könnyen előfordulhat, hogy fitotoxikus hatást vált ki, ahogyan Eckert és Ogawa (1988) is leírta a jelenséget klórgáz esetén. Az egyik lehetőség talán az lenne, hogy a frissen betakarított gumók mosásakor az utolsó öblítés egy hipokloritos oldattal történne, mellyel a felületi fertőzöttséget lehet csökkenteni. Ezt követné egy szárítás, mellyel minimalizálni lehetne a tárolás során fellépő rothadást.

A biológiai védekezés lehetőségeit elsősorban in vitro körülmények között tesztelték, ezeket a következőkben szeretném röviden összefoglalni. A talajban élő fluoreszkáló és nem fluoreszkáló Pseudomonas fajokról mutatták ki, hogy potenciális antagonistái a szártőrothadást és lágyrothadást okozó baktériumoknak (Kastelein et al., 1999). Ezek a baktériumfajok a burgonya rizoszférájában és a talajban élnek (Loper és Henkels, 1999) és másodlagos antibakteriális anyagcseretermékeket állítanak elö, beleértve a sziderofórokat, antibiotikumokat és felületaktív anyagokat (Cronin et al., 1997; Compant et al., 2005). Cronin et al. (1997) használtak olyan Pseudomonas fluorescens törzseket, melyek 2,4-diacetylfloroglucinolt termeltek. Ez az anyagcseretermék képes volt a burgonyagumókon jelenlévő Pca számát redukálni. Abban az esetben, amikor ennek a törzsnek egy mutáns formáját használták, mely nem rendelkezett ezen anyagcseretermék előállításának képességével, hatástalannak bizonyult a $P c a$-val szemben. Mindez azt jelzi, hogy a biológiai védekezés antibiózisnak köszönhetően következett be. Kastelein et al. (1999) szintén arról számoltak be, hogy a burgonyagumók sebzéseinek, repedéseinek védelmére sikeresen használták a Pseudomonas fluorescens törzseket abban az esetben, ha a lágyrothadás okozója a $P c a$ volt.

A tejsav baktériumok közül a Lactobacillus plantarum, a L. acidophilus, a L. buchneri, a Leuconostoc spp. és a Weissella cibaria fajok mutattak antagonista aktivitást a Pcc-val szemben, ami annak köszönhető, hogy hidrogén-peroxidot termelnek és elsavasítják a környezetüket. A tejsavbaktériumok általában nemcsak növénypatogéneket képesek gátolni, például a $L$. plantarum, a W. cibaria és a L. acidophilus a Botrytis cinerea gombafajt is képes gátolni. Ráadásul széles növekedési hőmérséklet spektrummal rendelkeznek $\left(8-45^{\circ} \mathrm{C}\right)$, ami széleskörü alkalmazásukat teszi lehetővé (Trias et al., 2008).

Egy másik lehetőség a biológiai védekezésre a Gram-pozitív Bacillus subtilis, mely széles antibiotikus hatással bír. Nemcsak a humánpatogén vagy opportunista baktériumokkal szemben hatásos, hanem növénykórokozókkal szemben is, úgymint a Pcc, Pca és a Dickeya fajok, Pseudomonas syringea és a Xanthomonas campestris (Sharga és Lyon, 1998). Cladera-Olivera et al. (2006) tanulmányoztak egy Bacillus licheniformis baktériumfajt, mely hatásos volt a Pcc-vel 
szemben. Hatását annak köszönheti, hogy egy baktericidszerü anyagot termel, mely kapcsolódik a Pcc sejtmembrán lipidjeihez és fokozza annak liáztermelését.

Egy másik elméleti lehetőség lehetne a biológiai védekezésre a bakteriofágok használata. A bakteriofágok olyan vírusok, melyek baktériumokat fertőznek. Specifikusak egy adott mikroorganizmusra, biztonságos a használatuk, mert nem fertőzik a melegvérü szervezeteket. Már korábban kimutatták, hogy a bakteriofágok alkalmasak növényi kórokozók, úgymint $E a$, Agrobacterium tumefaciens elleni biológiai védekezésre (Jones et al., 2007). Ugyanakkor használatuk korlátozott, mivel nem mozgékonyak, és a baktériumok gyorsan ellenállóvá válhatnak velük szemben. Csak a fiatal, osztódásban lévő baktériumsejteket képesek fertőzni. Eddig kevés figyelmet fordítottak a bakteriofágok Pectobacterium és Dickeya fajok elleni használatára, de Ravensdale et al. (2007) üvegházi kísérleteiben sikerült fágokkal 50\%-kal csökkenteni a lágyrothadás előfordulását liliomhagymákon $P c c$ fertőzést követően.

A mai napig nincs olyan kereskedelmi készítmény forgalomban, mely alkalmas lenne biológiai védekezésre e kórokozók ellen. Ennek egyik oka a számtalan követelménynek való megfelelési gyakorlat, így a készítmények engedélyeztetése időigényes és roppant költséges.

A baktérium kártételét a higiéniás szabályok maradéktalan betartásával, a szántóföldi és tárolási körülmények megfelelő változtatásával csökkenthetjük minimálisra, mivel sem rezisztens burgonyafajták, sem megfelelő vegyszerek nem állnak jelenleg rendelkezésünkre. A fentiek figyelembevételével a következő megelőző jellegű módszerekkel valósulhat meg a védekezés (Németh, 2013):

* Egészséges, kórokozómentes szaporítóanyag használata. Mindig magas biológiai értékü, fémzárolt gumót ültessünk.

* Vetésforgó alkalmazása. Ha van rá mód, akkor burgonyát olyan kultúra után ne ültessünk, amely a kórokozó jelentős gazdanövényei közé tartozik.

* Különösen a korai ültetéskor mindig használjunk fungicideket. Noha azok nem védenek közvetlenül a nedves rothadástól, megakadályozzák a Fusarium-ok kártételét, így közvetve gátolják az Erwinia fertőzést is.

* Kerüljük azokat a beavatkozásokat, melyek a gumók mechanikai sérülését eredményezik.

* Optimális talajadottságok. A vetőgumó ültetése jó szerkezetủ és jó vízelvezetésű talajba történjen, ha a talajhőmérséklet az ültetési mélységben elérte a $12-13^{\circ} \mathrm{C}$-ot.

* Kerüljük a túlöntözést, hogy ezzel is megelőzzük a baktérium szaporodásának és terjedésének kedvező anaerob viszonyok kialakulását. Az esőztető öntözést előnyben kell részesíteni az árasztásos vagy a barázdás öntözéssel szemben.

* A termesztés higiéniai viszonyai. A fertőzött növényeket azonnal távolítsuk el, hogy a baktérium terjedését, az egészséges egyedek fertőződését megakadályozzuk. A művelö, 
betakarító és osztályozó eszközök, valamint a tárolók megfelelö fertőtlenítését mindig biztosítani kell.

* Betakarítási idő helyes megválasztása. Csak teljesen érett gumókat takarítsunk be. Ha a gumókat a lombozat elhalása után 7-10 napig a talajban hagyjuk, a parásodás végbemegy, a betakarításkor kisebb a gumósérülés veszélye. A betakarításhoz $10-18{ }^{\circ} \mathrm{C}$ os talajhőmérséklet kedvező; a $20-21{ }^{\circ} \mathrm{C}$ feletti talajhőmérséklet mellett betakarított gumók nagyon fogékonyak a tárolás során a nedves rothadásra.

* Kíméletes betakarítás, válogatás, szállítás során a fertőzés egyik forrását jelentő gumó epidermisz sérülések száma jelentősen csökkenthető.

* Tárolási viszonyok. A betakarítást követően mielőbb hütsük a gumókat $10{ }^{\circ} \mathrm{C}$-ra, vagy az alá. A tárolás alacsony hőmérsékleten történjen, lehetőleg $1,6-4,5^{\circ} \mathrm{C}$ között. A megfelelő szellőzés nemcsak az optimális tárolási hőmérséklet kialakítását szolgálja, de szabályozza a levegő összetételét is, meggátolja a $\mathrm{CO}_{2}$ feldúsulását, valamint a nedvességfilm kialakulását a gumók felületén. A szórt fényben tárolt burgonya ellenállóbb a nedves rothadásnak, mint a teljes sötétségben raktározott.

* A gumókat tiszta, klórozott vízzel mossuk meg a feldolgozás vagy csomagolás előtt és amilyen gyorsan lehetséges, szárítsuk meg mielőtt jól szellőző zsákokba, vagy konténerekbe csomagoljuk.

Fentiek betartása elengedhetetlen ahhoz, hogy az Pectobacterium és a Dickeya fajokkal való fertőzések veszélyét minimálisra csökkentsük, megfelelő minőségű vető-, vagy étkezési gumót állítsunk elő.

\subsubsection{Az almát károsító baktériumfaj}

Az almatermésű növényfajok ,tüzelhalás” betegségét az Erwinia amylovora (Burrill) Winslow et al. nevü baktérium okozza. Az első írásos feljegyzések a betegségről 1780-ból származnak, amikor azt New York államban egy körteültetvényben észlelték. Burrill 1882-ben publikálta először, hogy az elhalást okozó patogén szervezet a Micrococcus amylovorus. Elsőként Joseph C. Arthur végezte el 1884-ben az izolálást, és kísérletben bizonyította, hogy a betegség közvetlen okozója egy baktérium. Az Erwinia nemzetség, ill. Ea faj megjelölés Winslow et al. (1920) nevéhez füződik, ettől kezdődően a kórokozó neve Erwinia amylovora (Burrill) Winslow et al., amelyet 1923-tól az Amerikai Bakteriológiai Társaság hivatalosan is elismert (van der Zwet és Beer, 1995). 
A baktériumot a mai napig a világ mintegy 46 országában észlelték. A kórokozót az 1950-es évek végén kezdték el behurcolni szaporítóanyaggal Észak-Amerikából a többi kontinensre; először nyugat Európába (Anglia, 1957) és Észak-Afrikába (Egyiptom).

Európában Szlovénia volt az utolsó „Erwinia mentes” ország, míg 2001-ben itt is megjelent elszórtan egy-egy fertőzési góc, majd 2003-ban nagyobb járványról számoltak be (Dreo et al., 2006).

Magyarországon 1995 őszén egy nyárlőrinci almaültetvényben észlelték először a tüzelhalás tüneteit. Dr. Hevesi Mária azonosította az Ea karantén baktériumot (Hevesi, 1996). A hazai megjelenés után két évvel a fertőzésmentes megyék száma mindössze Vas és Nógrád megyére korlátozódott (Németh, 1999). A következő járványos évben (2000) 3263 ha alma-, 452 ha körte- és 65 ha birsültetvény volt fertőzött, ami összesen 3780 ha-t tett ki (Pálfi et al., 2000). Mára már egyik megyénk sem mentes a kórokozótól.

Az Ea Gram-negatív baktérium az Enterobacteriacae családba tartozik, peritrich flagellákkal rendelkezik. Sejtmérete 1,0-2,5 $\mu \mathrm{m}$ x 0,8-1,2 $\mu \mathrm{m}$. Fakultatív anaerob, a glükózt aerob és anaerob körülmények között egyaránt képes bontani.

A gyümölcstermesztési szempontból jelentős alma és körte mellett a Rosaceae családon belül közel 200 faj gazdanövénye az Ea kórokozónak. Gazdanövényei közül kereskedelmi szempontból a Cotoneaster, Crataegus, Cydonia, Malus, Pyrus, Photinia, Pyracantha és Sorbus nemzetséghez tartozó fajok a legfontosabbak. A tüzelhalás betegsége nemcsak az almatermésü fajokat veszélyezteti. Japán szilva (Prunus salicina) fiatal hajtásainak természetes fertőződését már 1993-1994-ben megfigyelték (Mohan és Thomson, 1996).

Németh (1998) adatai szerint a fertőzött magyarországi növényeknek 48,7 \%-a birs, 21,6 \%-a alma, 15,2 \%-a körte, 6,5 \%-a naspolya, 4,3\%-a galagonya és 3,5 \%-a egyéb növény. A birsek szokatlanul magas fertőződési aránya nem csupán a faj extrém fogékonyságának tulajdonítható, hanem a kései virágzásnak, amikor a hőmérsékleti viszonyok már optimálisak a kórokozó felszaporodásához. Így a virágfertőzéshez a virágzás teljes időszakában rendelkezésre áll a megfelelő inokulum.

A fertőzéseket elsődleges és másodlagos fertőzési ciklusokra lehet bontani (van der Zwet és Keil, 1979).

A betegség kifejlődése tavasszal, kedvező körülmények esetén veszi kezdetét, amikor a fertőzött fás szövetekben vagy a fekélyes sebek szélén, az egészséges szövetek határán áttelelő baktériumok szaporodni kezdenek. Mikor megindul a nedvkeringés, a felszaporodott baktériumok tömege baktériumnyálka formájában a felszínre tör. A sebekből szivárgó nedvben a baktériumsejtek milliárdjai vannak jelen, melyek rovarokkal, madarakkal, metszéssel, 
csapadékkal és a széllel terjednek. A virágok szöveteibe a kórokozó a természetes nyílásokon (a nektárium kiválasztó nyílásai, bibe, portok természetes nyílása, csészelevelek légrései) keresztül jut be. A virágfelületen a fertőzés hatására megjelennek a baktériumnyálka cseppek, amelyekböl az esőcseppek és a viráglátogató beporzó rovarok terjesztik tovább a baktériumsejteket. A baktérium a fertőzött pollennel is terjed. A kórokozó a sejtközötti járatokban szaporodik. A virágzatból a virágkocsányon át a vesszőkbe majd az ágakba hatol. Itt az időjárástól és a szövetek fogékonyságától függően halad előre, majd végül kialakulnak a fekélyes sebek.

$\mathrm{Az}$ elsődleges fertőzés során keletkező inokulumtömeg a fenológiai fázistól, valamint az időjárási körülményektől függően a másodlagos fertőzés útján további fertőzéseket idéz elő. A másodlagos fertőzések a vegetációs időben bármikor bekövetkezhetnek. Fertőzési forrás lehet a hajtásokon, leveleken, gyümölcsökön és nagyobb ágakon keletkező baktériumnyálka, illetve a megszilárdult nyálkaanyag által összeragasztott baktériumsejtekböl létrejött úgynevezett fonalas struktúra is.

A baktériumfonalak a szél segítségével nagyobb távolságokra is eljuthatnak. Másodlagos fertőzésre különösen érzékenyek a másodvirágzatok és a növekedésben levő hajtások. A zsenge hajtások fertőződése a sebzéseken és a természetes nyílásokon egyaránt végbemehet. Minél idősebb növényi szövet felé halad a fertőzés, annál lassabb a szaporodása. A már befásodott hajtásban a baktérium szaporodása megáll. Az éves folyamat végén a fertőzött szövetek elhalnak, és kialakulnak a rákos sebek. Ekkor a baktériumsejtek nagy része elpusztul, az életben maradt sejtek azonban áttelelnek, és tavasszal újabb fertőzési forrásként szolgálnak.

A kórokozó terjedése esö- és öntözővíz, rovarok, virágpor, szél, vándormadarak útján, az emberi tevékenységgel kapcsolatosan pedig szaporítóanyag, árugyümölcs és mủvelőeszközök útján terjed (Németh, 1997).

Baktérium nyálkacseppek a növény bármely részén megjelenhetnek. A friss nyálkacseppek tejfehérek és hígan folyósak, ezzel szemben a régi cseppek sürün folyósak vagy akár szilárdak, színük a sárgás krémszínütől a sötétbarnáig terjed. Megfigyelések szerint a friss exudátum a meleg, párás napok után jelenik meg és gyakran csak a reggeli órákban, harmat vagy magas légnedvesség esetén látható (Richter, 1999). A beszáradt nyálka fonálszerü, a rajta lévő baktériumsejtek következtében fertőzőképes. A beszáradt fonalakat a szél terjeszti. Az eső mind a primer, mind a szekunder fertőzés kialakulásában felelős lehet. Az esőcseppek egyrészt lemossák a növény felületén lévő epifiton formában lévő vagy baktériumnyálkában lévő kórokozót a fa alacsonyabb részeire, másrészt viharos időben a szél további gazdanövényekre szállítja a vízcseppekben lévő inokulumot. Az esőztető öntözés kórokozót terjesztő hatása is ezen az elven alapul. Az eső indirekt hatása a betegség kialakulásában úgy nyilvánul meg, hogy a 
baktérium szaporodását gátló tömény nektárt felhígítja, így optimális közeg alakul ki a baktérium szaporodásához (van der Zwet, 1979, Hevesi et al., 2004).

A fertőzésre kedvezö körülmények a virágzás kezdetén, valamint az intenzív hajtásnövekedés időszakában akkor vannak, amikor a napi középhőmérséklet magasabb, mint $18{ }^{\circ} \mathrm{C}$, a napi csapadék több mint 2,5 mm, a relatív páratartalom pedig $70 \%$ felett van. Mivel a virágzáskori fagyok mikrosérüléseket okoznak a virágzaton, ezért azok is elősegíthetik a fertőződést (Németh, 1997).

Kora tavasszal a fekélyes sebekből származó nagy cukortartalmú baktériumnyálkát látogató rovarok széthurcolják az inokulumot, de a virágra csak ritkán kerül ilyen módon a kórokozó. A méhek a másodlagos terjesztésben vesznek részt, amikor is a fertőzött virágról az újonnan kinyílt virágokra szállítják a kórokozót (Thomson, 2000). A vándormadarak az elfogyasztott fertőzött gyümölccsel, illetve ürülékükkel és a testükre tapadt baktériumnyálkával terjesztik a betegséget.

A tüzelhalás jellegzetes tüneteit könnyű felismerni és megkülönböztetni, mivel nem hasonlítanak más növényi betegségtünetekhez. A baktérium fejlödése követi a gazdanövény évszakhoz kötött életritmusát, ezért tüneteinek megjelenése is ciklikus. A betegség jellegzetes tüneteit van der Zwet és Keil (1979) írta le. Mivel a kórokozó valamennyi növényi részt képes megtámadni, ezért a tüneteket is ennek megfelelően csoportosíthatjuk.

A vegetáció során először a virágelhalást előidéző tünetek jelennek meg 1-2 héttel a sziromhullást követően. A fertőzött virágszövet először vízzel átitatott lesz, majd szürkészöld megjelenésű, később hervadni kezd, majd elszárad és barnás-feketén elhal. A csészeleveleken, virágkocsányokon is megfigyelhetők a vízzel átitatott foltok, meleg, párás időben rajtuk a betegségre jellemző baktériumnyálka (exudátum) jelenik meg. Ezek a nyálkacseppek kezdetben krémes fehér színűek, majd idővel egyre borostyánabb színezetet öltenek (Johnson, 2000). Exudátum képződés hiányában a virágzat megbetegedése csak a virágzás után állapítható meg egyértelműen, mert a fertőzött, megbarnult, megfeketedett virágok és terméskezdemények a fán maradnak. A virágzaton kiváló exudátumcseppek egyben a hajtás fertőzésének is forrásai.

A hajtás- és levélelhalás a betegség leginkább jellemző tünete, mely a virágfertőződéshez hasonló azzal a különbséggel, hogy a fertőzés sokkal gyorsabb, akár 15-30 cm/nap sebességgel is terjedhet a hajtásban látható tünetek kialakulása nélkül és különösen kedvező időjárás esetén (meleg, párás) a napi 50-70 cm-t is elérheti. A hajtások a csúcs vagy az alap felől szisztemikusan fertőződnek. A virágzás utáni intenzív hajtásnövekedési periódusban a fertőzött, még nem fásodott hajtásvég pásztorbotszerüen visszagörbül, a levelek megbarnulnak, de nem hullanak le (6. ábra). Optimális időjárási körülmények között a hajtáson baktériumnyálka cseppek jelennek meg. A vegetáció későbbi szakaszában, amikor a növények növekedése erősen lelassul, a fertőzés csak a hajtások végére korlátozódik, és a már megfásodott hajtásvégek pásztorbotszerü 
meghajlása nem következik be. A hajtás- és levélelhalásnak köszönhetően a fa olyan benyomást kelt, mintha megégett volna, innen ered a tüzelhalás elnevezés.

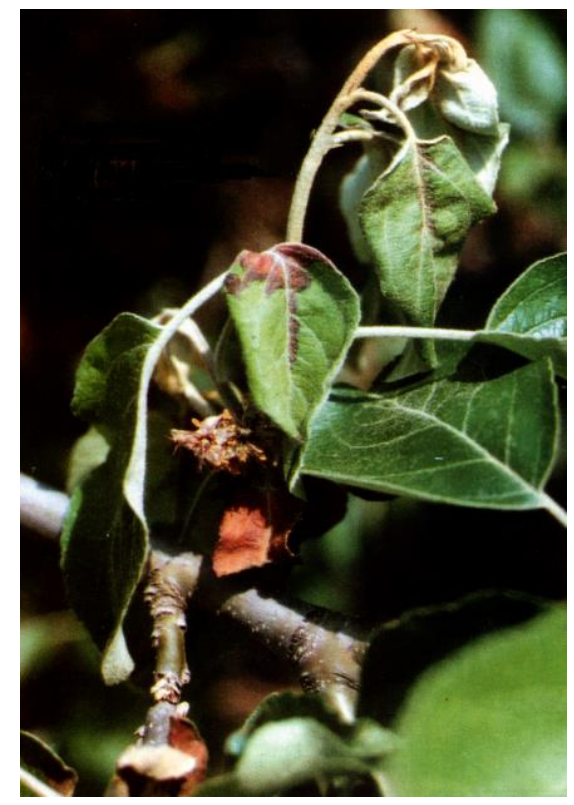

6. ábra. Fertőzött alma hajtáscsúcson kezdődő elszineződés és a levélnyél felől terjedő levéllemez elhalás (Fotó: Bubán Tamás)

A fiatal és a kifejlett gyümölcsökön hasonló a betegség megjelenése. A fertőzött gyümölcsök vizenyősek lesznek, rajtuk nyálkacseppek jelennek meg, majd megbarnulnak és végül teljesen megfeketednek. A mumifikálódott termések a fán maradnak, vagy lehullanak. Az érett gyümölcsök a bőrszövet paraszemölcsein, sérülésein, valamint a fertőzött vesszőből, gallyból a kocsányon keresztül egyaránt fertőződhetnek.

A fa törzsén és ágain a vegetáció második felére a fertőzések hatására besüppedt kéregelhalások, fekélyes sebek alakulnak ki, melyek a kórokozó áttelelését szolgáltatják. Az ágakban és a törzsekben gyorsan elörehaladó fertőzés hatására a felületen bőséges exudátum válhat ki, amely végigfolyik az ág és a törzs felületén. Az egészséges és beteg felületek határán a kéreg rendszerint felreped. Az ágak kérgének eltávolítása után a fás részen gyakran jellegzetes vörösesbarna csíkozottság is megfigyelhető.

A tủzelhalásnak ez a két típusa a legveszélyesebb és gyakran okozza az egész fa pusztulását. A fertőzés a gyökérnyakból jut a gyökerekhez, de az is előfordul, hogy ez az irány fordított. A fertőzés a fiatal sarjhajtásokból, az egyéb föld feletti fa részekből az edénynyalábrendszeren keresztül szisztemikusan lejutó vagy a fakoronából az ág és a törzs felületéről lemosódó baktériumok okozzák. 
Az Ea elleni védekezés nagyon nehéz és drága, ezért igen fontos a vele szemben toleráns fajták termesztésbe vonása olyan termőhelyeken, ahol a kórokozó veszélyes lehet. A védekezés első és legfontosabb lépése - a megelőzésen túl - a betegség korai felismerése. Ezen felül az eredményes védekezés záloga a különböző módszerek (agrotechnikai elemek, növényegészségügyi rendszabályok, rezisztens és toleráns fajták termesztése, kémiai és biológiai védekezés) együttes, integrált módon való alkalmazása.

A védekezési lehetőségeket a következőképpen lehetne összefoglalni:

Az előrejelzési módszereket illetően a növényvédőszeres kezelések hatékonysága szempontjából kulcsfontosságú szerepe van az időzítésnek. Megfelelő hatásuk csak az időben elvégzett kezeléseknek van. A jelenleg ismert előrejelzési módszerek közül Európában a Billingféle (Firescreens) modell terjedt el, mely a kórokozó napi szaporodási ütemére épülő becslésen és a csapadék mérésén alapul. A másik módszer a Marybylt rendszer, ami viszont az időjárási adatokat veszi figyelembe (Sobiczewski et al., 1997). Ezt a rendszert alkalmazzák hazánkban is.

Szaporítóanyag előállítás, forgalmazás esetén alapvető követelmény a fertőzésmentesség. A növényegészségügyi rendszabályok a betegség bármilyen formában történő behurcolását igyekeznek megakadályozni. A betegség bejelentés köteles, azaz fellépése vagy annak gyanúja esetén értesíteni kell a területileg illetékes mezőgazdasági szakigazgatási hivatalt. A hatóság zárlati intézkedéseit maradéktalanul be kell tartani (Németh, 1997).

A védekezés agrotechnikai módszerei közül a következőket emelném ki Németh (1997) alapján:

* Kerüljük a mély fekvésü, tápanyagban szegény, rosszul szellőző, nehéz és savanyú talajjal rendelkező területeket.

* Figyelembe kell venni a fajok és fajták közötti fogékonyságbeli különbségeket.

* Kerüljük a túlzott nitrogéntrágyázást, mert az elősegíti az intenzív hajtásnövekedést, ezáltal meghosszabbítva azt az időszakot, amikor a növények egyébként is fogékonyak a fertőzésre.

* Metszést kizárólag nyugalmi időben végezzünk, kerüljük a túlzott visszavágást, ami ugyancsak kedvez az intenzív növekedésnek.

* Metszés során az áttelelő fekélyes sebekkel rendelkező gallyakat, ágakat távolítsuk el.

* Fertőzött állományban kerüljük a nyári zöldmetszést, de ha ez elkerülhetetlen, a metszőolló rendszeres fertőtlenítése szükséges.

* Fertőzött hajtást 40-60 cm hosszú egészséges résszel együtt kell eltávolítani.

* Az eltávolított részeket elégetéssel minél előbb semmisítsük meg. 
Vegyszeres kezeléseknél elsősorban rézkészítmények és elméletileg antibiotikumok jöhetnek szóba. A rézkészítmények közül leggyakrabban a réz-hidroxid, a réz-szulfát és a rézklorid hatóanyagú szereket használják (Sobiczewski et al., 1997). A rézvegyületek alkalmazása során figyelembe kell venni, hogy virágzási időszakban fitotoxikus hatást fejthetnek ki. Érdemes a készítményekkel tél végi, lemosó permetezéssel védekezni.

A tűzelhalással szemben a leghatékonyabb módszer az antibiotikumok használata volt. A szerzett antibiotikum rezisztencia azonban a kórokozó baktérium populációjában eleinte lokálisan, később kiterjedtebb gondot okoz. Ez a tény korábban nagyhatású antibiotikum gyakorlatból történő kiszorulásához vezetett. Sajnos egyértelmüen bebizonyosodott, hogy az antibiotikumok agronómiai célú felhasználása során a rezisztencia gyorsan kialakulhat (Sholberg et al., 2001). Az antibiotikumok közül a sztreptomicin az Amerikai Egyesült Államokban virágzáskor és intenzív hajtásnövekedéskor használatos. Tapasztalatok szerint 6 év használat után alakult ki az antibiotikum rezisztencia, viszont sztreptomicin rezisztens $E a$ törzseket már Új-Zélandon is találtak (Sobiczewski et al., 1997). A sztreptomicint az Európai Unió több országában betiltották, így hazánkban is elsősorban humánegészségügyi okok miatt.

A kasugamycin hatóanyagú Kasumin 2L Magyarországon 1997 óta engedélyezett növényvédő szer volt. Sobiczewski (1997) szerint a készítmény alma és körteültetvényekben fitotoxikusnak mutatkozott, használata ezért csak faiskolában és egyes dísznövényeknél ajánlott. A Kasumin 2L virágzáskor és a későbbiekben is fitotoxikus lehet: sziromperzselést, levélperzselést okozhat (Halmágyi, 1997). A Kasumin 2L hazánkban csak eseti engedélyezés mellett használható.

Egyéb készítmények közül hazánkban a fozetil-Al hatóanyagú Aliette 80 WG - a Kasuminhez hasonlóan - szabad forgalmi kategóriájú szer. Larue és Gaulliard (1993) szerint az Aliette a rézkészítményeknél jobb, a sztreptomicinnel esetenként azonos hatékonyságú. Más szerzők a fenti megállapítást cáfolják (Hevesi, személyes közlés).

Szisztemikusan szerzett rezisztenciát indukáló szerek közül a Prohexadione-Calcium (Regalis) növekedésgátló anyagot, valamint a Bion 50WG nevü növényaktivátort említeném meg, melyek több esetben is hatékonynak bizonyultak az $E a$ elleni küzdelemben. A Prohexadine-Ca az Ea szaporodását in vitro nem befolyásolta ugyan, de miután a betegség kifejlődésére gátló hatású, ezért feltételezik (Roemmelt et al., 1998), hogy szintén szisztemikusan szerzett ellenállóképességet indukál. Hazai kísérletekben Bubán és munkatársai (2006) in vitro virágfertőzésekben szintén hatásosnak találták ezeket az indukált rezisztenciát fokozó szereket.

A biológiai védekezés kidolgozására az $E a$ esetében közel két évtizede zajlanak kutatások antagonista, epifiton baktériumok alkalmazásával. Ezek hatása gátló anyagok termelésén és a 
tápanyagokért folyó versenyen alapul, ezért kijuttatásuknak már a kórokozó megjelenése előtt meg kell történnie. Az antagonista baktériumoknak a sebfelületen és a virágok nektáriumainál kell lennie, mielőtt a kórokozó odajutna.

A Pseudomonas fluorescens az egyik leggyakrabban vizsgált epifiton baktériumfaj, melynek egyes törzsei hatásosnak bizonyultak a baktérium elleni védekezésben. Az A506-os törzse kísérletekben csökkentette a fagykárt és a tüzelhalás tüneteit az USA -ban szabadföldi kísérletben (Lindow et al., 1996) és Új-Zélandon is (Vanneste, 2006). A P. fluorescens A506 törzséből kereskedelmi forgalomba hozott terméket is előállítottak: Blightban A506 ${ }^{\circledR}$, melyet az éppen kinyílt virágoknál érdemes kipermetezni (Elkins et al., 2005).

A Pantoea agglomerans (syn. E. herbicola) egy antibiotikumot termelő baktérium, amely specifikusan hat az Ea-ra és a kórokozót elpusztítja (Vanneste, 1996; Johnson és Stockwell, 1998; Al-Arabi, 2002; Özaktan és Bora, 2006). A Pantoea agglomerans hatásosnak bizonyult törzseiből (P10c) kereskedelmi forgalomban lévő készítmény is készült BlossomBless ${ }^{\mathrm{TM}}$ (ÚjZéland) és PomaVita ${ }^{\mathrm{TM}}$ (Olaszország) (Vanneste, 2006). A Hevesi Mária által izolált $P$. agglomerans HIP 32-es törzse in vitro kísérletben szintén erősen gátolta az Ea szaporodását (Hevesi et al., 2006).

Bacillus subtilis törzsek vizsgálata során derült fény arra, hogy hatásosak több kórokozó-, így az Ea elleni védekezésben is. Ugyancsak leírták Photorhabdus és Xenorhabdus fajok erős antibakteriális hatását (Böszörményi et al., 2009). Fontos azt tudnunk, hogy az antagonista baktériumok használatával a kórokozót nem pusztítjuk el, csupán annak felszaporodását gátoljuk (Németh, 1997).

A bakteriofágok használata sem elhanyagolható a tüzelhalás elleni védekezésben. Svircev et al. (2005) végeztek vizsgálatokat az Ea bakteriofágjaival. Szabadföldi kísérletben jutattak ki fágokat körtevirágokra. Hordozóként Pantoea agglomerans használtak, melynek az antagonista szerepe is fontos szempont volt. Ez a kombináció egyértelműen hatékonynak bizonyult. Hazai kutatók is vizsgálták a bakteriofágokban rejlő lehetőségeket. Schwarzinger et al. (2011) fertőzött körte-, alma- és birsszövetekből izoláltak fágokat, melyekkel almavirágokat kezeltek $E a$ fertőzés előtt. Ugyanakkor táptalajon is tesztelték a fágok hatékonyságát. Tapasztalataik szerint a bakteriofágok mind a virágokon, mind pedig a táptalajon visszaszorították a kórokozó baktérium szaporodását. Kolozsvári Nagy et al. (2012) hazai Ea törzsekből izoláltak bakteriofágokat, amelyek nem csak hazai törzseket voltak képesek fertőzni. Hazai vonatkozásban meg kell említeni az Erwiphage elnevezésü bakteriofágokat tartalmazó növényvédőszert, mely 2014-ben március 15-től rendelkezik 75 napos, ideiglenes felhasználási engedéllyel az almatermésű kultúrákban. 
Az ellenálló fajták termesztése jelentheti a legjobb megoldást. A tüzelhalás kórokozójával szembeni ellenállóságra való nemesítésre nagy erőfeszítések történtek, ennek ellenére a gyakorlatban termesztett toleráns fajták száma korlátozott. A fajták szinte mindegyikét képes a baktérium megfertőzni, egy részük azonban különböző mértékben türi azt, vagyis a tünetekben és terméskiesésben megnyilvánuló jelentős negatív hatás nem érvényesül.

Az egyes gyümölcsfajok és fajták fogékonyságáról az irodalomban eltérő közléseket is találunk. Ennek egyik oka lehet a különböző klimatikus körülmények, a fertőzési és értékelési módszerek sokfélesége, a baktériumtörzsek eltérő virulenciája (Hevesi et al., 2000) és az a tény, hogy az egyes növényi szervek fogékonysága gyakran különböző (Fischer és Schaefer 1990, Fischer és Fischer 1994, Berger és Zeller, 1994).

Mowry (1964) Illinois államban 203 almafajta fogékonyságát vizsgálta. Ötéves fáknál a legkevésbé volt fogékony pl. a 'Starkimson Delicious', mérsékelten fogékony volt pl. a 'Golden Delicious', fogékonynak pl. a 'Mutsu', a 'Jonathan' és 'Idared' mutatkozott.

Le Lezec et al., (1984, 1987) vizsgálatai során a varasodásrezisztens almafajták 'Prima', 'Florina', 'Liberty' tüzelhalás-rezisztensnek bizonyultak. Rezisztens tüneteket mutatott még a 'Smoothee', a 'Golden Delicious', és a 'Mutsu', mérsékelten rezisztens volt a 'Gala' és a 'Granny Smith'.

Németországban 1974-ben kezdődtek a rezisztencianemesítések. A rezisztens szülők utáni kutatások során a külföldi rezisztens fajták eltérő eredményeket mutattak. Magas rezisztenciájú volt az 'Enterprise' (USA) és a 'Selena' (CZ), mérsékelten rezisztens a 'Florina' (F) és a 'Nabella' (CZ). Mérsékelten vagy erősen fogékonynak bizonyult az 'Otava', 'Rayka', 'Zuzana', 'Delorina', 'Vanda', 'Freedom', 'Lotos', 'Ecolette', 'Produkta', 'Topaz', 'Rosana', 'Dayton', 'Prima', 'Priscilla' (Fischer és Richter, 1999). A legveszélyeztetettebb fajták, pl. a 'Gloster', az 'Elstar', a 'Gala', a 'Rubinette', a 'Jonagold' és az 'Idared'.

A németországi nemesítések során szülőfajtaként magas rezisztenciafokú almafajtákat és nemesítési törzseket használtak fel diallélos keresztezésben, topcross-ban és visszakeresztezésben. A legtöbb tűzelhalás-rezisztens szülőfajta a Malus floribunda keresztezéséből származik. A tüzelhalással szembeni rezisztencia az utódokban növelhető azáltal, hogy mindkét, a keresztezésben részvevő szülőfajta rezisztens. A tüzelhalás-rezisztencia megoszlása az utódnemzedékekben megmutatta, hogy a tüzelhalás-rezisztencia genetikailag poligénes. A tüzelhalás estében nem lép fel juvenilis fogékonyság, mint az az almalisztharmatnál ismert. A rezisztens x rezisztens keresztezés utódnemzedéke magas rezisztens arányt eredményezhet. A „Re” fajták különösen erős fertőzési körülmények között is jó rezisztencia-stabilitással rendelkeznek (Fischer és Schaefer, 1990; Fischer és Fischer, 1994). A „Re” fajták között ígéretesek a tüzelhalással szemben rezisztens 'Reanda', 'Rewena', ill. 
mérsékelten rezisztens 'Realka', 'Rebella', 'Regia', 'Regine', 'Reglindis', 'Releika', 'Remo', amelyek varasodással és lisztharmattal szemben is rezisztensek (Fischer és Fischer, 1994; Fischer, 2004). A rezisztenciát mutató vad fajok nemesítésben való felhasználásával a kedvező tulajdonságok mellett a kedvezőtlen tulajdonságok is megjelennek az utódokban (rossz gyümölcsminőség) (Baumgartner et al., 2012).

A Budapesti Corvinus Egyetem Gyümölcstermő Növények Tanszékén a multirezisztenciára irányuló almanemesítési kutatások egy része volt a Kárpátaljáról származó, történelmi almafajták tüzelhalással szembeni ellenállóképességének vizsgálata. A fogékonyság vizsgálatok során a fajták többsége mérsékelten vagy nagyon fogékonynak bizonyult. Mérsékelten rezisztens volt a 'Szemes alma', 'Pónyik alma', 'Sikulai', 'Batul', 'Zöld sóvári' és a 'Vilmos renet'(Kása et al., 2003, Tóth et al., 2005). A virág- és hajtásfertőzés eredményei alapján kiemelhetők a 'Szabadkai szercsika' és a 'Tordai piros kálvil' fajták, melyek a rezisztencianemesítési programokban génforrásnak javasolhatók (Tóth et al., 2013a). A kiváló hajtásellenállósággal, de mérsékelt virágfogékonysággal rendelkező 'Sikulai' és a 'Pónyik' a gombás betegségekkel szemben sem volt fogékony, ill. a gyümölcs minősége is jó volt, ezért ezek nem csak nemesítési génforrásként, hanem ökológiai termesztésben is felhasználhatók (Tóth et al., 2005, 2013a). A BCE Gyümölcstermő Növények Tanszéken a 'Prima’ szülőfajtaként való felhasználásával is sikerült a toleranciát, illetve rezisztenciát az utódokba átvinni, $\mathrm{s}$ az egyéb betegségekkel szembeni ellenállóképesség, valamint a gyümölcsminőség értékelése alapján perspektivikus hibridek kiemelésére került sor (Tóth, 2005). Ennek a nemesítési munkának az eredményeként 2011-ben és 2012-ben államilag elismert fajta lett az 'Artemisz', a 'Cordelia', 'Hesztia' és a 'Rosmerta' (Tóth et al., 2012).

A termesztett almafajták szortimentjében rendelkezésre álló rezisztenciadonorok mellett a vad fajokban is találtak olyan génforrásokat, amelyek a rezisztenciát hordozzák. Amerikai kutatások szerint a különböző Malus fajok, mint a Malus robusta és a Malus sublobata meglehetősen rezisztensek a tüzelhalással szemben. Ezeket a tulajdonságokat használták fel, pl. Genevában, New Yorkban új almaalanyok nemesítéséhez (Oberhofer, 1993).

A több éves tapasztalat alapján látható, hogy a védekezés csak integrált módszerek együttes alkalmazása mellett valósítható meg, de a fertőzés teljesen nem szüntethető meg, csak a kártétel mértéke csökkenthető. Az integrált eljárások egyik fontos tényezője a fajták rezisztenciájának ismerete. A tüzelhalással szembeni harcban is az egyik legfontosabb tényező a gazdanövény fogékonysági szintjének ismerete. 


\subsection{Kiemelések a növényi stresszfolyamat ismeretköréből és a növények antioxidáns védelmi rendszeréből}

A növények, az összes többi élőlényhez hasonlóan, számtalan környezeti hatásnak vannak kitéve életük során. Ezek lehetnek abiotikusak (szárazság, hőmérsékletváltozás, erős fény, tápanyaghiány stb.) és biotikusak (kórokozókkal történő fertőződés) is. E hatások gyakran az optimális életkörülményektől kisebb-nagyobb mértékben eltérőek lehetnek (környezeti stressz), ezzel alkalmazkodásra késztetve a helyhez kötött életmódot folytató növényeket.

A stressz kifejezés elsőként Selye János endokrinológus használta. Meghatározása szerint a stressz az élőlény válaszát, míg a stresszor a környezeti hatást jelöli. A stresszor hatására jelentkező tünetegyüttes pedig az adaptációs szindróma (Selye, 1975).

Larcher (1987) a növényekre vonatkozóan következőképpen fogalmazta meg a stressz definícióját, mely tulajdonképpen a Selye által megfogalamzott általános adaptációs szindróma leírása: „A stressz egy olyan terheléses állapot, amelyben a növénnyel szembeni fokozott igénybevétel a funkciók kezdeti destabilizációját követően egy normalizálódáson át az ellenállóság fokozódásához vezet, majd a türéshatár túllépésekor tartós károsodást vagy akár pusztulást is okoz." Ez tulajdonképpen a Selye által megfogalmazott általános adaptációs szindróma leírása. A potenciálisan káros tényezőket, melyekre a növény valamely élettani folyamatának a megváltoztatásával válaszol, stresszfaktoroknak vagy stresszoroknak nevezzük, az általuk létrehozott körülmények pedig a stresszhatások.

Szigeti (1998) szerint a stressztényezőket többféle szempont szerint csoportosíthatjuk: kiegészítve az abiotikus és biotikus stresszt antropogén vagy természetes környezeti eredetü stresszhatásokkal. A stressz erősségének mértéke alapján megkülönböztetünk distresszt, mely türéshatárt meghaladó mértékü stressz, és a szervezet károsodásával, illetve pusztulásával jár, másrészt van az eustressz, mely gyengébb hatású, elviselhető mértékü stressz, ami védekezésre ösztönzi az adott élőlényt.

A növényeket érő stresszhatások következtében anyagcsere változások jönnek létre. Szinte valamennyi típusú stressz esetében az egyik legjellegzetesebb válasz a reaktív oxigénformák (ROS $=$ reactive oxygen species) képződése és a sejten belüli oxidatív mikrokörnyezet kialakulása (Baker és Orlandi, 1995; Bestwick et al., 1997; Stefanovits-Bányai, 2008).

Míg a molekuláris oxigén nem reakcióképes vegyület (Cadenas, 1989), addig az oxigén reaktív formái annál inkább. A legfontosabb ROS-ok a következők: a szinglet oxigén $\left({ }^{1} \mathbf{O}_{2}\right)$ nem rendelkezik párosítatlan elektronnal, de reakcióképessége miatt mindenképpen ide sorolandó. Egy elektron felvételével szuperoxid gyök $\left(\mathbf{O}_{2}{ }^{--}\right)$keletkezik a molekuláris oxigénből. A reakció 
lejátszódásához enegiára van szükség, melyet az élő rendszerekben a nikotinamid-adenindinukleotid-foszfát (NADPH) szolgáltat. Egy proton felvételével a szuperoxid anion hidroperoxil gyökké $\left(\mathrm{HO}_{2}{ }^{\circ}\right)$ alakul át, vizes oldatban pedig hidrogén-peroxidot $\left(\mathrm{H}_{2} \mathrm{O}_{2}\right)$ képez. A hidrogén-peroxid viszonylag stabil, elektromosan semleges, így képes áthatolni a membránokon. A legreakcióképesebb oxigénforma a hidroxil gyök (HO), mely erősen oxidatív tulajdonságú vegyület. Jelentős mennyiségben az átmeneti fémek - vas $\left(\mathrm{Fe}^{2+}\right)$ és réz $\left(\mathrm{Cu}^{+}\right)$ oxidációja során keletkeznek. Annak ellenére, hogy ezek toxikus gyökök/molekulák és károsan hatnak a nukleinsavakra, fehérjékre és lipidekre, a növényekben számos élettani folyamat szabályozásában részt vesznek (Mittler, 2002).

Az oxidatív stressz egy olyan sejtállapot, amelyben a ROS koncentrációja megemelkedik. Egy egészséges növényi sejtben ROS-k kismértékben folyamatosan keletkeznek. Az oxidatív stressz akkor alakul ki, amikor a sejt antioxidáns védelmi rendszere és az oxidatív körülményeket kiváltó mechanizmusok egyensúlya felborul (Smirnoff, 1998; Apel és Hirt, 2004; Diaz-Vivancos et al., 2006).

A különböző káros oxigénformák sejtkárosító hatásának kivédése az antioxidáns rendszerek feladata a növényekben (Vanacker et al., 1998). Az enzimatikus és nem-enzimatikus antioxidánsok mennyisége és aktivitása jelentős mértékben változik a növény fejlődése során, összefügg annak élettani állapotával (Barna, 1995; Barna et al., 2003).

Alapvető különbség van azonban a különböző típusú stresszorok között: a biotikus stressz megnyilvánulása kezdetben lokális, csak a fertőzés helyén lévő sejtek anyagcseréjét érinti, majd fokozatosan terjed ki az egész növényre. Az abiotikus stressz ezzel szemben egyszerre fejti ki hatását a teljes növényi szervezetre. A káros oxigénformák termelődése számos gazda-parazita kapcsolat, valamint abiotikus stressz által előidézett folyamat során fokozódik. A kórokozók fertőzése olyan növényi enzimek (sejtmembránban NAD(P)H-oxidáz, sejtfalhoz kötött peroxidázok) müködését indukálja, amelyek szuperoxidot és hidrogén-peroxidot termelnek. Nagy mennyiségü ROS termelődést mutattak ki pl. a paradicsom esetében fuzárium fertőzés esetén (Mandal et al., 2008), a szezámnál alternária fertőzésnél (Lubaina és Murugan, 2012). A ROS formáknak közvetlen antimikrobiális hatása van, mely csökkenti a patogének életképességét (Fang, 2011).

$\mathrm{Az}$ antioxidáns rendszer felosztható enzimatikus és nem enzimatikus részre. A legfontosabb enzimatikus antioxidánsok a szuperoxid-dizmutáz (SOD), a peroxidáz (POD), a kataláz (CAT), aszkorbát peroxidázok (APX), és a glutation-reduktáz (GR), stb. A védelmi rendszer nem enzimatikus részét vízoldékony és lipidoldékony antioxidáns vegyületek alkotják, úgymint glutation, aszkorbinsav, $\beta$-karotin, $\alpha$-tokoferol, polifenolos vegyületek, E-vitamin stb. (Pandhair és Sekhon, 2006). 
A káros oxigénformák elleni védelem első vonalát a szuperoxid-dizmutázok (SOD) jelentik, melyek a citoszólban, peroxiszómákban és kloroplasztiszokban lokalizálódnak. Az enzim a szuperoxid dizmutációját katalizálja, mely során hidrogén-peroxid jön létre, ami egy viszonylag stabil reaktív oxigénforma. Emiatt a többi ROS rövid időn belül hidrogén-peroxiddá alakul (Allan és Fluhr, 1997). Elektromosan semleges és kevésbé reaktív, ezért képes áthatolni a membránokon, így keletkezési helyéről más sejtekbe vándorolhat.

A növényi peroxidázok (POD) protohem prosztetikus csoportot tartalmazó, glükoprotein enzimek. In vivo többek között különböző fenolokat, fenolszármazékokat oxidálnak, in vitro aktivitásmérésekhez pedig számos vegyület alkalmazható, például az ortodianizidin vagy a gvajakol. A legszélesebb körben alkalmazott vegyület miatt gvajakol-peroxidáznak is nevezik az ebbe a csoportba tartozó enzimeket. Számos élettani funkciójuk ismert (Asada, 1992), többek között részt vesznek a lignin bioszintézisében (Gross, 1978), az etilén képződésében, az indolecetsav bomlásában (Salin, 1987). Jelentős szerepük van az öregedési folyamatokban (Wyen et al., 1971). Megtalálhatók a vakuólumban, a sejtfalban, a citoszólban és az apoplasztban; a sejtszervecskékben viszont - így többek között a kloroplasztiszban - nem. Élettani szerepüket az abiotikus és biotikus stresszhatások elleni védelemben több kutató is leírta (Stefanovits-Bányai et al., 1998; Szecskó et al., 2002.; Sárdi és Stefanovits-Bányai, 2006; Honty et al., 2005).

Rudolph és Stahmann (1964) már 50 évvel ezelőtt megállapította, a Pseudomonas phaseolicola baktériummal végzett kutatásai során, hogy a peroxidáz aktivitás nagyobb növekedést mutat a rezisztens babfajtákban, mint a fogékony fajtában virulens törzzsel való fertőzés esetén. Vizsgálataik során arra a következtetésre jutottak, hogy a fokozott peroxidáz aktivitás kedvez a kórokozóval szembeni rezisztencia kialakításához.

A későbbiekben számos kutatás támasztotta alá ugyanezt az eredményt, miszerint a biotikus stressz hatására a fertőzést követően az antioxidáns enzimek aktivitása - köztük a peroxidázé is általában megemelkedik (Jang et al., 2004; Djelabi et al., 2007).

Az oxidatív stressz elleni védekező mechanizmus része az aszkorbát-glutation ciklus. Mivel a kloroplasztiszokban nincsen katalázaktivitás, ezért az ott keletkező hidrogén-peroxid az aszkorbát-glutation ciklus során semlegesítődik. Ebben a ciklusban jelentős szerepet tölt be a glutation-reduktáz (GR) enzim, mely az oxidált glutationt redukálja vissza. Stressz hatására megemelkedő aktivitását már leírták (Noctor és Foyer, 1998).

Az aszkorbát-peroxidázok (APX) vastartalmú fehérjék. Többek között a hidrogén-peroxid vízzé alakulásában van szerepe. Megtalálható a citoszólban és a kloroplasztiszban, ahol a fó hidrogén-peroxid lebontó enzim (Asada, 1992).

A kataláz (CAT) négy alegységből álló, hem prosztetikus csoportot tartalmazó enzim, mely a hidrogén-peroxid bontását katalizálja. A kataláz az egyik legjelentősebb hidrogén-peroxidot 
semlegesítő enzim a növényekben, amely a peroxiszómákban, a glioxiszómákban és - kukorica esetében - a mitokondriumokban található (Salin, 1987; Scandalios, 1990).

A rezisztencia kialakulásában még számos más vegyületnek és anyagcsereterméknek (pl. szalicilsav, benzoesav, stb.) is fontos szerepe van, de dolgozatomban már csak egy vegyületcsoportra szeretnék kitérni, a szénhidrátokra.

A stresszhatásokra adott növényi válaszok közül a szénhidrátfrakciók minőségi és mennyiségi változásai fontosak, mivel a szénhidrát-anyagcsere szoros kapcsolatban áll többek között a fotoszintézissel, a transzspirációval és a légzéssel.

A monoszacharidok (glükóz, fruktóz) és a diszacharidok (szacharóz), valamint az itt említésre nem kerülő cukrok központi szerepet játszanak a növények szerkezetében és metabolikus folyamataiban. Roitsch (1999) szerint a növények az őket érő stresszhatásokra az oldható szénhidrátok felhalmozódásával válaszolnak, ami egy általános reakciónak tekinthető.

Murariu et al. (2008) különböző fogékonyságú körte-, alma- és birsfajtákban az Ea fertőzés hatására bekövetkező fiziológiai és biokémiai változásokat vizsgálták. Kimutatták, hogy a nagyon érzékeny 'Moşna' birsnél a bakteriális fertőzés hatására a komplex szerves anyagok szintézise lecsökkent, ugyanakkor ezen anyagok hidrolízise intenzívebbé vált, ezért a szénhidrátok oldható formái mintegy 121\%-os növekedést mutattak.

Milcevicová (2009) mikroszaporított 'Idared' és Mrp (nemesítési klón) növényeken végeztek mesterséges fertőzéseket, az Ea 295/93 törzzsel. A tünetek meghatározása mellett a szénhidrát tartalom változásait, ezen belül ramnóz, arabinóz, galaktóz, glükóz, szacharóz, fruktóz és maltóz, valamint cukor alkoholok (szorbitol, inozitol, pinitol, manitol) szintjeit is vizsgálták. A fertőzést követő 3. napon, a kísérlet végén, a szénhidrátok szintje általában magasabb volt az érzékeny 'Idared' fajtánál, a rezisztens Mrp klónhoz viszonyítva, azonban a különbség csak a pinitolok esetében volt szignifikáns. Az eredményekből arra következtettek, hogy az alma Erwinia elleni védekezési mechanizmusban ezeknek lehet szerepük. A rezisztens Mrp növényekben semmiféle a bakteriális fertőzéshez kapcsolható változást nem tapasztaltak.

A fertőzés hatására kialakuló válaszreakciók mind a fogékony, mind a rezisztens növényben összefüggésbe hozhatók az endogén szénhidrátok mennyiségével. A különböző gazda-parazita kapcsolatban a cukrokra jellemző változások (Sárdi et al.; 1996, 1999; Végvári et al., 2000) hasonlóak az abiotikus stresszhatásra bekövetkező változásokkal (Stefanovits-Bányai et al., 1998, 2000; Honty et al., 2008; Hudák et al., 2010). 


\section{A KUTATÁSOK CÉLJA}

Az általam vizsgálni kívánt Enterobacteriaceae családba, Erwinia nemzetségbe tartozó baktériumfajok ( $P c c, D d$ és $E a$ ) eltérő növénybetegség típusokat okoznak. Elöbbi kettő pektinbontó, ennek következtében lágyrothadás tünetet, míg a tüzelhalást okozó $E a$ hervadást, hajtásszáradást, levél- és virágkárosítást idéz elő (Waldee, 1945). Biokémiai tulajdonságaikban egymáshoz hasonlóak vagy egymástól különböznek pl. Ea szerológiai módszerrel vizsgálva homogén fajnak tekinthető, míg az E. aroideae, E. chrysanthemi baktériumfajokkal termeltetett antiszérum pozitív reakciót ad több Ea törzzsel (Lazar, 1972). A közöttük lévő jelentős különbség (kisebb mértékủ azonosság) dacára a pathogenezis folyamatában számos azonosságot találunk. Pl. mindhárom faj képes hiperszenzitív szövetnekrózist (HR) okozni nem saját gazdanövényének szövetében, így dohányban. Továbbá a hrp gének által kódolt „Harpin” fehérje, amely számos biokémiai folyamatot befolyásol, mindhárom faj esetében felelős az indukált gazdaválasz előidézésében (Hauben et al., 2005).

$\mathrm{PhD}$ kutatásaim három fő területre - rezisztenciatesztelésekre, biokémiai vizsgálatokra és vizsgálati módszerek fejlesztésére - irányultak.

A burgonya esetében a rezisztencia vizsgálatok azért indokoltak, mert munkahelyem (Debreceni Egyetem ATK Nyíregyházi Kutatóintézete) több évtizede foglalkozik burgonyanemesítéssel. Nemesítési munkánk különböző kórokozókkal, kártevőkkel szemben rezisztenciát hordozó vad Solanum fajok használatán alapul. Irodalmi adatok alapján feltételezhetjük, hogy alapanyagaink, illetve klónjaink között, a Pectobacterium és a Dickeya fajokkal szembeni rezisztenciát/toleranciát hordozók is szerepelnek. Ezek kiválasztása, rezisztenciájuk mértékének meghatározása egyik kutatási feladatomat képezi.

Az almafajták fogékonyságának/rezisztenciájának fokozatait a növények hajtásának, ill. virágának segítségével szokták meghatározni. A hajtás és virágfertőzés mértéke között bizonyos fajták esetén van, más fajták esetén nincs összefüggés. Az almafajták mikroszaporított növényeinek tesztelése a BCE Gyümölcstermő Növények Tanszék által javasolt fajták köréből a következők miatt indokolt:

- egész évben rendelkezésre állnak;

- előállításuk kevésbé költséges, mint a kifejlett növényeké;

- a mesterséges fertőzések standard körülmények között végezhetők;

- a gazdanövény válaszreakcióját kevésbé befolyásolja egyéb stresszhatás (pl. vízhiány, tápanyaghiány, kondícióromlás). 
A rezisztencia mértékének meghatározása nem képzelhető el a kórfolyamat részletes ismerete nélkül. Hazánkban mesterséges fertőzést szabadföldi körülmények között nem lehet végrehajtani, továbbá a spontán fertőződésből származó adatok sem megbízhatóak a növényállomány egyenlőtlen fertőződése miatt. A fenti okokból kifolyólag szükségesnek tartjuk inokulációs kísérletek végzését ismert virulenciájú baktériumtörzsekkel in vitro körülmények között.

Biokémiai vizsgálatokra azért van szükség, mert jogos az a feltételezés, hogy a különbözö genetikai eredetü burgonya- és almafajtákban és utódaikban a fertőzés hatására bekövetkező biokémiai azonosságokat és különbségeket lehet kimutatni, hiszen erre a nemzetközi szakirodalomban szórványos adatok fellelhetők, amelyek azonban az összefüggésekre nem mutatnak rá. Az eddig közölt adatok között nem szerepelnek olyanok, amelyek az általam kitüzött célokat érintik, és mikroszaporított növényanyagra vonatkoznak. Tisztázni szeretnénk, hogy mely biokémiai változások kapcsolhatók az eltérő betegségformák kialakulásához.

A mikroszaporított növények bevonásának előnyei miatt a tesztelési módszer fejlesztésére, egy új, gyors és megbízható módszer kidolgozására azért van szükség, mert ezáltal jelentősen lecsökkenthető a vizsgálati idő, s a költségek is mérsékelhetők.

Munkám során az alábbi konkrét feladatok megoldását tűztem ki célul:

1. Burgonyafajták/klónok és almafajták fogékonyságának/ellenállóságának (biológiai stessztürésük fokozatainak) megállapítása mikroszaporított növényeken.

2. Rezisztens, mérsékelten fogékony és erősen fogékony fajták/klónok kiválasztása a biokémiai modellkísérletekhez.

3. A különböző baktériumos tünetformában (lágyrothadás, hajtáselhalás) végbemenő biokémiai folyamatok követése és összehasonlítása.

4. A fertőzést követő növényi válaszok (védekezési reakció) közötti azonosságok, vagy különbségek kimutatása biokémiai markerekkel.

5. Annak a kérdésnek a tisztázása, hogy a mikroszaporított növények alkalmasak-e a növények fogékonyságának/rezisztenciájának megállapítására.

6. Mikroszaporított növényeken alkalmazható gyors és megbízható tesztelési módszerek kidolgozása. 


\section{ANYAG ÉS MÓDSZER}

\subsection{Felhasznált anyagok}

4.1.1. Baktériumfajok azonosítása, biokémiai tulajdonságaik és virulenciájuk vizsgálata

A hazánkban Dr. Hevesi Mária által izolált és génbankban fenntartott fajokat/törzseket alkalmaztunk és az alábbi táblázatban (1. táblázat) bemutatott eltérő reakciók alapján elvégeztük a különböző fajok és alfajok előzetes ellenőrzését.

1. táblázat. Főbb diagnosztizáló tesztek az Erwinia, Dickeya és Pectobacterium fajok és alfajok elkülönítéséhez.

\begin{tabular}{|c|c|c|c|c|}
\hline $\begin{array}{l}\text { Kórokozó } \\
\text { Tesztek }\end{array}$ & $\begin{array}{l}\text { Pectobacterium } \\
\text { carotovorum } \\
\quad \text { subsp. } \\
\text { carotovorum }\end{array}$ & $\begin{array}{c}\text { Pectobacterium } \\
\text { carotovorum } \\
\text { subsp. atroseptica }\end{array}$ & $\begin{array}{r}\text { Dickeya } \\
\text { dadantii }\end{array}$ & $\begin{array}{l}\text { Erwinia } \\
\text { amylovora }\end{array}$ \\
\hline Erythromicin érzékenység & - & - & + & - \\
\hline $\begin{array}{l}\text { Redukáló anyagok } \\
\text { képződése szacharózból }\end{array}$ & - & + & + & + \\
\hline \begin{tabular}{|l|} 
Gáz képződése glükózból \\
\end{tabular} & - & - & + & + \\
\hline Pektát degradáció & + & + & + & - \\
\hline Indol képzés & - & - & + & - \\
\hline Gumók lágyrothadása & + & + & + & - \\
\hline \multirow{3}{*}{$\begin{array}{l}\text { Savképzés: } \\
\text { laktózból } \\
\alpha \text {-methyl-glükozidból } \\
\text { palatinózból }\end{array}$} & + & + & - & - \\
\hline & - & + & - & - \\
\hline & - & + & - & - \\
\hline
\end{tabular}

További biokémiai vizsgálatokat végeztünk a baktériumfajok azonosságának tisztázására (API 20E) és szénhidrát hasznosításának megállapítására (API 50CH) (Biomérieux, Marcy l’Etoile, France) kitek felhasználásával. Ezekbe a vizsgálatokba bevontunk az $D d$ egy virulens (1839) és egy avirulens (1679) törzsét is. Az összes izolátum esetében a kitek mintahelyeinek megtöltéséhez, a kitekhez tartozó speciális táptalajokhoz $10^{8} \mathrm{sejt} / \mathrm{ml}$ töménységű baktérium szuszpenziót használtunk. Mindkét gyorstesztet $36{ }^{\circ} \mathrm{C}$-on inkubáltuk és 24-48 óra elteltével értékeltük.

A további kísérletekben (növények fertőzése) a $P c c, D d$ és $E a$ baktérium virulens törzseit használtuk fel.

A burgonyát károsító baktérium törzsek virulenciáját pektinbontó képességüket kihasználva az alábbi gumóteszttel határoztuk meg:

Az alaposan megmosott burgonyagumókból szeleteket vágtunk, dugófúróval mindegyik közepébe kis mélyedést vájtunk, majd a korongokat steril, nedves szürőpapírt tartalmazó Petri csészékbe helyeztük. A gumókorongokon vájt mélyedésbe töltöttük a baktérium szuszpenziót 
(10 $\left.{ }^{8} \mathrm{sejt} / \mathrm{ml}\right) \mathrm{kb} .100 \mu \mathrm{l} /$ mélyedés mennyiségben úgy, hogy a lyuk megteljen, de a szuszpenzió ne csorogjon ki. A kontroll mintáknál a mélyedésekbe steril desztillált vizet töltöttünk. A szürőpapírokat $3 \mathrm{ml}$ steril desztillált vízzel nedvesítettük meg, majd a Petri csészéket lezártuk és 24 óráig $26^{\circ} \mathrm{C}$-on inkubáltuk a korongokat. A virulencia értékelése az alapján történt, hogy az inokuláció helyétől számítva milyen mértékben (átmérő) dezorganizálódott a gumószövet a 24 órás inkubációt követően (7. ábra).
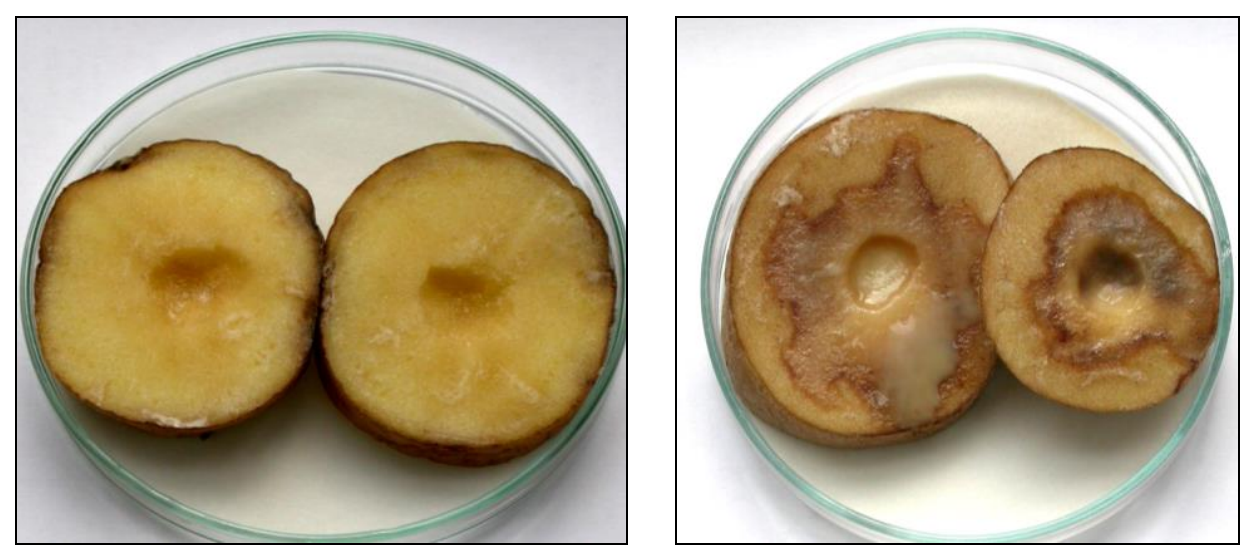

7. ábra. Gumóteszt eredménye virulens Dickeya dadantii 1839 (jobbra) és a desztillált vizes kontroll (balra) eredménye

A lágyrothadást nem okozó $E a$ virulenciáját pedig hiperszenzitív reakció segítségével teszteltük. A baktérium szuszpenziót $\left(10^{8} \mathrm{sejt} / \mathrm{ml}\right)$ a 'White Burley' dohánylevél szövetébe juttattuk injekciós tűvel. Majd 24 óra elteltével figyeltük a hiperszenzitív reakció kialakulását, azaz a gyors szöveti nekrózist (Klement, 1963) (8. ábra).

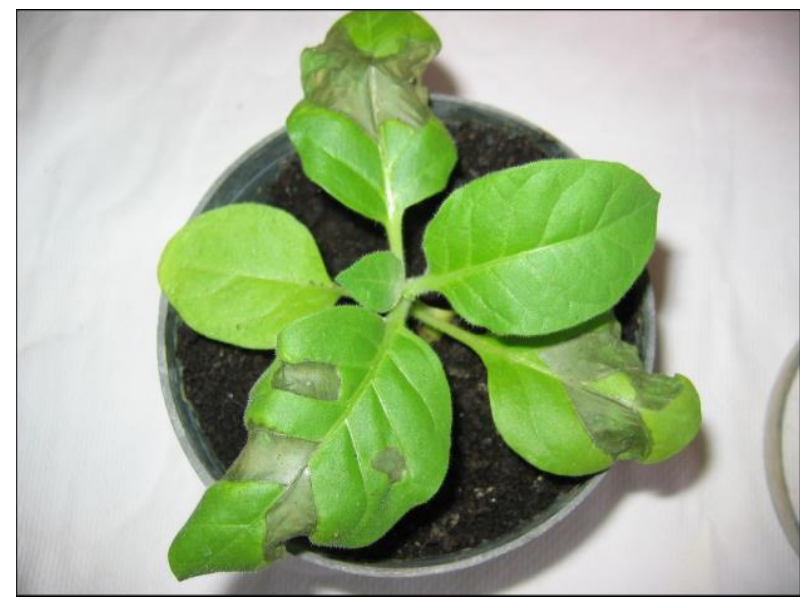

8. ábra. Erwinia amylovora virulenciájának ellenőrzése dohánynövényen hiperszenzitív reakció kialakulásával (Fotó: Honty Krisztina) 


\subsubsection{Burgonya- és almafajtákból előállított in vitro növények}

A mikroszaporított kísérleti növényanyagokat a Debreceni Egyetem ATK Nyíregyházi Kutatóintézetének Biotechnológiai Laboratóriumában állítottuk elő. A burgonyafajtákat és nemesítési klónokat a Biotechnológiai Laboratórium in vitro génbanki gyüjteményéből szaporítottuk fel.

Az almafajták esetében néhány fajta a Biotechnológiai Laboratórium génbanki anyagából származik, de néhány fajta esetében az in vitro felszaporítást megelőzte az in vitro kultúrába vitel. 2012 februárjában a Budapesti Corvinus Egyetem Gyümölcstermő Növények Tanszékének kísérleti telepéről behozott vesszők meghajtatásával megkezdtük hét almafajta ('Red Fuji', 'Freedom', 'Húsvéti rozmaring', 'Jonagold', 'Hesztia', 'Idared' és 'Tenroy’ (Royal Gala)) in vitro kultúrájának létrehozását. A kísérletben államilag elismert multirezisztens fajta, történelmi almafajta és jelenleg is termesztésben lévő fajta egyaránt szerepelt.

\subsection{A fertőzések és tünetértékelések vizsgálati módszerei}

A burgonyát károsító Erwinia fajokkal végzett in vitro fertőzéseket a DE ATK Nyíregyházi Kutatóintézet Biotechnológiai Laboratóriumában dolgoztuk ki. In vivo burgonyafertőzések Vlasov és Pereverzev módszerével (1989) történtek.

Az Ea-val végzett in vitro hajtásfertőzések esetében Hevesi et al. (2000) által kidolgozott módszert alkalmaztuk.

A kiválasztott izolátumokkal 2003 és 2008 között végeztünk fertőzéseket in vitro burgonyahajtásokon, in vitro gumókon (mikrogumó) és üvegházi gumókon (primer gumó). Alma esetében in vitro hajtásfertőzések 2012 és 2013-ban történtek.

\subsubsection{Burgonyafajták hajtásfertőzése in vitro körülmények között}

A kísérletekbe összesen 13 burgonya genotípust vontunk be: 77365/103, 98/91, 136/92, 36/92, 34/85, 736/82, 1469/83, 77399/514, 'Desiree', 'Réka', 'Cleopátra', 'Rachel’ és 'Boró'.

A fertőzési módszer leírása:

In vitro burgonyanövények nevelése egyedenként (kémcsőben) 3 hétig hormonmentes MS táptalajon, napi 16 órás, $105 \mu \mathrm{mól} \mathrm{m}^{-2} \mathrm{~s}^{-1}$ megvilágításon, $22{ }^{\circ} \mathrm{C}$ hőmérsékleten nevelőhelyiségben történt.

A kísérletekben három hetes in vitro burgonyanövényeket fertőztünk. A fertőzésekhez az $P c c$ és $D d 10^{8}$ sejt/ml töménységű szuszpenzióját használtuk. A fertőzések steril 
körülmények között, egy derékszögben meghajlított csipesz hegyével történtek úgy, hogy a növény szárának közepét szúrtuk meg, melyet előzőleg a baktériumszuszpenzióba mártottunk. A fertőzés közben a kémcsövet lefelé fordítottuk, hogy a baktérium szuszpenzióból ne kerülhessen a táptalajra. A kontroll kezelés esetében a növényeket steril desztillált vízbe mártott csipesszel szúrtuk meg (9. ábra).

A megfertőzött növényeket tartalmazó lezárt kémcsöveket visszahelyeztük nevelöhelyiségbe.

$>$ A fertőzést követő hetedik napon megfigyeltük a szár- és levéltüneteket (mm-ben mért üveges, átlátszó szár, a levél hervadt); a levéltünetek alapján betegségfokot számítottunk, melynek értéke alapján meghatároztuk, hogy az adott burgonyafajta milyen érzékenységi osztályba sorolható: erősen fogékony, mérsékelten fogékony, vagy nem fogékony a fertőző baktériummal szemben.

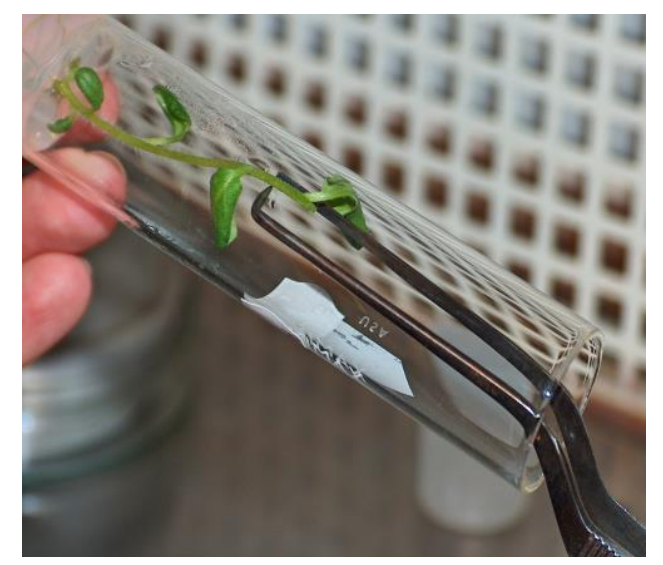

9. ábra. In vitro hajtásfertőzés módszere burgonyánál

Az in vitro burgonyanövények fertőzését mind a $P c c$, mind a $D d$ esetén három független kísérletben végeztük, alkalmanként 20-25 db fertözött és 5 db kontroll növénnyel dolgoztunk genotípusonként.

Baktérium sejtszám meghatározása:

A baktérium - fertőzött növényi szövetekben való - szaporodásának mértékéről a baktériumsejtek visszaizolálásával győződtünk meg. Összesen három helyről vettünk mintát, ahonnan 1 cm-es szárdarabokat metszettünk ki:

- az inokulációs ponttól számítva felfelé és lefelé is 0,5 cm-t (szúrás környéke (SZ))

- a szúrás környéki rész feletti $1 \mathrm{~cm}-\mathrm{s}$ szárrész (szúrás felett $(\mathrm{F})$ )

- a szúrás környéki rész alatti 1 cm-s szárrész (szúrás alatt (A))

Egy mintákhoz genotípusonként $3 \mathrm{db} 1 \mathrm{~cm}$ hosszú hajtásdarabokat használtuk fel. A fertőzött szárrészt steril dörzsmozsárban hajtásdarabonként $100 \mu \mathrm{l}$ steril desztillált vízzel homogenizáltuk, 
majd ebböl tízes lépték szerint hígítási sort készítettünk. A hígítási sorból három hígítást szélesztettünk ki. Pcc esetében $10^{-7}, 10^{-8}, 10^{-9}$, míg $D d$ esetében $10^{-6}, 10^{-7}, 10^{-8}$. Ezek voltak azok a hígítások, ahol szabad szemmel jól számolhatóak voltak a telepek. A hígításokból Nutrient agarra cseppentettünk $100 \mu \mathrm{l}-\mathrm{t}$, majd üvegbottal szélesztettük. A mintákat 48 h-ig 26 ${ }^{\circ} \mathrm{C}$-on inkubáltuk, majd a kifejlődött kolóniákat megszámoltuk.

In vitro burgonyanövények fogékonyságának értékelése:

A növényeken a tüneteket egy, három és hét nap után értékeltük. Az alábbi skála alapján minden növény kapott egy értékszámot, majd a kapott értékekből fertőzési indexet $\left(F_{i}\right)$ számoltunk.

Tünetek értékelésének skálája:

1: tünetmentes

2: a levelek $1-25 \%$-a hervadt

3: a levelek $26-50 \%$-a hervadt

4: a levelek $51-75 \%$-a hervadt

5: a levelek 76-100\%-a hervadt

Fertőzési index $\left(\mathbf{F}_{\mathbf{i}}\right)$ számítása az alábbi képlettel történt:

$$
\begin{gathered}
\Sigma\left[\left(\mathrm{N}_{1} \times 1\right)+\left(\mathrm{N}_{2} \times 2\right)+\left(\mathrm{N}_{3} \times 3\right)+\left(\mathrm{N}_{4} \times 4\right)+\left(\mathrm{N}_{5} \times 5\right)\right] \\
\mathrm{F}_{\mathrm{i}}=\mathrm{N} \\
\mathrm{N}_{1-5} \text { : adott skálafokhoz tartozó beteg növények száma } \\
\Sigma \mathrm{N} \text { : összes megfigyelt növény }
\end{gathered}
$$

A fertőzési index alapján a vizsgált klónokat különböző fogékonysági csoportokba soroltuk:

Pectobacterium carotovorum subsp. carotovorum esetén

$1 \leq \mathrm{F}_{\mathrm{i}} \leq 2: \quad$ rezisztens

$2<\mathrm{F}_{\mathrm{i}} \leq 3: \quad$ mérsékelten rezisztens

$3<\mathrm{F}_{\mathrm{i}} \leq 3,5$ : mérsékelten fogékony

$3,5<\mathrm{F}_{\mathrm{i}} \leq 4,5$ : fogékony

$4,5<\mathrm{F}_{\mathrm{i}}$ : $\quad$ erősen fogékony

Dickeya dadantii esetén

$1 \leq \mathrm{F}_{\mathrm{i}} \leq 1,3: \quad$ rezisztens

$1,3<\mathrm{F}_{\mathrm{i}} \leq 1,6: \quad$ mérsékelten rezisztens

$1,6<\mathrm{F}_{\mathrm{i}} \leq 2$ : mérsékelten fogékony

$2<\mathrm{F}_{\mathrm{i}}$ : erősen fogékony 


\subsubsection{Burgonya mikrogumó fertőzése in vitro körülmények között}

A burgonya mikrogumókat (10. ábra) a fertőzési kísérleteket megelőző évben (2003) kezdtük előállítani. Leszedésüket követően egy hétig szobahőmérsékleten parásodtak. 6-10 mm-es frakciójú gumókon végeztük a fertőzési kísérleteket. Az inokulációhoz továbbra is a $P c c$ és $D d$ 24 órás tenyészetéből készült $10^{8}$ sejt/ml töménységü szuszpenzióját használtuk. A kísérletbe bevont genotípusok: 77365/103, 98/91, 136/92, 36/92, 34/85, 736/82, 1469/83, 77399/514, 'Desiree', 'Réka', 'Gülbaba', 'Rachel' és 'Boró'. A gumókat baktériumszuszpenzióba mártott steril injekcióstűvel megszúrtuk, majd steril műanyag Petri csészébe, steril szürőpapírra helyeztük, amelyet steril desztillált vízzel (2 ml/petricsésze) megnedvesítettünk. A kontroll kezelés során steril desztillált vizet használtunk inokulumként. A lezárt Petri csészéket $26^{\circ} \mathrm{C}-\mathrm{ra}$ termosztátba helyeztük. Kísérletenként $25 \mathrm{db}$ mikrogumót fertőztünk genotípusonként, ebből 5 db képviselte a kontroll csoportot.

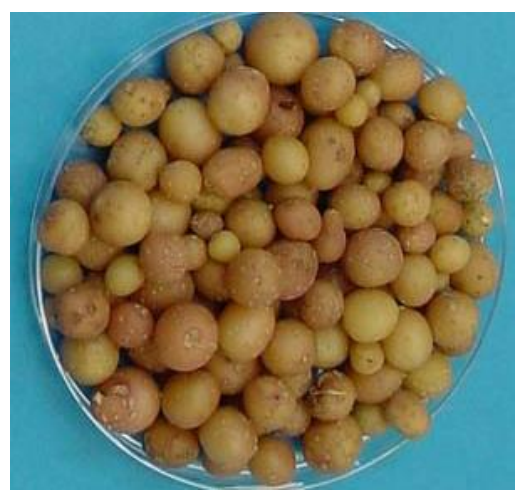

10. ábra. In vitro 'Desiree’ burgonyagumók (Fotó: Borbély Ferenc)

In vitro gumók fogékonyságának értékelése:

Az értékelés a fertőzést követő első, harmadik és hetedik napon történt. A gumókat a szúrás mentén felvágtuk és a gumószövet felbomlásának arányában értékeltük a tüneteket.

A következő skálát használtuk:

1- nincs tünet

2- gumó $25 \%$-a elrothadt

3- gumó $50 \%$-a elrothadt

4- gumó $75 \%$-a elrothadt

5- a teljes gumó elrothadt.

A tünetek alapján fertőzési indexet számítottunk, az így nyert értékek szerint a vizsgált klónokat különböző fogékonysági csoportokba soroltuk: 
Pectobacterium carotovorum subsp. carotovorum esetén

$$
\begin{array}{ll}
1 \leq F_{i} \leq 3: & \text { rezisztens } \\
3<F_{i} \leq 4,2: & \text { mérsékelten fogékony } \\
4,2<F_{i}: & \text { erösen fogékony }
\end{array}
$$

Dickeya dadantii esetén

$1 \leq \mathrm{F}_{\mathrm{i}} \leq 2: \quad$ rezisztens

$2<\mathrm{F}_{\mathrm{i}} \leq 3,5: \quad$ mérsékelten rezisztens

$3,5<\mathrm{F}_{\mathrm{i}} \leq 4,2: \quad$ mérsékelten fogékony

$4,2<\mathrm{F}_{\mathrm{i}}$ : $\quad$ erősen fogékony

\subsubsection{Primer burgonyagumó fertőzése üvegházi körülmények között}

$P c c$ és $D d$ virulens törzseinek $10^{8}$ sejt/ml szuszpenzióját használtuk a kísérletek során, melyekben továbbra is 13 burgonya genotípust: 77365/103, 98/91, 136/92, 36/92, 34/85, 736/82, 1469/83, 77399/514, 'Desiree', 'Réka', 'Gülbaba', 'Rachel' és 'Boró' vizsgáltunk meg. A kísérletekhez felhasznált kórokozómentes primer gumókat üvegházban állítottuk elő, izolátor alatt.

Az inokuláció során Vlasov és Pereverzev módszerét (1989) alkalmaztuk (11. ábra):

> Mintánként 3-5 egészséges gumót folyóvíz alatt megtisztítottunk, megszárítottunk és 96\%-os etil-alkohollal áttöröltük.

> Dugóhúzó segítségével 10 mm átmérőjü hengereket vájtunk ki, majd feldaraboltuk $1 \mathrm{~cm}$ hosszúságú darabokra, minimum 20-25 db-t (+ 5 kontroll) mintánként.

$>\mathrm{Az}$ inokuláció előtt minden korongot lemértünk, majd steril Petri csészébe helyeztük megnedvesített szürőpapírra (5db korong/ Petri csésze).

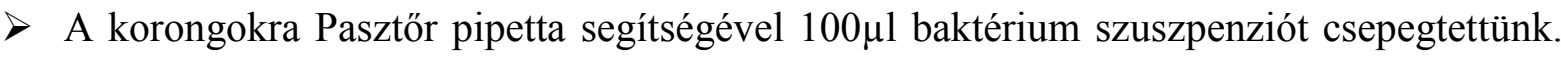
A kontroll kezelésben steril desztillált vizet használtunk.

$>$ A fertőzést követően a Petri csészéket inkubátorba raktuk $26{ }^{\circ} \mathrm{C}$-ra $24-26$ órára.

$>$ Másnap az elrothadt növényi részt lemostuk és az egészséges növényi szövet tömegét visszamértük.
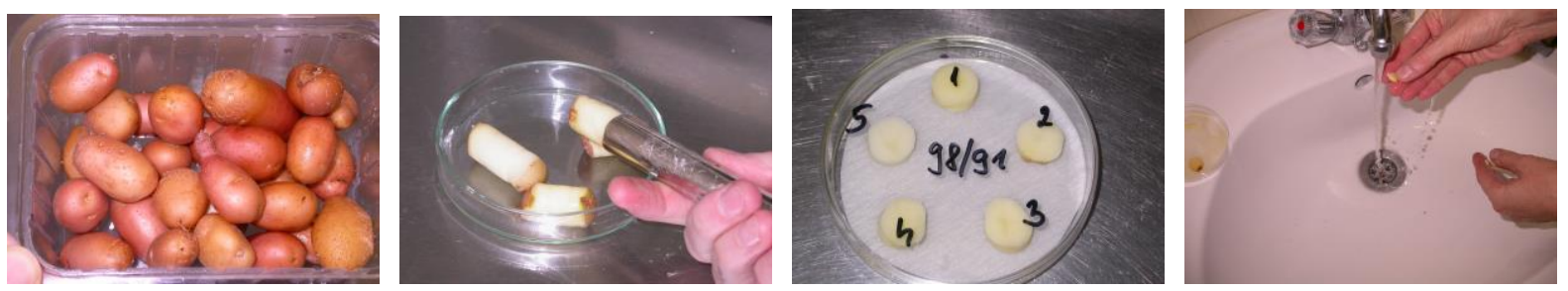

11. ábra. Primer burgonyagumók fertőzési módszere 
Primer burgonyagumók fogékonyságának értékelése:

A fogékonyság mértékét egy öt fokozatú skála segítségével határoztuk meg, melynek alapja az a tömegkülönbség, mely a burgonyakorongok tömegének az inokuláció előtti és utáni mérésekből adódtak. Eredményeinket az egészséges szövet tömegének arányában \%-ban fejeztük ki.

A következő skálát használtuk mindkét baktériumfaj esetében:

1- $0-5,0 \%$ erősen fogékony

2- 5,1-10,0\% fogékony

3-10,1-20,0\% mérsékelten fogékony

4- 20,1-30,0\% mérsékelten rezisztens

5- $30,1 \%$ felett rezisztens

\subsubsection{Mikroszaporított almafajták hajtásfertőzése}

Vizsgálatainkat hét almafajta: 'Red Fuji', 'Freedom', 'Húsvéti rozmaring', 'Jonagold', 'Hesztia', 'Idared' és 'Tenroy' (Royal Gala) négy hetes in vitro növényein végeztük. Kísérletenként 50-60 $\mathrm{db}$ fertőzött növénnyel és 8-10 db kontroll növénnyel dolgoztunk. Az in vitro növényeket a Debreceni Egyetem ATK Nyíregyházi Kutatóintézetének Biotechnológiai Laboratóriumában állítottuk elő. A fertőzések $E a 24$ órás tenyészetének szuszpenziójába $\left(10^{8} \mathrm{sejt} / \mathrm{ml}\right)$ mártott ollóval, felülről számított második kifejlett levelek bevágásával történtek (12. ábra).

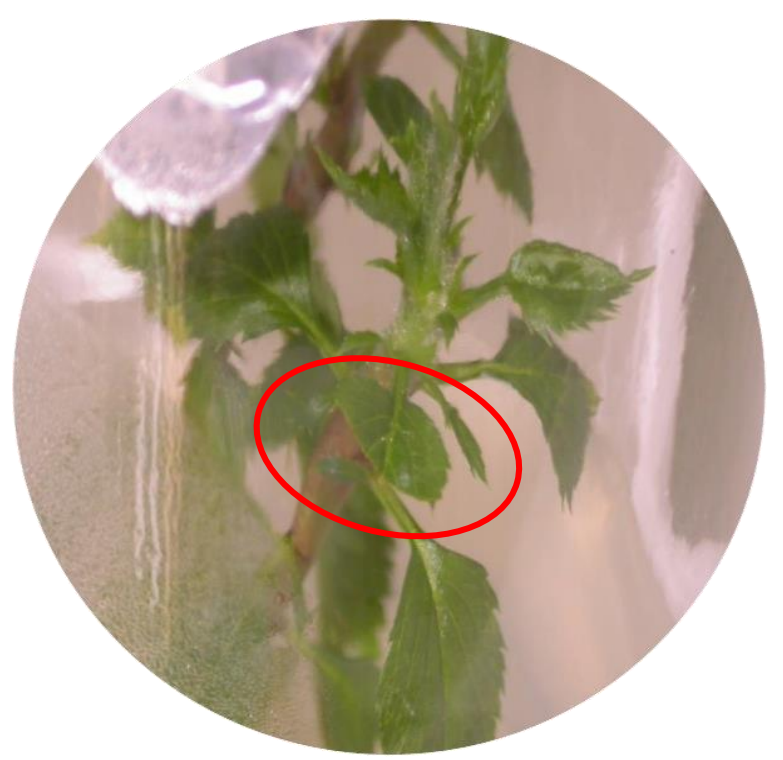

12. ábra. Hajtásfertőzés módja in vitro almanövényeknél 
Baktérium sejtszám meghatározása:

A baktérium szaporodásának mértékét a fertőzött növényi szövetben a baktériumsejtek visszaizolálásával végeztük alma esetében is. $1 \mathrm{~cm}$-es szárdarabot metszettünk ki az inokulációs ponttól, vagyis a félbevágott levél nyelének szárhoz illeszkedésétől számítva felfelé és lefelé is 0,5 cm-t. Egy mintákhoz fajtánként három darab, $1 \mathrm{~cm}$ hosszú hajtásdarabot használtuk fel. A hajtásdarabokat mintánként $100 \mu$ steril desztillált vízzel homogenáltuk steril dörzsmozsárban, majd ebből tízes lépték szerint hígítási sort készítettünk. A hígításokból Nutrient agarra cseppentettük $100 \mu \mathrm{l}$-t, majd üvegbottal szélesztettük. A mintákat 48 h-ig $26^{\circ} \mathrm{C}$-on inkubáltuk, majd a kifejlődött kolóniákat megszámoltuk.

In vitro almanövények fogékonyságának értékelése:

A tüneteket a fertőzést követő második, ötödik és nyolcadik napon értékeltük. A betegség mértékét a bevágott levél, a tovább fertőződött levelek, levélerek és a hajtás elbarnulásának mértéke alapján értékeltük egy öt fokozatú skála segítségével Gill (2000) módszere szerint (13. ábra).

0 - nincs tünet, esetleg a vágás felszínén látható csekély elbarnulás

1 - a barnulás a megvágott levél főerére is átterjed

2 - elbarnul a levélnyél is, illetve a fóér mentén a levél többi részére is kiterjed a barnulás

3 - a vágott levéllel szomszédos levelek föere és levélnyele is elbarnul, valamint a levelek lekonyulnak

4 - a szomszédos levelekben tovább terjed a barnulás, a megvágott levél alatt a szár is elbarnul

5 - a teljes hajtás elbarnul, baktérium nyálkacseppek jelennek meg a száron 


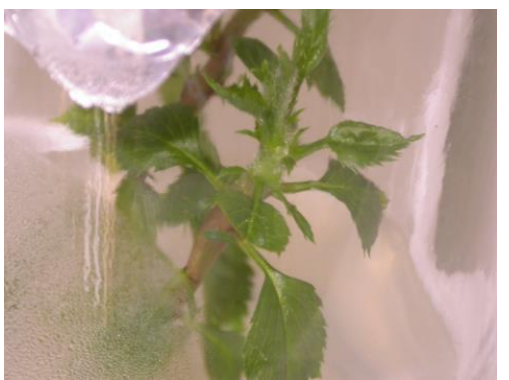

0

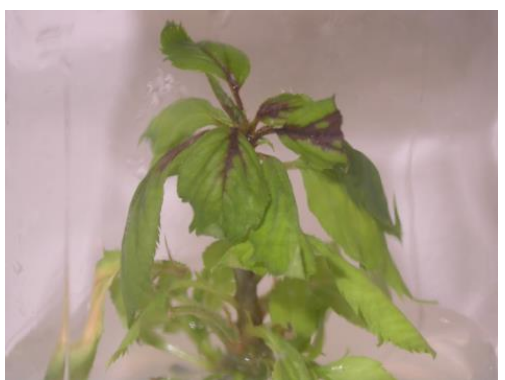

3
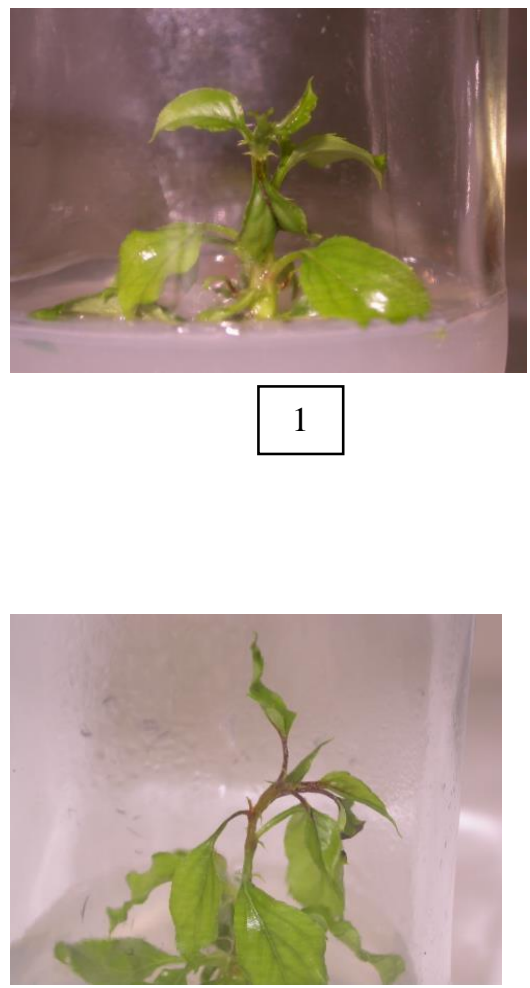

4

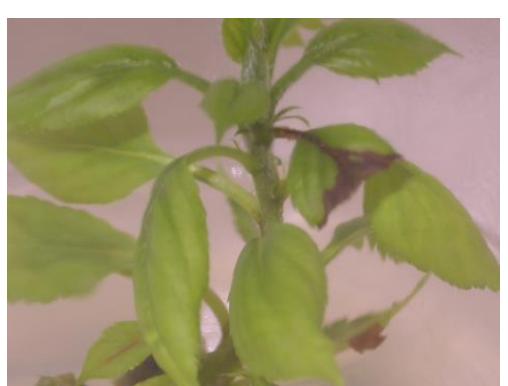

2

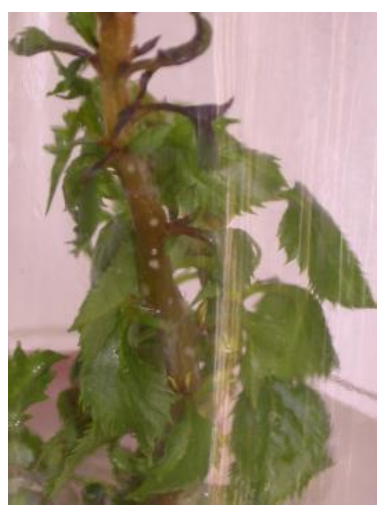

5

13. ábra. A betegség tüneteinek erőssége a hajtásokon (fertőzési index)

Fertőzési index $\left(\mathbf{F}_{\mathbf{i}}\right)$ számítása az alábbi képlettel történt:

$$
\begin{gathered}
\Sigma\left[\left(\mathrm{N}_{1} \times 1\right)+\left(\mathrm{N}_{2} \times 2\right)+\left(\mathrm{N}_{3} \times 3\right)+\left(\mathrm{N}_{4} \times 4\right)+\left(\mathrm{N}_{5} \times 5\right)\right] \\
\Sigma \mathrm{N} \\
\mathrm{N}_{1-5} \text { : adott skálafokhoz tartozó beteg növények száma } \\
\Sigma \mathrm{N} \text { : összes megfigyelt növény }
\end{gathered}
$$

Fajtánként átlagoltuk a mérési adatokat. Az ötödik napon megfigyelt tüneteket figyelembe véve a számított $\mathrm{F}_{\mathrm{i}}$ érték alapján a fajták jellemzéséhez négy fogékonysági csoportot különítettünk el:

$0 \leq \mathrm{F}_{\mathrm{i}} \leq 2,0: \quad$ rezisztens

$2,0<\mathrm{F}_{\mathrm{i}} \leq 2,4: \quad$ mérsékelten rezisztens

$2,4<\mathrm{F}_{\mathrm{i}} \leq 3$ : mérsékelten fogékony

$3<\mathrm{F}_{\mathrm{i}}$ : erősen fogékony 


\subsection{Biokémiai vizsgálatok anyaga és módszerei}

4.3.1. Kísérletbe bevont növényfajok/fajták és mintavételek

$\mathrm{Az}$ in vitro növényfertőzési kísérletek eredményei alapján választottuk ki a biokémiai vizsgálatokhoz a következő genotípusokat:

Pectobacterium carotovorum subsp. carotovorum esetén:

- rezisztens: 77365/103 klón

- mérsékelten fogékony: 36/92 klón

- erősen fogékony: 98/91 klón

Dickeya dadantii esetén:

- rezisztens: 34/85 klón

- mérsékelten fogékony: 'Réka'

- erősen fogékony: 'Boró'

Erwinia amylovora esetén:

- rezisztens: 'Freedom'

- mérsékelten fogékony: 'Húsvéti rozmaring'

- erősen fogékony: 'Tenroy' (Royal Gala)

A biokémiai vizsgálatok során a mintavételi helyek kijelölése a visszaizoláláskor vett mintákhoz hasonlóan történt.

A burgonyanövényeknél három helyről vettünk mintát:

- a szúrás környéki részből, ez az inokulációs pont alatt és feletti 1-1 cm-es szárdarabot takarta (SZ),

- szúrás környéki rész feletti (szúrás feletti) 2 cm-s szárrészt (F) és

- a szúrás környéki rész alatti (szúrás alatti) szárrészt is, szintén $2 \mathrm{~cm}$ hosszúságút (A).

Alma esetében egy helyről vettünk mintát. Összesen $2 \mathrm{~cm}$-es szárdarabot metszettünk ki az inokulációs ponttól - félbevágott levél nyelének szárhoz illeszkedése - számítva lefelé haladva.

\subsubsection{Vizsgálati módszerek}

4.3.2.1. A peroxidáz enzimaktivitás spektrofotometriás meghatározása

A peroxidáz (POD) enzimaktivitás meghatározása a Budapesti Corvinus Egyetem Élelmiszertudományi Kar Alkalmazott Kémia Tanszékén, Stefanovitsné Dr. Bányai Éva irányításával történt.

Az enzimaktivitások méréséhez kb. 200 mg mintát mértünk be hütött dörzsmozsárba és 800 $\mu l$ hütött $0,1 \mathrm{M}$ Tris- $\mathrm{HCl}$ puffer $(\mathrm{pH}=7,8)$ és kvarchomok hozzáadásával eldörzsöltük. A 
mintákat $13000 \mathrm{rpm}$ fordulatszámon 18 percig $4{ }^{\circ} \mathrm{C}$-on centrifugáltuk, majd a felülúszóból határoztuk meg a peroxidáz aktivitást.

Az így nyert növényi kivonatból Shannon et al. (1966) spektrofotometriás módszere alapján mértük a POD aktivitást, $\mathrm{H}_{2} \mathrm{O}_{2}$, mint szubsztrát és ortodianizidin, mint kromogén reagens $(\varepsilon=11,3)$ jelenlétében. Az abszorbancia növekedését 460 nm-n mértük (Varian DMS $100 \mathrm{~S}$ UVVisible Spektrophotometer). Az enzimaktivitást U/mg egységben adtuk meg friss súlyra vonatkoztatva.

\subsubsection{Szénhidráttartalom meghatározás}

Mintánként $300 \mathrm{mg}$ in vitro burgonyanövény szárat, valamint $100 \mathrm{mg}$ in vitro almahajtás szárat dörzsmozsárban folyékony nitrogénnel homogenáltuk. A vizsgálat időpontjáig a mintákat -80 ${ }^{\circ} \mathrm{C}$-on, ultramélyhütőben tároltuk. A vizsgálat során a mintákhoz $1 \mathrm{ml}$ desztillált vizet adtunk oldószerként, majd rázógépben egy éjszakán át rázattuk azokat. Az így előkészített mintákat 5 percen keresztül 15000 fordulat/perces fordulatszámon centrifugáltuk (Hettich 23R). Ezt követően a felülúszót pipettával leszívtuk, majd 0,45 $\mu \mathrm{m}$ átmérőjü MILLEX ${ }^{\circledR}-H N$ Syringe Driven Filter Unit (SLHN 013 NL, Millipore Ltd. 290 Concord Road, Billerica, MA 01821, USA) szürőn átszürtük.

HPLC berendezés: a mérések során a Waters HPLC berendezés (Waters Corporation 34 Maple Street Milford, MA 01757 USA) a következő hardverekből állítottuk össze: 2414 Refractive Index Detector, 1525 Binary HPLC Pumpa, Colonna termosztát, 717plus automata injektor. A berendezés felügyeletét és irányítását EMPOWERTM 2 software program végezte.

A cukrok szétválasztása Sugar-PakTM oszlopon történt, melyet $90 \quad{ }^{\circ} \mathrm{C}$-on oszloptermosztátban tartottuk. A mozgó fázis 0.0001 M Ca-EDTA [304695-78-1] tartalmú víz volt. Az áramlási sebesség $0.5 \mathrm{ml} /$ perc, ilyen áramlás mellett $450 \pm 10$ psi nyomás alakult ki az oszlopon. A detektálás 30 percig történt. Az injektálási mennyiség $20 \mu 1$ volt. A retenciós idő: szacharóz 8,3 perc, glükóz 10,8 perc, fruktóz 11,77 perc, szorbitol 15,4 perc.

A méréseket a BCE Gyümölcstermő Növények Tanszék HPLC laboratóriumában lévő berendezéssel végeztük Dr. Végvári György irányításával.

A vizsgálataink során kapott valamennyi adat statisztikai kiértékelését egytényezős varianciaanalízissel végeztük SPSS 13.0 for Windows programcsomag segítségével. A homogén csoportok képzése Tukey-teszttel történt. 


\section{EREDMÉNYEK}

\subsection{Az API 20E és API 50CH tesztetek eredményei}

Mindkét kit módszere színváltozás megfigyelésén alapszik. Az API20E kit értékelése során az eredményeket a gyártó által rendelkezésünkre bocsátott pozitív és negatív minta-tesztcsíkok alapján értékeltük (14. ábra). Ea esetén pozitív reakciót kaptunk a $\beta$-galaktozidáz, citrát hasznosítás, acetoin termelés, valamint a glükóz, mannit, szorbit, szacharóz, arabinóz vizsgálatokban. Pcc esetén pozitív volt a lizin-dekarboxiláz és az acetoin termelésére irányuló vizsgálatok. A virulens $D d$ az acetoin termelésre, a gelatinázra, az inozitra és a szorbitra adott pozitív reakciót, míg az avirulens $D d$ estében pozitív lett a lizin-karboxiláz és az acetoin termelés.

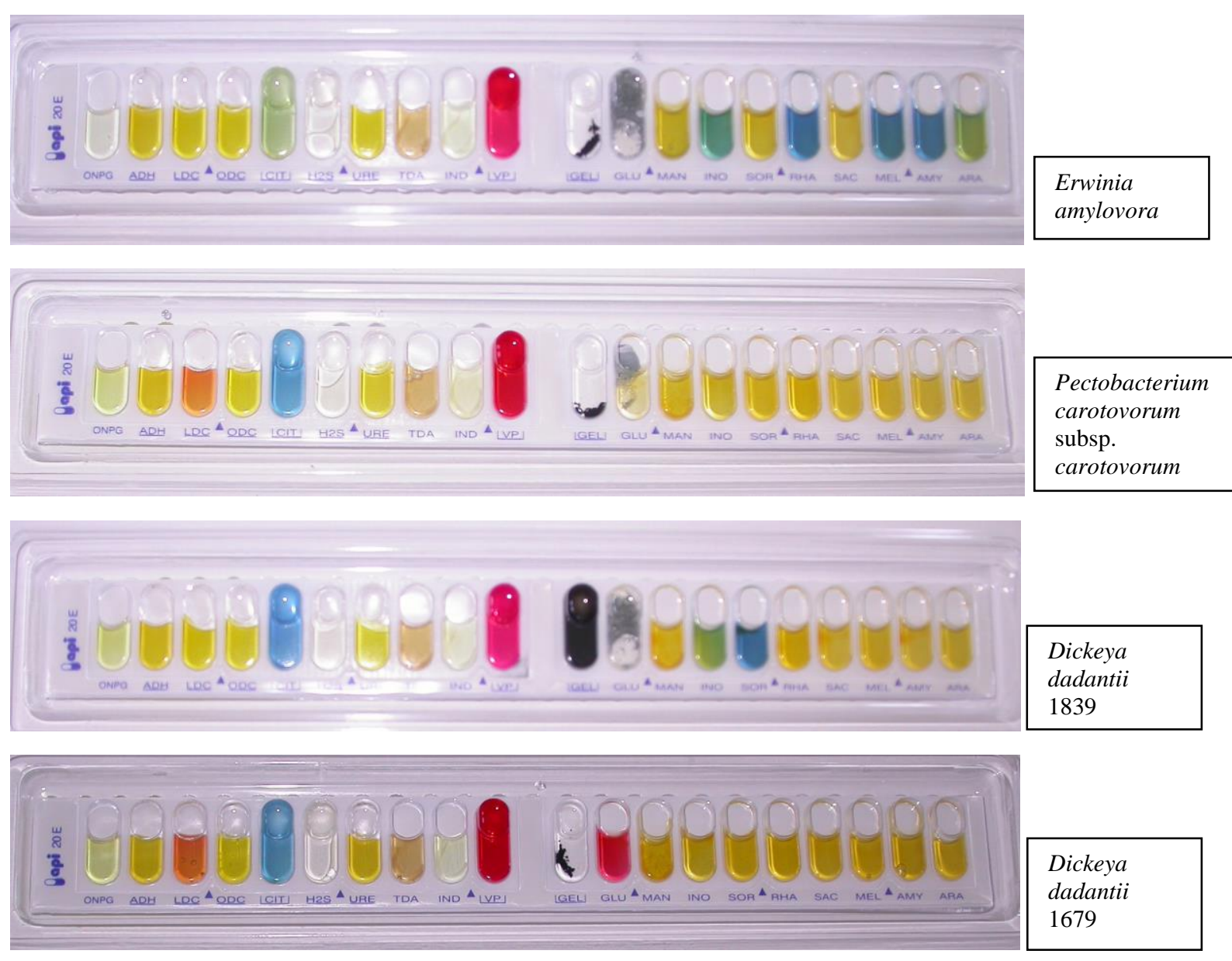

14. ábra. A kísérletbe vont baktériumfajok/törzsek biokémiai tulajdonságai API 20E tesztcsíkok alkalmazásával 
Az API 50CH kit értékelése során, ha az adott baktérium hasznosítja az adott szénhidrátot, akkor az eredeti piros színü oldat sárgára változik, míg a zselatinbontás esetében pozitív teszt során elfolyósítja a zselatint és fekete színreakció lép fel (15. ábra). A 49 különböző szénhidrátból kiemelném a számunkra legfontosabbakat, a glükózt, fruktózt, szacharózt és szorbitolt, melyet valamennyi vizsgált baktérium hasznosít.
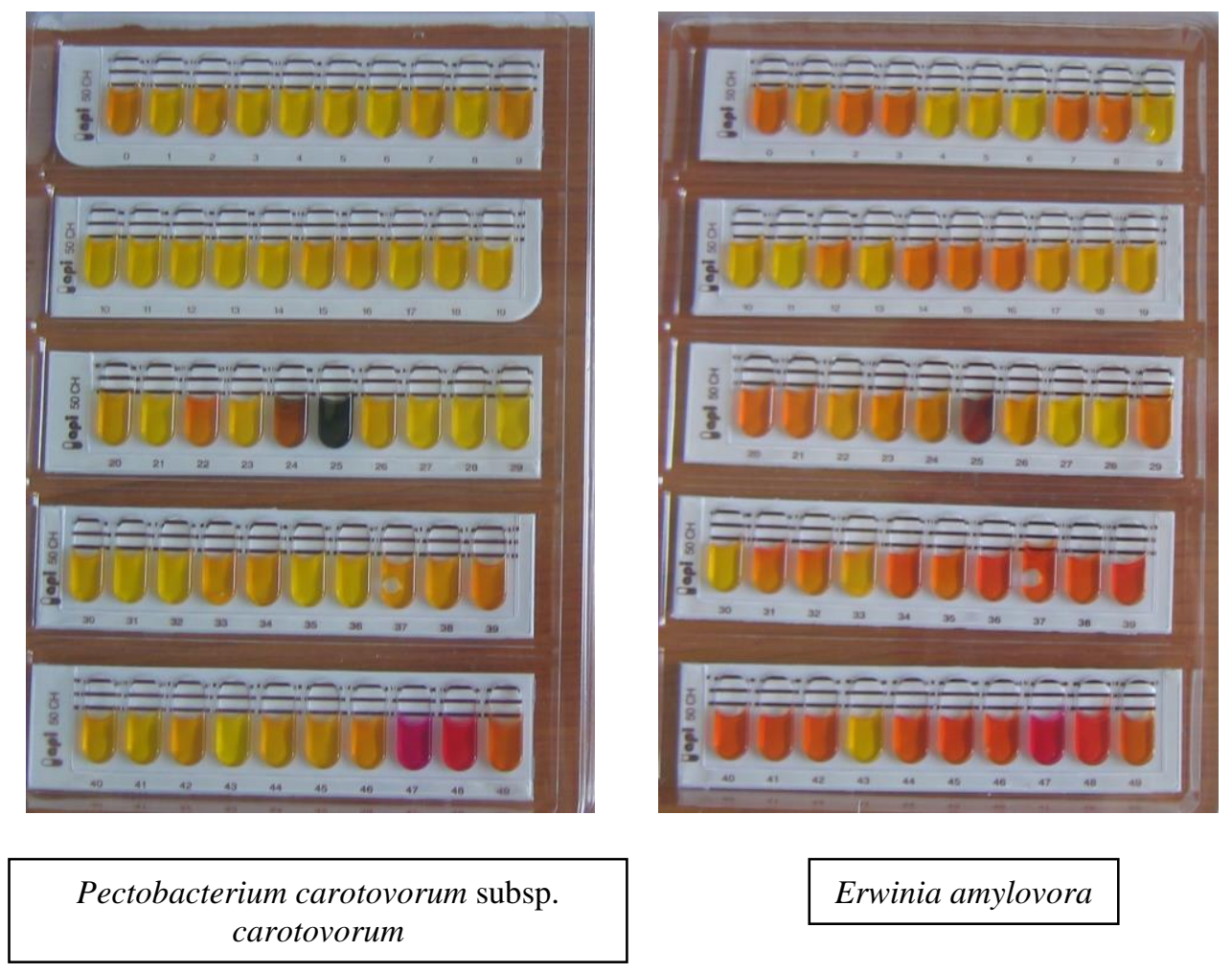

Erwinia amylovora
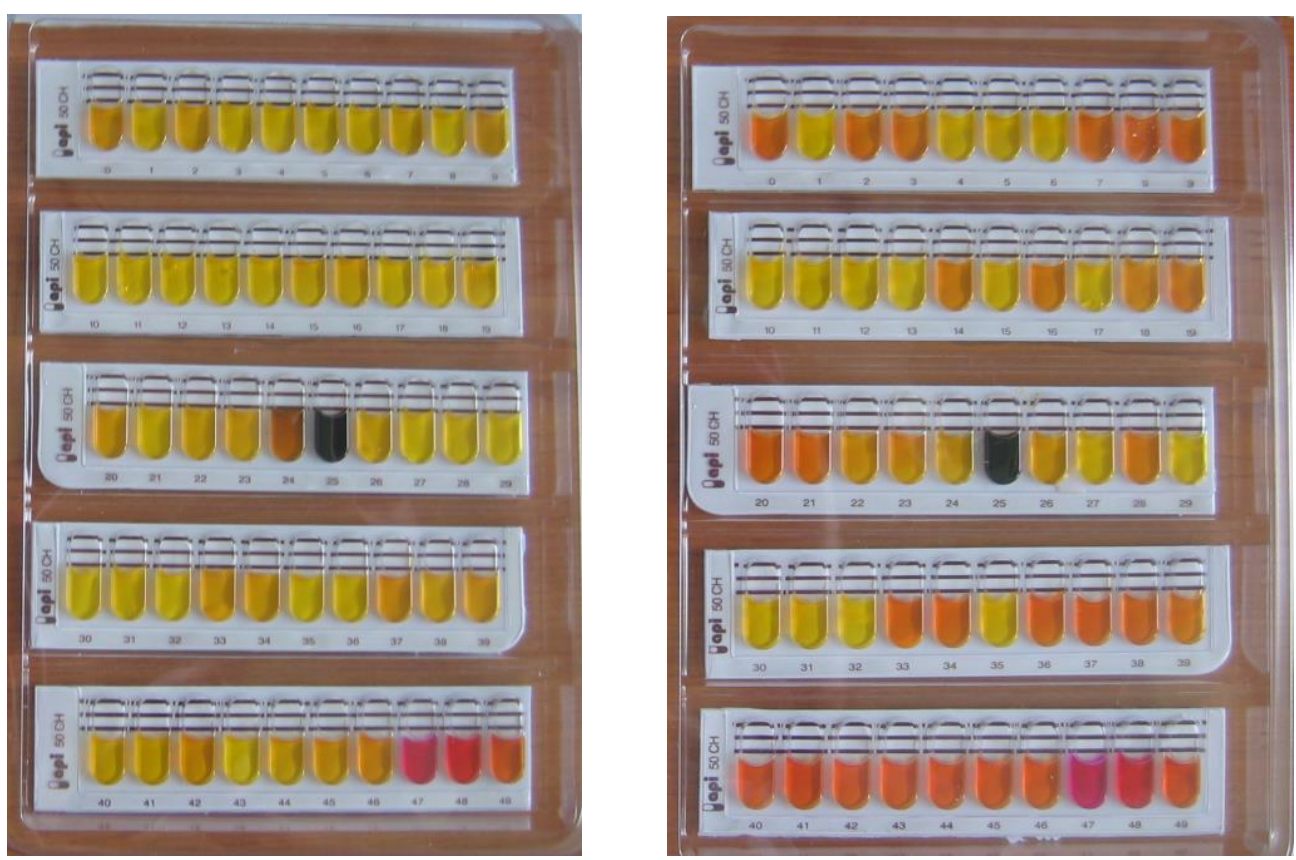

Dickeya dadantii 1679

Dickeya dadantii 1839

15. ábra. A kísérletbe vont baktériumfajok/törzsek cukorhasznosítása API 50CH tesztcsíkok alkalmazásával 


\subsection{Burgonyafajták fogékonysága a baktériumfajokkal szemben}

\subsubsection{In vitro burgonyafajták fogékonysága a hajtásfertőzés alapján}

Az in vitro növények betegségfokozatait (rezisztens, mérsékelten rezisztens, mérsékelten fogékony, erősen fogékony) a fertőzést követő hetedik napra kifejlődött tüneteket alapján mutatom be mind a $P c c$, mind az $D d$ esetében. A két baktériumfaj a hajtásokon hasonló betegségtüneteket okozott. Az alábbiakban a fontosabb betegségkategóriákra jellemző, vizuálisan észlelhető tünetformák láthatók.

A desztillált vízzel történt kontroll kezelések esetében valamennyi növény a tünetmentes kategóriába tartozott. A növények egészségesek, sem levél, sem szártünet nem mutatkozik rajtuk. A szúrás helye észrevehető, de beszáradt (16. ábrán bekarikázva).

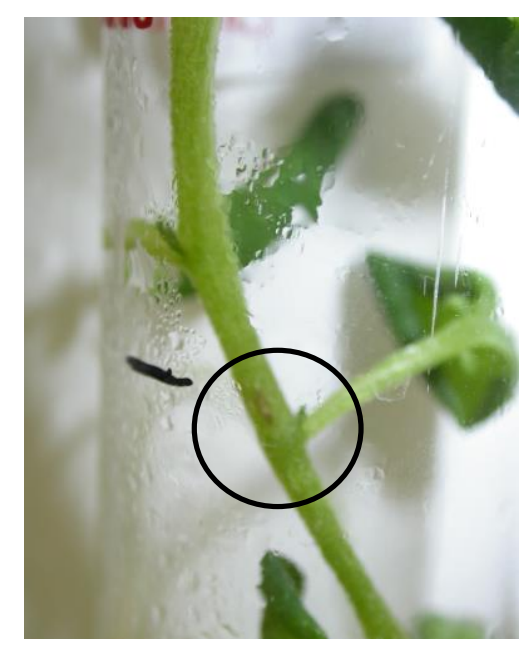

16. ábra. Kontroll kezelésü, tünetmentes 'Cleopátra' $\left(\mathrm{F}_{\mathrm{i}}=1,0\right)$

A rezisztens klónok esetében nagymértékü levélkárosodás nem volt jellemző, legfeljebb a szúrás alatti vagy feletti levél volt hervadt. Szártüneteket nem lehet megfigyelni, viszont a szúrás helye látszik (17. ábra).

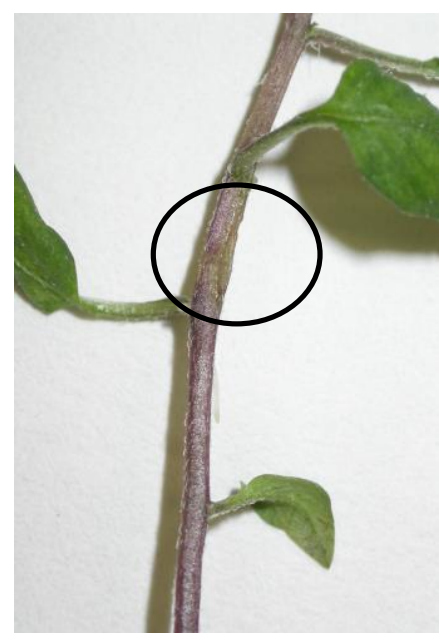

17. ábra. A 77365/103, mint rezisztens klón in vitro hajtásain jelentkező tünetek $\left(\mathrm{F}_{\mathrm{i}}=1,63\right)$ 
A mérsékelten rezisztens fajta esetén a szúrás helye látszik, több levél elhervadt, de szártüneteket nem lehetett megfigyelni (18. ábra).

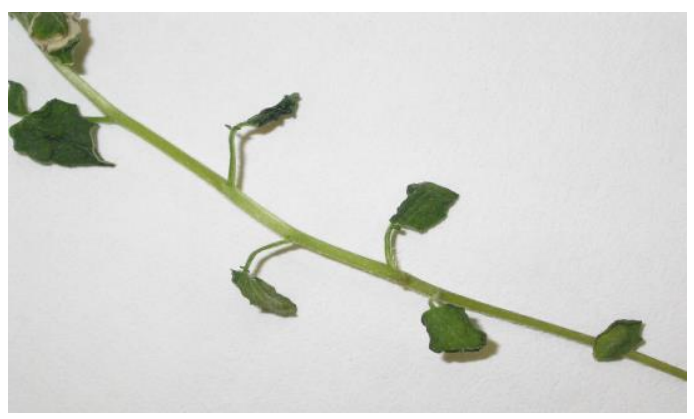

18. ábra. A 'Réka' $\left(F_{\mathrm{i}}=2,37\right)$, mint mérsékelten rezisztens fajta in vitro növényein jelentkezö tünetek

A mérsékelt fogékonysággal jellemezhető fajtáknál gyakori volt, hogy a szúrás helyéről kiindulva a szár rothadásnak indult és kettéhasadt, de ez csak néhány mm-re terjedt ki (19. ábra bal oldali képén nyíllal jelezve). Emellett a levelek hervadása volt megfigyelhető. A szúrás helye jól látható, és szártünetek is jelentkeztek (19 ábra jobb oldali képen nyíl jelzi).
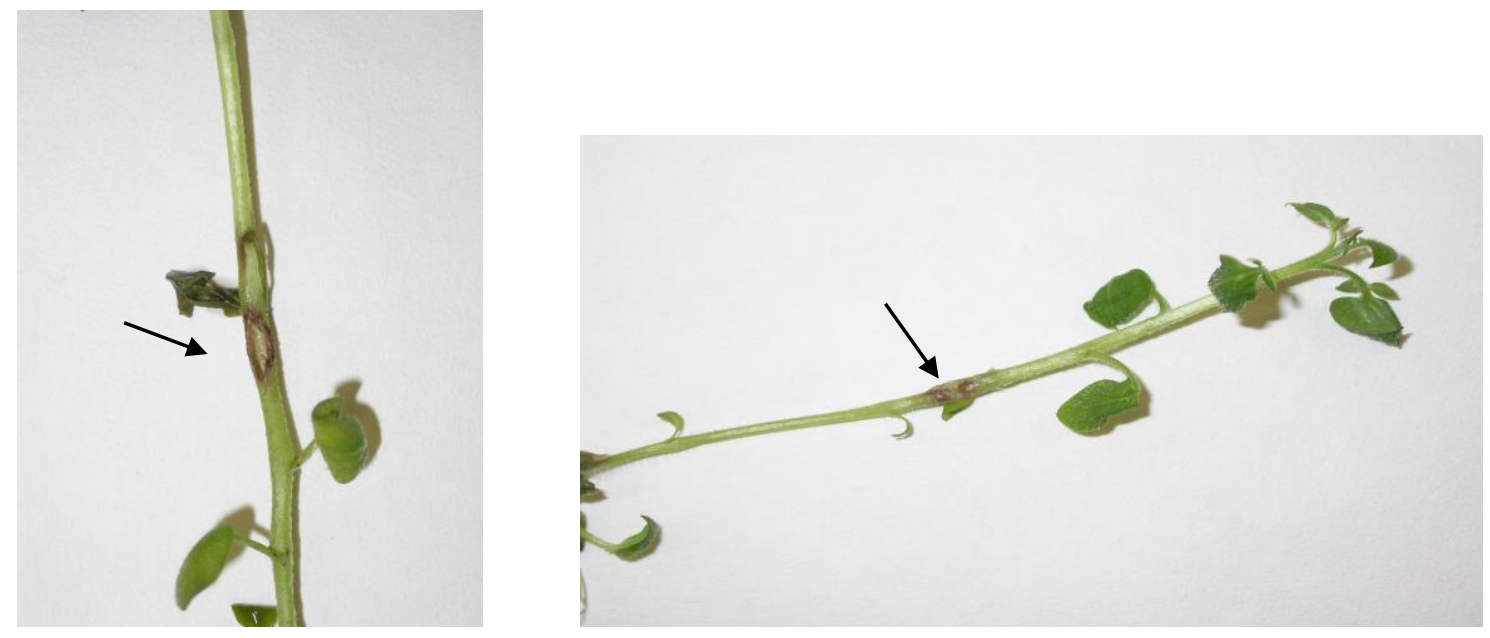

19. ábra. A 'Desiree' $\left(\mathrm{F}_{\mathrm{i}}=3,04\right)$, mint mérsékelten fogékony fajta in vitro növényein jelentkező tünetek

Az erősen fogékony kategóriába tartozó klónok jellegzetes szár- és levéltüneteket mutattak. A levelek hervadása már a fertőzést követő első napon megfigyelhető volt a növények egyharmadánál. A fertőzést követő hetedik napon a növény leveleinek $90 \%$-a elrothadt és súlyos szártünetek is mutatkoztak. A szár 90\%-a vagy egésze elrothadt. Előfordult, hogy a szúrás helyétől kezdődően a szár hosszában kettéhasadt (20. ábra képen nyíl jelzi). 

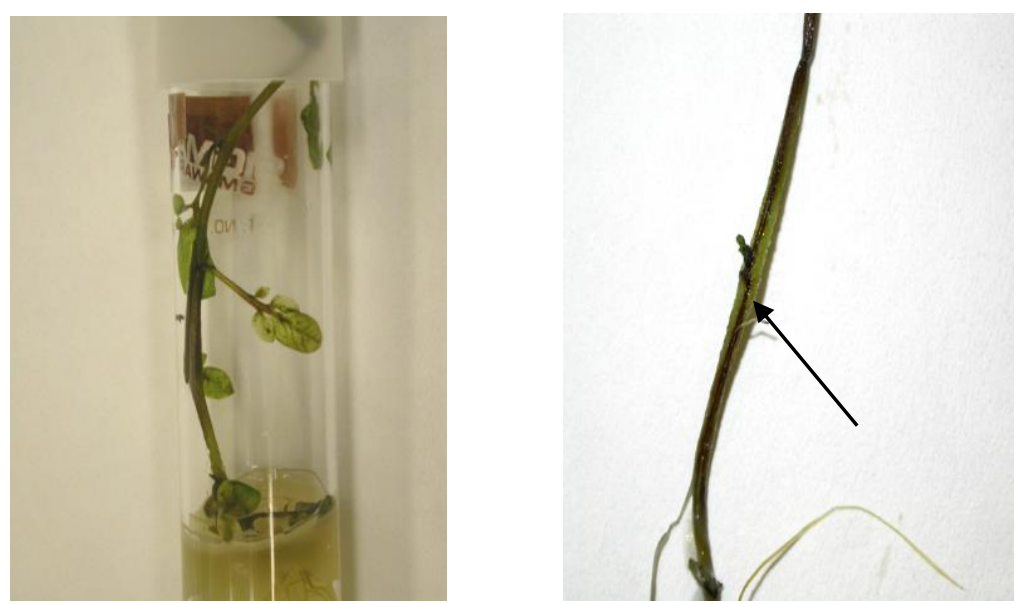

20. ábra. A 98/91 klón $\left(F_{i}=3,04\right)$, mint erösen fogékony klón in vitro növényein mutatkozó tünetek

\subsubsection{A Pectobacterium carotovorum subsp. carotovorum fertőzés hatása}

Az itt bemutatott eredmények a három vizsgálati év (2003-2005) átlagát reprezentálják. Eredményeinket figyelembe véve elmondhatjuk, hogy már a fertőzést követő első nap elteltével különbségeket tudtunk megállapítani a fajták között (21. ábra és 2. melléklet 2-3. táblázat). A kísérletek kiértékelése után legfogékonyabbnak ítélt 98/91 klón már a fertőzést követő első napon is a legfogékonyabbnak bizonyult, és a fajták között elfoglalt helye a későbbiekben sem változott. Ebben a megfigyelési időpontban négy csoportot különítettünk el. A megfigyelt genotípusok közül három (77365/103, 77399/514, 'Rachel') tünetmentesnek ( $\left.\mathrm{F}_{\mathrm{i}}=1,0\right)$ bizonyult. Szártüneteket még nem tapasztaltunk a megfigyelés ezen korai stádiumában. A fajták közötti különbségek a leveleken jelentkező hervadási tünetekből adódtak. A fertőzési index értéke 1-tól 1,64-ig terjedt.

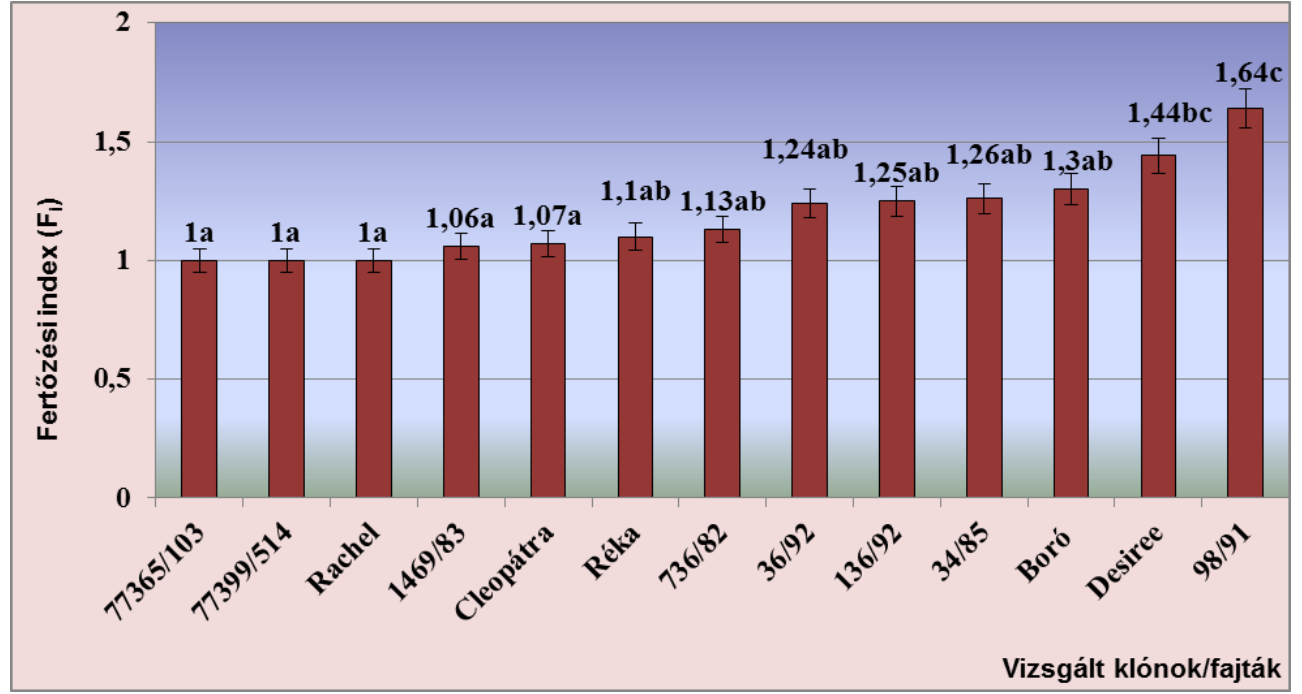

21. ábra. In vitro burgonyanövények hajtásainak átlagos fogékonysági értéke az Pectobacterium carotovorum subsp. carotovorum fertőzést követő első napon. A fajták szignifikánsan $(\mathrm{p}<0,05)$ különböző csoportokba sorolását eltérő betük jelölik 
Az inokulálást követő harmadik napon az átlagos értékek alapján a fajták jobb elkülönülését tapasztaltuk. Ekkor öt csoportot tudtunk elkülöníteni (22. ábra). Természetesen az átlagos fertőzési indexek értéke is magasabb lett, 1,06 és 2,83 között változott. A legkisebb fertőzöttség a 77399/514 klónhoz tartozó növényeken volt megfigyelhető, de a 'Rachel', 77365/103, 1469/83, 'Cleopátra', 'Réka', 34/85, 'Desiree' és a 736/82 genotípusokon tapasztalt tünetek súlyossága sem tért el szignifikánsan ettől. A legmagasabb értéket ekkor is a 98/91 klón esetében tapasztaltuk.

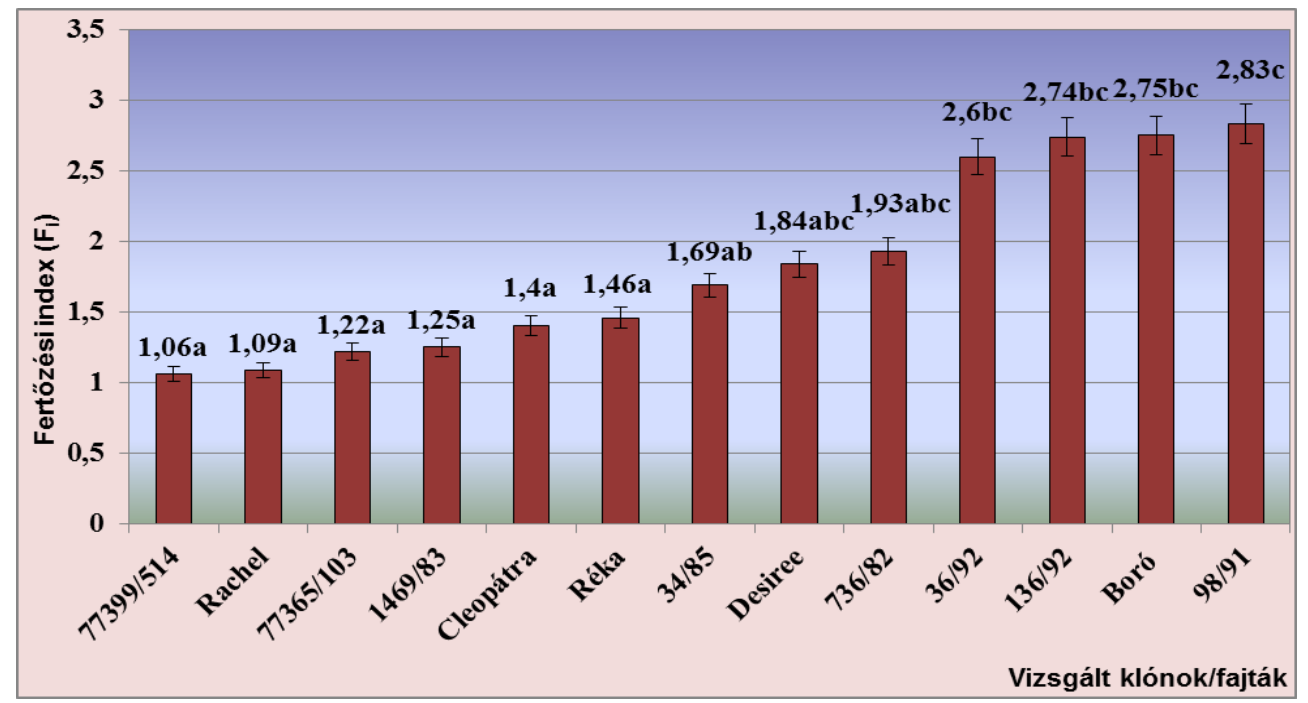

22. ábra. In vitro burgonyanövények hajtásainak átlagos fogékonysági értéke az Pectobacterium carotovorum subsp. carotovorum fertőzést követő harmadik napon. A fajták szignifikánsan $(\mathrm{p}<0,05)$ különböző csoportokba sorolását eltérő betük jelölik

A fertőzést követő hetedik nap volt az utolsó megfigyelési időpontunk. A fertőzési index 1,63 és 4,69 között mozgott. Továbbra is öt csoportot különítettünk el egymástól, hasonlóan a második megfigyelési időpontban (22. ábra) tapasztaltakhoz. Viszont a fajták csoportokon belüli elhelyezkedése módosult. Míg a második megfigyelési időpontban a legjobb eredményt elérő kategóriába hat klón tartozott, melyek szignifikánsan nem különböztek egymástól (22. ábra), addig a harmadik megfigyelési időpontban (fertőzést követő hetedik nap) már csak 5 klónt sorolhattunk ebbe a kategóriába (23. ábra). 


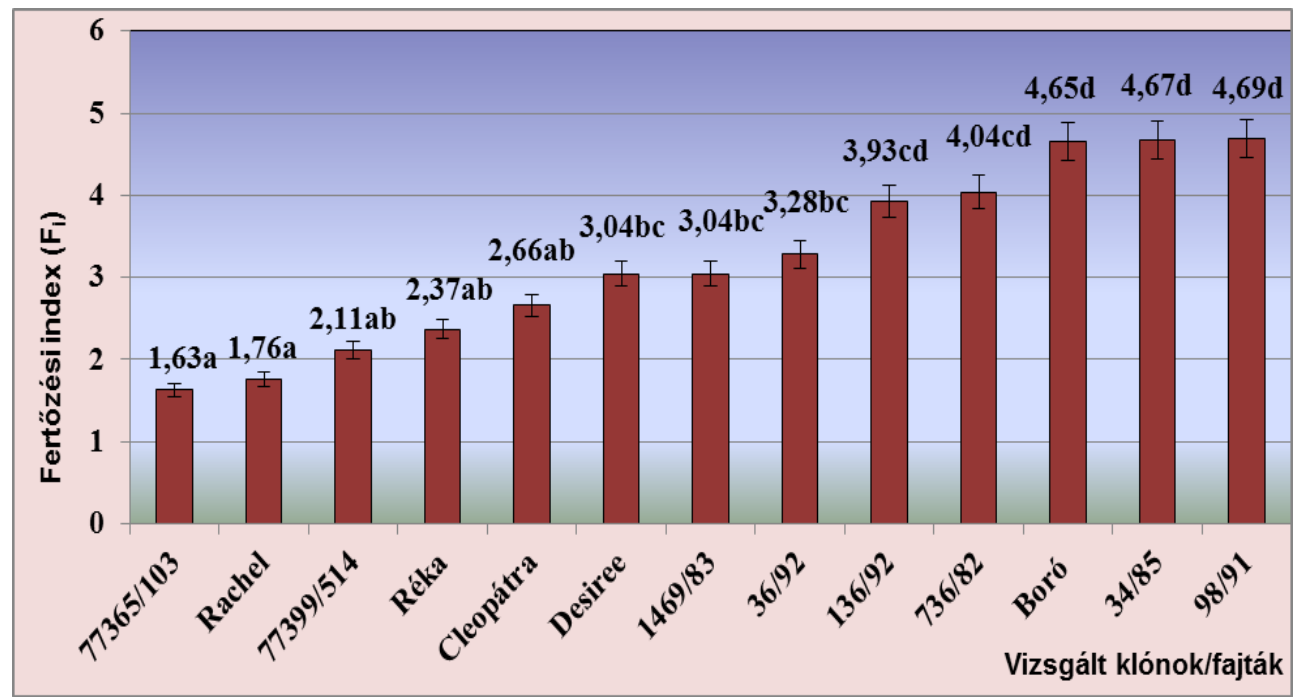

23. ábra. In vitro burgonyanövények hajtásainak átlagos fogékonysági értéke az Pectobacterium carotovorum subsp. carotovorum fertőzést követő hetedik napon. A fajták szignifikánsan $(p<0,05)$ különböző csoportokba sorolását eltérő betük jelölik

A klónok a fertőzöttségi kategóriák szerint a következőképpen csoportosíthatók:

rezisztens: 77365/103 és a 'Rachel'

mérsékelten rezisztens: 77399/514, a 'Réka' és a 'Cleopátra'

mérsékelten fogékony: 'Desiree', 1469/83 és a 36/92

fogékony: 136/92 és a 736/82

erősen fogékony: 'Boró', 34/85 és a 98/91

\subsubsection{A Dickeya dadantii fertőzés hatása}

Az Dd-val történő fertőzések az Pcc-hoz hasonlóan történtek. A kísérleteket 2004 és 2008 között végeztük. Eredményeink szintén három független kísérlet összevont eredményeit tükrözik.

Az első megfigyelési időpontban, a fertőzést követő első napon (24. ábra) nem tapasztaltunk szignifikáns különbséget a fajták között (2. melléklet 4-5. táblázat). Valamennyi fajtát azonos kategóriába soroltuk. A fertőzési indexek 1,0 és 1,18 között változtak. Hasonlóan a Pcc-val történő fertőzést követő állapothoz, itt is tünetmentesnek bizonyultak a következő klónok: 77365/103, 77399/514 és a 'Rachel', valamint ebben az esetben még ide kell sorolni az 1469/83 klónt. Az előző eredményekkel összevetve hasonlóság, hogy az itt legmagasabb fertőzési indexet produkáló 'Boró' az Pcc-val szemben is fogékonynak bizonyult, sőt a végső csoportosításnál az erősen fogékony kategóriába soroltuk. 


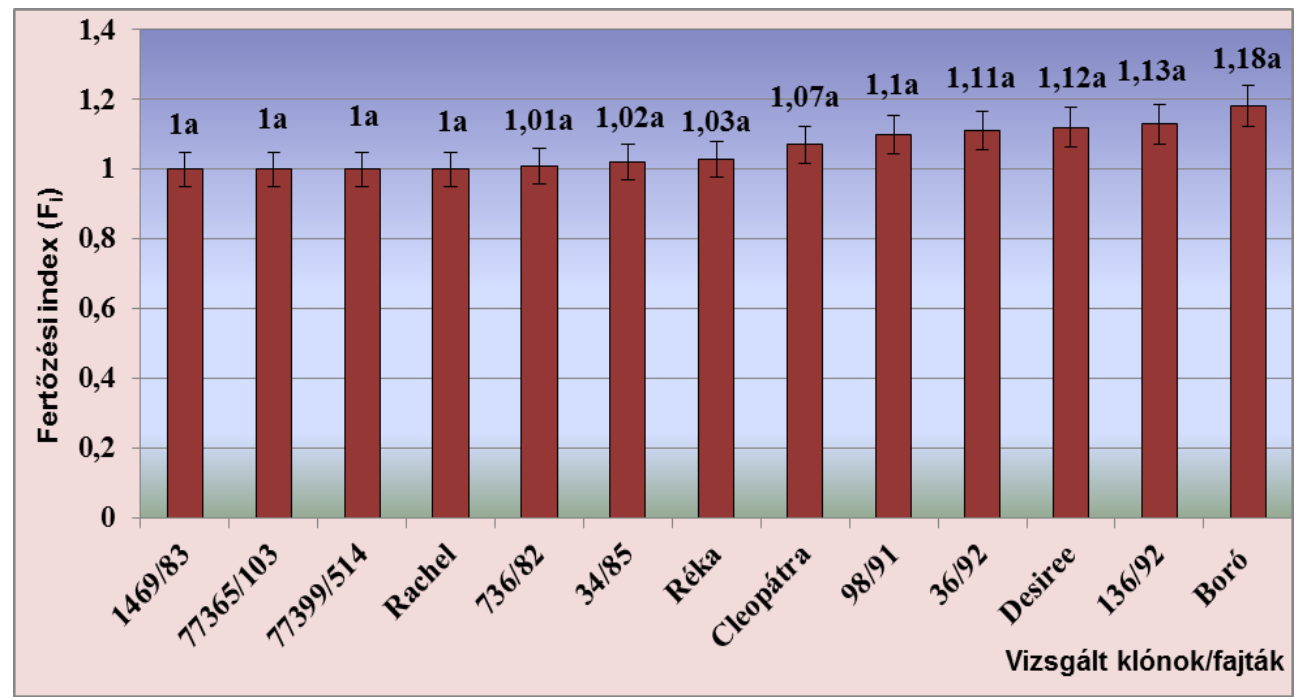

24. ábra. In vitro burgonyanövények hajtásainak átlagos fogékonysági értéke az Dickeya dadantii fertőzést követő első napon. A fajták szignifikánsan ( $\mathrm{p}<0,05)$ különböző csoportokba sorolását eltérő betük jelölik

A második megfigyelési időpontban módosult a fajták sorrendje (25. ábra). A legjelentősebb változás a 34/85 klón helyében következett be. A legkisebb fertőzési index volt jellemző, $\mathrm{F}_{\mathrm{i}}=$ 1,06, ami azért is érdekes, mert az $P c c$-val szemben erősen fogékonynak bizonyult.

A legfogékonyabb ebben a megfigyelési időpontban a 136/92 klón volt, $F_{i}=2,08$ értékkel. A fajták szignifikánsan elváltak egymástól, de ugyanaz a helyzet alakult ki, mint az Pcc-val szemben megfigyelteknél. Öt genotípus (34/85, 'Rachel', 1469/83, 77399/514 és a 77365/103) alkotja a szignifikánsan legjobb eredményt produkálók csoportját, de ezek közül csak egy marad meg a harmadik megfigyelési időpontra, mely a legjobb eredményt érte el (2. melléklet 5. táblázat).

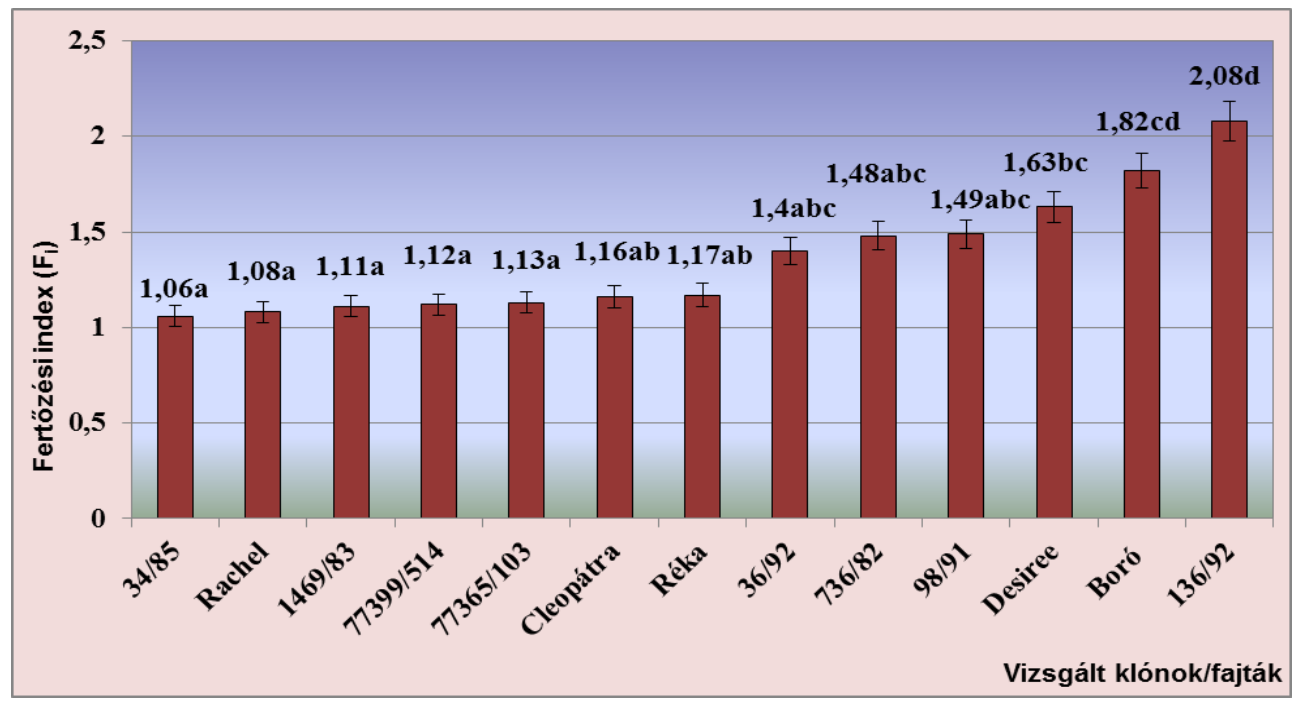

25. ábra. In vitro burgonyanövények hajtásainak átlagos fogékonysági értéke az Dickeya dadantii fertőzést követő harmadik napon. A fajták szignifikánsan $(\mathrm{p}<0,05)$ különböző csoportokba sorolását eltérö betük jelölik 
A harmadik megfigyelési időpontban (26. ábra) az $D d$-val szemben legellenállóbb a 34/85 volt, mely egyedül alkotja a rezisztensek csoportját. A legfogékonyabbak a baktériummal szemben a 'Boró' és a 136/92. A fertőzési indexek az Pcc-hoz viszonyítva szükebb tartományban mozogtak, 1,16 és 2,35 között változtak. Négy csoportba soroltuk a vizsgált genotípusokat, melyek közül a legtöbb a közepes kategóriákat képviseli, mérsékelten rezisztens és mérsékelten fogékony.

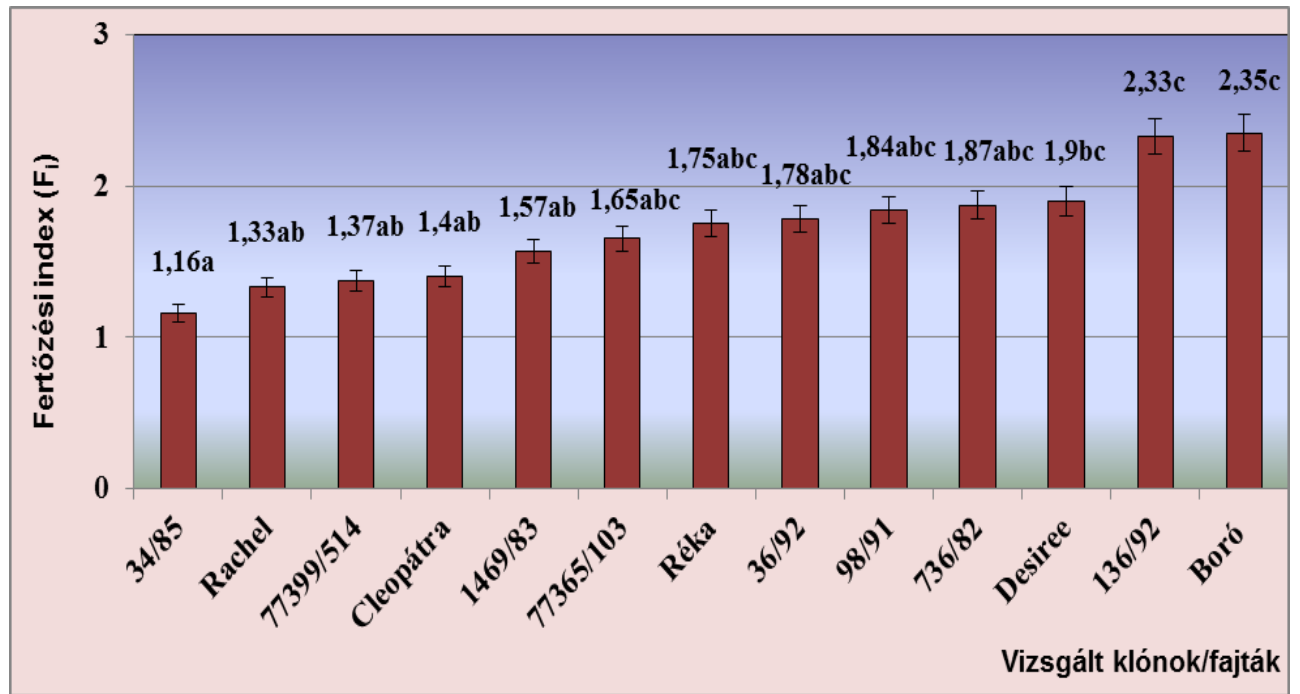

26. ábra. In vitro burgonyanövények hajtásainak átlagos fogékonysági értéke az Dickeya dadantii fertőzést követő hetedik napon. A fajták szignifikánsan $(\mathrm{p}<0,05)$ különböző csoportokba sorolását eltérő betűk jelölik

A klónok fertőzöttségi csoportosítása kategóriák szerint:

rezisztens: 34/85

mérsékelten rezisztens: 1469/83, 77399/514, 'Cleopátra', 'Rachel'

mérsékelten fogékony: 77365/103, 36/92, 98/91, 736/82, 'Desiree’ és a 'Réka'

erősen fogékony: 136/92 és a 'Boró'

Összehasonlítva a mikroszaporított burgonyanövények $P c c$ és $D d$-val történő fertőzési kísérleteinek eredményeit, megállapíthatjuk, hogy az $P c c$ erösebb tüneteket okozott az in vitro burgonyahajtásokon, mint az $D d$. A fertőzési indexek $P c c$ esetén 1 és 4,69 között változtak a megfigyelési időpontokban. Ezzel szemben az $D d$ esetén jóval szükebb tartományba (1-től 2,35ig) estek ezek az értékek.

\subsubsection{Baktérium sejtszám meghatározása}

A $P c c$-val történő fertőzést követően a baktérium sejtszám meghatározását a fertőzött növényi szövetekből visszaizolálások alapján végeztük. A fajták közötti különbségeket az összes hígítás átlagában a visszaizolálás helye szerint szeretném bemutatni. Két időpontban történt a 
visszaizolálás: a fertőzést követő harmadik és hetedik napon a megfigyelési időpontokkal párhuzamosan.

A fertőzést követő harmadik napon történő visszaizolálás eredményét a 27 . ábra és a 2 . melléklet 6-7. táblázat mutatja be. Valamennyi vizsgált genotípusnál a szúrás környéki részböl (SZ) sikerült a legtöbb baktériumot kitenyészteni. A fajták közötti eltéréseket tekintve elmondható, hogy mindhárom mintavételi helyen kiugróan magas baktérium sejtszámot kaptunk a 98/91 esetében, ami összhangban volt a hajtásfertőződés eredményeivel.

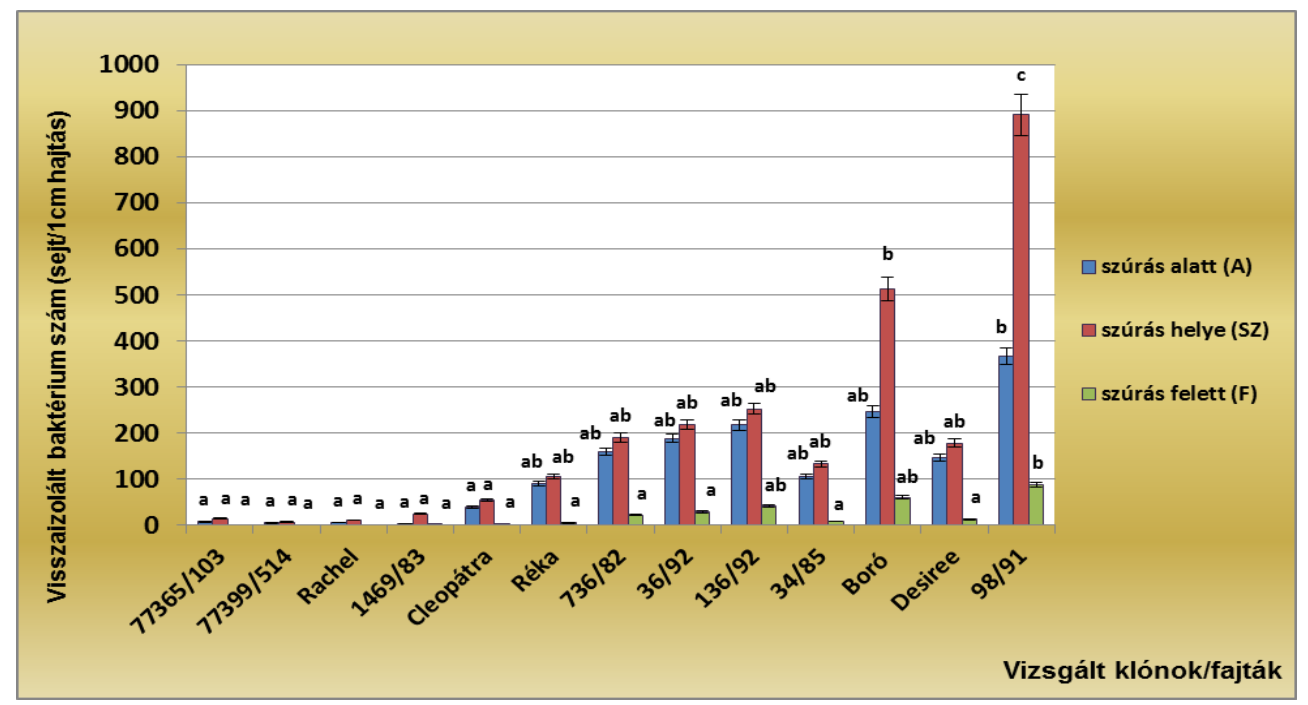

27. ábra. Pectobacterium carotovorum subsp. carotovorum fertőzést követő harmadik napon mért baktérium sejtszám eredmények in vitro burgonya hajtásokon

A fertőzést követő hetedik napon történő visszaizoláláskor kapott eredményeket a 28. ábra és a 2. melléklet 8-9. táblázat foglalja össze. Jól látható, hogy a baktérium sejtszám a szúrás alatti mintavételi helyeken a legmagasabb egyetlen vizsgált klón kivételével. Mindebből arra következtethetünk, hogy a fertőzés a szárban lefelé terjed. A 98/91 itt is szignifikánsan eltért a többi fajtától. Ebben az esetben nem annyira egyértelmü a terjedés iránya, mindhárom mintavételi helyről magas baktérium sejtszámot tenyésztettünk ki, ami a fajta nagyfokú fogékonyságával magyarázható. 


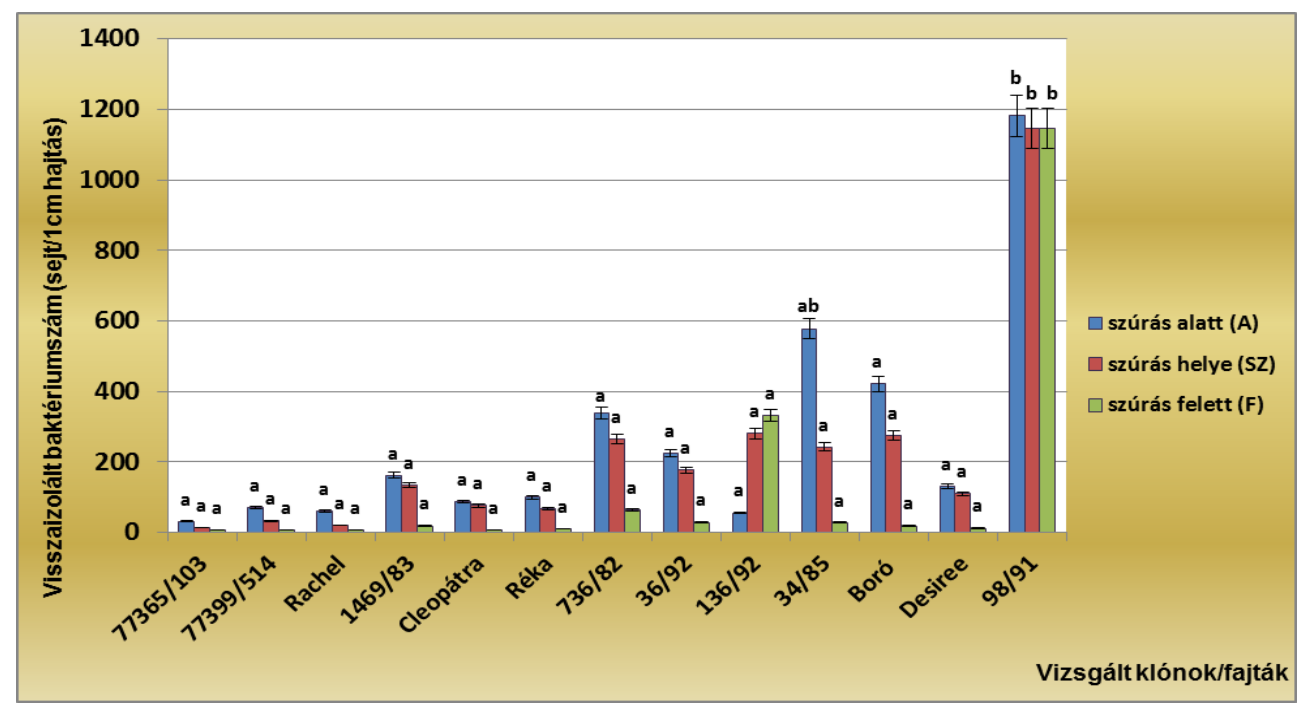

28. ábra. Pectobacterium carotovorum subsp. carotovorum fertőzést követő hetedik napon mért baktérium sejtszám eredmények in vitro burgonya hajtásokon

A $D d$-val történő fertőzést követő harmadik napon kapott eredményekből hasonló következtetést tudtunk levonni, mint az $P c c$-val végzett kísérleteknél (29. ábra és a $\underline{2 . ~ m e l l e ́ k l e t ~}$ 10-11. táblázat). A fertőzést követő harmadik nap a szúrás környéki mintákból izoláltuk vissza a legtöbb baktériumot. A fajták közötti eltérések párhuzamba állíthatók a hajtásfertőzéskor kapott eredményekkel. A 'Boró' és a 136/92 genotípusból vett mintákból izoláltuk vissza a legtöbb baktériumot, míg a legkevesebbet a 34/85 klónból.

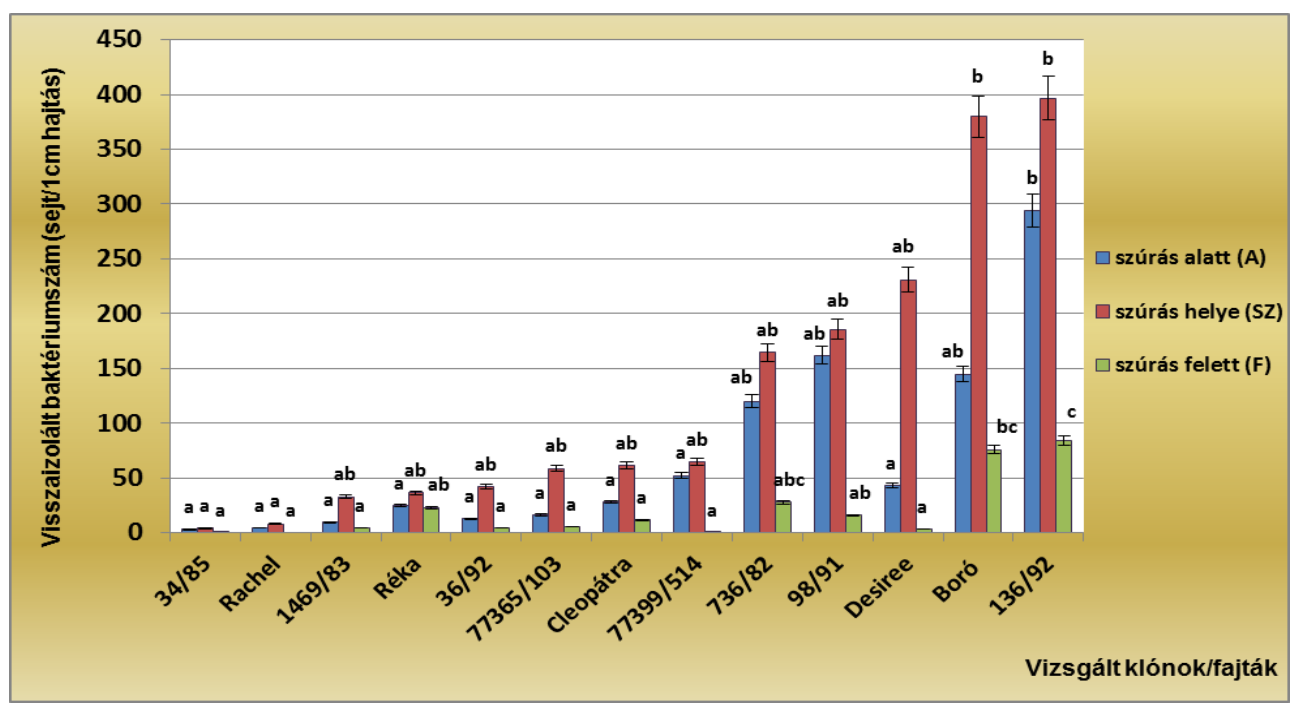

29. ábra. Dickeya dadantii fertőzést követő harmadik napon mért baktérium sejtszám eredmények in vitro burgonya hajtásokon

A fertőzést követő hetedik napos visszaizolálásnál szintén a szúrás helyéről vett mintákból sikerült a legtöbb baktériumot visszaizolálni, akárcsak a harmadik napon (30. ábra és a 2 . melléklet 12-13. táblázat). Ezzel párhuzamosan a szúrás alatti mintákban is jelentősen megnőtt a baktérium sejtszám, ami alátámasztja azt a feltételezésünket, hogy elsősorban lefelé terjed a 
fertőzés a szárban. Úgy tünik, hogy az $D d$ lassabban szaporodik és terjed a hajtásban, mint az $P c c$. Ez alátámasztja azt is, hogy miért nem okozott az $D d$ olyan súlyos tüneteket az in vitro burgonyahajtásokon, mint a $P c c$.

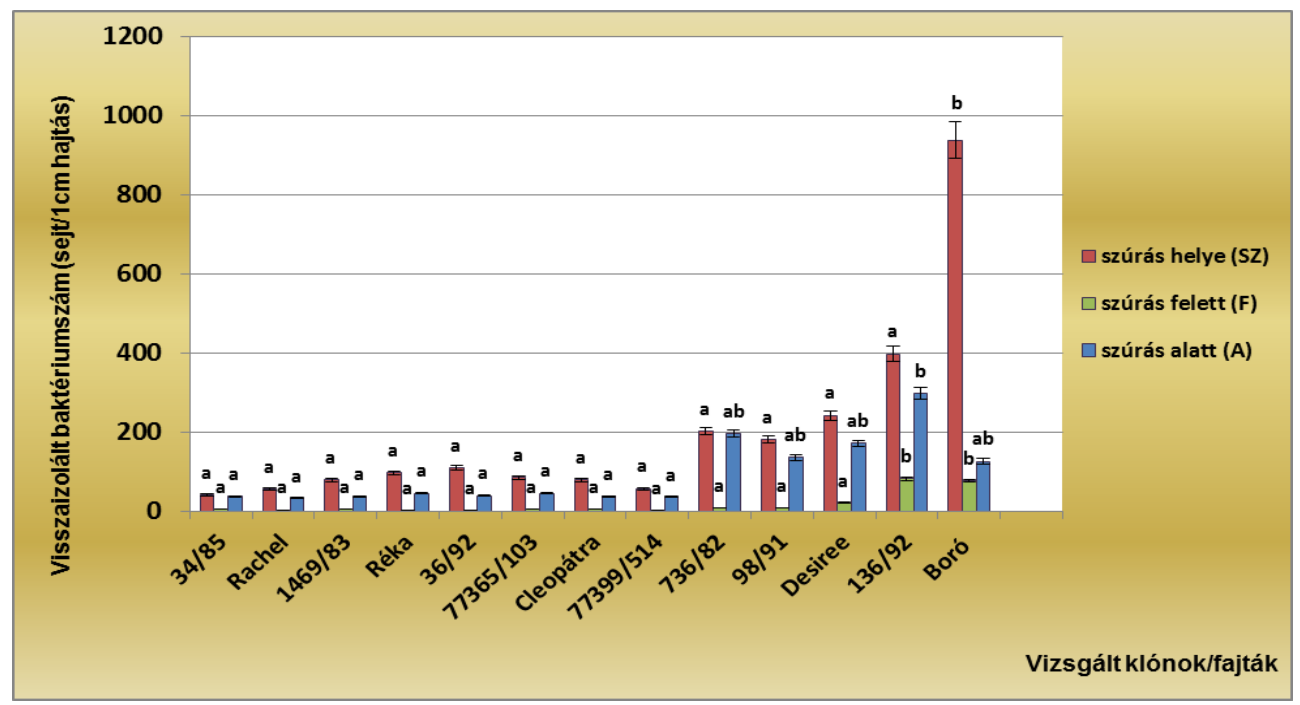

30. ábra. Dickeya dadantii fertőzést követő hetedik napon mért baktérium sejtszám eredmények in vitro burgonya hajtásokon

5.2.2. Burgonya mikrogumók fogékonysága a gumófertőzés alapján

Az in vitro növény mellett az in vitro gumó a burgonya mikroszaporítás másik terméke. Ezért kidolgoztunk egy mikrogumó fertőzési technikát is, mellyel leteszteltük az előzőekben vizsgált burgonyafajtákat és klónokat. Az in vitro gumófertőzési kísérleteket 2004 és 2008 között végeztük.

\subsubsection{A Pectobacterium carotovorum subsp. carotovorum fertőzés hatása}

Már az első megfigyelési időpontban (fertőzést követő első nap) szignifikáns különbségeket tapasztaltunk a fajták között (31. ábra és a 2. melléklet 14-15. táblázat). Legkevésbé fogékony a 98/91, 34/85 és a 'Rachel' volt. A 'Rachel' az in vitro hajtásfertőzés ugyanezen megfigyelési időpontjában szintén hasonló eredményt adott. Eltérés mutatkozik viszont a 98/91 klónnál, ami az in vitro hajtásfertőzéskor következetesen valamennyi megfigyelési időpontban a legfogékonyabbnak bizonyult. A 34/85 pedig szintén a fogékonyabb kategóriákat képviselte az in vitro hajtásfertőzéskor. Jelen megfigyelési időpontban még kevésbé válnak el az egyes fajták egymástól. Ezt mutatja az is, hogy statisztikailag egy csoportba tartozó „legfogékonyabbakat” hét genotípus képviseli az első megfigyelési időpontban. 


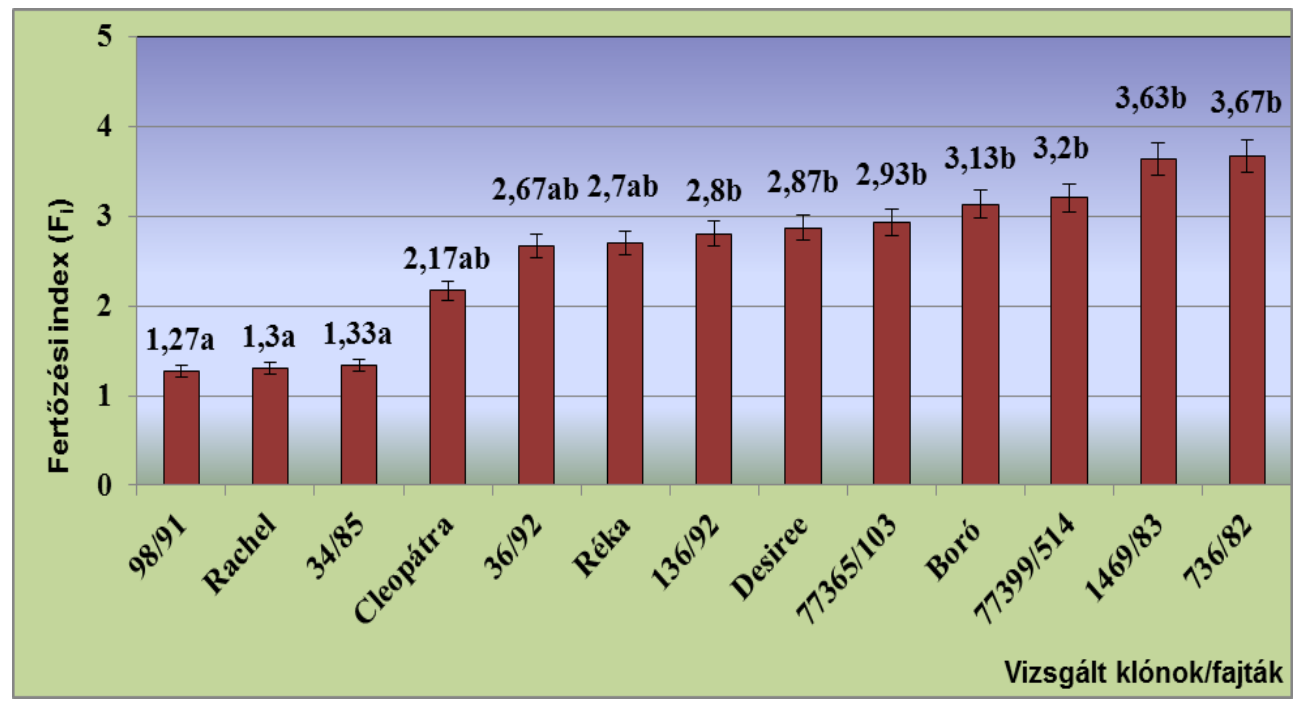

31. ábra. In vitro burgonya gumók átlagos fogékonysági értéke az Pectobacterium carotovorum subsp. carotovorum fertőzést követő első napon. A fajták szignifikánsan $(p<0,05)$ különböző csoportokba sorolását eltérő betűk jelölik

A második megfigyelési időpontban kapott eredményeket a 32. ábra mutatja be. Ebben az időpontban váltak el egymástól legjobban a fajták. Továbbra is a 98/91 a legellenállóbb. Ami hasonlóság az in vitro hajtásfertőzés ugyanezen időpontjában tapasztaltakkal, hogy a 'Rachel' mindkét esetben ellenállóbbnak bizonyult, valamint a 136/92 mindkét esetben fogékony volt.

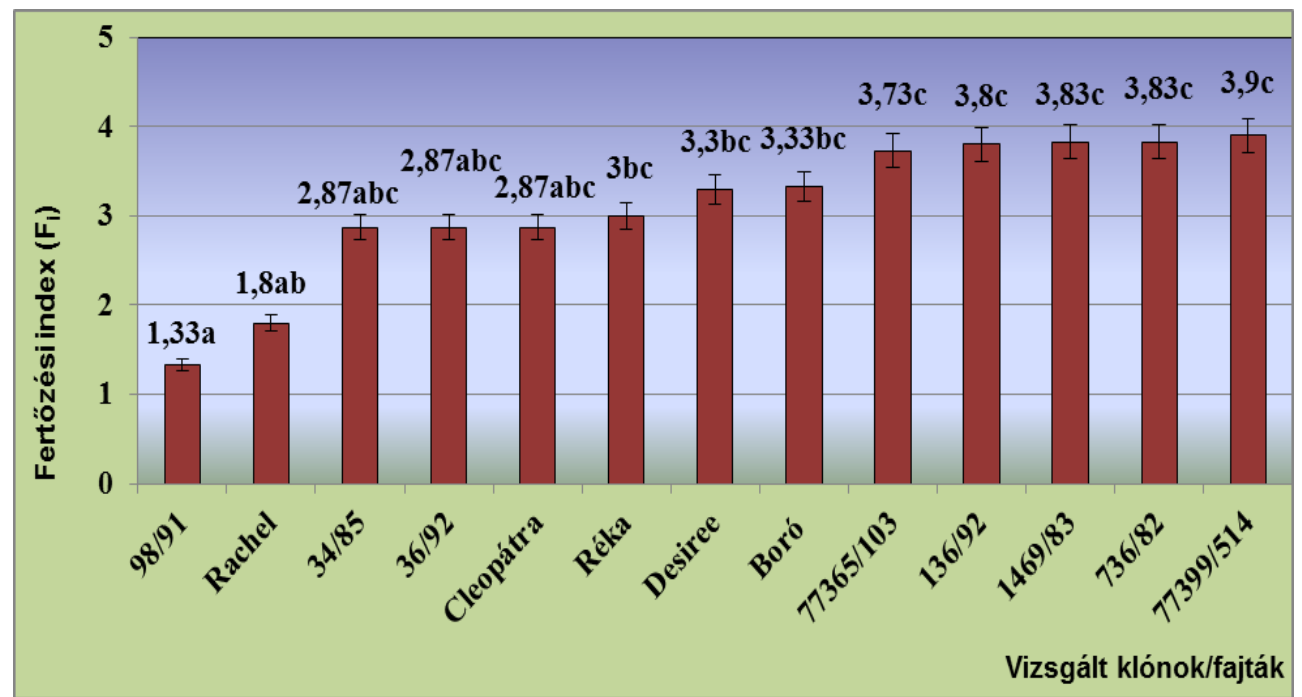

32. ábra. In vitro burgonya gumók átlagos fogékonysági értéke az Pectobacterium carotovorum subsp. carotovorum fertőzést követő harmadik napon. A fajták szignifikánsan $(p<0,05)$ különböző csoportokba sorolását eltérő betűk jelölik

Az utolsó megfigyelési időpontban (fertőzést követő hetedik nap) csak a 'Rachel' és a 98/91 válik el egymástól szignifikánsan (33. ábra). A 'Rachel' a teljes vizsgálat alatt ellenállónak bizonyult az Pcc-val szemben. A 98/91 viszont „meglepő” eredményt hozott, a fertőzést követő egy hét után a gumók több, mint 75\%-a elrothadt. Ez azért is érdekes, mert a fertőzést követő 
első két megfigyelési időpontban kapott eredmények alapján feltételezhetnénk, hogy egy ellenállóbb klónról van szó, ahol a gumó nem azonos módon reagál a fertőzésre, mint az in vitro hajtás. A kapott végeredmény összhangban van az in vitro hajtásfertőzés eredményével. Eltérésként említhető meg a korábbiakhoz képest, hogy az 77399/514 az első két megfigyeléskor határozottan fogékonynak bizonyult, a kísérlet végeredményében pedig egy közepes fogékonyságot tapasztaltunk.

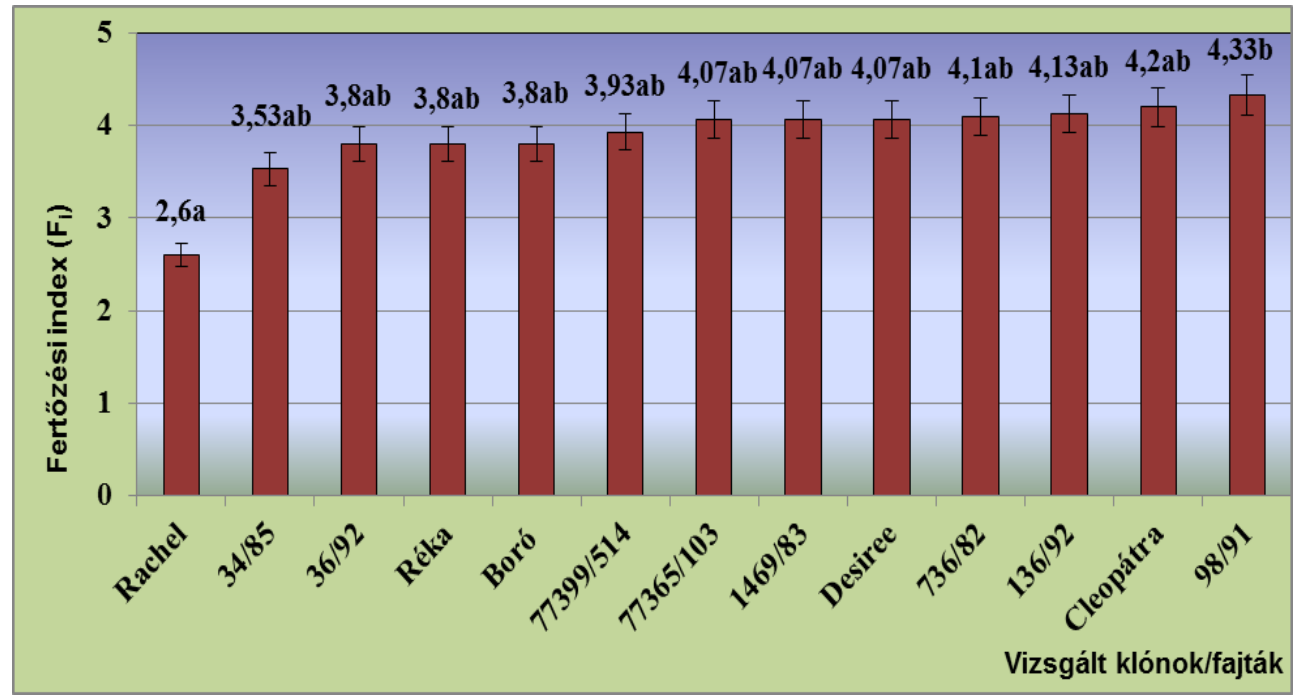

33. ábra. In vitro burgonya gumók átlagos fogékonysági értéke az Pectobacterium carotovorum subsp. carotovorum fertőzést követő hetedik napon. A fajták szignifikánsan $(\mathrm{p}<0,05)$ különböző csoportokba sorolását eltérő betük jelölik

A klónok fertőzöttségi csoportosítása kategóriák szerint:

rezisztens: 'Rachel'

mérsékelten fogékony: 34/85, 1469/83, 36/92, 77399/514, 136/92, 736/82, 77365/103, 'Réka', 'Cleopátra', 'Desiree' és a 'Boró'

erősen fogékony: 98/91

\subsubsection{A Dickeya dadantii fertőzés hatása}

Az első megfigyelési időpontban a 77399/514 szignifikánsan ellenállóbbnak bizonyult a 'Rachel', 'Boró' és 'Cleopátra' fajtákhoz képest (34. ábra és a 2. melléklet 16-17. táblázat). A Pcc-val szemben rezisztensnek ítélt 'Rachel' ebben az esetben fogékonynak bizonyult. Ezzel szemben a 'Cleopátra', mely itt a legfogékonyabb volt, a Pcc-val szemben ellenállóbbnak találtuk ugyanezen megfigyelési időpontban. 


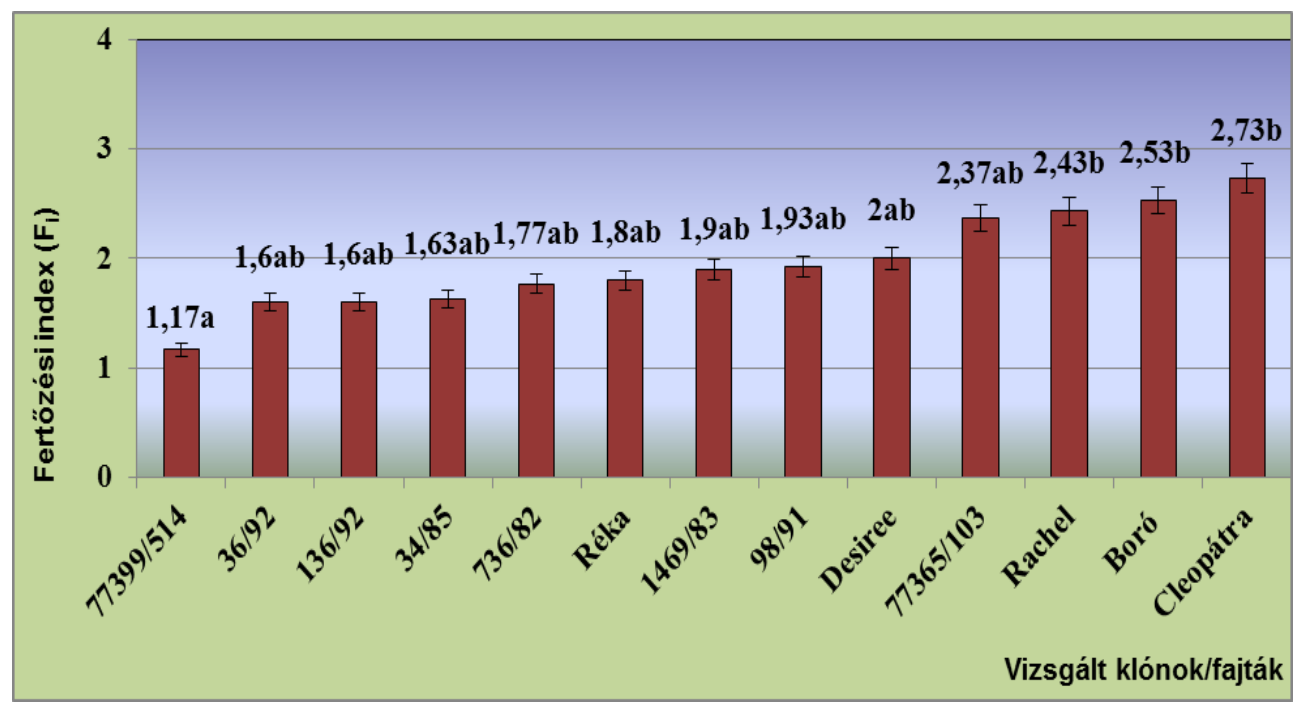

34. ábra. In vitro burgonya gumók átlagos fogékonysági értéke az Dickeya dadantii fertőzést követő első napon. A fajták szignifikánsan $(\mathrm{p}<0,05)$ különböző csoportokba sorolását eltérő betűk jelölik

A második megfigyelési időpontban kapott eredményeket a 35. ábrán mutatom be. Az előzőhöz hasonlóan itt is a 77399/514 szignifikánsan ellenállóbb, mint a 'Boró' és a 'Cleopátra'. Az Pcc-val történő fertőzések ugyanezen megfigyelési időpontjában legfogékonyabb 77399/514 az $D d$-val szemben viszont a legellenállóbb volt. Az $D d$-val végzett hajtásfertőzésekhez hasonlítva elmondható, hogy a 'Rachel' hajtásai ellenállóak voltak a baktériummal szemben, viszont a gumói már kevésbé, mérsékelt fogékonysággal jellemezhető. Az 77399/514 és 34/85 mindkét fertőzési módszer szerint ellenálló volt ugyanazon megfigyelési időpontban. A 136/82 esetében szintén nem egyformán reagált a hajtás és a gumó. Míg a hajtás a legfogékonyabb volt, addig a gumó mérsékelt fogékonysággal bírt. A ‘Cleopátra' ugyancsak nem egyformán reagált a fertőzésre, gumója fogékonyabb volt az $D d$-ra, a hajtása viszont mérsékelten fogékony.

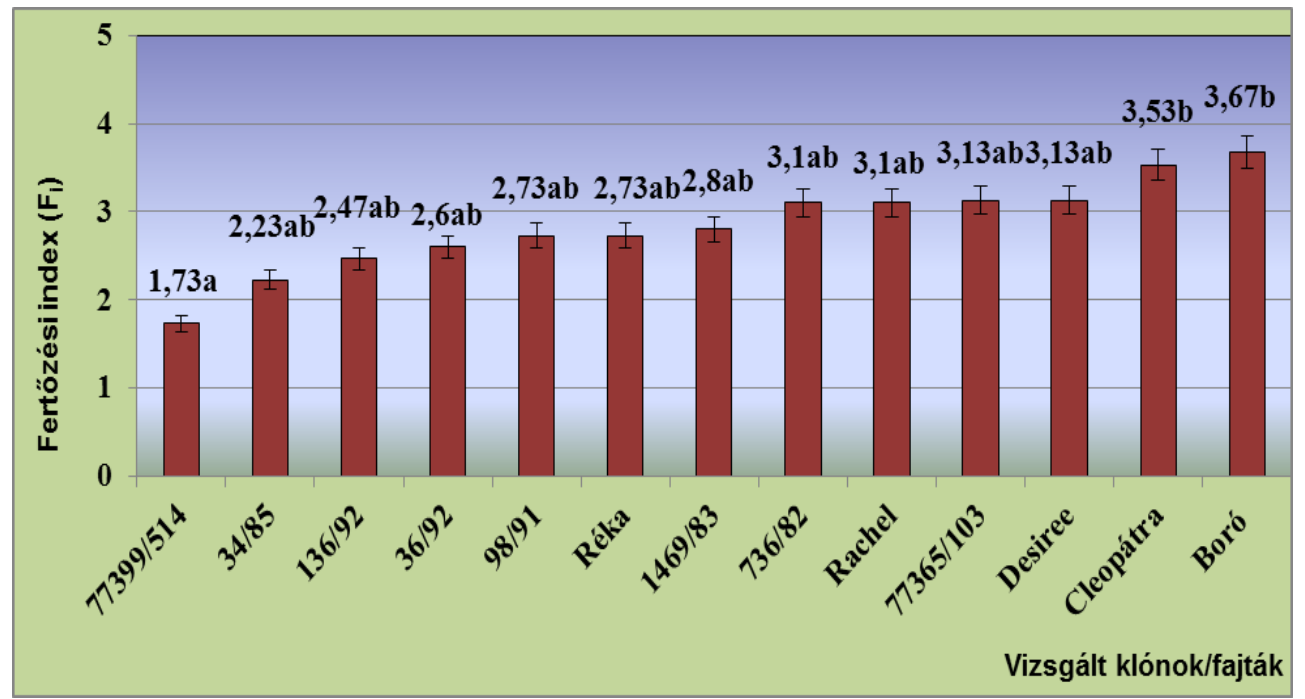

35. ábra. In vitro burgonya gumók átlagos fogékonysági értéke az Dickeya dadantii fertőzést követő harmadik napon. A fajták szignifikánsan $(\mathrm{p}<0,05)$ különböző csoportokba sorolását eltérő betük jelölik 
Az utolsó megfigyelési napon az előző időponthoz képest a fajták sorrendjében drasztikus változások nem történtek (36. ábra). A 77399/514 továbbra is szignifikánsan ellenállóbb, de már csak a 'Boró' fajtától. Az Pcc-val összehasonlítva az ott ellenállóbbnak mutatkozó 'Rachel' az $D d$-val szemben mérsékelten fogékony volt, míg a 98/91 erős fogékonyságot mutatott az $P c c$-val szemben, itt viszont szintén a közepes fogékonyságúak csoportjába soroltuk. Az $D d$-val szemben rezisztens 77399/514 és a legfogékonyabb 'Boró’ az $P c c$-val szemben mérsékelt fogékonysággal bírt.

Az in vitro hajtásfertőzéssel összehasonlítva elmondható, hogy a 'Boró' gumója és hajtása is erösen fogékonynak bizonyult az $D d$-val szemben. A 136/92 gumója mérsékelten rezisztens, míg a hajtása erősen fogékony volt. A 'Cleopátra' gumója mérsékelten fogékony, míg a hajtás fogékonyságát mérsékelten rezisztensnek ítéltük. A 'Desiree', a 98/91 és a 77365/103 hajtása és gumója is hasonlóan reagált a fertőzésre, mindkét esetben mérsékelten fogékonyak voltak.

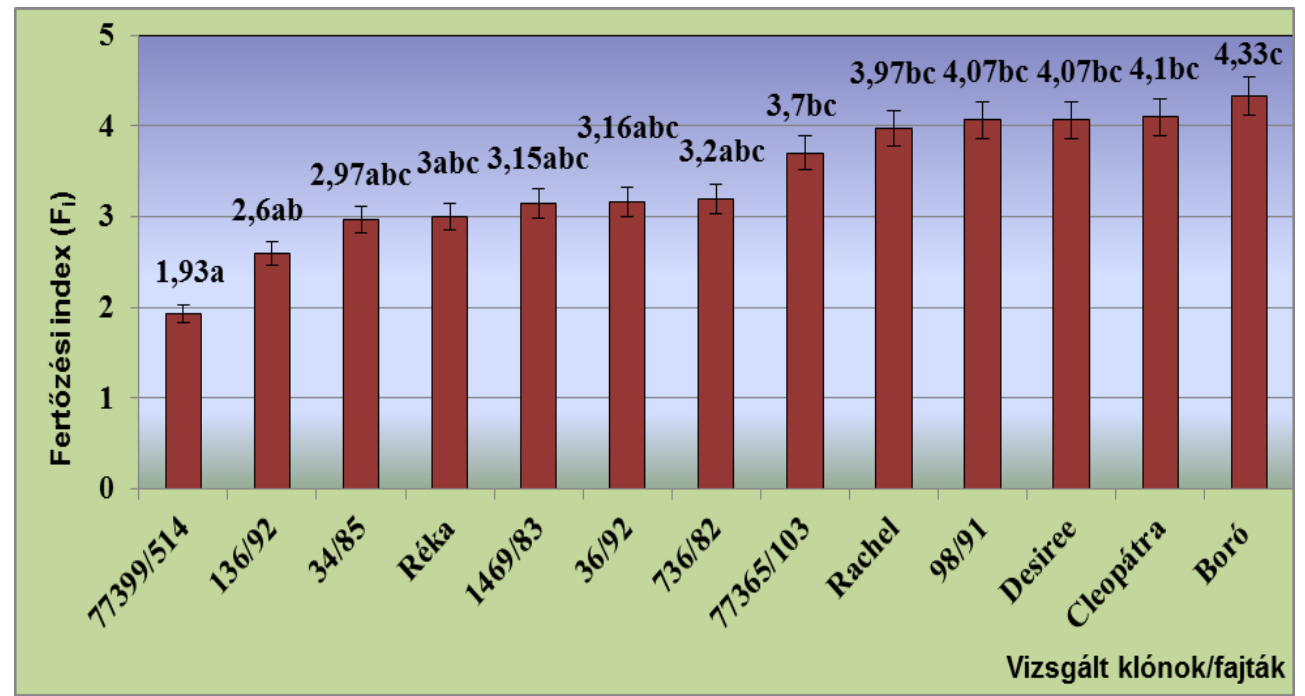

36. ábra. In vitro burgonya gumók átlagos fogékonysági értéke az Dickeya dadantii fertőzést követő hetedik napon. A fajták szignifikánsan $(\mathrm{p}<0,05)$ különböző csoportokba sorolását eltérő betűk jelölik

A klónok fertőzöttségi csoportosítása kategóriák szerint:

rezisztens: $77399 / 514$

mérsékelten rezisztens: 136/92, 34/85, 1469/83, 36/92, 736/82, 'Réka'

mérsékelten fogékony: 77365/103, 98/91, 'Cleopátra', 'Desiree' és a 'Rachel'

erösen fogékony: 'Boró'

A kontroll kezelésben (2. melléklet 17. táblázat), amikor is steril desztillált vízbe mártott tủvel szúrtuk meg a gumókat, a fajták között statisztikai különbségeket nem találtunk. A második megfigyelési időpontban kapott eredményeket mutatja be a 37. ábra. Szignifikáns különbségeket ugyan nem kaptunk, de a fajták nem egyformán reagáltak az öket ért mechanikai sérülésre. A 
legfogékonyabb a 'Rachel' volt, „fertőzési indexe” 1.73 lett. Ez azt jelenti, hogy a gumók közel 20\%-a elrothadt a szúrás után három nappal. A legellenállóbb a 1469/83, ami gyakorlatilag tünetmentes volt.

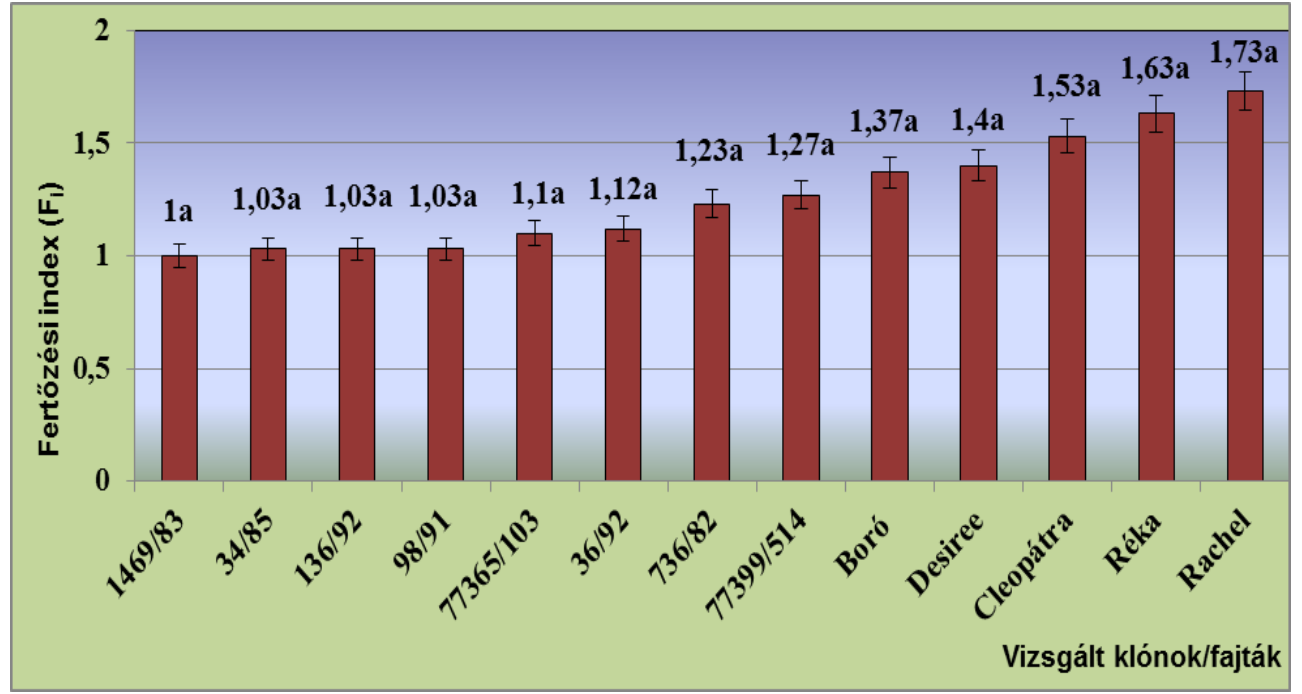

37. ábra. In vitro burgonya gumók átlagos fogékonysági értéke a kontroll kezelésben a második megfigyelési időpontban (fertőzést követő harmadik napon). A fajták szignifikánsan $(\mathrm{p}<0,05)$ különböző csoportokba sorolását eltérő betük jelölik

5.2.3. Primer burgonyagumók fogékonysága a gumófertőzés alapján

Az üvegházi gumófertőzéseket 2006 és 2008 között végeztük. Egy-egy kísérlet alkalmával 20-20 korongot fertőztünk genotípusonként és 5 db korongot használtunk a kontroll kezelésekben. A kísérletek eredményeit a három év átlagában értékeltük ki.

\subsubsection{A Pectobacterium carotovorum subsp. carotovorum fertőzés hatása}

Az üvegházi gumók fertőzésének módszerével vizsgálva a fajtákat megállapíthatjuk, hogy a legellenállóbb a 77399/514 volt a 37,86\%-os egészséges szövettömeg arányával. A legfogékonyabbnak a 'Réka' mutatkozott, az egészséges szövetaránya 3,87\% volt. Ezzel a módszerrel rezisztensnek ítélt 'Boró' és 'Cleopátra', valamint a 136/92 az in vitro gumófertőzéskor közepes fogékonyságot mutattak. A 36/92 és az 1469/83 mindkét gumófertőzés során fogékonynak bizonyultak (38. ábra és 2 . melléklet 18-19. táblázat). 


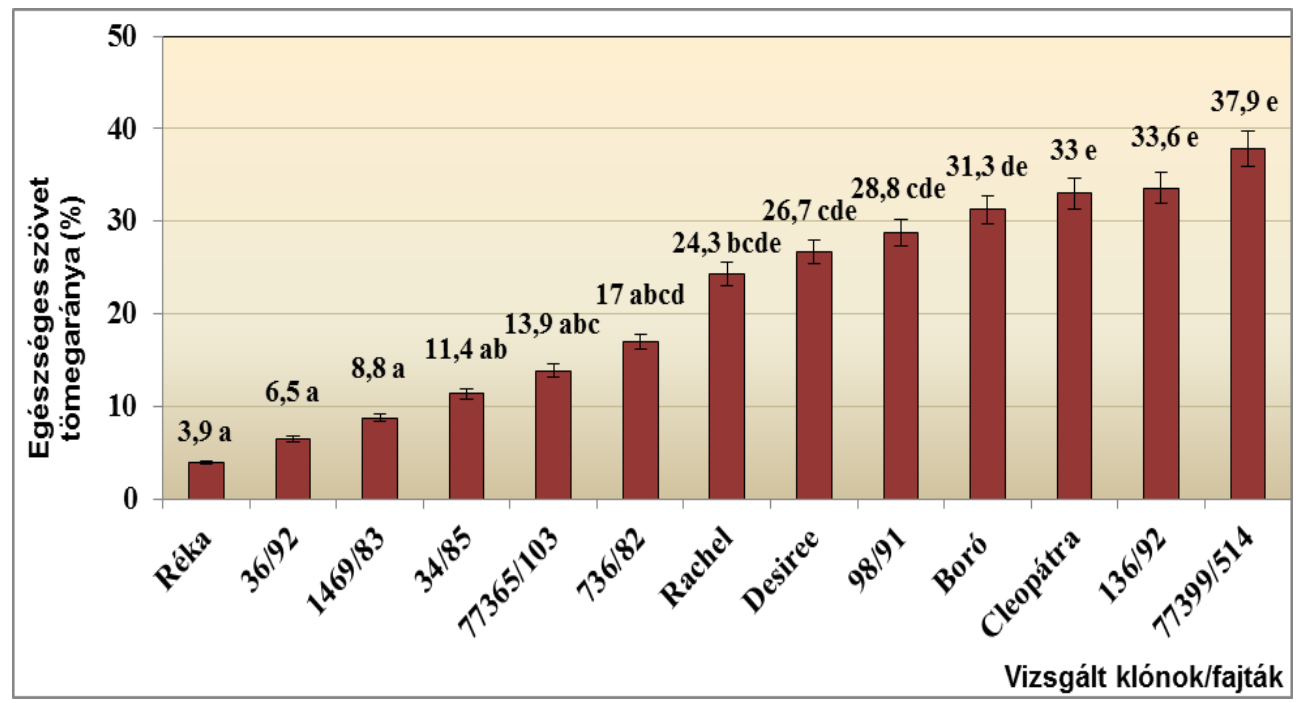

38. ábra. Üvegházi burgonyagumók átlagos fogékonysági értéke az Pectobacterium carotovorum subsp. carotovorumval történő fertőzési kísérletének eredményei alapján. A fajták szignifikánsan $(p<0,05)$ különbözö csoportokba sorolását eltérő betűk jelölik

A klónok fertőzöttségi csoportosítása kategóriák szerint:

rezisztens: 136/92, 77399/514, 'Boró', és a 'Cleopátra'

mérsékelten rezisztens: 98/91, 'Desiree' és a 'Rachel'

mérsékelten fogékony: 34/85, 77365/103 és a 736/82

fogékony: 36/92 és a 1469/83

erősen fogékony: 'Réka'

\subsubsection{A Dickeya dadantii fertőzés hatása}

A fertőzési eredményeket a 39. ábra és a 2. melléklet 20-21. táblázata foglalja össze. A legfogékonyabb a 'Cleopátra' volt, mely szignifikánsan is elvált a többi fajtától. Hasonló eredményt mutatott az in vitro gumófertőzéskor is. A 136/92 mindkét gumófertőzéskor ellenállóbbnak bizonyult. Ebben az esetben rezisztens 'Boró' és 'Desiree' mind az in vitro gumófertőzéskor, mind az in vitro hajtásfertőzéskor fogékonynak bizonyultak. Az 1469/83 klónt mind az in vitro gumófertőzéskor, mind az in vitro hajtásfertőzéskor mérsékelten rezisztens csoportba soroltuk, jelen esetben viszont fogékonynak bizonyult. 


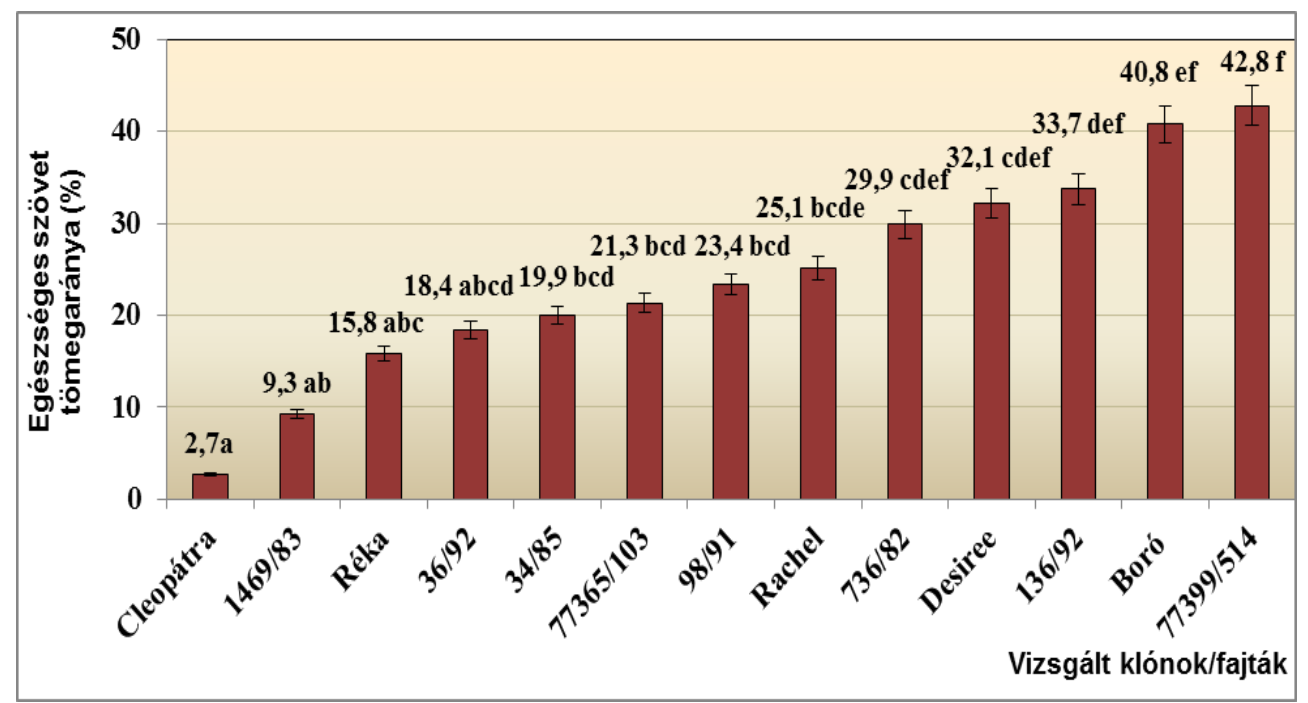

39. ábra. Üvegházi burgonyagumók átlagos fogékonysági értéke az Dickeya dadantiivel történő fertőzési kísérletének eredményei alapján. A fajták szignifikánsan $(\mathrm{p}<0,05)$ különböző csoportokba sorolását eltérő betűk jelölik

A klónok fertőzöttségi csoportosítása kategóriák szerint:

rezisztens: 'Desiree', 'Boró', 136/92 és a 77399/514

mérsékelten rezisztens: 736/82, 98/91, 77365/103 és a 'Rachel'

mérsékelten fogékony: 'Réka', 36/92 és a 34/85

fogékony: 1469/83

erősen fogékony: 'Cleopátra'

Ha a módszeren belül a két kórokozót hasonlítom össze, akkor elmondható, hogy 'Boró', a 136/92 és a 77399/514 mindkét baktériumfajjal szemben reisztensnek bizonyult. A 'Cleopátra' viszont az Dd-val szemben erösen fogékony volt, addig az Pcc-val szemben rezisztens lett. A 'Réka' és a 1469/83 mindkét baktériummal szemben fogékonynak bizonyult. 


\subsection{Almafajták fogékonysága}

Almafajták esetében in vitro hajtásfertőzési kísérleteket 2012 és 2013-ban végeztük. Az első megfigyelési időpontban, a fertőzést követő második napon kapott eredményeket a 40. ábra szemlélteti. A fertőzést követő rövid időtartam ellenére egyik fajta sem bizonyult tünetmentesnek. A 'Húsvéti rozmaring', a 'Red Fuji' és a 'Freedom' statisztikailag nem vált el egymástól. Ezek adták ebben a megfigyelési időpontban a legjobb eredményt. Ugyancsak azonos, mérsékelt fogékonyságú csoportba tartozott a 'Tenroy' (Royal Gala) és a 'Hesztia'. Szignifikánsan a 'Jonagold' esetében figyeltük meg a „legrosszabb” eredményt, mivel fertőzési indexe közel 1-es értékü volt.

A fertőzési index értékek 0,12 és 0,96 között alakultak. A tüneteket nézve ez annyit jelentett, hogy még a legfogékonyabb fajtánál is csak egy-két egyednél fordult elő az, hogy a fertőzés a megvágott levél főerére is átterjedt. Jellemzőbb volt, hogy a megvágott levél vágási felülete megbarnult, vagy el sem színeződött (40. ábra).

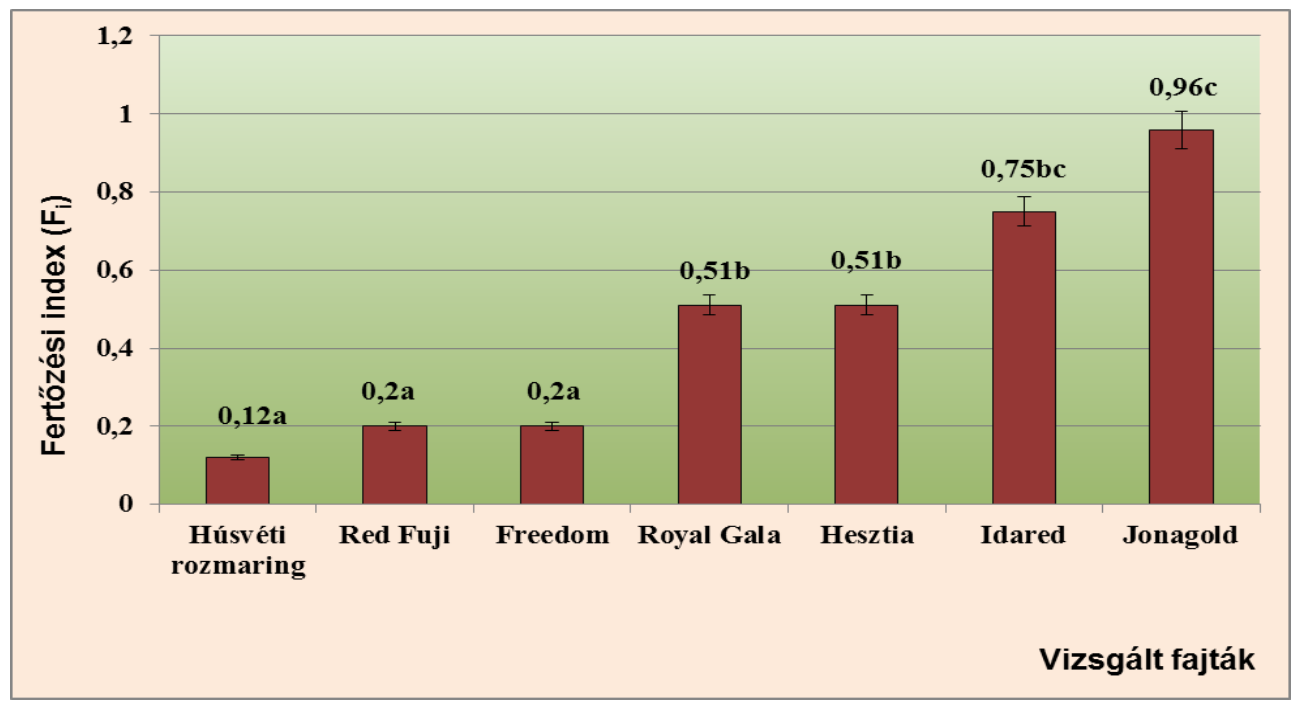

40. ábra. In vitro almahajtások átlagos fogékonysági értéke az Erwinia amylovora fertőzést követő második napon.

A fajták szignifikánsan $(\mathrm{p}<0,05)$ különböző csoportokba sorolását eltérő betük jelölik

A második megfigyelési időpontban (fertőzést követő ötödik nap) a legjobb eredményt a 'Red Fuji’ és a 'Freedom' esetében figyeltük meg, de ezektől a fajtáktól szignifikánsan nem vált el a 'Hesztia' értéke annak ellenére, hogy egy kicsit magasabb fertőzési indexet produkált $\left(F_{i}=2,32\right)$. A leggyengébb eredményt a 'Tenroy' (Royal Gala) és a 'Jonagold' adta, melyek között szintén nem tudtunk szignifikáns különbséget tenni annak ellenére, hogy fertőzési indexük jelentősen eltér és a vizuálisan megfigyelhető tüneteikben is szemmel látható különbség volt. Mérsékelt 
fogékonyságot figyeltünk meg az 'Idared' és a 'Húsvéti rozmaring' esetében, melyek statisztikailag szintén egy csoportot képeztek (41. ábra).

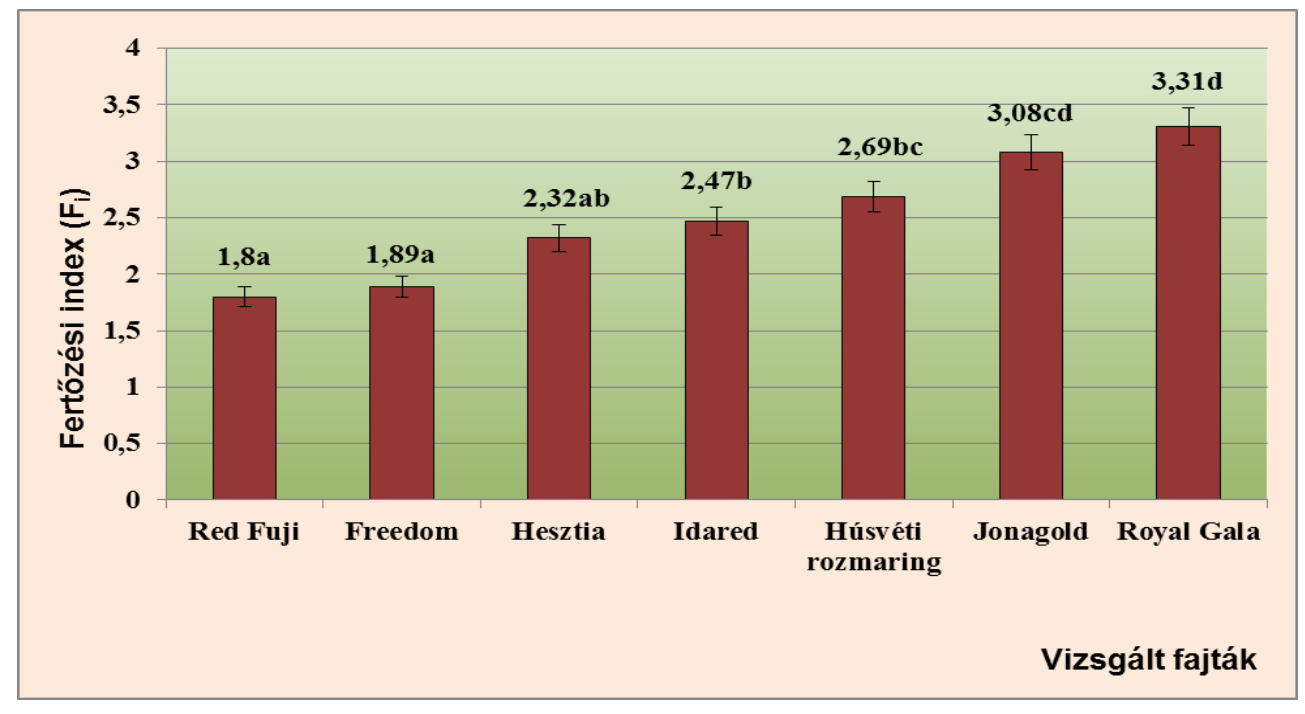

41. ábra. In vitro almahajtások átlagos fogékonysági értéke az Erwinia amylovora fertőzést követő ötödik napon.

A fajták szignifikánsan $(\mathrm{p}<0,05)$ különböző csoportokba sorolását eltérő betük jelölik

Az utolsó megfigyelési időpontban (fertőzést követő nyolcadik nap) a fajták kevésbé váltak el egymástól, mint az előző időpontban. Szignifikánsan itt is a 'Red Fuji' és a 'Freedom' esetében tapasztaltuk a legjobb eredményeket. Ezektől a fajtáktól szignifikánsan vált el az 'Idared', a 'Húsvéti rozmaring' és a 'Hesztia'. Legnagyobb fertőzöttség ebben a megfigyelési időpontban is a 'Tenroy' (Royal Gala) és a 'Jonagold esetében volt megfigyelhető. A fertőzési indexek 2,93 és 4,72 között alakultak (42. ábra és a 2. melléklet 22-23. táblázat). Mivel a legfogékonyabb fajták in vitro növényeinek $\mathrm{kb}$. $80 \%$-a elpusztult, ezért további megfigyeléseknek már nem láttuk értelmét.

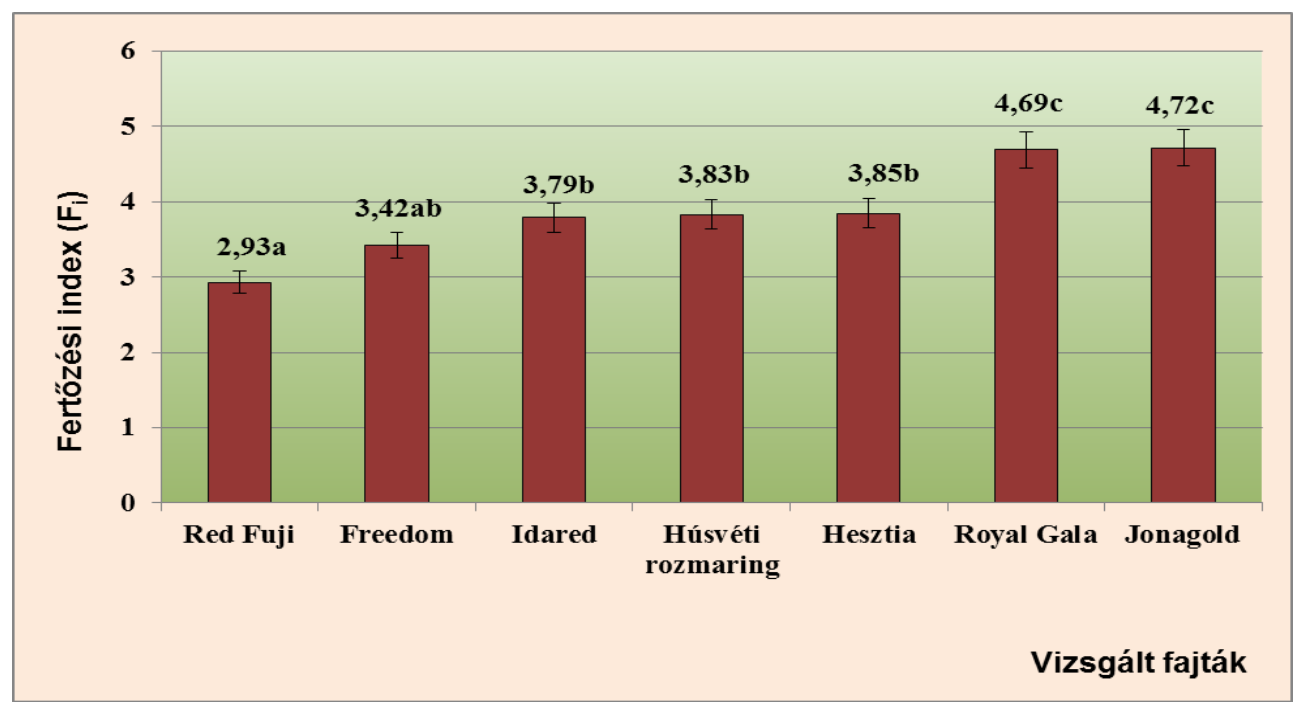

42. ábra. In vitro almahajtások átlagos fogékonysági értéke az Erwinia amylovora fertözést követö 8. napon. A fajták szignifikánsan $(\mathrm{p}<0,05)$ különböző csoportokba sorolását eltérő betük jelölik. 
A fertőzést követő ötödik napon kapott eredményeket figyelembe véve a következő kategóriákba sorolhatók a fajták:

rezisztens: 'Red Fuji' és a 'Freedom'

mérsékelten rezisztens: 'Hesztia'

mérsékelten fogékony: 'Idared', 'Húsvéti rozmaring' és a 'Jonagold'

erősen fogékony: 'Tenroy' (Royal Gala)

A kontroll kezelés során steril desztillált vízbe mártott ollóval vágtuk félbe a leveleket. A fajták ebben az esetben az őket ért mechanikai sérülésre reagáltak. A kontroll kezelés első két megfigyelési időpontjában statisztikailag nem volt különbség a fajták között (2. melléklet 23. táblázat). A megfigyelés harmadik napján viszont már volt statisztikai különbség a fajták között. A 'Húsvéti rozmaring', a 'Freedom' és a 'Tenroy' szignifikánsan érzékenyebbek voltak a mechanikai sérülésre, mint az 'Idared'. A 'Red Fuji', a 'Hesztia' és a 'Jonagold' mérsékelt érzékenységet mutattak az öket érő fizikai sérülésre. A mechanikai sérülés az 'Idared'-en okozta a legsúlyosabb elváltozásokat (43. ábra).

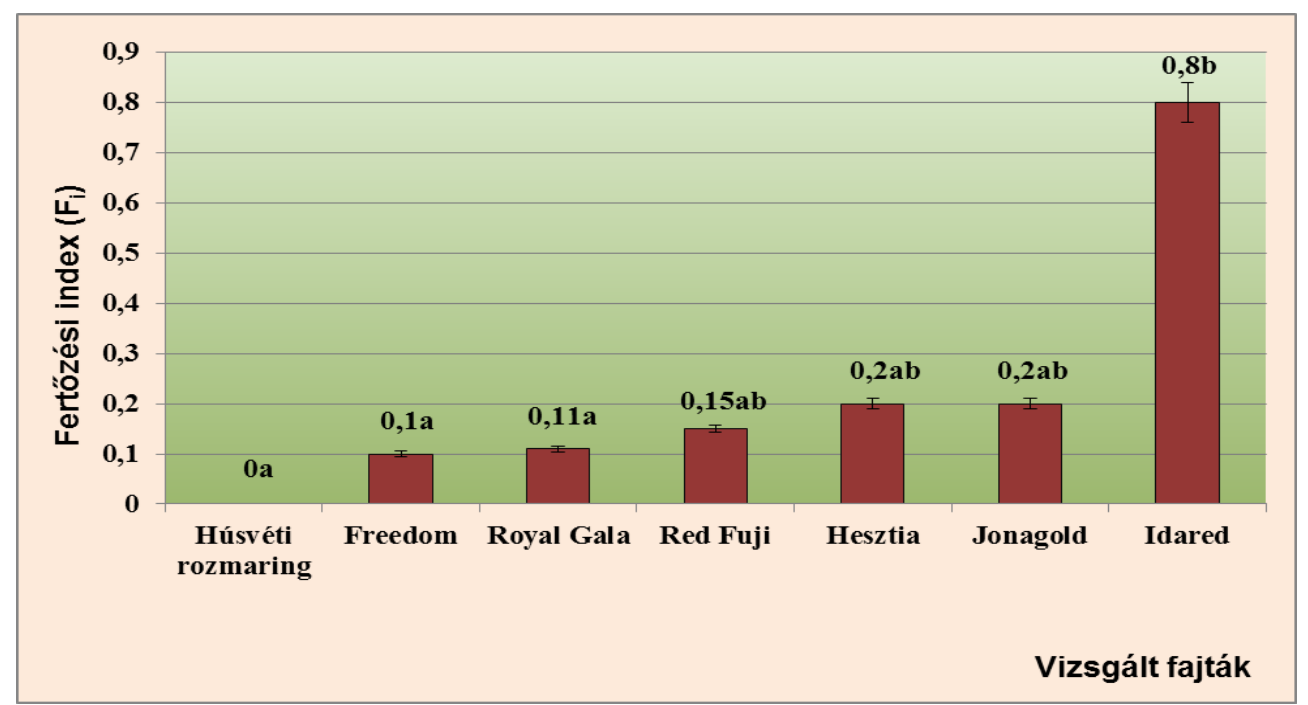

43. ábra. In vitro almahajtások átlagos fogékonysági értéke a kontroll kezelésben a harmadik megfigyelési időpontban (fertőzést követő nyolcadik napon). A fajták szignifikánsan $(p<0,05)$ különböző csoportokba sorolását eltérő betűk jelölik

\subsubsection{Baktérium sejtszám meghatározása}

In vitro almahajtások esetében is végeztünk visszaizolálásokat a fertőzött növényi részekből. Ennek eredményét a 44. ábra mutatja be, mely a különböző fogékonysági kategóriákba sorolt fajták visszaizolási eredményeit szemlélteti négy hígítás $\left(10^{-6}, 10^{-7}, 10^{-8}, 10^{-9}\right)$ alkalmazásával. A fertőzést követö ötödik napon végzett visszaizolálás szépen tükrözi a különböző fogékonyságú fajták in vitro hajtásában végbemenő baktérium sejtszaporodást. A 'Freedom' szemmel láthatóan különbözött a többi fajtától. Egy rezisztens fajtában a baktériumsejtek szaporodása is kisebb mértékű (Honty, 2010) és a mi eredményeink is ezt tükrözik. A 'Hesztia', 'Húsvéti 
rozmaring' és 'Tenroy’ (Royal Gala) eredményei már kevésbé látványosak, $10^{-6}$ hígításnál a 'Tenroy' esetében tapasztaltuk a legintenzívebb sejtszaporodást, ami egy erősen fogékony fajtánál teljesen logikus. Ha a nagyobb hígításokat vesszük figyelembe, láthatunk különbségeket a közepes fogékonyságú fajták között is. $10^{-8}$-as hígításnál a 'Hesztia' és a 'Húsvéti rozmaring' vizsgálatánál minimum tízszeres különbséget tapasztaltunk a kolóniák számában az utóbbi fajta javára . A fogékonyabb fajták értékeléséhez a nagyobb hígításokra $\left(10^{-8}, 10^{-9}\right)$ volt szükség. Az ábrán is jól látható, hogy a 'Freedom' és a 'Hesztia' mintáiból a $10^{-9}$-nál már nem tudtunk kolóniákat számolni, ezzel ellentétben a fogékonyabb 'Húsvéti rozmaring' és 'Tenroy' (Royal Gala) fajtáknál még ennél a hígításnál is számolhatóak a telepek.
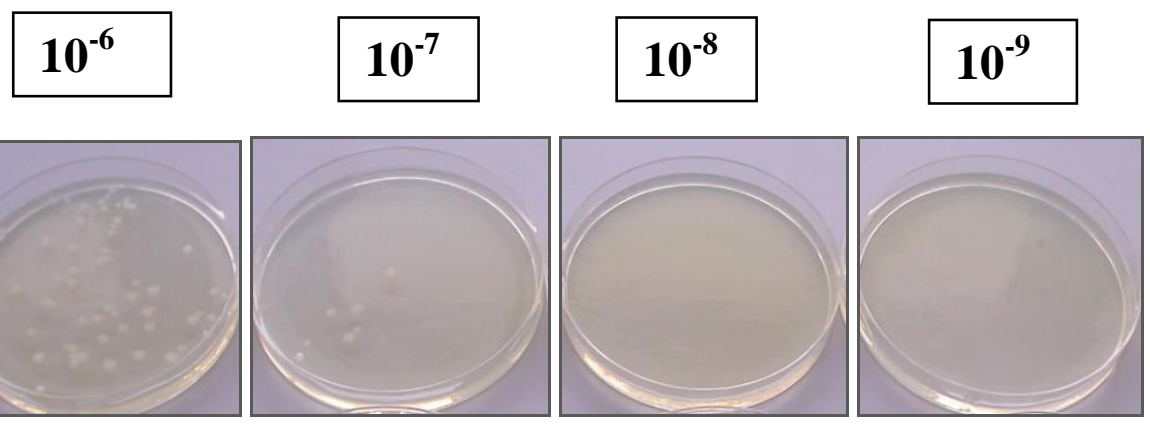

'Freedom'

(rezisztens)
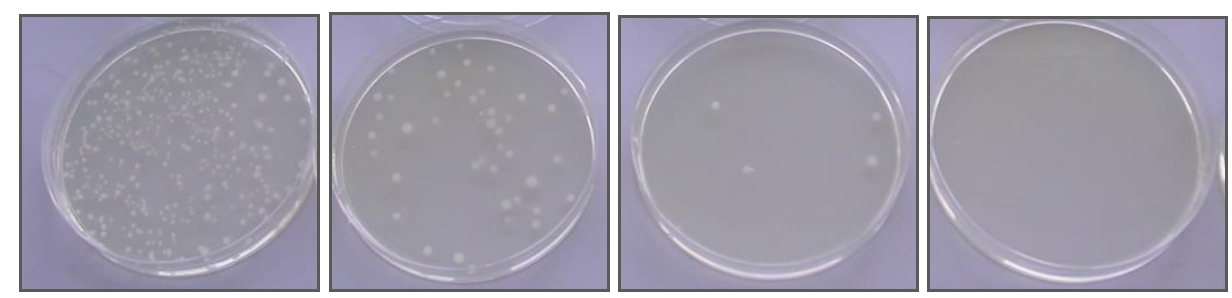

'Hesztia' (mérsékelten rezisztens)
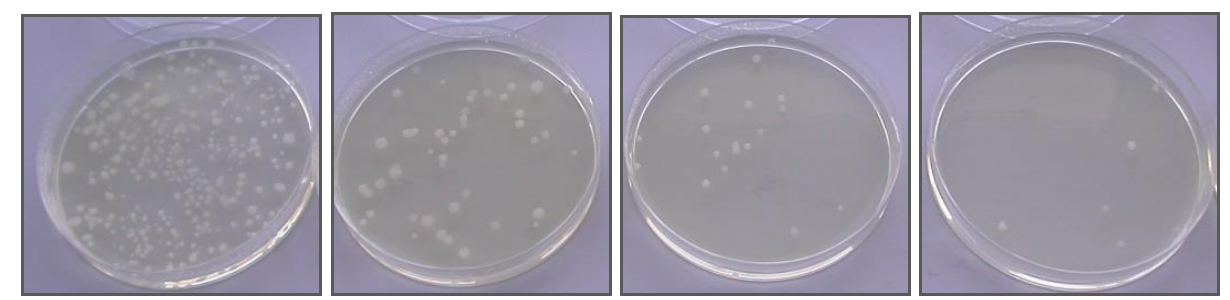

'Húsvéti rozmaring' (mérsékelten fogékony)
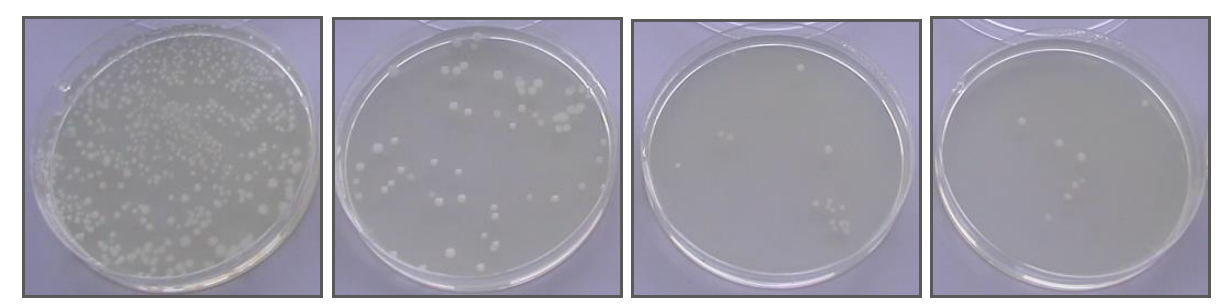

'Tenroy' (Royal Gala) (erösen fogékony)

44. ábra. 'Freedom', 'Hesztia', 'Húsvéti rozmaring' és 'Tenroy' (Royal Gala) almahajtásokbóll visszaizolált Erwinia amylovora kolóniák különböző hígításoknál 


\subsection{Biokémiai vizsgálatok eredményei}

Elökísérleteket végeztem annak kiderítésére, hogy a mikroszaporított burgonya és alma esetében a különböző fertőzések által okozott stressz nyomon követhető-e a peroxidáz enzimaktivitás és a szénhidráttartalom mérésekkel. Az elképzelés megvalósításának nehézsége az volt, hogy nagyon kicsi növénymintákkal dolgoztunk, egy-egy in vitro hajtásdarab súlya néhány mg volt. Sajnos ez magában rejti annak a lehetőségét, hogy nagyobb hibát tudtunk elkövetni. Ezért a kísérletek eredményeinek tárgyalásánál figyelembe kell venni a mintavételből származó hibákat, hiányosságokat. A biokémiai vizsgálatokhoz az in vitro növényfertőzés eredményei alapján választottuk ki a különböző fogékonyságú genotípusokat.

5.4.1. Peroxidáz enzimaktivitás változások Pectobacterium carotovorum subsp. carotovorum fertőzés következtében

A kiválasztott klónok: 77365/103 (rezisztens), 36/92 (mérsékelten fogékony) és 98/91 (erősen fogékony).

Az eredmények értékelésénél figyelembe kell venni, hogy volt olyan eset, mikor kevés növényanyag állt rendelkezésemre, ezért fordulhatott elö, hogy a 24 órás mintavételkor egy mintavételi helyről a mérsékelten fogékony klónból nem sikerült megfelelő súlyú mintát begyüjteni (45. ábra).

A fertőzést követő azonnali mintavételt (0 órás) tekintettük kontrollnak. Az itt kapott értékek jelentik a növények azon aktivitását, mellyel természetes módon rendelkeznek. Egyértelmüen látszik, hogy az eltérő fogékonyságú klónok között különbségek vannak aktivitásukat tekintve. Bár a szúrás feletti (F) szárrészben ez kevésbbé volt látványos, de a szúrás alatti (A) szárrészekben szépen látszik, hogy a rezisztens 77365/103 klónban (103,1 U/mg) több mint 30\%-kal magasabbak a POD értékek, mint az erősen fogékony 98/91 klónban (71,3 U/mg). A mérsékelten fogékony 36/92 aktivitása még az erősen fogékony klónnál is alacsonyabb volt (50,4 $\mathrm{U} / \mathrm{mg})$.

A fertőzés hatására a kontrollhoz képest változik a POD aktivitás a növényekben, mégpedig úgy, hogy a fertőzést követő harmadik óráig enyhén növekszik az enzimaktivitás, majd a fertőzést követő hatodik órában jelentősen lecsökken és ezt követően újra emelkedni kezd. Ez a tendencia különösen a rezisztens és erősen fogékony klónban követhető és legszembetünőbb a szúrás alatti (A) szárrészekben. Az enzimaktivitásban változás tehát a fertőzést követő hatodik órában mértük, amikor lecsökken a POD aktivitás. Ez a változás azonban nem tartós, a fertőzést követő 24 órával kiegyenlítődik, sőt még meg is haladhatja a kontroll értéket. Az erősen 
fogékony 98/91 klónban a kontrollhoz (71,3 U/mg) képest közel duplájára nő az enzimaktivitás a fertőzést követő 24 óra múlva $(132,5 \mathrm{U} / \mathrm{mg})$. A rezisztens 77365/103 klónban viszont kiegyenlítődik a POD értéke. A mérsékelten fogékony 36/92 klónban ugyancsak duplájára nő az enzimaktivitás a kontrollhoz képest 24 óra alatt. Úgy tünik, hogy a növény kompenzálni akarná a szöveteiben zajló változásokat, arra törekedve, hogy az eredeti állapotokat visszaállítsa (45. ábra).
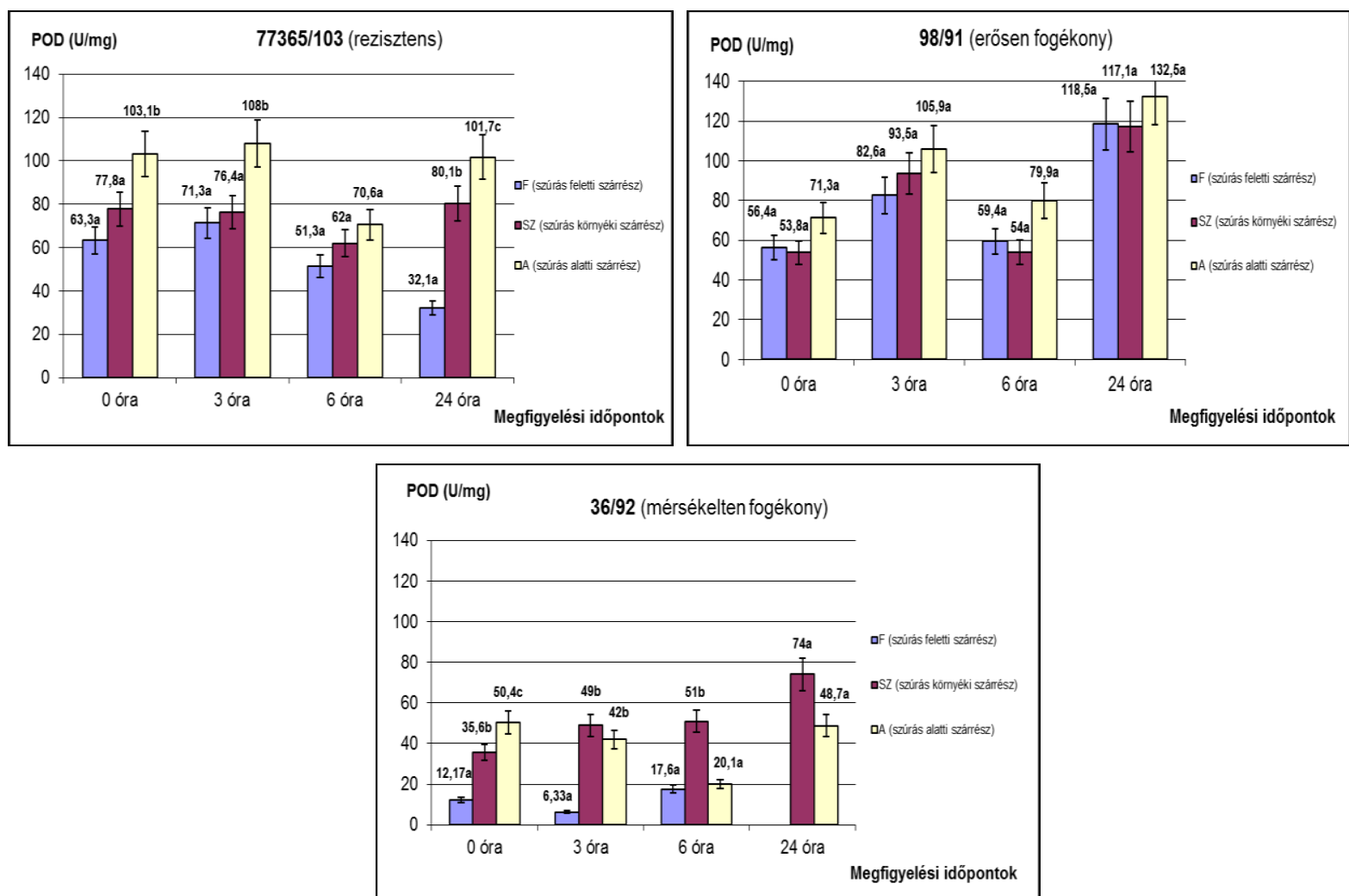

45. ábra. Peroxidáz enzimaktivitás változása a 77365/103 (rezisztens), a 36/92 (mérsékelten fogékony) és a 98/91 (erősen fogékony) in vitro burgonynövényekben Pectobacterium carotovorum subsp. carotovorum fertőzést követően

5.4.2. Szénhidráttartalom alakulása Pectobacterium carotovorum subsp. carotovorum fertőzés következtében

Burgonya esetében glükóz- és fruktóztartalmat mértünk. Kontrollnak továbbra is a közvetlenül a fertőzéssel egyidejü, 0 órás mintavétel eredményeit tekintettük. Ez volt az eltérő fogékonyságú in vitro növények endogén glükóztartalma. Az erősen fogékony 98/91 klónban figyeltük meg a legmagasabb glükóztartalmat $(0,245 \mathrm{mg} / \mathrm{g})$, megközelítőleg másfélszer több glükózt mértünk a szúrás alatti (A) szárrészekben, mint a rezisztens 77365/103 ugyanazon mintavételi helyén $(0,14$ $\mathrm{mg} / \mathrm{g})$ (46. ábra).

A fertőzés hatására a rezisztens 77365/103 klónban a kontrollhoz képest csökkenés indul meg a fertőzést követő harmadik és hatodik órában. A minimumot a hatodik órában éri el $(0,085$ 
mg/g), majd ezt követően emelkedni kezd és a fertőzés után 24 órával kiegyenlítődik a glükóz szint. Az erősen fogékony 98/91 klónban ugyanez a folyamat játszódik le, de a csökkenés nagyobb mértékü, 0,245 mg/g-ról lecsökken $0,17 \mathrm{mg} / \mathrm{g}$-ra. A fertőzést követő 24 óra múlva visszaáll a kontroll értékre a glükóz szint. A mérsékelten fogékony 36/92 klónban ugyanezt figyelhetjük meg, mint az eddigieknél, viszont a csökkenés mértéke itt a legkisebb, $0,115 \mathrm{mg} / \mathrm{g}$ ról $0,095 \mathrm{mg} / \mathrm{g}$-ra módosul a fertőzés után hat órával. Ekkor éri el a minimumát, de ezt követően emelkedni kezd a glükóz szint és 24 órával a fertőzés után meg is haladja a kontroll értéket. Tehát a glükóztartalomban bekövetkező változások a fertőzést követő három és hat óra közé tehetők, akárcsak az enzimaktivitás változásoknál. A folyamat során a glükóz szint minden esetben kiegyenlítődik, sőt meg is haladhatja a kontroll értéket (46. ábra).
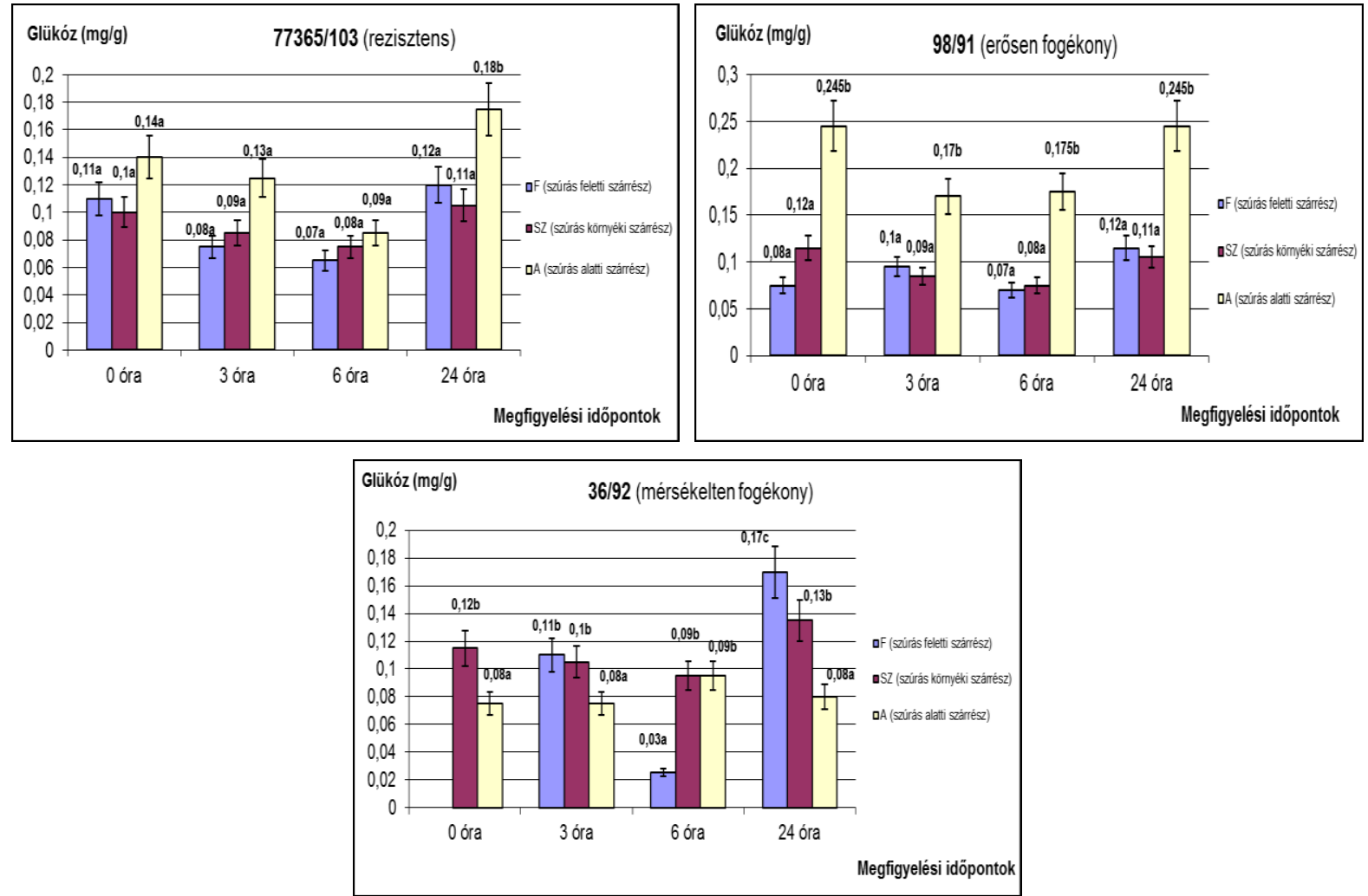

46. ábra. Glükóztartalom változás a 77365/103 (rezisztens), a 36/92 (mérsékelten fogékony) és a 98/91 (erősen fogékony) in vitro burgonynövényekben Pectobacterium carotovorum subsp. carotovorum fertözést követően

A kiindulási fruktóztartalmáról ugyanaz mondható el, mint a glükóz esetében. Az erősen fogékony klónban figyeltük meg a legmagasabb fruktóztartalmat $(0,24 \mathrm{mg} / \mathrm{g})$, ennél kb. $50 \%$-kal kisebb értéket mértünk a rezisztens klón ugyanazon szárrészében $(0,125 \mathrm{mg} / \mathrm{g})$.

A fertőzés hatására bekövetkező változások tendenciája ugyanaz, mint a glükóz esetében, de a változások markánsabbak. A fruktóz szint ebben az esetben is az inokulálást követő hatodik óráig csökken, majd emelkedni kezd és a 24. órára kiegyenlítődik, sőt minden esetben meg is haladja a kontroll értéket. A rezisztens klónban $0,125 \mathrm{mg} / \mathrm{g}$-ról $0,17 \mathrm{mg} / \mathrm{g}$-ra nő a fruktóz 
mennyisége. Az erősen fogékony klónban jóval kisebb mértékü a növekedés, $0,24 \mathrm{mg} / \mathrm{g}$-ról csupán 0,285 mg/g-ra változik. A legnagyobb változás a mérsékelten fogékony klónban következik be, itt duplájára nő a fruktóz mennyisége a fertőzés hatására a kezdeti értékekhez képest, 0,065 mg/g-ról 0,14 mg/g-ra emelkedik (47. ábra).
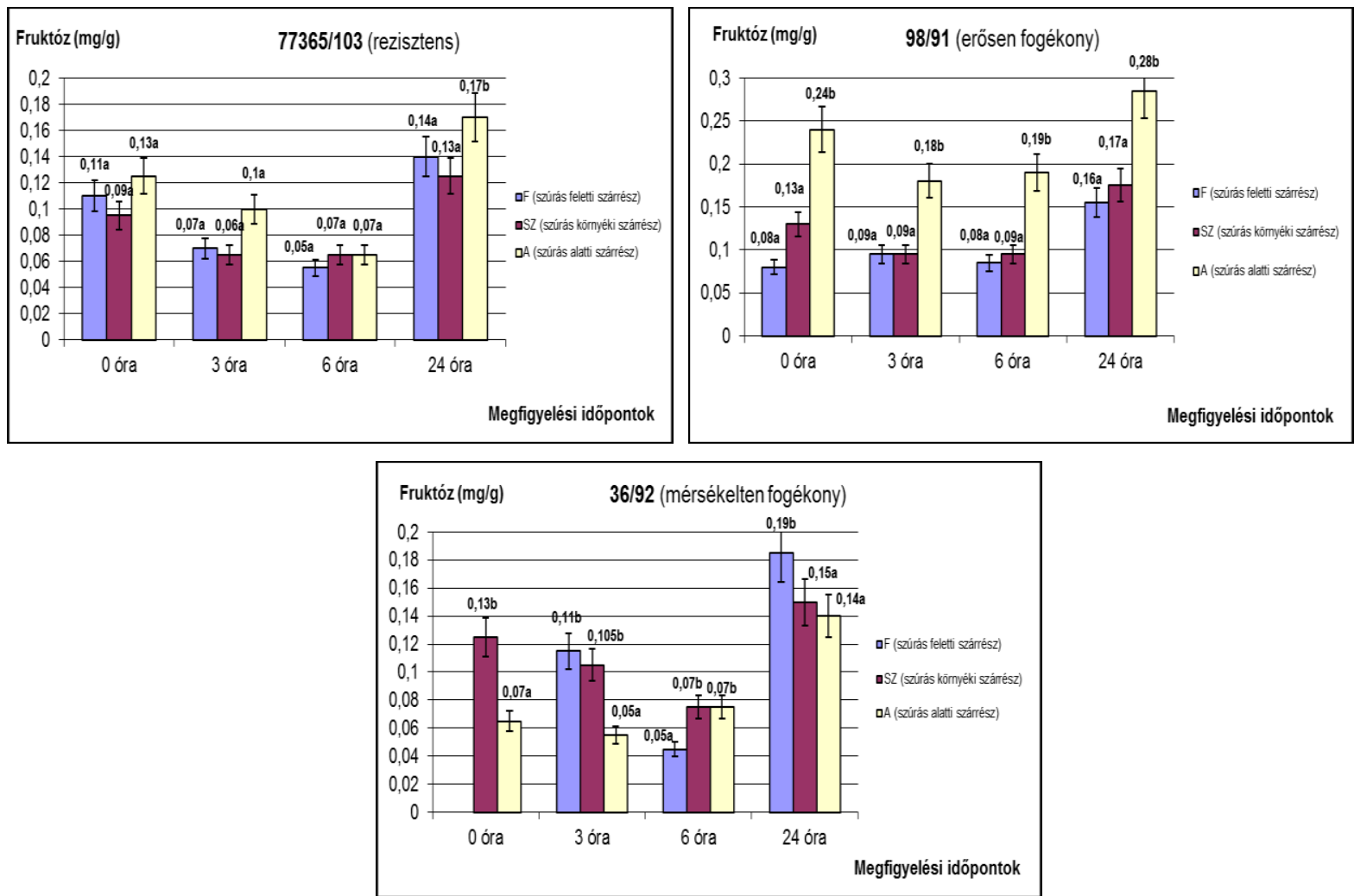

47. ábra. Fruktóztartalom változása a 77365/103 (rezisztens), a 36/92 (mérsékelten fogékony) és a 98/91 (erősen fogékony) in vitro burgonynövényekben Pectobacterium carotovorum subsp. carotovorum fertőzést követően

\subsubsection{Peroxidáz enzimaktivitás változások Dickeya dadantii fertőzés következtében}

A kiválasztott genotípusok: 34/85 (rezisztens), 'Réka' (mérsékelten fogékony) és 'Boró' (erösen fogékony).

Ebben az esetben is a 0 órás mintavételt vettük kontrollnak. A Pcc-nál tapasztaltakhoz hasonlóan itt is elmondható, hogy a különböző fogékonysággal rendelkező burgonya genotípusok aktivitása eltér egymástól. Ebben az esetben is a rezisztens 34/85 klónban mértük a magasabb POD aktivitást az erősen fogékony 'Boró' és a mérsékelten fogékony 'Réka'-hoz képest.

A kontrollhoz viszonyítva szintén bekövetkezik változás a fertőzés hatására, mely a rezisztens klónban és az erősen fogékony fajtában egy emelkedő tendenciát mutat. A mérsékelten fogékony fajtában van egy csökkenés a fertőzést követő harmadik órában, de ez kiegyenlítődik az utolsó mintavételi időpontra (24 óra). A kontrollhoz képest mindhárom fogékonyságú genotípusban 
emelkedik a POD aktivitás a 24. órára. Az erősen fogékony fajtában a szúrás környéki (SZ) szárrészekben a fertőzést követő 24. órára kb. duplájára nő az enzimaktivitás a kontrollhoz képest. 36,3 U/mg-ról $80 \mathrm{U} / \mathrm{mg}$-ra változik 24 óra alatt. A rezisztens klónban ez a növekedés kicsit kisebb, 74 U/mg-ról 137 U/mg-ra változik. Az, hogy a rezisztens klónban és az erősen fogékony fajtában a változások hasonlóak, az megegyezik az Pcc-nál tapasztaltakkal. Ez a változás viszont tartós, mivel feltételezhetően egy folyamatos emelkedésről van szó (48. ábra).
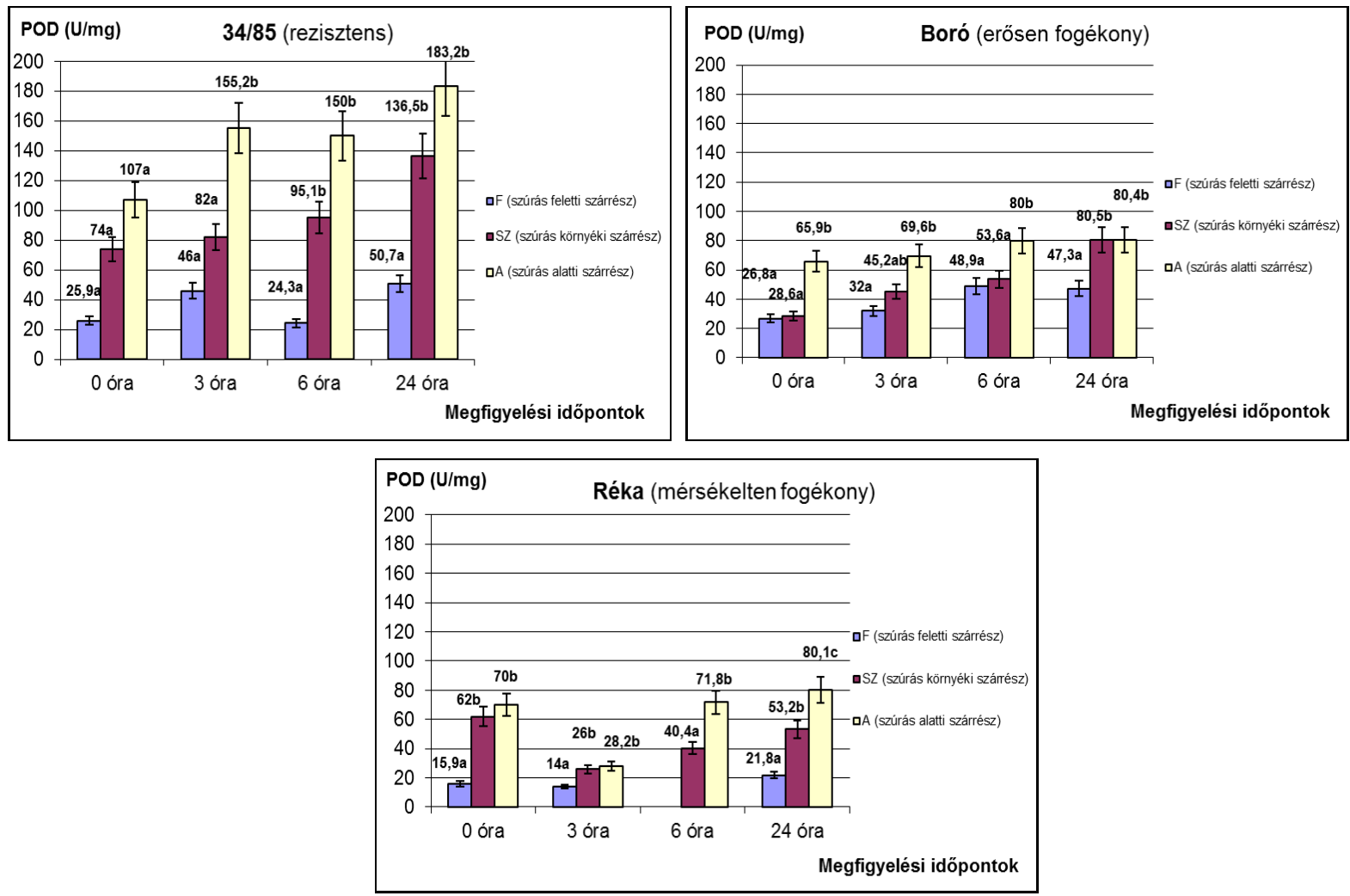

48. ábra. Peroxidáz enzimaktivitás változása a 34/85 (rezisztens), a 'Réka' (mérsékelten fogékony) és a 'Boró' (erősen fogékony) in vitro burgonynövényekben Dickeya dadantii fertözést követően

\subsubsection{Szénhidráttartalom alakulása Dickeya dadantii fertőzés következtében}

Sajnos hiányzó adatunk ebben az esetben is volt, a mérsékelten fogékony 'Réka' esetében a szúrás alatti (A) szárrészben nem tudtuk megmérni a kiindulási glükóz értéket.

A hiányosságok ellenére a szúrás alatti $(\mathrm{A})$ területeket vesszük figyelembe, akkor ugyanazt a megállapítást tehetjük, mint az $P c c$ esetében, azaz az erősen fogékony 'Boró' fajtában $(0,17$ mg/g) kétszer annyi glükóz van, mint a rezisztens 34/85 klónban (0,075 mg/g) (49. ábra).

$D d$-val történő fertőzés hatására a kontrollhoz képest egy folyamatos glükóz emelkedést tapasztaltunk, tehát nincs meg az a három és hat óra közötti csökkenés, amit a $P c c$-nál megfigyeltünk. A fertőzést követő 24 órával a rezisztens klónban a kontrollhoz képest több, mint húszszorosára emelkedett a glükóz mennyisége, $0,075 \mathrm{mg} / \mathrm{g}$-ról 1,845 mg/g-ra nőtt. A 
mérsékelten fogékony fajtában csökkent, míg az erősen fogékony fajtában $0,17 \mathrm{mg} / \mathrm{g}$-ról 0,72 mg/g-ra emelkedett, tehát közel megnégyszerezödött a glükóz mennyisége az inokulálást követő 24 óra alatt (49. ábra).
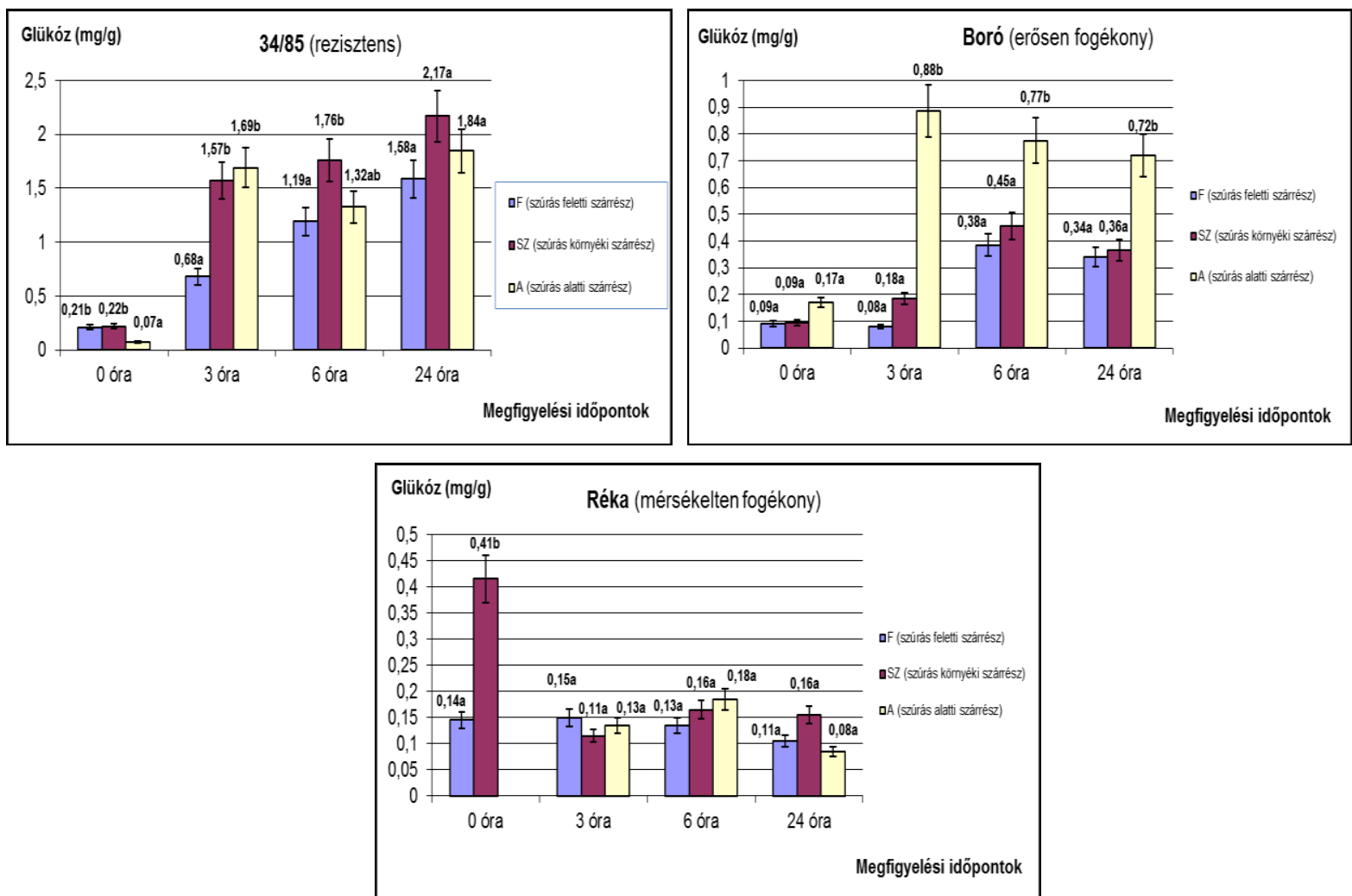

49. ábra. Glükóztartalom változása a 34/85 (rezisztens), a 'Réka' (mérsékelten fogékony) és a 'Boró' (erősen fogékony) in vitro burgonynövényekben Dickeya dadantii fertőzést követően

A rezisztens klónt összehasonlítva az erősen fogékony fajtával a kezdeti fruktóztartalmat tekintve már nem mondható el az, ami a korábbiakban jellemző volt. Az erösen fogékony fajtában kisebb vagy közel azonos a fruktóz mennyisége $(0,075 \mathrm{mg} / \mathrm{g})$, mint a rezisztens klónban $(0,095 \mathrm{mg} / \mathrm{g})(50$. ábra).

A fertőzés hatására tulajdonképpen ugyanaz a tendencia érvényesül, mint a glükóz esetében, tehát a fertőzés egy folyamatos fruktóz szint emelkedést indukál. A rezisztens klónban a kontrollhoz képest 24 óra alatt harmincszorosára nőtt meg a fruktóz mennyisége a fertőzött szövetekben, egész pontosan a szúrás környéki (SZ) szárrészekben, azaz 0,07 mg/g-ról 2,195 $\mathrm{mg} / \mathrm{g}$-ra változott. Az erősen fogékony fajtában viszont ez az emelkedés hatvanszoros volt, 0,015 mg/g-ról 0,895 mg/g-ra emelkedett meg a fruktóz mennyisége az inokuláció hatására (50. ábra). 

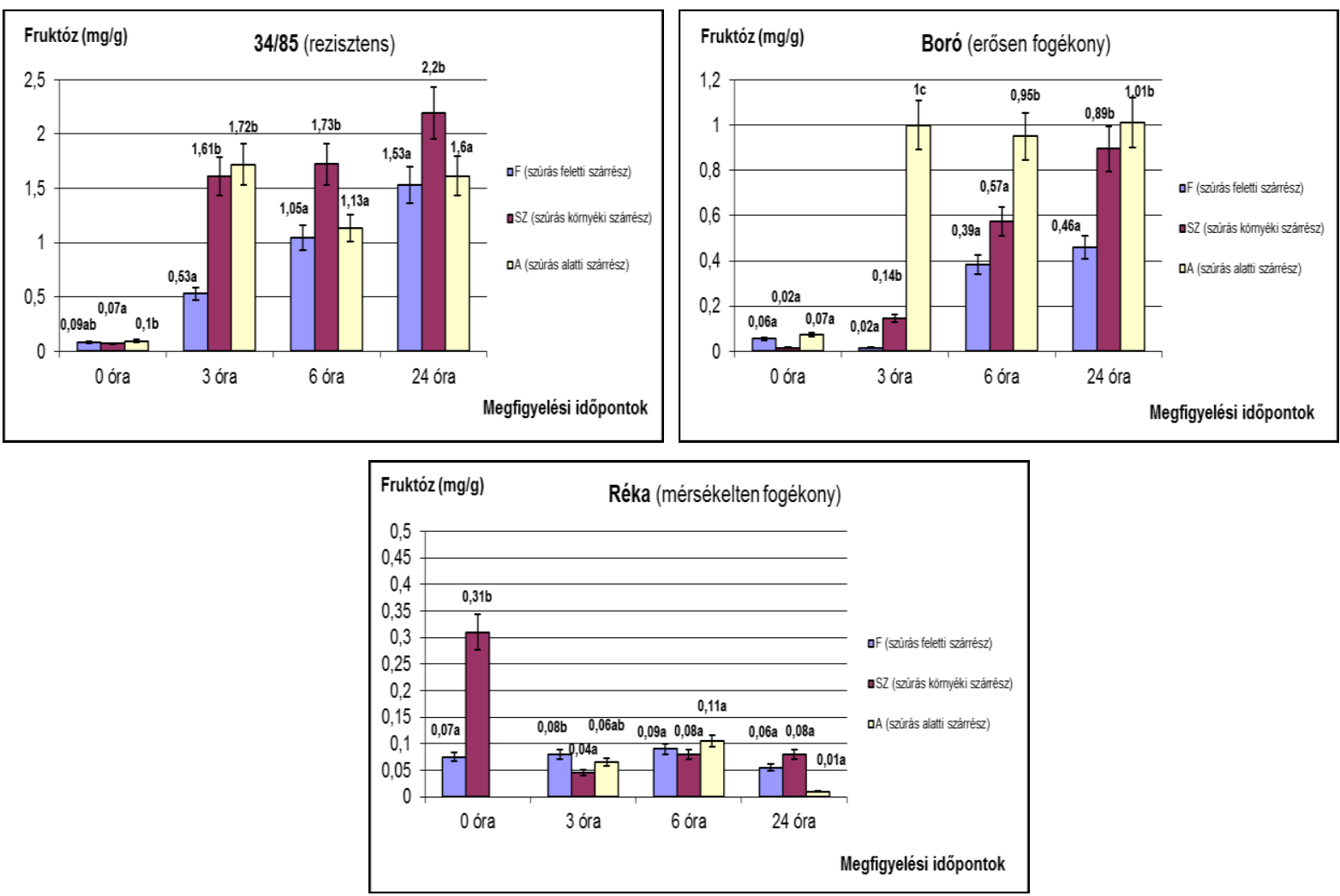

50. ábra. Fruktóztartalom változása a 34/85 (rezisztens), a 'Réka' (mérsékelten fogékony) és a 'Boró’ (erősen fogékony) in vitro burgonynövényekben Dickeya dadantii fertőzést követően

\subsubsection{Peroxidáz enzimaktivitás változások Erwinia amylovora fertőzés következtében}

A kiválasztott fajták: 'Freedom' (rezisztens), 'Húsvéti rozmaring' (mérsékelten fogékony) és ‘Tenroy' (Royal Gala) (erösen fogékony) fajta.

Alma esetében is a fertőzést követő azonnali mintavételt ( 0 órás) vettük kontrollnak. A legmagasabb aktivitást a rezisztens 'Freedom' fajta mutatta és a fogékonyság növekedésével csökkent a fajták kiindulási aktivitása. A rezisztens fajtáé 49,8 U/mg, a mérsékelten fogékony fajtáé $42 \mathrm{U} / \mathrm{mg}$, míg az erősen fogékonyé 18,6 U/mg volt (51. ábra).

A fertőzés hatására a kontrollhoz képest történt változás, mégpedig mindhárom fogékonyságú fajtában hasonló tendencia érvényesül. A változás a fertőzés után 24 órával következik be, ekkor egy csökkenés figyelhető meg az enzimaktivitásban, amit egy emelkedés követ. A rezisztens fajtában nem tartós változásról van szó, hiszen a fertőzés utáni 72. órára kiegyenlítődik az enzimaktivitás. A mérsékelten fogékony és az erősen fogékony fajtában folyamatos emelkedés figyelhető meg a 24. órás csökkenés után. Ez a növekedés a fertőzést követő 72. órára meg is haladja a kontroll értéket. Feltételezhetően a rezisztens fajtában a kiegyenlítődés szintén megtörténik, csak a fertőzést követő 120. óra után. Az erősen fogékony fajtában duplájára nőtt a POD aktivitás a kontrollhoz képest, 18,6 U/mg-ról 38,1 U/mg-ra nőtt. Ez a változás megegyezik az Pcc-nál tapasztaltakkal. A rezisztens fajtában végbemenő folyamatok szintén hasonlóak az Pcc-nál tapasztaltakkal. Ami az utolsó mintavételi időpontban mért eredményeket illeti, nem volt 
nagy különbség a rezisztens $(38,7 \mathrm{U} / \mathrm{mg})$ és az erősen fogékony fajta $(38,1 \mathrm{U} / \mathrm{mg})$ enzimaktivitása között (51. ábra).
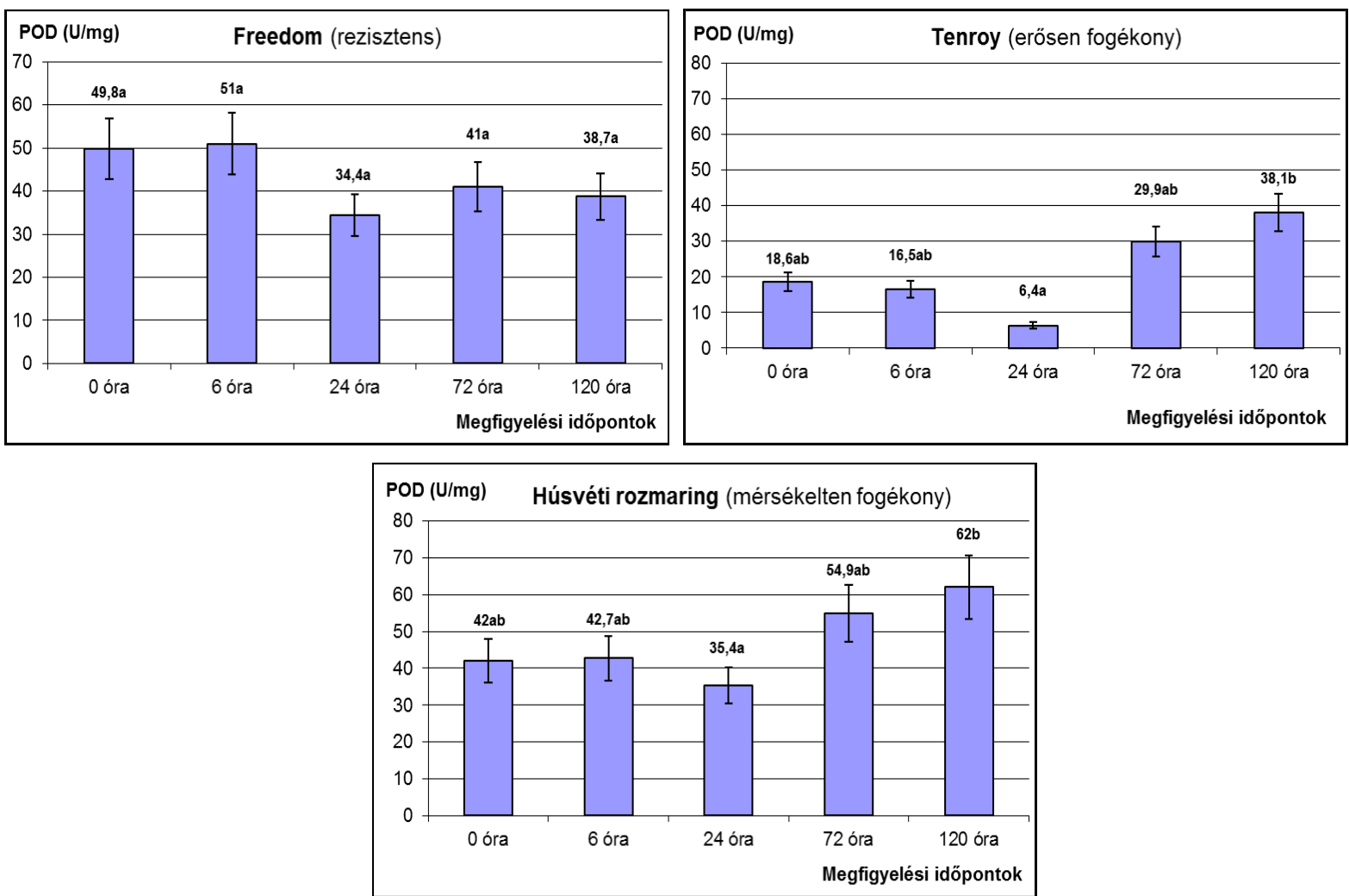

51. ábra. Peroxidáz enzimaktivitás változása a ‘Freedom’ (rezisztens), a ‘Húsvéti rozmaring' (mérsékelten fogékony) és a 'Tenroy' (erösen fogékony) in vitro almanövényekben Erwinia amylovora fertőzést követően

\subsubsection{Szénhidráttartalom alakulása Erwinia amylovora fertőzés következtében}

In vitro almanövényekben glükózt, fruktózt, szacharózt és D-szorbitolt mértünk. Hasonlóan az előzőekhez, ebben az esetben is a 0 órás eredményeket tekintettük kontrollnak. Az eltérő fogékonyságú fajták kontroll értékei között nagy különbségeket nem tapasztaltunk a glükóztartalomban. A rezisztens fajta glükóztartalma $1,285 \mathrm{mg} / \mathrm{g}$ volt, a mérsékelten fogékony fajtáé $1,275 \mathrm{mg} / \mathrm{g}$, míg az erősen fogékonyban 1,335 mg/g értéket mértünk (52. ábra).

A rezisztens fajtában a fertőzés hatására kismértékű cukornövekedés következett be, ami a maximumát a fertőzést követő 24 órával érte el és ezután folyamatosan csökkent. Az utolsó mintavételi időpontban (120 óra) a kontroll szintje alá süllyedt a glükóz értéke. Az erősen fogékony fajtában az első 24 órában cukorcsökkenést tapasztaltunk, majd a 24. órát követően emelkedett a glükóz mennyisége a fertőzött szövetekben, aztán újra csökkenni kezdett. A kontroll értékhez képest közel 50 \%-kal csökkent a glükóz szintje a fertőzés után 120 órával. A mérsékelten fogékony fajtában szintén egy kezdeti cukorcsökkenés figyelhető meg, ami a fertőzést követő 6 . órában éri el a minimumát. Ezután egy emelkedés következik, ami a 72. óráig 
tart és aztán újra csökkenni kezd a glükóz mennyisége, mégpedig a kontroll értéke alá süllyed (52. ábra).
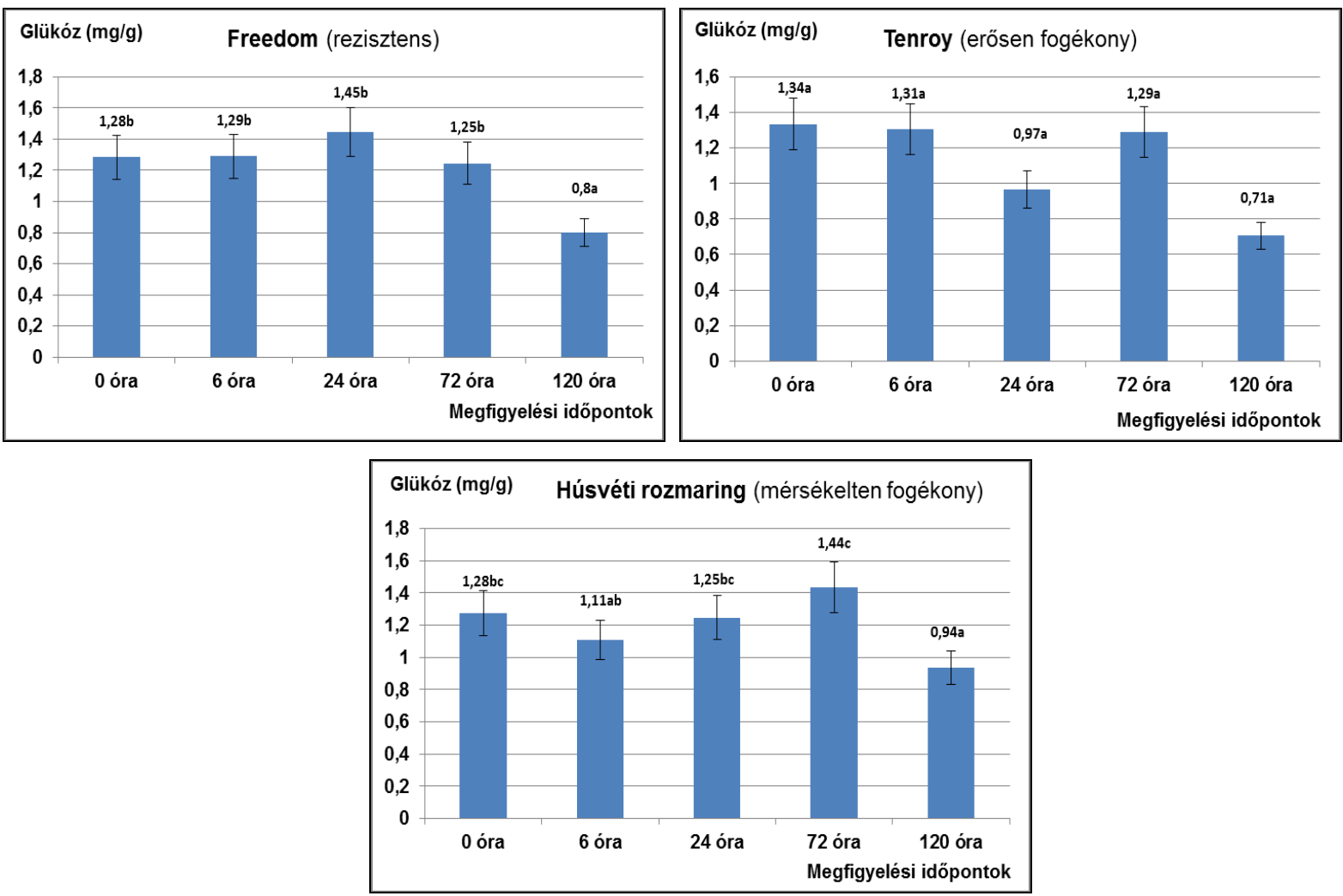

52. ábra. Glükóztartalom változása a 'Freedom' (rezisztens), a 'Húsvéti rozmaring' (mérsékelten fogékony) és a

‘Tenroy’ (erősen fogékony) in vitro almanövényekben Erwinia amylovora fertőzést követően

A rezisztens fajtában mértük a legmagasabb fruktóztartalmat $(0,405 \mathrm{mg} / \mathrm{g})$, ami közel kétszerese volt a mérsékelten fogékony fajtában $(0,165 \mathrm{mg} / \mathrm{g})$ és az erősen fogékony fajtában $(0,235 \mathrm{mg} / \mathrm{g})$ mértekhez képest (53. ábra).

A rezisztens fajtában a fertőzés számottevő csökkenést nem indukál, a fertőzést követő 24 órában folyamatosan nő a fruktóz mennyisége, meghaladja a kiindulási kontroll szintet is, majd a 24. órás maximumot követően csökkenni kezd, a 120. órára a kontroll érték kevesebb, mint felére süllyed le a fertőzött szövetek fruktóz mennyisége. Hasonló tendenciát figyelhettünk meg a mérsékelten fogékony fajtában is. Az erősen fogékonyban viszont a fertőzés hatására cukoremelkedés történt, majd a fertőzés után 6 órával csökkenni kezd a fruktóz mennyisége, ami a minimumát a 24. órában éri el. Ezt követően ismét megemelkedik és a fertőzés után 120 órával újra csökken. A csökkenés mértéke teljesen hasonló a rezisztens fajtában tapasztaltakkal, ebben az esetben is kevesebb, mint a kontroll érték felére esik vissza a fruktóz mennyisége a kezdeti értékekhez képest, $0,235 \mathrm{mg} / \mathrm{g}$-ról csökken le $0,1 \mathrm{mg} / \mathrm{g}$-ra (53. ábra). 

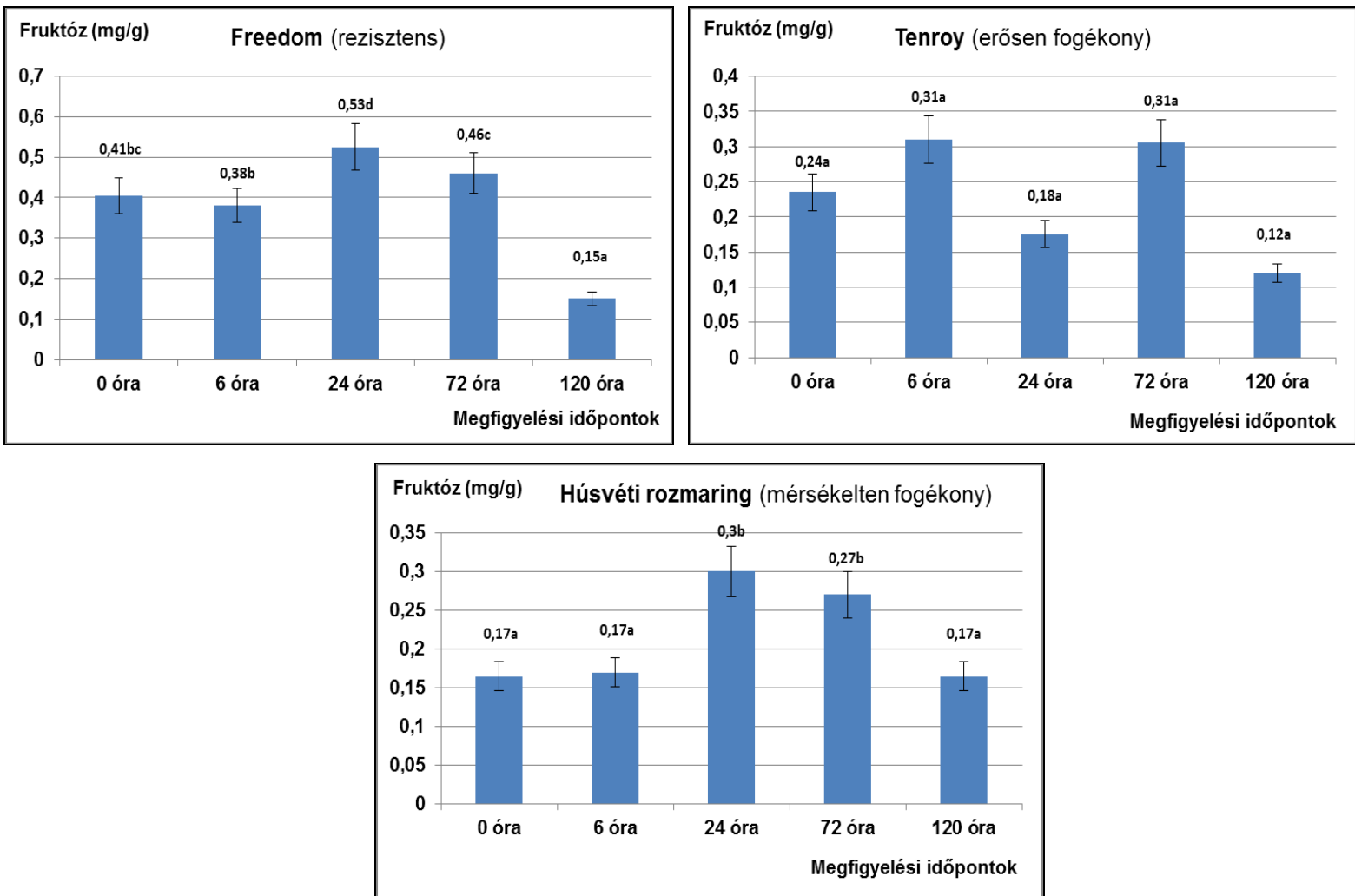

53. ábra. Fruktóztartalom változása a 'Freedom’ (rezisztens), a 'Húsvéti rozmaring' (mérsékelten fogékony) és a ‘Tenroy' (erösen fogékony) in vitro almanövényekben Erwinia amylovora fertőzést követően

A kontroll szacharóz értékeket megfigyelve elmondható, hogy a rezisztens és az erősen fogékony fajtában azonos értéket $(0,045 \mathrm{mg} / \mathrm{g})$ kaptunk, ezzel szemben a mérsékelten fogékony fajtában $(0,015 \mathrm{mg} / \mathrm{g})$ az előzőek harmada volt a kezdeti szacharóztartalom (54. ábra).

A fertőzés hatására a rezisztens fajtában majdnem a duplájára nő a szacharóz mennyisége az első 24 órában, egész pontosan 0,045 mg/g-ról 0,075 mg/g-ra változik. Ezt követően csökkenni kezd és a 120. órára kiegyenlítődik, visszaáll a kiindulási szacharóz szint $(0,05 \mathrm{mg} / \mathrm{g})$. Ezzel ellentétben az erősen fogékony fajtában a fertőzés utáni 24 órában folyamatos csökkenést tapasztaltunk, mely a minimumát a 24. órában érte el $(0,0055 \mathrm{mg} / \mathrm{g})$ és ezt követően folyamatosan nő és az előzőhöz hasonlóan a 120. órára szintén megtörténik a kiegyenlítődés (54. ábra). 

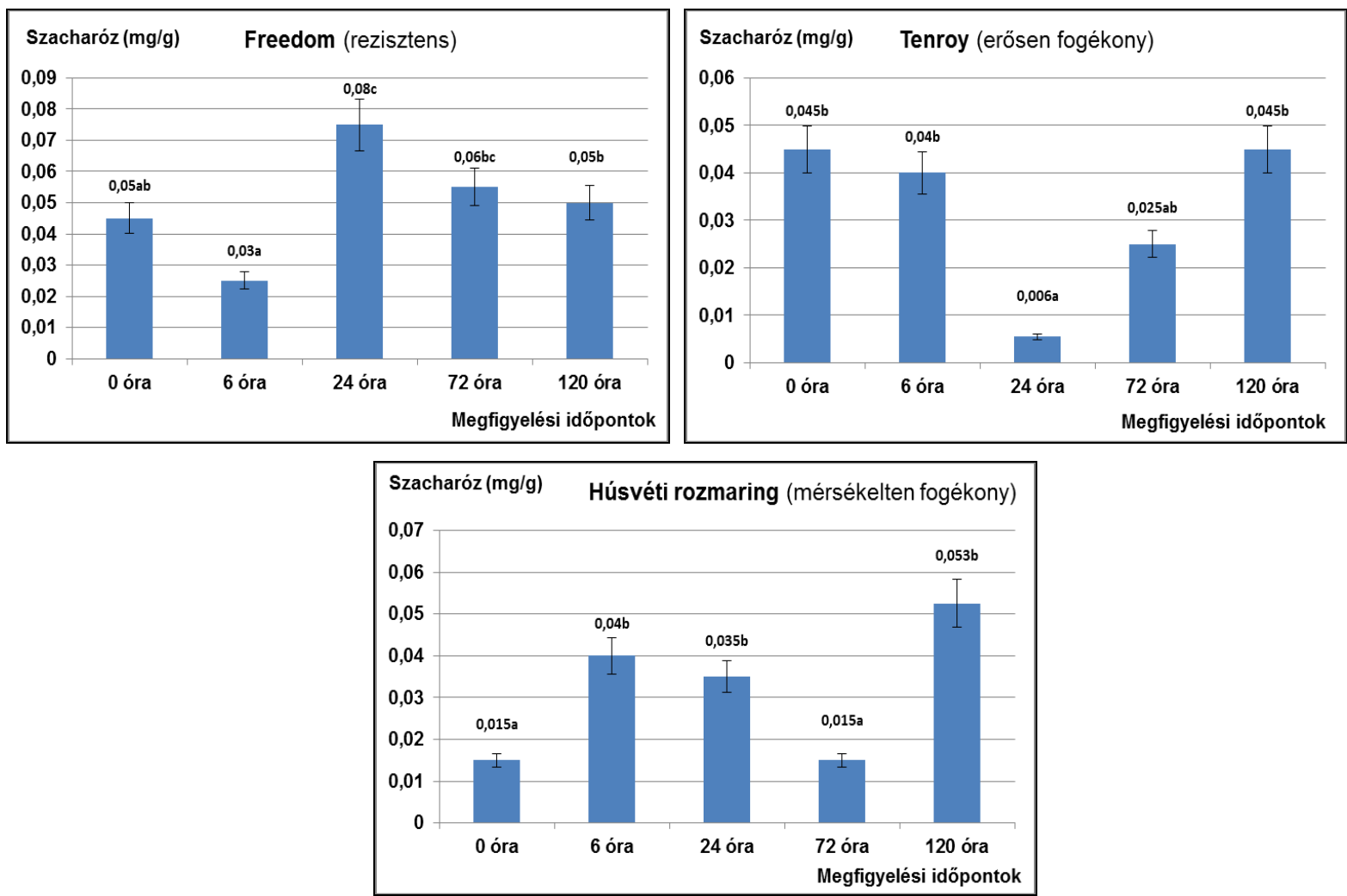

54. ábra. Szacharóztartalom változása a 'Freedom’ (rezisztens), a ‘Húsvéti rozmaring' (mérsékelten fogékony) és a

‘Tenroy’ (erősen fogékony) in vitro almanövényekben Erwinia amylovora fertőzést követően

A kontroll D-szorbitol értékeket összehasonlítva elmondható, hogy a legmagasabb értéket az erősen fogékony fajtában mértünk $(0,54 \mathrm{mg} / \mathrm{g})$, ennél alacsonyabb volt a rezisztens fajtában kapott érték $(0,44 \mathrm{mg} / \mathrm{g})$ és a legalacsonyabb a mérsékelten fogékony fajtában volt $(0,315 \mathrm{mg} / \mathrm{g})$ (55. ábra).

A fertőzés hatására a rezisztens fajtában cukoremelkedést tapasztaltunk, a legmagasabb értéket a fertőzés után 24 órával sikerült kimutatni $(0,55 \mathrm{mg} / \mathrm{g})$, majd ezt egy folyamatos csökkenés követte és a 120. órára teljesen kiegyenlítődika D-szorbitol értéke. A mérsékelten fogékony fajtában szintén egy maximumot figyeltünk meg a fertőzés után 24-72 órával, amit szintén egy csökkenés követ és az utolsó megfigyelési időpontban (120 óra) már a kontroll szintje alá süllyed a D-szorbitol mennyisége. Az erősen fogékony fajtában a fertőzés hatására egy cukorcsökkenés következik be, mely a 24. óráig tart, ez után megemelkedik a D-szorbitol szint a fertőzött szövetekben. A 72 . órás maximumot $(0,655 \mathrm{mg} / \mathrm{g})$ követően egy jelentős csökkenés következik be, a 120. órára $0,13 \mathrm{mg} / \mathrm{g}$-ra csökken a cukor mennyisége, tehát jelentősen a kontroll szintje alá süllyed (55. ábra). 

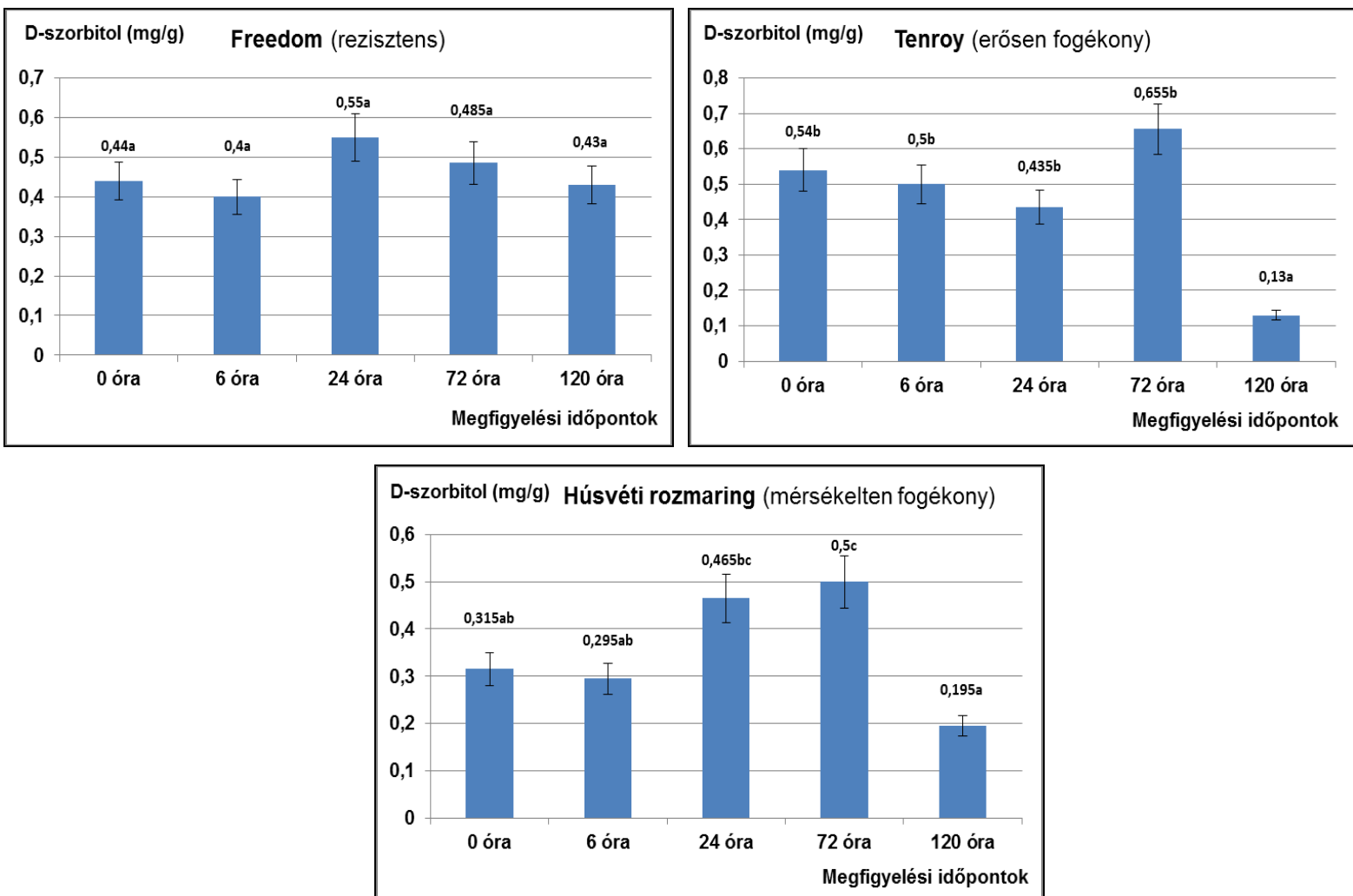

55. ábra. D-szorbitol-tartalom változása a 'Freedom' (rezisztens), a 'Húsvéti rozmaring' (mérsékelten fogékony) és a 'Tenroy' (erösen fogékony) in vitro almanövényekben Erwinia amylovora fertőzést követően 


\section{5. Új tudományos eredmények}

Az új tudományos eredményeket az alábbiak szerint foglalom össze:

1. Új fertőzési eljárást dolgoztunk ki a lágyrothadás betegséget okozó Erwinia fajokkal szembeni ellenállóság gyors és megbízható tesztelésére mikroszaporított burgonyanövények és mikrogumók bevonásával.

2. Megállapítottam, hogy a burgonyafajták ellenállóságának mértéke az in vitro hajtásokon jelentkező tünetekkel jellemezhető legmegbízhatóbban az általam vizsgált módszerek közül.

3. A hajtás és gumó összesített adatainak ismeretében a fajtákat és nemesítési klónokat különböző fogékonysági kategóriákba soroltam, fontos információkat szolgáltatva a hagyományos burgonyanemesítés számára.

4. Elsőként hasonlítottam össze lágyrothadás és hajtásszáradás betegségek során végbemenő növényi válaszreakciókat a peroxidáz stresszenzim és néhány fontosabb cukor változása alapján. Megállapítottam, hogy a gazdanövény azonos módon reagál a különböző betegségtípusokra.

5. Mikroszaporított növények bevonásával elsőként bizonyítottam a biokémiai markerek alkalmasságát a fajták stressztürésének meghatározására. A vizsgált biokémiai paraméterek közül a peroxidáz enzimaktivitás jellemezte leginkább mind a burgonya lágyrothadásának, mind pedig az alma hajtásszáradásának kórfolyamatát. A szénhidrátok közül alma esetében a szacharózban mutatkoztak meg a legnagyobb különbségek a rezisztens és fogékony fajtákban, míg burgonya esetében mindkét baktériumfajnál a fruktóz változása volt a legjellemzőbb.

6. Az in vitro burgonya és almahajtások vizsgálati és értékelési módszerét kiegészítettem a fertőzött növényi szövetekben lévő baktériumok visszaizolálásával és telepszámlálásával. 


\section{MEGVITATÁS, KÖVETKEZTETÉSEK}

Az in vitro módszereknek nemcsak a fajtafenntartásban, szaporítóanyag előállításban van jelentősége, hanem a növénynemesítésben is. A mikroszaporított tenyészeteket sikeresen használhatjuk különböző kórokozók, akár karantén kórokozók tesztelésére is, mivel steril körülmények között, biztonságosan folynak a mesterséges fertőzések és megfigyelések, a kísérleti anyag a vizsgálatok után megsemmisíthető, a kórokozó kiszabadulásának veszélye nélkül. Mikroszaporított növények egész évben rendelkezésre állnak; előállításuk kevésbé költséges, mint a kifejlett növényeké és a mesterséges fertőzések is standard körülmények között végezhetők, nem kell számolni az időjárás kiszámíthatatlanságával.

Dolgozatomban olyan gazdaságilag jelentős növénybetegségekkel foglalkoztam, mint a burgonya fekete szártőrothadása és a gumó nedves rothadása (Pectobacterium carotovorum subsp. carotovorum és Dickeya dadantii), valamint az alma tüzelhalása (Erwinia amylovora).

Ezen baktériumfajok patogenitásának in vitro tesztelése során számos, a további kutatások során hasznosítható tapasztalatot szereztünk.

Az in vitro burgonyanövények fertőzésénél először is a tüneteket állapítottuk meg a fertőzést követő egy hét elteltével. Ennyi időre volt szükség, hogy a fajták, illetve nemesítési klónok közötti fogékonyságbeli különbségek jól láthatóvá váljanak és értékelni tudjuk őket. Mind az $P c c$, mind a $D d$-val történő fertőzések során hasonló tüneteket kaptunk, csak a tünetek erősségében voltak eltérések.

Összehasonlítva az in vitro burgonyanövények mindkét baktériumfajjal történő fertőzési kísérleteinek eredményeit, megállapíthatjuk, hogy az $P c c$ agresszívabb baktériumfaj, súlyosabb tüneteket idézett elő az in vitro növényeken, mint az $D d$. A burgonya genotípusok nem azonosan reagáltak a különböző kórokozókra. Hasonló reakciót mutattak mindkét baktériumfajjal szemben a következő genotípusok: 77399/514 és a 'Cleopátra' mérsékelten rezisztens; 36/92 és a 'Desiree' mérsékelten fogékony; 'Boró' erősen fogékony.

Az Pcc-val szemben perspektivikusaknak a 77365/103 klónt és a 'Rachel' fajtát tekinthetjük. A $D d$-val szemben viszont a 34/85 klón tekinthető perspektivikusnak.

Sajnos a szakirodalomban nagyon kevés adat áll rendelkezésre, hogy a kereskedelmi burgonyafajták milyen fogékonysággal bírnak a Pectobacterium és Dickeya fajokkal szemben. A szakirodalom alapján (Tzeng et al., 1990) fogékonynak tekinthető a 'Kondor', a 'Flamenco', közepesen fogékony a 'Ciklámen', 'Góliát' és 'Russat Burbank', kevéssé fogékony a 'Desiree', 'Sarolta' és 'Cleopátra' fajta. Vizsgálataink egy része nemesítési klónokra vonatkozott, mivel 
feltételeztük, hogy az in vitro génbankunkban vannak olyan klónok, melyek leszármazottai között vad Solanum fajok is szerepelnek. A kísérletbe bevont nemesítési klónokról és a Nyíregyházán nemesített fajtákról ('Rachel', 'Boró' és 'Réka') ezek az első ilyen jellegü információk. Az a feltevésünk, miszerint a vad fajok hordozhatnak rezisztenciát, részben be is igazolódott, mivel a $P c c$-val szemben rezisztensnek ítélt 77365/103, valamint a mérsékelten rezisztens 77399/514 felmenői között szerepel vad Solanum faj, mégpedig a Solanum chacoense.

A fertőzött növényi szövetekből történő visszaizolálással azért egészítettük ki a hajtásfertőzés módszerét, mert kiváncsiak voltunk arra, hogy a baktériumszámlálással alátudjuk-e támasztani a hajtásfertőzéskor kapott eredményeinket, azaz korrelációt mutat-e a tünetek súlyossága az emelkedett baktérium sejtszámmal.

A fertőzést követő harmadik nap végzett visszaizoláláskor a szúrás környéki mintákból tenyésztettük ki a legtöbb baktériumsejtet mindkét baktériumfajnál. A fajták közötti eltérések párhuzamba állíthatók a hajtásfertőzéskor kapott eredményekkel. Az Pcc visszaizolálásakor a többi fajtához képest magasabb baktérium sejtszámot kaptunk az erősen fogékony 98/91 esetében, ami teljesen megfelelt a hajtásfertőződés eredményének. Az $D d$ esetében pedig a 'Boró' és a 136/92 klónból vett mintákból izoláltuk vissza a legtöbb baktériumsejtet, míg a legkevesebbet a 34/85 klónból.

A fertőzést követő hetedik napos visszaizolálásnál a szúrás helyén továbbra is magas baktérium sejtszámokat kaptunk a másik két visszaizolálási helyhez viszonyítva, viszont a szúrás alatti mintákban is jelentősen megnőtt a sejtszám, ami arra enged következtetni, hogy a szárban lefelé terjed a fertőzés. Az eredményeinkből úgy tünik, hogy az $D d$ szaporodása és terjedése lassabb a szárban, mint a $P c c$-é. Ez lehet az oka annak is, hogy miért nem okozott az $D d$ olyan erősségü tüneteket az in vitro burgonyahajtásokon, mint a $P c c$.

Egy másik módszer, amit kidolgoztunk a burgonyafajták fogékonyságának tesztelésére az az in vitro gumófertőzés módszere volt. Ugyanazon megfigyelési időpontokat alkalmaztuk, mint az in vitro hajtásfertőzés esetében.

A Pcc-val történt fertőzések során az utolsó megfigyelési időpontban (fertőzést követő hetedik nap) kapott eredmények alapján csoportosítottuk a klónokat. Ebben az esetben három fogékonysági kategóriát tudtunk meghatározni (rezisztens, mérsékelten fogékony és erősen fogékony). A 'Rachel' mindhárom megfigyelési időpontban ellenállónak bizonyult. A „kakukktojás” a 98/91 volt, mivel az első két megfigyelés során nagyon jól reagált a biotikus stresszre, de az utolsó megfigyelési időpontban a fertőzés elhatalmasodott a gumókon. A mikrogumók háromnegyede teljesen elrohadt a fertőzést követő egy hét után. Az így kapott végeredmény teljes összhangban volt az in vitro növényfertőzés eredményével. 
Az $D d$-val történt fertőzésekre adott válaszok alapján jobban elváltak a fajták egymástól, négy fogékonysági csoportot tudtunk kialakítani (rezisztens, mérsékelten rezisztens, mérsékelten fogékony és erősen fogékony).

A $P c c$-val összehasonlítva az ott rezisztensnek ítélt 'Rachel' a $D d$-val szemben mérsékelten fogékony volt, míg a 98/91 erős fogékonyságot mutatott a $P c c$-val szemben, itt viszont szintén a közepes fogékonyságúak csoportjába soroltuk. Az $D d$-val szemben rezisztens 77399/514 és a legfogékonyabb 'Boró’ a $P c c$-val szemben közepes fogékonysággal bírt.

Az in vitro hajtásfertőzéssel összehasonlítva elmondható, hogy a 'Boró' gumója és hajtása is erösen fogékonynak bizonyult az $D d$-val szemben. A 136/92 gumója mérsékelten rezisztens, míg a hajtása erősen fogékony volt. A 'Cleopátra' gumója mérsékelten fogékony, míg a hajtás érzékenységét mérsékelten rezisztensnek ítéltük. A 'Desiree', a 98/91 és a 77365/103 hajtása és gumója is hasonlóan reagált a fertőzésre, mindkét esetben mérsékelten fogékonyak voltak.

Az eredményeink alapján láthatjuk, hogy egy növény különböző részei eltérő módon reagálhat a fertőzésekre. Ezért fordulhat elő, hogy egy fajta gumója fogékony, míg a hajtásrésze ellenállóbbnak bizonyul vagy fordítva egy adott fertőzésre.

A teljesség kedvéért teszteltünk egy a szakirodalomban már leírt módszert is, ez volt az üvegházi gumófertőzés módszere (Vlaslov és Pereverzev, 1989). Eredményeink alapján ezzel a módszerrel tudtunk a legtöbb fogékonysági csoportot létrehozni mind a $P c c$-val, mind a $D d$-val végzett fertőzéseket követően (rezisztens, mérsékelten rezisztens, mérsékelten fogékony, fogékony és erősen fogékony).

Az üvegházi gumók fertőzésének módszerével vizsgálva a fajtákat megállapíthatjuk, hogy mindkét baktériummal szemben a legellenállóbb 77399/514 , 136/92 és 'Boró' közül egyedül az $77399 / 514$ volt az, mely az in vitro gumófertőzéskor is ellenállóbbnak bizonyult, bár Pcc-val szemben mérsékelten fogékony csoportba soroltuk, de ott csak egyetlen közepes fogékonyságú kategóriát tudtunk megállapítani. Ez volt az a klón, mely az in vitro növényfertőzés során is közepes rezisztenciát mutatott mindkét baktériumfajjal szemben.

Összehasonlítva a módszerek végeredményeit elmondhatjuk, hogy vannak közöttük eltérések és hasonlóságok. Attól függően, hogy mik a terveink a termesztett burgonyával, az dönti el, hogy melyik módszer eredményeit vesszük figyelembe. Mivel a betegség a száron jelenik meg először, ha ott ellenállóbb egy fajta, akkor valószínü, hogy a gumófertőzés nem is jön létre. Ezért a három módszer közül az in vitro hajtásfertőzés módszere volt az, amit leginkább alkalmasnak találtunk arra, hogy egy fajta fogékonyságát leteszteljük. Ezzel a módszerrel teljesen sterilen dolgozva, ki lehet zárni mindenféle másodlagosan rothadást előidéző baktériumot. In vitro növények esetében zsenge, zöld hajtásokról van szó, melyekben a baktériumok gyors szaporodásra képesek. A kémcsövekben lévő páratartalom, hőmérséklet szintén ideálisak a 
fertőzés kialakulásához. Ezen „,ideális” feltételek a másik két módszernél nem adottak. Viszont, ha célunk az, hogy hosszabb távra szeretnénk raktározni a burgonyát, akkor a gumóellenállósága a fontosabb.

Az almafajták fogékonyságának/rezisztenciájának fokozatait a növények hajtásának, ill. virágának segítségével szokták meghatározni. Virágfertőzéseket nem végeztünk, kizárólag in vitro hajtások fertőzésével teszteltük a fajtákat.

Magyarországon mesterséges fertőzést szabadföldi körülmények között nem lehet végrehajtani, mivel karantén kórokozóról van szó. Továbbá a spontán fertőződésből származó adatok sem megbízhatóak a növényállomány egyenlőtlen fertőződése miatt. Ezért tartottuk szükségesnek az inokulációs kísérletek elvégzését in vitro körülmények között.

A fertőzési indexek alapján a következő fogékonysági csoportokat határoztuk meg: rezisztens, mérsékelten rezisztens, mérsékelten fogékony és erősen fogékony.

Az almafajták fogékonyságával foglalkozó vizsgálatok (Sobiczewski et al., 1997; Fischer et al., 2004; Tóth et al., 2005) eredményei szerint az 'Idared' erősen fogékony a tüzelhalás kórokozójával szemben. A mi eredményeink szerint egy közepes fogékonyság bizonyítható.

A Wisconsin Egyetemen McManus és Heimann (1997) által végzett vizsgálataik szerint a 'Freedom' rezisztensnek, míg a 'Tenroy', 'Idared' és 'Jonagold' fajtákat erősen fogékonynak találták. Ezt az eredményt a mi vizsgálataink részben alátámasztják. Eltérést az 'Idared' és 'Jonagold' fajtáknál tapasztaltunk, mely a mi vizsgálatainkban közepes fogékonyságot mutattak.

A 'Hesztia' egyike a Tóth Magdolna (2012) által nemesített, államilag elismert multirezisztens fajtának, mely a mi vizsgálatainkban a tüzelhalással szemben mérsékelten rezisztensnek mutatkozott.

A mikroszaporított és a kifejlett növények eltérő fogékonysága valószínűleg a hajtások eltérő szöveti szerkezetére vezethető vissza. Az in vitro növények hisztológiai jellemzői nem egyeznek meg a szabadföldön vagy üvegházban nevelt növényekével. Általában az in vitro növények levélszövetei 50\%-kal vékonyabbak, az epidermiszen kevésbé fejlett a viaszréteg (Ganeva et al., 2009). A sztómák az epidermiszből gyakran kiemelkednek, nyitottak és sürübben helyezkednek el. A levelek keresztmetszetét összehasonlítva az in vivo levelekben jól elkülöníthető az oszlopos és a szivacsos parenchima, míg az in vitro levelek oszlopos parenchimája általában egy sejtsoros és a szivacsos parenchima sokkal tömörebb, kevesebb sejtközötti járatot tartalmaz (JámborBenczúr et al., 2001). A szár szöveti felépítése szintén eltérő, amit Kiss et al. (1997) tanulmányoztak hortenzián. Megállapították, hogy kifejlett növényeknél a szállítónyalábok jól elkülöníthetőek, a központi henger jól fejlett. A mikroszaporított növényeknél a központi henger jóval fejletlenebb, a szállítószövetek aránya nagyobb a szár keresztmetszetében és a bélszövetek viszonylag fejletlenebbek, mint az in vivo növényekben. 
Tóth et al. (2013c) szerint a rezisztencianemesítésben a szelekció költséghatékonyság szerint is a legelőnyösebb módja az lehet, ha előbb a virágok fogékonysága alapján végzünk szelekciót, s utána M.9. alanyú oltványok hajtásainak fertőzésével értékeljük a hibridek tüzelhalással szembeni ellenállóságát.

A különböző fajok in vitro hajtásaiban a fertőzés hatására létrejövő biokémiai változásokról szóló szakirodalom elég szórványos. Az előkísérletek alapján megállapítható, hogy a módszer alkalmas a biotikus stresszhatás nyomon követésére. Ahhoz, hogy egzakt eredményeket kapjunk, célszerü lenne az eddigi hasonló jellegü kísérletek (Honty, 2010; Szecskó, 2004) alapján a min. $300 \mathrm{mg}$ minta biztosítása.

A peroxidáz enzimaktivitás vizsgálatok során kiderült, hogy a rezisztens fajták kiindulási POD szintje magasabb, mint a fogékony fajtáké. A Pcc fertőzés hatására bekövetkező változásokról megállapítható, hogy a fertőzés utáni hatodik óráig csökken a POD aktivitás, majd emelkedni kezd. A rezisztens 77365/103 klónban POD szintje a kiindulási értékhez képest alig változik a fertőzést követő 24 óra múlva, míg az erősen fogékony 98/91 klónban duplájára nő a POD aktivitás. A fertőzés hatására bekövetkező változás nem tartós, kiegyenlítődik.

$D d$ fertőzés hatására a kontrollhoz képest, az eltérő fogékonyságú klónok eltérően reagálnak. $\mathrm{Az}$ erősen fogékony 'Boró' fajtában emelkedő tendenciát mutat a POD aktivitás, addig a rezisztens 34/85 klónban és a közepes fogékonyságú 'Réka' fajtában van egy csökkenő szakasz, de a fertőzést követő 24 órával kiegyenlítődik a változás. A kontrollhoz képest minden esetben emelkedik a POD aktivitás, az erősen fogékony fajtában nagyobb mértékü ez a változás, mint a rezisztens klónban. Ez hasonlóságot mutat az Pcc-nál tapasztaltakkal.

$E a$ fertőzés hatására a kontrollhoz képest szintén változás történik, amely a fertőzést követő 24. órára tehető. A rezisztens 'Freedom' fajtában mindez nem tartós, mert a fertőzés után 72 órával kiegyenlítődik. A mérsékelten fogékony 'Húsvéti rozmaring' és erősen fogékony ‘Tenroy' fajtákban viszont egy tartós változást tapasztaltunk, a POD aktivitása folyamatosan nőtt a megfigyelés során. Ezek a változások hasonlóak az Ea-nál tapasztaltakkal.

Honty (2010) hasonló eredményeket kapott kifejlett növények (körte) vizsgálatánál. Vizsgálataiban az ellenálló körtefajta kontrolljában kétszerese volt a peroxidáz enzimaktivitás, mint a fogékony fajtában. A fertőzés hatására kb. 50\%-kal nőtt a POD aktivitás a fogékony fajtában, míg az ellenálló fajtában először csökkent, majd később már nem változott.

Az in vitro hajtások szénhidrát frakcióinak elemzése alapján a jól detektálható cukrok közül burgonyánál a glükózt és a fruktózt tudtuk kimutatni, míg almánál glükózt, fruktózt, szacharózt és a D-szorbitolt is. Ezek közül burgonyánál mindkét baktériumfaj esetében a fruktóz változása volt a legjellemzőbb, ezzel a szénhidráttal lehet leginkább jellemezni a fogékony és rezisztens 
gazdaválaszt. Alma esetében ez a szénhidrát a szacharóz volt, itt tudtunk a legnagyobb különbségeket megfigyelni az eltérő fogékonyságú fajták között.

A burgonya és alma mikroszaporított növényeinek biokémiai vizsgálata során tapasztalt azonosságokat és eltéréseket a következőképpen foglalnám össze:

- A kezdeti POD értékek hasonlóan alakultak mindkét növényfaj esetében. Legmagasabb POD aktivitás a rezisztens genotípusokban volt, legalacsonyabb az erősen fogékonyakban.

- Biotikus stressz hatására mindenhol tapasztaltunk változást; a kiindulási POD értékekhez képest egy csökkenés következik be, mely az alma mindhárom fogékonyságú fajtánál a fertőzést követő 24 óra után a legkevesebb. Burgonyánál ez az érték három és hat óra közé tehető.

- A POD értékekben tapasztalt csökkenést minden esetben egy emelkedés követi akár lágyrothadást, akár hajtásszáradást előidéző baktériumok okozta stresszről legyen is szó.

- A szénhidrátok közül a kiindulási glükóztartalmat megvizsgálva elmondható, hogy mind az alma, mind a burgonya esetén a legmagasabb értékeket az erősen fogékony genotípusokban tapasztaltunk.

- A fertőzések hatására az eltérő fogékonyságú burgonya genotípusokban a glükóz- és fruktóztartalom változása ugyanazt a tendenciát követi, a fertőzést követő hatodik órában van a minimuma ezeknek a szénhidrátoknak, majd ezt követően egy folyamatosan emelkedést tapasztalhatunk. Alma esetében viszont a rezisztens és erősen fogékony fajták nem azonos módon reagálnak a fertőzésre egyik vizsgált szénhidrát esetében sem.

Ezekből az eredményekből arra következtethetünk, hogy a növények védekezése a kórokozókkal szemben egy általános mechanizmus szerint történik. A gazdanövény azonos módon reagál a különböző baktériumok fertőzésére, azaz a kórfolyamatok nem függnek a betegségtípusoktól. A biotikus stressz hatására bekövetkező biokémiai folyamatok azonosak mind az in vitro, mind a kifejlett növényekben. 


\section{7. ÖSSZEFOGLALÁS}

A klimatikus viszonyok változásának köszönhetően számolnunk kell arra, hogy újabb és újabb stresszhatások érik kultúrnövényeinket, melyekhez alkalmazkodniuk kell. Az utóbbi időben a szélsőséges időjárási körülmények mellett egyre jelentősebb stresszfaktor a járványosan fellépő kórokozók (kártevők) előfordulása. Fontos feladat hárul a növénynemesítőkre, hogy olyan új növényfajtákat nemesítsenek, melyek képesek alkalmazkodni ehhez a változó környezethez megfelelő termésbiztonság elérése mellett.

Dolgozatomban a Nyírségi tájkörzet két kiemelkedő jelentőségü növényével, a burgonyával és az almával foglalkoztam. A burgonyánál a Pectobacterium carotovorum subsp. carotovorum (Syn. Erwinia carotovora subsp. carotovora) és a Dickeya dadantii (Syn. Erwinia chrysanthemi) okoz ún. lágyrothadást, míg az Erwinia amylovora az almánál hajtáselhalást okoz.

Mindhárom kórokozóval szembeni védekezés lehetőségei korlátozottak. Burgonya esetében a kórokozók a paraszemölcsökben vagy az edénynyaláb rendszerben helyezkednek el, ezért a növényvédőszeres védekezés nem megoldható. Alma esetében a leghatásosabb növényvédőszer a sztereptomicin - használatának betiltásával a védekezési lehetőségek köre csökkent. Költségés környezetkímélő lehetőség lenne mindkét növényfaj esetében a rezisztens fajták köztermesztésben való alkalmazása. A Debreceni Egyetem ATK Nyíregyházi Kutatóintézete évtizedek óta foglalkozik burgonyanemesítéssel. A nemesítői munkánk különböző vad Solanum fajok használatán alapul. Irodalmi adatok alapján feltételezhetjük, hogy alapanyagaink, illetve klónjaink között, a Pectobacterium és a Dickeya fajokkal szembeni rezisztenciát/toleranciát hordozók is szerepelhetnek. A nyíregyházi burgonyafajtákat és nemesítési klónokat eddig ilyen irányú vizsgálatnak még nem vetették alá. Az almafajták Ea-val szembeni ellenállóságáról több irodalmi adat áll rendelkezésünkre, viszont a mikroszaporított növények fogékonyságáról már lényegesen kevesebb információnk van.

A fentiek tükrében célul tüztük ki, hogy burgonyafajták/klónok és almafajták fogékonyságát/ellenállóságát leteszteljük mikroszaporított növényeken. Ezek a növények az év bármely időszakában elöállíthatók. In vitro körülmények között évjárathatással nem kell számolni, a mesterséges fertőzések standard körülmények között hajthatók végre. Mivel az Ea karantén kórokozó, ezért szabadföldi kísérletek végrehajtása nem lehetséges, de az in vitro tenyészeteket tökéletesen alkalmasak zárlati kórokozók tesztelésére is, mivel steril körülmények között, biztonságosan folynak a fertőzések és a megfigyelések is.

Tizenhárom burgonya genotípus, valamint hét almafajta fogékonyságát vizsgáltuk a különböző baktériumfajokkal szemben. Mindhárom kórokozóról elmondható, hogy csak a friss, 
zöld hajtásban képes szaporodni és terjedni. A cél megvalósítása érdekében burgonyánál kidolgoztunk két, új és gyors in vitro fertőzési eljárást: egy hajtás és egy gumófertőzési eljárást. Ezek eredményeit egy, a szakirodalomban már leírt üvegházi gumófertőzési módszer eredményeivel egészítettük ki.

$\mathrm{Az}$ in vitro hajtásfertőzés módszerénél először megállapítottuk a vizuális tüneteket. Megállapítottuk, hogy mindkét burgonyát károsító baktériumfaj hasonló tüneteket okozott. A fajták és klónok fogékonysága azonban eltérő volt. A Pcc-val szemben perspektivikusnak találtuk a 77365/103 klónt és a 'Rachel' fajtát, míg az $D d$-val szemben a 34/85 klónt. Az in vitro gumófertőzés módszerénél az $P c c$-val szemben rezisztensnek a 'Rachel' fajtát, míg az $D d$-val szemben rezisztensnek a 77399/514 klónt tekintettük.

Az üvegházi gumófertőzés módszere (Vlasov és Pereverzev, 1989) szerint rezisztensnek adódott az $P c c$-val szemben a 136/92, a 77399/514, 'Boró' és 'Cleopátra'. Az Dd-val szemben ellenállónak bizonyult a 77399/514. Megállapítottuk, hogy a három módszer közül az in vitro hajtásfertőzés módszere a legalkalmasabb arra, hogy egy fajta fogékonyságát teszteljük, mivel a kórokozó szántóföldön a talajközeli szárrészt támadja meg először és innen fertőződik meg a gumó is. Ha a szár nem beteg, akkor a gumó sem lesz az. Eredményeink fontos információkat szolgáltathatnak a burgonyanemesítők számára, mely segíthet a hagyományos nemesítési időt jelentősen lerövidíteni.

Hevesi et al., (2000) által kidolgozott módszerrel teszteltük az in vitro almanövények fogékonyságát a tủzelhalás kórokozójával szemben. Vizsgálatainkban rezisztens volt a 'Red Fuji' és a 'Freedom'; mérsékelten rezisztens a 'Hesztia', mérsékelten fogékony az 'Idared', 'Húsvéti rozmaring' és a 'Jonagold', valamint erősen fogékony a 'Tenroy' (Royal Gala). A mikroszaporított és a kifejlett növények eltérő fogékonysága az eltérő szöveti szerkezetre vezethető vissza.

A fertőzési kísérletek eredményeit a fertőzött növényi szövetekből történő baktérium sejtszám meghatározásával egészítettük ki. A hajtásfertőzés eredményeit teljes mértékben alátámasztották a visszaizoláláskor kapott eredmények. Az adatokból azt a következtetést is levonhattuk, hogy a fertőzés a szárban lefelé terjed.

Kutatásaink során a részletes kórfolyamaton túl kíváncsiak voltunk a fertőzés hatására bekövetkezö biokémiai változásokra is. A stressz hatására képződő reaktív oxigén gyököket a növény antioxidáns védelmi rendszere hatástalanítja. Mikroszaporított növényröl kevés információ állt rendelkezésünkre, hogy ezen redszer enzimatikus és nem enzimatikus részét képező vegyületei hogyan változnak a fertőzés hatására. Arra szerettünk volna válasz kapni, hogy a két különböző baktériumos betegség (lágyrothadás, hajtáselhalás) folyamatát azonos, vagy eltérö biokémiai folyamatok kísérik-e. Vizsgáltuk a fogékony, a mérsékelten fogékony és a 
rezisztens fajták in vitro hajtásaiban a peroxidáz enzimaktivitás és a szénhidrátfrakciók változásait a fertőzés hatására.

Megállapítottuk, hogy mind a burgonyánál, mind az almánál a peroxidáz enzimaktivitás változása jó markernek tekinthető a fogékony és rezisztens gazdaválasz nyomon követésére. A kiindulási POD aktivitás minden esetben magasabb volt a rezisztens fajtákban, mint a fogékonyakban. A stressz hatására a fogékony fajták érzékenyebben reagáltak, a megfigyelés során a kontrollhoz képest minden esetben megnőtt a fertőzött szövetek POD aktivitása. A rezisztens fajtákban egyfajta kiegyenlítődés volt tapasztalható, az utolsó megfigyelési időpontokban a kiindulási (kontroll) értékekhez közeli POD aktivitásokat mértünk.

A szénhidrátok közül burgonyánál a fruktóz változása jellemezte jól a kórfolyamatot, almánál pedig a szacharóz. Pcc fertőzés hatására a fruktóztartalom változása ugyanazt a tendenciát követte mind a rezisztens, mind a fogékony fajta esetében. A fertőzés hatására a fruktóztartalom elöször csökkenésnek indult, majd a fertőzést követő 24. órára kiegyenlítődött a változás. $D d$-val történő fertőzés hatására viszont egy folyamatos fruktózemelkedést tapasztaltunk a rezisztens és a fogékony fajtában is. Ea-val végzett fertőzések során a szacharóztartalom változásában ellenkező tendencia érvényesült az eltérő fogékonyságú fajtákban. A rezisztens fajtában a szacharóztartalom a fertőzést követő 24. órában éri el a maximumát, de a fertőzést követő 120. órára a fruktózszint visszaáll a kiindulási értékre. A fogékony fajtában a fertőzést követő 24 órában a fruktóztartalom folyamatosan csökkent, majd emelkedő tendenciát mutat és a fertőzést követő 120. órára eléri a kiindulási értéket. 


\section{SUMMARY}

It is expected that crops will suffer from newer and newer stress, and they have to adapt to the new conditions caused by the change of climate. Recently, occurrence of epidemic pathogens and pests become an increasingly important stress factor beside the extreme weather conditions. Development of new cultivars, which able to adapt to the changing environment and can be grown with proper crop safety, is an important task falls to the plant breeders.

Results obtained in our research work with potato and apple crops - both have a great importance in the Nyírség region - are presented in this dissertation.

In the case of potatoes infection by the Pectobacterium carotovorum subsp. carotovorum (Syn. Erwinia carotovora subsp. carotovora) and the Dickeya dadantii (Syn. Erwinia chrysanthemi) cause so-called soft-rot, while in the case of apples infection by the Erwinia amylovora result in shoot necrosis.

Protection options against these pathogens are limited. In the infected potatoes these bacteria are in the vascular system or lenticels, thus chemical protection is not effective method. Similarly, the chemical protection in apple plantation against to $E a$ is very difficult because the most effective agent (streptomicyn) has been banned.

Development of resistant cultivars/varieties and utilization of them in agriculture would be a cost-effective and environment friendly solution. Our Institute (University of Debrecen Centre for Agricultural Sciences Research Institute in Nyíregyháza) has been engaged in potato breeding for decades. Our breeding work is based on the utilization of wild Solanum species, thus it can be supposed that our breeding material includes lines and clones, which are tolerant or resistant against to Pectobacterium and Dickeya species, however prior to our study our breeding clones and cultivars have not been tested for their tolerance.

More information available about sensitivity of apple cultivars to $E a$, however, there is much less information about responsibility of in vitro apple shoots produced by microprogation. Differences found in the sensitivity of in vivo and in vitro plantlets (shoots) maybe due to the differences in their tissue structures.

The aim of our research work was to test the sensitivity/tolerance properties of micropropagated potato cultivars/clones and apple cultivars. In vitro plantlets can be produced in any season of the year, there is not any "crop-year-effect", and infection can be performed under standard and controlled conditions. Since $E a$ is a quarantine bacterium, field infection experiments are not permitted, but in vitro cultures are suitable for test of quarantine pathogens, because experiments (infections and observations) are securely conducted under sterile and 
controlled conditions. In our experiments sensitivity of thirteen potato breeding clones and cultivars and seven apple scions against to bacteria was tested. Each bacterium species tested can proliferate and spread only in fresh and green shoots.

In order to realize in our aims we have developed new and fast in vitro methods for infection of shoots and tubers, respectively. Addition to these methods a tuber-infection method, which were made on tubers grown in green-house, was also applied, which has previously been reported in literature (Vlasov and Pereverzev, 1989).

Symptoms were detected visually on infected in vitro shoots and we found that both bacteria species caused similar symptoms on potato. Sensitivity of cultivars and clones were different: 77365/103 clone and 'Rachel' cultivar showed an adequate resistance against to Pcc, while $34 / 85$ clone proved to be resistant against to $D d$, thus they can be considered as perspective genotypes.

The 'Rachel' cultivar was also proven to be resistant against to $P c c$ in experiments in which in vitro tubers were infected, but only 77399/514 clones showed resistance against to $D d$.

In the experiments, in which green-house grown tubers were infected, genotypes showing resistance against to Pcc were the 136/92 and 77399/514 clones, and 'Boró' and 'Cleopátra' cultivars, while only $77399 / 514$ clone was proven to be resistant against to $D d$.

Infection of in vitro shoots was found to be the most suitable method to detect the sensitivity of genotypes, and to serve information for potato breeders, which can help the traditional breeding work by reduction of the period required for development of new cultivar.

We have also tested the sensitivity of in vitro apple shoots against to the fire blight applying method developed by Hevesi et al. (2000). In our study 'Red Fuji' and 'Freedom' scions were proven to be resistant.

The number of bacterial cells isolated from infected tissue was also determined. These results completely confirmed our previous results obtained from experiments with infected shoots. We found, that the infection spread downward in the stem.

Biochemical changes induced by infection were also studied. Reactive oxygen radicals induced by stress will be deactivated by the antioxidant defence system of plant. There is very little available information about response of micropropagated plantlets considering changes in these molecules included in the enzymatic and non-enzymatic part of this system when infection occurs.

We would have liked to clarify that the process of two different bacterial diseases (soft-rot and shoot-necrosis) are accompanied by the same or different biochemical processes. Therefore, activity of peroxidise enzyme and changes of carbohydrates induced by infection were also examined in in vitro shoots of sensitive, moderate sensitive and resistant cultivars. We found, 
that the changes in POD activity enzyme could be suitable marker for follow-up in responses of sensitive and resistant hosts in the case of both crops (apple and potato). The initial POD activity was always at higher levels in the resistant genotypes compared to the sensitive ones. However, sensitive genotypes were more responsible: the POD activity increased in infected tissues in each case compared to the control. Some kind of equalization could be observed in the resistant genotypes: levels of POD activity observed at the last observation time were similar to the ones observed at initiation (control).

Among carbohydrates changes in fructose and saccharose levels characterised properly the disease process in potato and apple, respectively.

Changes in fructose content induced by $P c c$ infection showed the same tendency in both the resistant and the sensitive genotypes. Immediately after infection the fructose content decreased but after 24 hours its level was equalised. However, when infection was made by $D d$, the fructose content increased steadily in both the resistant and sensitive genotypes.

In contrast, changes in saccharose content was different in the genotypes with different sensitivity when infection occurred by Ea. Accordingly, the saccharose content reached a maximum at 24 hours after infection, but at 120 hours after infection the saccharose content decreased down to the initial level in the resistant genotypes. In contrast, in the sensitive genotypes the saccharose content decreased steadily during the 24 hours period after infection but later it increased and reached the initial level at 120 hours after infection. 


\section{M1 IRODALOMJEGYZÉK}

1. AFEK U., ORENSTEIN J. (2002): Disinfecting potato tubers using steam treatments. Canadian Journal of Plant Pathology, 24: 36-39. p.

2. AL-ARABI K. F. (2002): Novel antagonistic bacteria as prospective agents for the biocontrol of some plant bacterial diseases. Doktori értekezés, Budapesti Corvinus Egyetem.

3. ALLAN A. C., FLUHR R. (1997): Two distinct sources of elicited reactive oxygen species in tobacco epidermal cells. The Plant Cell, 9: 1559-1572. p. DOI: 10.1105/tpc.9.9.1559

4. ALLEFS S. J. H. M., VAN DOOIJEWEERT W., DE JONG E. R., PRUMMEL W., HOOGENDOORN C. (1995): The role of the seed tuber in determining partial resistance to potato blackleg caused by Erwinia spp. European Journal of Plant Pathology, 101: 189-199. p. DOI: 10.1007/BF01874765

5. ANILKUMAR T. B., CHAKRAVARTI B. P. (1970): Factors affecting survival of Erwinia carotovora, causal organism of stalk rot of maize, in soil. Acta Phytopathologica Academiae Scientarium Hungaricae, 5: 333-340. p.

6. APEL K., HIRT H. (2004): Reactive oxygen species: metabolism, oxidative stress, and signal transduction. Annual Review of Plant Biology, 55: 373-399. p. DOI: 10.1146/annurev.arplant.55.031903.141701

7. ASADA K. (1992): Ascorbate peroxidase - a hydrogen peroxide-scavenging enzyme in plants. Physiologia Plantarum, 85: 235-241.p. DOI: 10.1111/j.1399-3054.tb.04728.x

8. AUSTIN S., LOJKOWSKA E., EHLENFELDT M. K., KELMAN A., HELGESON J. P. (1988): Fertile interspecific somatic hybrids of Solanum: a novel source of resistance to Erwinia soft rot. Phytopathology, 78: 1216-1220. p.

9. BAHMANI R., KARAMI O., GHOLAMI M. (2009): Influence of Carbon Sources and Their Concentrations on Rooting and Hyperhydricity of Apple Rootstock MM.106. World Applied Sciences Journal, 6 (11): 1513-1517. p.

10. BAIN R. A., PÉROMBELON M. C. M. (1988): Methods of testing potato cultivars for resistance to soft rot of tubers caused by Pectobacterium carotovorum subsp. atroseptica. Plant Pathology, 37: 431-437. p.

11. BAKER C. J., ORLANDI E. W. (1995): Active oxygen in plant pathogenesis. Annual Review of Phytopathology, 33: 299-321.p. DOI: 10.1146/annurev.py.33.090195.001503

12. BARNA B. (1995): Betegség- és abiotikus stressztoleráns növények előállítása a juvenilitás és az antioxidáns kapacitás fokozásával. Növénytermelés, 44: 561-567. p.

13. BARNA B., FODOR J., POGÁNY M., KIRÁLY Z. (2003): Role of reactive oxygen species and antioxidants in plant disease resistance. Pest Management Science, 59: 459-464. p. DOI: 10.1002/ps.706

14. BARTZ J. (1999): Suppression of bacterial soft rot in potato tubers by application of kasugamycin. American Journal of Potato Research, 76: 127-136. p. DOI: 10.1007/BF02853577

15. BARTZ J., KELMAN A. (1985): Effect of air-drying on soft rot potential of potato tubers inoculated by immersion in suspensions of Erwinia carotovora. Phytopathology, 69: 128-131. p.

16. BARTZ J., KELMAN A. (1986): Reducing the potential for bacterial soft rot in potato tubers by chemical treatments and drying. American Journal of Potato Research, 63: 481-493. p.

17. BAUMGARTNER I. O., LEUMANN L. R., FREY M., JOOS M., VOEGELE R. T., KELLERHALS M. (2012): Breeding apples to withstand infection pressure by fire blight and other diseases. 15th International Conference on Organic Fruit-Growing: Proceedings to the Conference, February 20- 22, 2012 at Hohenheim/Germany. Weinsberg: FOEKO, 14-21. p.

18. BDLIYA B., HARUNA H. (2007): Efficacy of solar heat in the control of bacterial soft rot of potato tubers caused by Erwinia carotovora ssp. carotovora. Journal of Plant Protection Research, 47: 11-18. p.

19. BERGER F., ZELLER W. (1994): Resistenz von Apfel- und Birnensorten gegen Feuerbrand nach Blüteninfektion. Obstbau, 8: 403-404. p.

20. BESTWICK C. S., BROWN I. R., BENNETT M. H. R., MANSFIELD J. W. (1997): Localization of hydrogen peroxide accumulation during the hypersensitive reaction of lettuce cells to Pseudomonas syringae pv. phaseolicola. The Plant Cell, 9: 209-221. p.

21. BOLAR J. P., NORELLI J. L., ALDWINCKLE H. S., HANKE V. (1998): An efficient method for rooting and acclimation of micropropagated apple cultivars. HortScience, 33 (7): 1251-1252. p.

22. BONDE R., DE SOUZA P. (1954): Studies on the control of potato bacterial seed-piece decay and blackleg with antibiotics. American Journal of Potato Research, 31:311-316. p.

23. BÖSZÖRMÉNYI E., ÉRSEK T., FODOR A., FÖLDES L. SZ., HEVESI M., HOGAN J. S., KATONA, Z., KLEIN M.G., KORMÁNY A., PEKÁR SZ., SZENTIRMAI A., SZTARICSKAI F., TAYLOR R. A. J. (2009): Isolation and activity of Xerorabdus antimicrobial compounds against the plant pathogens Erwinia amylovora and Phytophtora nicotianae. Journal of Applied Microbiology, 107: 746-759. p. DOI: 10.1111/j.1365-2672.2009.04249.x

24. BUBÁN T., BESZEDA E., DORGAI L., FÖLDES L., HUDÁK I., DOBRÁNSZKI J., HEVESI M. (2006): Erwinia amylovora infection of flowers and shoots in apple trees treated with Prohexadione-Ca. Acta Horticulturae, 704: 271-276. p. 
25. BURKHOLDER W. H., MCFADDEN L.A., DIMOCK A. W. (1953): A bacterial blight of chrysanthemum. Phytopathology 43: 522-526. p.

26. BURRILL A. C. (1882): The bacteria: an account of their nature and effects, together with a systematic description of the species. III. Indus. University Annual Reports, 11: 93-157 p.

27. CADENAS E. (1989): Biochemistry of oxygen-toxicity. Annual Review of Biochemistry, 58: 79-110. p. DOI: 10.1146/annurev.bi.58.07019.000455

28. CARPUTO D., CARDI T., SPEGGIORIN M., ZOINA A., FRUSCIANTE L. (1997): Resistance to blackleg and tuber soft rot in sexual and somatic interspecific hybrids with different genetic background. American Journal of Potato Research, 74: 161-172. p. DOI: 10.1007/BF02851595

29. ClADERA-OliverA F., CARON G. R., MOTTA A. S., SOUTO A. A., BRANDELli A. (2006): Bacteriocin-like substance inhibits potato soft rot caused by Pectobacterium carotovorum. Canadian Journal of Microbiology, 52: 533-539. p. DOI: http://dx.doi.org/10.1139/w05-159

30. COMPANT S., DUFFY B., NOWAK J., CLEMENT C., BARKA E. A. (2005): Use of plant growthpromoting bacteria for biocontrol of plant diseases: principles, mechanisms of action, and future prospects. Applied and Environmental Microbiology, 71: 4951-4959. p. DOI: 10.1128/AEM.71.9.4951-4959.2005

31. CRONIN D., MOENNE-LOCCOZ Y., FENTON A., DUNNE C., DOWLING D. N., O’GARA F. (1997): Ecological interaction of a biocontrol Pseudomonas fluorescens strain producing 2,4diacetylphloroglucinol with the soft rot potato pathogen Pectobacterium carotovorum subsp. atroseptica. FEMS Microbiology Ecology, 23: 95-106. p. DOI: 10.1111/j.1574-6941.1997.tb00394.x

32. CZAJKOWSKI R., DE BOER W. J., VELVIS H., VAN DER WOLF J. (2010): Systemic colonization of potato plants by a soilborne, green fluorescent protein-tagged strain of Dickeya sp. biovar 3. Phytopathology, 100: 134-142. p. DOI: 10.1094/PHYTO-100-2-0134

33. DASHWOOD E., BURNETT E., PÉROMBELON M. (1991): Effect of a continuous hot water treatment of potato tubers on seed-borne fungal pathogens. Potato Research, 34: 71-78. p. DOI: 10.1007/BF0235097

34. DE HAAN E. G., DEKKER-NOOREN T. C. E. M., VAN DEN BOVENKAMP G. W., SPEKSNIJDER A. G. C. L., VAN DER ZOUWEN P. S., VAN DER WOLF J. M. (2008): Pectobacterium carotovorum subsp. carotovorum can cause potato blackleg in temperate climates. European Journal of Plant Pathology,122: 561-569. p. DOI: 10.1007/s10658-008-9325-y

35. DIAZ-VIVANCOS P., RUBIO M., MESONERO V., PERIAGO P. M., ROS BARCELÓ A., MARTÍNEZGÓMEZ P., HERNANDEZ J. A. (2006): The apoplastic antioxidant system in Prunus: response to longterm plum pox virus infection. Journal of Experimental Botany, 57: 3813-3824. p. DOI: $10.1093 / \mathrm{jxb} / \mathrm{erl138}$

36. DJEBALI N. MHADHBI H., JACQUET C., HUGUET T., AOUANI M. E. (2007): Involvement of hydrogen peroxide, peroxidase and superoxide dismutase in response of Medicago truncatula lines differing in susceptibility to Phoma medicaginis infection. Journal of Phythopathology, 155 (10): 633-640. p. DOI: $10.1111 / \mathrm{j} 1439-0434.2007 .01290 . \mathrm{x}$

37. DOBRÁNSZKI J. (2005): Alma. 118-123. p. In: Jámborné B. E., Dobránszki J. (szerk.) Kertészeti növények mikroszaporitása. Budapest: Mezőgazda Kiadó, 324 p.

38. DOBRÁNSZKI J., MAGYARNÉ T. K. (1997): A mikroszaporítás jelentősége, módszere és továbbfejlesztési lehetőségei burgonyánál. 7-16. p. In: DOBRÁNSZKI J. (szerk.): A genetikai alapok megörzése, fejlesztése hagyományos és biotechnológiai módszerekkel. Nyíregyháza: Rím Könyvkiadó, p.

39. DOBRÁNSZKI J., MAGYARNÉ T. K. (2005): A burgonya mikroszaporítása. 156-163. p. In: JÁMBORNÉ B. E., DOBRÁNSZKI J. (szerk.): Kertészeti növények mikroszaporitása. Budapest: Mezőgazda Kiadó, 324 p.

40. DOBRÁNSZKI J., TEIXEIRA DA SILVA J. A. (2010): Micropropagation of apple - a review. Biotechnology Advances, 28 (4): 462-488. p. DOI: $10.1016 /$ j.biotechadv.2010.02.008

41. DREO T., ZUPANCIC M., DEMSAR T., RAVNIKAR M. (2006): First outbreak of fire blight in Slovenia. Acta Horticulturae, 704: 37-41.p.

42. DUARTE V., DE BOER S. H., WARD L. J., DE OLIVEIRA A. M. (2004): Characterization of atypical Erwinia carotovora strains causing blackleg of potato in Brazil. Journal of Applied Microbiology, 96: 535545.p. DOI: $\underline{10.1111 / \mathrm{j} 1365-2672.2004 .02173 . \mathrm{X}}$

43. ECKERT J. W., OGAWA J. M. (1988): The chemical control of postharvest diseases: deciduous fruits, berries, vegetables and root/tuber crops. Annual Review of Phytopathology, 26: 433-469. p. DOI: 10.1146/annurev.py.26.090188.002245

44. ELKINS R. B., INGELS C. A., LINDOW S.E. (2005): Control of fire blight by Pseudomonas fluorescens A506 introduced into unopened pear flowers. Acta Horticulturae, 671: 585-594. p.

45. FANG F. C. (2011): Antimicrobial actions of reactive oxygen species. mBio 2 (5): e00141-11. DOI: 10.1128/mBio.00141-11.

46. FAO, 2012: http://faostat. fao.org/site/339/default.aspx.

47. FISCHER C. (2004): 161-164.p. In: SCHMIDT H., KELLERHALS M. (szerk.): Progress in Temperate Fruit Breeding. Nederlands: Kluwer Acad. Pub.

48. FISCHER C., FISCHER M. (1994): Härtetest für Pi- und Re-Sorten. Obstbau, 11: 537-539. p. 
49. FISCHER C., RICHTER K. (1999): Ergebnisse der resistenzzüchtung gegenüber freuerband im Pillnitzer apfelzüchtungsprogramm. Erwerbsobtbau, 41: 56-60. p.

50. FISCHER C., SCHAEFER H. J. (1990): Vergleichende Untersuchungen der Resistenz von Apfelsorten gegenüber Feuerbrand im Gewächshaus und im Freiland. Gartenbau, 37 (9): 299-300. p.

51. GARDEN L., GOUY C., CHRISTEN R., SAMSON R. (2003): Elevation of three subspecies of Pectobacterium carotovorum to species level: Pectobacterium atrosepticum sp. nov., Pectobacterium betavasculorum sp. nov. and Pectobacterium wasabiae sp. nov. International Journal of Systemic and Evolutionary Microbiology, 53: 381-391. p. DOI: $10.1099 /$ ijs.0.02423-0

52. GANAVE T., STEFANOVA M., CELlÁROVÁ E., UZUNOVA K., KOLEVA D. (2009): Structural responses of the photosynthetic apparatus of Orthosiphon stamineus Benth. to temperature stress after cryopreservation. Botanica Serbica, 33 (2): 163-167. p.

53. GILL J. J. (2000): Bacteiophages of Erwinia amylovora and their potential use in biological control. M.Sc. Thesis. Department of Biological Sciences, Brock University, St. Catherines, Ontario, Canada.

54. GRAHAM D. C. (1976): Re-infection by Erwinia carotovora (Jones) Bergey et al. in potato stocks derived from stem cuttings. EPPO Bulletin, 6: 243-245. p.

55. GROSS G. G. (1978): Biosynthesis of lignin and related monomers. Recent Advances in Phytochemistry, 11: 141-184. p.

56. HALMÁGYI T. (1997): Van-e esélyünk a tủzelhalással szemben? Agrofórum, 8 (6): 15-16. p.

57. HARRIS R. (1979): Chemical control of bacterial soft-rot of wounded potato tubers. Potato Research, 22: 245-249. p. DOI: 10.1007/BF02357357

58. HARRISON M. D., FRANC G. D., MADDOX D. A., MICHAUD J. E., MCCARTER-ZORNER N. J. (1987): Presence of Erwinia carotovora in surface water in North America. Journal of Applied Microbiology, 62: 565-570. p.

59. HARRISON M. D. In: Hooker W. J. (ed) (1990): Compedium of Potato Disease. APS PRESS, USA. 56. p.

60. HAUBEN L., MOORE E. R., VAUTERIN L. (1998): Phylogenetic position of phytopathogens within the Enterobacteriaceae. Systemic and Applied Microbiology, 21: 384-397. p. DOI: 10.1016/s07232020(98)80048-9

61. HAUBEN L., VAN GIJSEGEM F., SWINGS J. (2005): Genus XXIV. Pectobacterium. 721-730. p. In: BRENNER D. J., KRIEG N. R., STALEY J. T. (szerk.): Bergey’s Manual of Systematic bacteriology.

62. HEVESI M. (1996): Az Erwinia amylovora (Burrill) Winslow et al. hazai megjelenése almán. Növényvédelem, 32 (5): 225-228. p.

63. HEVESI, M., AL-ARABI, K., GÖNDÖR, M., PAPP, J., HONTY, K., KÁSA, K., TÓTH, M. 2006: Development of ecofriendly strategies for the control of fire blight in Hungary. Acta Hort, 704: 345-348. p.

64. HEVESI M., FARKAS Á., KÁSA K., OROSZ-KOVÁCS ZS. (2004): Carbohydrate utilization of Erwinia amylovora in vitro. International Journal of Horticultural Science, 10 (2): 31-34. p.

65. HEVESI M., PAPP J., JÁMBOR-BENCZÚR E., KASZÁNÉ CSIZMÁR K., POZSGAI I., GAZDAG GY., BALLA I. (2000): Testing the virulence of some Hungarian Erwinia amylovora strains on in vitro cultured apple rootstocks. International Journal of Horticultural Science, 6 (4): 52-55. p.

66. HIDALGO O., ECHANDI E. (1982): Evaluation of potato clones for resistance to tuber and stem rot induced by Erwinia chrysanthemi. American Journal of Potato Research, 59: 585-592. p. DOI: $10.1007 / \mathrm{BF} 02867598$

67. HIJMANS R. J., SPOONER D. M. (2001): Geographic distribution of wild potato species. American Journal of Botany, 88: 2101-2112. p.

68. HOLT-HARRIS J. E., TEAGUE O. (1916): A new culture medium for the isolation of Bacillus typhosa from stools. International Journal of Infectious Diseases, 18: 596. p.

69. HONTY K. (2010): Körtefajták tűzelhalással szembeni ellenállósága és a betegség folyamatának jellemzése néhány biokémiai paraméter vizsgálatával. Doktori értekezés, Budapesti Corvinus Egyetem.

70. HONTY K., HEVESI M., TÓTH M., STEFANIVITS-BÁNYAI É. (2005): Some biochemical changes in pear friut tissue induced by Erwinia amylovora. Acta Biologica Szegediensis, 49 (1-2): 127-129. p.

71. HONTY K., SÁRDI É., STEFANIVITS-BÁNYAI É., TÓTH M. (2008): Frost induced changes in enzyme avtivites and carbohydrate content in the spurs of some pear cultivars during the dormancy. International Journal of Horticultural Science, 14 (1-2): 41-44. p.

72. HOOKER W. J. (ed) (1990): Compedium of Potato Diseases. APS PRESS, USA. 27. p.

73. HUDÁK I., DOBRÁNSZKI J., SÁRDI É., HEVESI M. (2010): Changes in carbohydrate content of potato calli during osmotic stress induced by mannitol. Acta Biologica Hungarica 61 (2): 234-236. p.

74. HUGUELET J. E. In: Hooker W. J. (ed) (1990): Compedium of Potato Diseases. APS PRESS, USA. 57. p.

75. JAMES D. J., (1983): Adventitious root formation 'in vitro' in apple rootstocks (Malus pumila). II. Uptake and distribution of indol-acetic acid during the auxinsensitive phase in M. 9 and M. 26. Physiologia Plantarum, 57: 154-158. p.

76. JAMES D. J., THURBON I. J. (1979): Rapid in vitro rooting of the apple rootstock M9. Journal of Horticultural Science, 54: 309-311. p. 
77. JANG I. C., PARK S. Y., KIM K. Y., KWON J. G., KWAK S. S. (2004): Differential expression of 10 sweetpotato peroxidase genes in response to bacterial pathogen, Pectobacterium chrysanthemi. Plant Physiology and Biochemistry, 42 (5): 451-455. p.

78. JANSE J. D., RUISSEN M. A. (1988): Characterization and classification of Dickeya dadantii strains from several hosts in The Netherlands. Phytopathology, 78: 800-808. p.

79. JÁMBOR-BENCZÚR E., KISSIMON J., FÁBIÁN M., MÉSZÁROS A., SINKÓ Z., GAZDAG GY., NAGY T. (2001): In vitro rooting and anatomical study of leaves and roots of in vitro and ex vitro plants os Prunus $x$ davidopersica 'Piroska'. International Journal of Horticultural Science, 7 (1): 42-46. p.

80. JÁMBORNÉ B. E. (2005): A táptalaj. 49-50. p. In: JÁMBORNÉ B. E., DOBRÁNSZKI J. (szerk.) Kertészeti növények mikroszaporitása. Budapest: Mezőgazda Kiadó, 324 p.

81. JOHNSON K. B. (2000): Fire blight of apple and pear. The Plant Health Instructor. DOI: 10.1094/PHI-I2000-0726-01

82. JOHNSON K. B., STOCKWELL V.O. (1998): Management of Fire Blight: A Case Study in Microbial Ecology. Annual Review of Phytopathology, 36: 227-248. p. DOI: 10.1146/annurev.phyto.36.1.227

83. JONES L. R. (1901): Bacillus carotovorus n. sp., die Ursache einer weichen Faulnis der Mohre. Zentralbl. Bakteriol. Hyg. II. Abt. 7: 12-21. p.

84. JONES J. B., JACKSON L. E., BALOGH B., OBRADOVIC A., IRIARTE F. B., MOMOL M. T. (2007): Bacteriophages for plant disease control. Annual Review of Phytopathology, 45: 245-262. p. DOI: 10.1146/annurev.phyto.45.062806.094411

85. KAMYSZ W., KROLICKA A., BOGUCKA K., OSSOWSKI T., LUKASIAK J., LOJKOWSKA E. (2005): Antibacterial activity of synthetic peptides against plant pathogenic Pectobacterium species. Journal of Phytopathology, 153: 313-317. p.

86. KARHU S. T. (1995): The quality of applied carbohydrates affects the axillary branching of apple microshoots. Bull. Rech. Agron. Gembloux., 30 (1-2): 21-27.p.

87. KÁSA K., G. TÓTH M., PAPP J., GÖNDÖR M., HEVESI M. (2003): Történelmi almafajták, külföldi árufajták és új hibridek fogékonysága Erwinia amylovora baktériummal szemben. Növényvédelem, 39 (4): 179-184. p.

88. KASTELEIN P., SCHEPEL E., MULDER A., TURKENSTEEN L., VAN VUURDE J. (1999): Preliminary selection of antagonists of Erwinia carotovora subsp. atroseptica (Van Hall) Dye for application during green crop lifting of seed potato tubers. Potato Research, 42: 161-171. p. DOI: 10.1007/BF02358406

89. KISS I., FEHÉT T., JÁMBOR-BENCZÚR E. (1997): Comarative anatomy of stems of Hydrangea macrophylla cv. Messalina in vitro and in vivo. International Journal of Horticultural Science 29 (1-2): 7478. p.

90. KLEMENT Z. (1963): Rapid detection of the pathogenicity of phytopathogenic Pseudomonas. Nature. 199-300.p.

91. KOLOZSVÁRI NAGY J., KIRÁLY L., SCHWARCZINGER I. (2012): Phage therapy for plant disease control with a focus on fire blight. Central European Journal of Biology 7(1): 1-12.p. DOI: 10.2478/s11535-011-0093-X

92. KORBAN S. S., CHEN H. (1992): Apple. 203-227. p. In: HAMMERSCHLAG F. A., LITZ R. E. (szerk.): Biotechnology of perennial fruit crops. Wallingford: C. A. B. International.

93. KSH, 2012: www.ksh.hu/docs/hun/xstadat_eves/i_omn025.htlm

94. KSH, 2013:www.ksh.hu/docs/hun/xstadat_eves/i_omn017b.htlm

95. LAFERRIERE L. T., HELGESON J. P., ALLEN C. (1999): Fertile Solanum tuberosum + S. commersonii somatic hybrids as sources of resistance to bacterial wilt caused by Ralstonia solanacearum. Theoretical and Applied Genetics, 98: 1272-1278. p. DOI: $10.1007 / \mathrm{s} 001220051193$

96. LARCHER W. (1987): Stress bei Pflanzen. Naturwissenschaften, 74: 158-167. p.

97. LARUE P., GAULLIARD J. M. (1993): Phosetyl-Al, a new weapon against fire blight in apple and pear orchards. Acta Hort. 338: 297-304. p.

98. LAURILA J., AHOLA V., LEHTINEN A. (2008): Characterization of Dickeya strains isolated from potato and river water samples in Finland. European Journal of Plant Pathology, 122: 213-225. p.

99. LAURILA J., HANNUKKALA A., NYKYRI J. (2010): Symptoms and yield reduction caused by Dickeya spp. strains isolated from potato and river water in Finland. European Journal of Plant Pathology, 126: 249-262. p.

100. LAZAR I. (1972): Serological relationship between „amylovora”, „,carotovora” and „, herbicola” groups of the genus Erwinia. In: Maas Geesteranus H. P. (szerk.): Proceedings of the 3rd international Conference of Plant Pathogenic Bacteria, Wageningen. Pudoc, Wageningen, pp. 131-142. p.

101. LE LEZEC M., PAULIN J. P. (1984): Shoot susceptibility to fire blight of some apple cultivars. Acta Horticulturae, 151:277-281.p.

102. LE LEZEC M., PAULIN J. P., LECOMTE P. (1987): Shoot and blossom susceptibility to fire blight of apple cultivars. Acta Horticulturae, 217: 311-314. p.

103. LIM W. H. (1975): The survival of Erwinia chrysanthemi in peat and mineral soil. MARDI Research Bulletin, 3: 20-23. p. 
104. LINDOW S. E., MCGOURTY G., ELKINS R. (1996): Interactions of antibiotics with Pseudomonas fluorescens strain A506 in the control of fire blight and frost injury to pear. Phytopathology, 86 (8): 841848. p.

105. LOJKOWSKA E., KELMAN A. (1994): Comparison of the effectiveness of different methods of screening for bacterial soft rot resistance of potato tubers. American Journal of Potato Research, 71: 99-113. p.

106. LOPER J. E., HENKELS M. D. (1999): Utilization of heterologous siderophores enhances levels of iron available to Pseudomonas putida in the rhizosphere. Applied and Environmental Microbiology, 65: 53575363. p.

107. LUBAINA A. S., MURUGAN K. (2012): Biochemical characterization of oxidative burst during interaction between sesame (Sesamum indicum L.) in response to Alternaria sesami. International Journal of Advanced Biological Research, 2 (1): 2012: 86-91. p.

108. MACKAY J. M., SHIPTON P. J. (1983): Heat treatment of seed tubers for control of potato blackleg (Erwinia carotovora subsp. atroseptica) and other diseases. Plant Pathology, 32: 385-393. p.

109. MAGYARNÉ T. K., DOBRÁNSZKI J. (1997): A mikroszaporításra alapozott vetőburgonya termesztés. 30-35. p. In: DOBRÁNSZKI J. (szerk.): A genetikai alapok megörzése, fejlesztése hagyományos és biotechnológiai módszerekkel. Nyíregyháza: Rím Könyvkiadó, p.

110. MANDAL S., MITRA A., MALLICK N. (2008): Biochemical characterization of oxidative burst during interaction between Solanum lycopersicum and Fusarium oxysporum f. sp. lycopersici, Physiol. Molecular Plant Pathology, 72: 56-61. p.

111. MC CARTER-ZORNER N. J., FRANC G., HARRISON M. (1984): Soft rot Erwinia bacteria in surface and underground waters in southern Scotland and in Colorado, United States. Journal of Applied Microbiology, 57: 95-105. p.

112. MC MANNUS P. S., HEIMANN M. F. (1997): Apple, Pear and Related Trees Disorders: Fire blight. Wisconsin county Extension Office. http://polk.uwex.edu

113. MILLS A. A. S., PLATT H. W. B., HURTA R. A. R. (2006): Sensitivity of Erwinia spp. to salt compounds in vitro and their effect on the development of soft rot in potato tubers in storage. Postharvest Biology and Technology, 41: 208-214. p. DOI: 10.1016/j.postharvbio.2006.03.015

114. MILCEVICOVÁ R. (2009): Different aspects of plant responses to fire blight in apple. Doktori értekezés, Universität für Bodenkultur, Bécs. 33-57 p.

115. MITTLER R. (2002): Oxidative stress, antioxidants and stress tolerance. TRENDS in Plant Science, 7: 405410. $p$.

116. MOHAN S. K., THOMSON S. V. (1996): An outbreak of fire blight in plums. Acta Hortculturae, 411: $73-$ $76 \mathrm{p}$.

117. MOLINA J., HARRISON M. (1977): The role of Erwinia carotovora in the epidemiology of potato blackleg. I. Relationship of Erwinia carotovora var. carotovora and E. carotovora var. atroseptica to potato blackleg in Colorado. American Journal of Potato Research, 54: 587-591. p.

118. MOWRY J. B. (1964): Trans. III. State Horticultural Society, 97: 134-144. p.

119. MURARIU A., GRĂDINARIU C., STRATU A. (2008): The ecophysiological reaction of some varieties of apple tree, pear tree and quince tree to the pathogenic agents attack. Analele ştiinţifice ale Universităţii, “Al. I. Cuza” Iaşi, Tomul LIV, fasc. 1, s. II a. Biologie vegetală, 40-45 p.

120. MURASHIGE T., SKOOG F. (1962): A revised medium for rapid growth and bioassays with tobacco tissue cultures. Physiol. Plantarum 15, 473-497 p.

121. NÉMETH J. (1997): Az almatermésűek baktériumos hajtásszáradása és elhalása (tüzelhalás). Kórokozó: Erwinia amylovora. Alapvető ismeretek a betegségről és az ellene való védekezés lehetőségéröl: Szakmai információs anyag. Budapest: Agroinform Kiadó és Nyomda Kft. 32 p.

122. NÉMETH J. (1998): Occurrence and spread of fire blight (Erwinia amylovora) in Hungary (1996-1998). Management of the disease. ISHS: Proceedings of the Eight International Workshop on Fire Blight, Kusadasy, Turkey, 15-15 October. Acta Horticulturea, 489: 177-185. p.

123. NÉMETH J. (1999): Occurence and spread of fire blight (Erwinia amylovora) in Hungary (1996-1998), management of the disease. Acta Horticulturae 489: 177-185 p.

124. NÉMETH J. (2013): A burgonya baktériumos betegségei és az ellenük való védekezés. Agrofórum, 22-24. $\mathrm{p}$.

125. NOCTOR G., FOYER C. H. (1998): Ascorbate and glutathione: Keeping active oxygen under control. Annual Review of Plant Physiology and Plant Molecular Biology, 49: 249-279. p. DOI: 10.1146/annurev.arplant.49.1.249

126. OBERHOFER H. (1993). Neue Impulse für schorfresistente Apfelsorten. Obstbau-Weinbau, 7-8: 217-219. p.

127. ÖZAKTAN H., BORA T. (2006): Studies on biological control of fire blight with some antagonistic bacteria. Acta Horticulturae, 704: 337-339. p.

128. PANDHAIR V., SEKHON B. S. (2006): Reactive oxygen species and antioxidants in plants: An overview. Journal of Plant Biochemistry and Biotechnology, 15 (2):71-78. p. DOI: 10.1007/BF03321907 
129. PÁLFI K., VENDREI ZS., CSETE S., SIMON Z., SÓTONYI J., LÖRINCZNÉ IZSÁKI G. (2000): Az almatermésủek tüzelhalás betegsége (Erwinia amylovora) Magyarországon, 2000-ben. Integrált termesztés a kertészeti és szántóföldi kultúrákban, XXI: 12-17. p.

130. PÉROMBELON M. C. M., SALMOND G. P. C. (1995): Bacterial soft rots. 1-20. p. In: SINGH U. S., SINGH R. P., KOHMOTO K. (szerk.): Pathogenesis and Host Specificity in Plant Diseases, Vol. 1. Prokaryotes. Oxford, UK: Pergamon.

131. PÉROMBELON M. C. M. (1974): The role of the seed tuber in the contamination by Erwinia carotovora of potato crops in Scotland. Potato Research, 17: 187-199. p.

132. PÉROMBELON M. C. M. (1992): Potato blackleg: epidemiology, hostpathogen interaction and control. Netherlands Journal of Plant Pathology, 98: 135-146. p. DOI: 10.1007/BF01974480

133. PÉROMBELON M. C. M., HYMAN L. J. (1988): Effect of latent infection by Erwinia on yield. Scottish Crop Research Institute Annual Report. Dundee, UK. p.

134. PÉROMBELON M. C. M., KELMAN A. (1980): Ecology of the soft rot erwinias. Annual Review of Phytopathology, 18: 361-387. p. DOI: 10.1146/annurev.py.18.090180.002045

135. PÉROMBELON M. C.M., BURNETT E. M., MELVIN J. S., BLACK S. (1989): Preliminary studies on the control of potato blackleg by a hot water treatment of seed tubers. 557-566. p. In: TJAMOS E. C., BECKMAN C. H. (szerk.): Vascular Wilt Diseases of Plants: Basic Studies and Control. New York, USA: Springer-Verlag: NATO Advanced Science Institutes Series.

136. PÉROMBELON M. C. M. (2002): Potato diseases caused by soft rot erwinias: an overview of pathogenesis. Plant Pathology, 51: 1-12. p. DOI: 10.1046/j.0032-0862.2001.shorttitle.doc.x

137. PITMAN A., HARROW S., VISNOVSKY S. (2010): Genetic characterisation of Pectobacterium wasabiae causing soft rot disease of potato in New Zealand. European Journal of Plant Pathology, 126: 423-435. p.

138. RANGANNA B., KUSHALAPPA A. C., RAGHAVAN G. S. V. (1997): Ultraviolet irradiance to control dry rot and soft rot of potato in storage. Canadian Journal of Plant Pathology, 19 (1): 30-35. p.

139. RANGARAJAN M., CHAKRAVARTI B. P. (1970): Studies on the survival of corn stalk rot bacteria. Plant and Soil, 33: 140-144. p. DOI: 10.1007/BF01378206

140. RAVENSDALE M., BLOM T. J., GRACIA-GARZA J. A., SVIRCEV A. M., SMITH R. J. (2007): Bacteriophages and the control of Pectobacterium carotovorum subsp. carotovorum. Canadian Journal of Plant Pathology, 29: 121-130. p.

141. RICHTER K. (1999): Der Feuerbrand des Kernobstes (Erwinia amylovora) und Möglichkeiten seiner Bekämpfung. Erwerbsobstbau, 41:202-212 p.

142. ROBINSON K., FOSTER G. (1987): Control of potato blackleg by tuber pasteurisation: the determination of time-temperature combinations for the inactivation of pectolytic erwinia. Potato Research, 30: 121-125. p. DOI: $10.1007 / \mathrm{BF} 02357691$

143. ROEMMELT S., TREUTTER D., SPEAKMAN J. B., RADEMACHER W. (1998): Effects of Prohexadine-Ca on the flavonoid metabolism of apple with respect to plant resistance against fire blight. Acta Horticulturea, 489: 359-363. p.

144. ROITSCH T. (1999): Source-sink regulation by sugar and stress. Current Opinion of Plant Biology, 2: 198206. p.DOI: $10.1016 / \mathrm{s} 1369-5266(99) 80036-3$

145. ROSS H. (1986): Potato breeding problems and perspectives. Berlin, Germany: Paul Parey Scientific Publishers, Advances in Plant Breeding No. 13. p.

146. ROUSSELLE-BOURGEOIS F., PRIOU S. (1995): Screening tuber-bearing Solanum spp. for resistance to soft rot caused by Erwinia carotovora ssp. atroseptica (van Hall) Dye. Potato Research, 38: 111-118. p. DOI: $10.1007 / \mathrm{BF} 02358077$

147. ROWE R. C. (ed) (1993): Potato Health Management, APS PRESS, USA. 86. p.

148. RUDOLPH K., STAHMANN M. A. (1964): Interaction of peroxidases and catalases between Phaseolus vulgaris and Pseudomonas phaseolicola. Nature, 204: 474-475. p.

149. SALIN M. L. (1987): Toxic oxygen species and protective systems of the chloroplast. Physiologia Plantarum, 72: 681-689. p.

150. SAMSON R., LEGENDRE J. B., CHRISTEN R., FISCHER-LE SAUX M., ACHOUAK W., GARDAN L. (2005): Transfer of Pectobacterium chrysanthemi (Burkholder et al. 1953) Brenner et al. 1973 and Brenneria paradisiaca to the genus Dickeya gen. nov. as Dickeya chrysanthemi comb. nov. and Dickeya paradisiaca comb. nov. and delineation of four novel species, Dickeya dadantii sp. nov., Dickeya dianthicola sp. nov., Dickeya dieffenbachiae sp. nov. and Dickeya zeae sp. nov. International Journal of Systematic and Evolutionary Microbiology, 55: 1415-27. p. DOI: 10.1099/ijs.0.02791-0

151. SÁRDI É., VELICH I., HEVESI M., KLEMENT Z. (1996): The role of endogenous carbohydrates in the Phaseolus-Pseudomonas host-plantage interaction. 1. Bean ontogenesis and endogenous carbohydrate components. Hort Sci Hung, 28: 65-69. p.

152. SÁRDI É., VELICH I., HEVESI M., KLEMENT Z. (1999): Ontogenesis - and biotic stress - dependent variability of carbohydrate content in snap bean (Phaseolus vulgaris L.) Zeitschrift für Naturforschung C-A Journal of Bioscienses, 54 (9-10): 782-787. p. 
153. SÁRDI É., STEFANOVITS-BÁNYAI É. (2006): Relationship between peroxidase activity and the amount of fully-N-methylated compounds in bean plants infected by Pseudomonas savastanoi pv, phaselicola. Acta Physiologiae Plantarum, 28 (2): 523-528. p.

154. SCANDALIOS J. G. (1990): Response of plant antioxidant defense genes to environmental stress. Advances in Genetics, 28: 1-41. p.

155. SCHWARZINGER I., TÓTH M., HEVESI M. (2011): Control of Fire Blight by Bacteriophages on Apple Flowers. Acta Horticulturae, 896: 457-462. p.

156. SELYE J. (1975): Bonckés alatt a kutatás. Kriterion Könyvkiadó. Bukarest

157. SHANNON L., KAY E., LEW J. (1966): Peroxidase isozymes from Horseradish roots. Isolation and physical properties. J. Biol. Chem. 241 (9): 2166-2172. p.

158. SHARGA B. M., LYON G. D. (1998): Bacillus subtilis BS 107 as an antagonist of potato blackleg and soft rot bacteria. Canadian Journal of Microbiology, 44: 777-83. p. DOI: 10.1139/w98-064

159. SHIRSAT S., THOMAS P., NAIR P. (1991): Evaluation of treatments with hot water, chemicals and ventilated containers to reduce microbial spoilage in irradiated potatoes. Potato Research, 34: 227-231. p. DOI: $10.1007 / \mathrm{BF} 02358046$

160. SHOLBERG P. L., BEDFORD K. E., HAAG P., RANDALL P. (2001): Survey of Erwinia amylovora isolates from British Columbia for resistance to bactericides and virulence on apple. Canadian Journal of Plant Pathology, 23: 60-67. p. DOI: 10.1080/07060660109506910

161. SLAWIAK M., LOJKOWSKA E., VAN DER WOLF J. M. (2008): First report of bacterial soft rot on potato caused by Dickeya sp. (syn. Erwinia chrysanthemi) in Poland. New Disease Reports 18, 25.p.

162. SMIRNOFF N. (1998): Plant resistance to enviromental stress. Current Opinion in Biotechnology, 9: 214219. p.

163. SOBICZEWSKY P; DECKERS T., PULAWSKA J. (1997): Fire Blight (Erwinia amylovora), Some Aspects of Epidemiology and Control. Res. Inst. of Pomology and Floriculture. Poland, 43-46. p.

164. STEFANOVITS-BÁNYAI É., SÁRDI É., LAKATOS S., ZAYAN M., VELICH I. (1998): Drought stress, peroxidase activity and formaldehyde metabolism in bean plants. Acta Biologica, 49: 309-316. p.

165. STEFANOVITS-BÁNYAI É., SÁRDI É., KEREPESI I., VÉGVÁRI A., PAIS I. (2000): Effect of cadmium stress on glucose and fructose content in wheat (Triticum aestivum L.) seedlings. 275-278. p. In: GARBAN Z., DRAGAN P. (szerk.): Metal Elements in Environment, Medicine and Biology, Volume IV Proceedings of the $4^{\text {th }}$ International symposium on Metal Elements in Environment, Medicine and Biology, Timisoara, Romania.

166. STEFANOVITSNÉ BÁNYAI É. (2008): Kertészeti növények antioxidáns hatásának vizsgálata. MTA Doktori értekezés. $174 \mathrm{p}$.

167. SVIRCEV A. M., LEHMAN S. M., KIM W. S., BARSZCZ E., SCHNEIDER K. E., CASTLE A. J. (2005): Control of the fire blight pathogen with bacteriophages. $1^{\text {st }}$ Symposium Biocontrol of Bacterial Plant Diseases, 259-261. p.

168. SZECSKÓ V., HROTKÓ K., STEFANOVITS-BÁNYAI É. (2002): Seasonal variability in phenol content, peroxidase and polyphenoloxidase enzyme activity during the dormant season in plum rootstocks. Proceedingsof the $7^{\text {th }}$ Hungarian Congress on Plant Physiology, Acta Biol Szeg, 46 83-4): 211-212. p.

169. SZECSKÓ V. (2004): A fásdugványok gyökeresedö képességének fiziológiai összefüggései szilva alanyoknál. Doktori értekezés, Budapesti Corvinus Egyetem. p.

170. SZIGETI Z. (1998): Növények és a stressz. 915-984. p. In: LÁNG F. (Szerk.): Növényélettan - A növényi anyagcsere. Budapest: ELTE Eötvös Kiadó, 1000 p.

171. THOMSON S. V. (2000): Epidemiology of fire blight. 9-36. p. In: VANNESTE J. V. (szerk.). Fire Blight. The Disease and its Causative Agent, Erwinia amylovora. CABI Publishing.

172. TOTH I. K., VAN DER WOLF J. M., SADDLER G. (2011): Dickeya species: an emerging problem for potato production in Europe. Plant Pathology, 60: 385-399. p. DOI: 10.1111/j.1365-3059.2011.02427.x

173. TÓTH M. (2013a): Az alma genetikája és nemesítése. 268-270. p. In: HÖHN M., TÓTH M. (szerk.). Magyarország kultúrflórája. Az alma. Budapest: Agroinform Kiadó.

174. TÓTH M. (2013b): Gazdasági jelentőség, felhasználás - Termelés, forgalmazás. 319-326. p. In: HÖHN M., TÓTH M. (szerk.): Magyarország kultúrflórája. Az alma. Budapest: Agroinform Kiadó.

175. TÓTH M., FICZEK G., KIRÁLY I., HONTY K., HEVESI M. (2013c): Evaluation of old Carpathian apple cultivars as genetic resources of resistance to fire blight (Erwinia amylovora). Trees-Structure and Function 27 (3): 597-605 p. DOI: 10.1007/s00468-012-0814-4

176. TÓTH M. (2005): Six promising selections from the Hungarian apple breeding program for multiple resistance. International Journal of Horticultural Science, 11 (3): 23-28. p.

177. TÓTH M., FICZEK G., KIRÁLY I., KOVÁCS SZ., HEVESI M. (2012): 'Artemisz', 'Cordelia', 'Hesztia' and 'Rosmerta': New Hungarian Multiresistant Apple Cultivars. HortScience, 47 (12): 1795-1800. p.

178. TÓTH M., HEVESI M., HONTY K., KÁSA K. (2005): A Kárpátalján fellelhető alma genotípusok (régi és helyi fajták) tüzelhalással szembeni ellenállósága növényházi vizsgálatok alapján. Növényvédelem 41 (8): 341-348. p. 
179. TRIAS R., BANERAS L., MONTESINOS E., BADOSA E. (2008): Lactic acid bacteria from fresh fruit and vegetables as biocontrol agents of phytopathogenic bacteria and fungi. International Microbiology, 11: 231-236. p. DOI: $10.2436 / 20.1501 .01 .66$

180. TZENG K. C., MC GUIRE R., KELMAN A. (1990): Resistance of tubers from different potato cultivars to soft rot caused by Pectobacterium carotovorum subsp. atroseptica. American Journal of Potato Research, 67: 287-305. p. DOI: 10.1007/BF02987271

181. VAN DER MERWE J. J., COUTINHO T. A., KORSTEN L., VAN DER WAALS J. E. (2010): Pectobacterium carotovorum subsp. brasiliensis causing blackleg on potatoes in South Africa. European Journal of Plant Pathology, 126: 175-185. p.

182. VAN DER ZWET T., BEER S. V. (1995): Fire Blight - Its Nature, Prevention and Control. USDA Bulletin No. 631- 697.p.

183. VAN DER ZWET T., KEIL H. M. (1979): Fire Blight - A Bacterial Disease of Rosaceous Plants. Agriculture Handbook, 510. US Department of Agriculture, Washington, DC, 200. p.

184. VAN HALL C. J. J. (1902): Bijdragen tot de kennis der Bakterieele Plantenziekten, Amsterdam.

185. VANACKER H., CARVER T. L. W., FOYER C. H. (1998): Pathogen-induced changes in the antioxidant status of the apoplast in barley leaves. Plant Physiology, 117: 1103-1114. p.

186. VANNESTE J. L. (1996): Honey bees and epiphytic bacteria to control fire blight, a bacterial disease of apple and pear. Biocontrol News and Information, 17 (4): 67-78 p.

187. VANNESTE J. L. (2006): Biological control of fire blight: an overview of the work carried out in New Zealand. Proceedings of the 1st International symposium on Biological Control of Bacterial Plant Diseases, 408: 224-227. p.

188. VÉGVÁRI A., SÁRDI É., CSÖKE B., STEFANOVITS-BÁNYAI É., SZARKA J., VELICH I. (2000): Changing of carbohydrates by inoculation of Pseudomonas savastanoi pv. phaseolicola on bean lines with different resistance. International Journal Horticultural Science, 6 (1): 82-85 p.

189. VLASOV N. M., PEREVERZEV D. S. (1989): Resistance to black leg in potato. 789-794. p. In: KLEMENT Z. (szerk.): Plant Pathogenic Bacteria. Akadémia Kiadó, Budapest.

190. WALDEE E. L. (1945): Comparative studies of some peritrichons phytopathogenic bacteria. Iowa State Coll. J. Sci., 19: 435-484. p.

191. WALE S. J., ROBINSON K. (1986): Evaluation of large scale hot water dipping and forced ventilation of seed potatoes to reduce tuber contamination with blackleg bacteria (Erwinia spp.). British Crop Protection Conference-Pests and Diseases, 1137-1143. p.

192. WATANABE K., ORRILlO M., IWANAGA M., ORTIZ R., FREYRE R., PEREZ S. (1994): Diploid potato germplasm derived from wild and land race genetic resources. American Journal of Potato Research, 71: 599-604. p. DOI: 10.1007/BF02851525

193. WELANDER M. (1983): In vitro rooting of the apple rootstock M 26 in adult and juvenile growth phases and acclimatization of the plantlets. Physiologia Plantarum, 58 (3): 231-238. p.

194. WINSLOW C. E. A., BROADHURST J., BUCHANAN R. E., KRUMWIEDE J. R. C., ROGERS L. A., SMITH G. H. (1920): The families and genera of the bacteria. Final report of the Committee of the Society of American Bacteriologists on characterization and classification of bacterial types. Journal of Bacteriology, 5: 191-229 p.

195. WYATT G., LUND B. (1981): The effect of antibacterial products on bacterial soft rot of potatoes. Potato Research, 24: 315-329. p. DOI: 10.1007/BF02360369

196. WYEN N. V., ERDEI S., FARKAS G. L. (1971): Isolation from Avena leaf tissues of nuclease with the same specificity towards RNA and DNA. Accumulation of the enzyme during leaf senescence. Biochimica et biophysica Acta, 232: 472-483. p.

197. YEPES L. M., ALDWINCKLE H. S. (1994): Micropropagation of thirteen Malus cultivars and rootstocks, and effect of antibiotics on proliferation. Plant Growth Regulation, 15: 55-67. p. DOI: $10.1007 / \mathrm{BF} 00024677$

198. ZIMMERMAN R. H., BROOME O. C. (1980): Apple cultivar micropropagation. In: Zimmerman, R. H. (ed.) Proc. of Conf. on Nursery Production of Fruit Plants through tissue culture. Applications and Feasibility, USDA Science, ARRNE. 11: 54-58. p.

199. ZIMNOCH-GUZOWSKA E., LEBECKA R., PIETRAK J. (1999): Soft rot and blackleg reactions in diploid potato hybrids inoculated with Erwinia spp. American Journal of Potato Research, 76: 199-207. DOI: $10.1007 / \mathrm{BF} 02854222$

200. ZIMNOCH-GUZOWSKA E., ŁOJKOWSKA E. (1993): Resistance to Erwinia spp. in diploid potato with a high starch content. Potato Research, 36: 177-182. p. DOI: 10.1007/BF02360525 


\section{M2. STATISZTIKAI ÉRTÉKELÉSEK EREDMÉNYTÁBLÁZATAI}

2. táblázat. Pectobacterium carotovorum subsp. carotovorum-val történő in vitro burgonya hajtásfertőzés ANOVA táblázata

\begin{tabular}{|c|l|r|r|r|r|r|}
\hline Megfigyelési időpont & & & & & & \\
\hline 1 (fertőzést követő 1. nap) & Between Groups & 1,311 & 12 &, 109 & 6,709 &, 000 \\
\hline & Within Groups &, 423 & 26 &, 016 & & \\
\hline & Total & 1,735 & 38 & & & \\
\hline 2 (fertőzést követő 3. nap) & Between Groups & 16,512 & 12 & 1,376 & 8,585 &, 000 \\
\hline & Within Groups & 4,167 & 26 &, 160 & & \\
\hline & Total & 20,680 & 38 & & & \\
\hline 3 (fertőzést követő 7. nap) & Between Groups & 43,521 & 12 & 3,627 & 17,851 &, 000 \\
\hline & Within Groups & 5,282 & 26 &, 203 & & \\
\hline & Total & 48,803 & 38 & & & \\
\hline
\end{tabular}

3. táblázat. Pectobacterium carotovorum subsp. carotovorum-val történő in vitro burgonya hajtásfertőzés Tukey B eredmény-táblázatai

\begin{tabular}{|l|l|l|l|l|}
\hline \multicolumn{5}{|c|}{ Megfigyelési időpont=1 } \\
\hline $77365 / 103$ & & 1,000 & & \\
\hline $77399 / 514$ & & 1,000 & & \\
\hline Rachel & & 1,000 & & \\
\hline $1469 / 83$ & & 1,057 & & \\
\hline Cleopátra & & 1,070 & & \\
\hline Réka & & 1,100 & 1,100 & \\
\hline $736 / 82$ & & 1,133 & 1,133 & \\
\hline $36 / 92$ & & 1,240 & 1,240 & \\
\hline $136 / 92$ & & 1,253 & 1,253 & \\
\hline $34 / 85$ & & 1,263 & 1,263 & \\
\hline Boró & & 1,297 & 1,297 & \\
\hline Desiree & & & 1,440 & 1,440 \\
\hline $98 / 91$ & & & & 1,637 \\
\hline
\end{tabular}

\begin{tabular}{|l|l|l|l|l|}
\hline \multicolumn{5}{|c|}{ Megfigyelési időpont=2 } \\
\hline $77365 / 103$ & & 1,063 & & \\
\hline $77399 / 514$ & & 1,090 & & \\
\hline Rachel & & 1,223 & & \\
\hline $1469 / 83$ & & 1,247 & & \\
\hline Cleopátra & & 1,403 & & \\
\hline Réka & & 1,463 & & \\
\hline $736 / 82$ & & 1,690 & 1,690 & \\
\hline $36 / 92$ & & 1,837 & 1,837 & 1,837 \\
\hline $136 / 92$ & & 1,930 & 1,930 & 1,930 \\
\hline $34 / 85$ & & & 2,630 & 2,630 \\
\hline Boró & & & 2,737 & 2,737 \\
\hline Desiree & & & 2,750 & 2,750 \\
\hline $98 / 91$ & & & & 2,833 \\
\hline
\end{tabular}

\begin{tabular}{|l|r|r|r|r|r|}
\hline \multicolumn{5}{|c|}{ Megfigyelési időpont=3 } \\
\hline $77365 / 103$ & & 1,630 & & & \\
\hline Rachel & & 1,760 & & & \\
\hline $77399 / 514$ & & 2,107 & 2,107 & & \\
\hline Réka & & 2,373 & 2,373 & & \\
\hline Cleopátra & & 2,657 & 2,657 & & \\
\hline Desiree & & & 3,037 & 3,037 & \\
\hline $1469 / 83$ & & & 3,040 & 3,040 & \\
\hline $36 / 92$ & & & 3,280 & 3,280 & \\
\hline $136 / 92$ & & & & 3,930 & 3,930 \\
\hline $736 / 82$ & & & & 4,040 & 4,040 \\
\hline Boró & & & & & 4,653 \\
\hline $34 / 85$ & & & & & 4,673 \\
\hline $98 / 91$ & & & & & 4,690 \\
\hline
\end{tabular}


4. táblázat. Dickeya dadantii-val történő in vitro burgonya hajtásfertőzés ANOVA táblázata

\begin{tabular}{|c|l|r|r|r|r|r|}
\hline Megfigyelési időpont & & & & & \\
\hline 1 (fertözést követő 1. nap) & Between Groups &, 143 & 12 &, 012 & 2,828 &, 013 \\
\hline & Within Groups &, 110 & 26 &, 004 & & \\
\hline & Total &, 253 & 38 & & & \\
\hline 2 (fertözést követö 3. nap) & Between Groups & 3,749 & 12 &, 312 & 10,391 &, 000 \\
\hline & Within Groups &, 782 & 26 &, 030 & & \\
\hline & Total & 4,531 & 38 & & & \\
\hline 3 fertőzést követő 7. nap) & Between Groups & 4,770 & 12 &, 398 & 6,393 &, 000 \\
\hline & Within Groups & 1,617 & 26 &, 062 & & \\
\hline & Total & 6,387 & 38 & & & \\
\hline
\end{tabular}

5. táblázat. Dickeya dadantiivel történő in vitro burgonya hajtásfertőzés Tukey B eredmény-táblázatai

\begin{tabular}{|l|c|c|}
\hline \multicolumn{2}{|c|}{ Megfigyelési időpont=1 } \\
\hline $1469 / 83$ & & 1,0000 \\
\hline $77365 / 103$ & & 1,0000 \\
\hline $77399 / 514$ & & 1,0000 \\
\hline Rachel & & 1,0000 \\
\hline $736 / 82$ & & 1,0133 \\
\hline $34 / 85$ & & 1,0167 \\
\hline Réka & & 1,0300 \\
\hline Cleopátra & & 1,0733 \\
\hline $98 / 91$ & & 1,1000 \\
\hline $36 / 92$ & & 1,1133 \\
\hline Desiree & & 1,1233 \\
\hline $136 / 92$ & & 1,1333 \\
\hline Boró & & 1,1800 \\
\hline
\end{tabular}

\begin{tabular}{|l|l|l|l|l|l|}
\hline \multicolumn{5}{|c|}{ Megfigyelési időpont=2 } \\
\hline $34 / 85$ & 1,0633 & & & \\
\hline Rachel & & 1,0767 & & & \\
\hline $1469 / 83$ & & 1,1067 & & & \\
\hline $77399 / 514$ & & 1,1200 & & & \\
\hline $77365 / 103$ & & 1,1300 & & & \\
\hline Cleopátra & & 1,1633 & 1,1633 & & \\
\hline Réka & & 1,1667 & 1,1667 & & \\
\hline $36 / 92$ & & 1,3967 & 1,3967 & 1,3967 & \\
\hline $736 / 82$ & & 1,4767 & 1,4767 & 1,4767 & \\
\hline $98 / 91$ & & 1,4867 & 1,4867 & 1,4867 & \\
\hline Desiree & & & 1,6300 & 1,6300 & \\
\hline Boró & & & & 1,8167 & 1,8167 \\
\hline $136 / 92$ & & & & & 2,0800 \\
\hline
\end{tabular}

\begin{tabular}{|l|r|r|r|r|}
\hline \multicolumn{5}{|c|}{ Megfigyelési időpont=3 } \\
\hline $34 / 85$ & & 1,1567 & & \\
\hline Rachel & & 1,3300 & 1,3300 & \\
\hline $77399 / 514$ & & 1,3367 & 1,3367 & \\
\hline Cleopátra & & 1,4000 & 1,4000 & \\
\hline $1469 / 83$ & & 1,5733 & 1,5733 & \\
\hline $77365 / 103$ & & 1,6467 & 1,6467 & 1,6467 \\
\hline Réka & & 1,7500 & 1,7500 & 1,7500 \\
\hline $36 / 92$ & & 1,7800 & 1,7800 & 1,7800 \\
\hline $98 / 91$ & & 1,8367 & 1,8367 & 1,8367 \\
\hline $736 / 82$ & & 1,8667 & 1,8667 & 1,8667 \\
\hline Desiree & & & 1,9000 & 1,9000 \\
\hline $136 / 92$ & & & & 2,3333 \\
\hline Boró & & & & 2,3500 \\
\hline
\end{tabular}


6. táblázat. Pectobacterium carotovorum subsp. carotovorum-val történő in vitro burgonya hajtásfertőzés követő harmadik napos visszaizolálás ANOVA táblázata

\begin{tabular}{|l|l|r|r|r|r|r|}
\hline Visszaizolálás helye & & & & & \\
\hline 1 (szúrás alatt) & Between Groups & 1386089,590 & 12 & 115507,466 & 2,871 &, 002 \\
\hline & Within Groups & 4184721,333 & 104 & 40237,705 & & \\
\hline & Total & 5570810,923 & 116 & & & \\
\hline 2 (szúrás helye) & Between Groups & 6777406,564 & 12 & 564783,880 & 6,706 &, 000 \\
\hline & Within Groups & 8759488,222 & 104 & 84225,848 & & \\
\hline & Total & 15536894,786 & 116 & & & \\
\hline 3 (szúrás felett) & Between Groups & 83160,479 & 12 & 6930,040 & 4,460 &, 000 \\
\hline & Within Groups & 161599,333 & 104 & 1553,840 & & \\
\hline & Total & 244759,812 & 116 & & & \\
\hline
\end{tabular}

7. táblázat. Pectobacterium carotovorum subsp. carotovorum-val történő in vitro burgonya hajtásfertőzés követő harmadik napos visszaizolálás Tukey B eredmény-táblázatai

\begin{tabular}{|l|c|r|r|}
\hline \multicolumn{4}{|c|}{ Visszaizolálás helye=1 (szúrás alatt) } \\
\hline $1469 / 83$ & 9 & 4,22 & \\
\hline $77399 / 514$ & 9 & 5,33 & \\
\hline Rachel & 9 & 5,89 & \\
\hline $77365 / 103$ & 9 & 7,67 & \\
\hline Cleopátra & 9 & 39,89 & \\
\hline Réka & 9 & 90,44 & 90,44 \\
\hline $34 / 85$ & 9 & 107,22 & 107,22 \\
\hline Desiree & 9 & 146,44 & 146,44 \\
\hline $736 / 82$ & 9 & 160,22 & 160,22 \\
\hline $36 / 92$ & 9 & 189,00 & 189,00 \\
\hline $136 / 92$ & 9 & 218,00 & 218,00 \\
\hline Boró & 9 & 247,89 & 247,89 \\
\hline $98 / 91$ & 9 & & 367,78 \\
\hline
\end{tabular}

\begin{tabular}{|l|c|r|l|l|}
\hline \multicolumn{5}{|c|}{ Visszaizolálás helye=2 (szúrás helye) } \\
\hline $77399 / 514$ & 9 & 7,33 & & \\
\hline Rachel & 9 & 11,56 & & \\
\hline $77365 / 103$ & 9 & 14,78 & & \\
\hline $1469 / 83$ & 9 & 24,89 & & \\
\hline Cleopátra & 9 & 55,56 & & \\
\hline Réka & 9 & 105,67 & 105,67 & \\
\hline $34 / 85$ & 9 & 133,33 & 133,33 & \\
\hline Desiree & 9 & 178,56 & 178,56 & \\
\hline $736 / 82$ & 9 & 190,33 & 190,33 & \\
\hline $36 / 92$ & 9 & 219,11 & 219,11 & \\
\hline $136 / 92$ & 9 & 253,44 & 253,44 & \\
\hline Boró & 9 & & 514,00 & \\
\hline $98 / 91$ & 9 & & & 892,00 \\
\hline
\end{tabular}

\begin{tabular}{|l|r|r|r|}
\hline \multicolumn{4}{|c|}{ Visszaizolálás helye=3 (szúrás felett) } \\
\hline $77365 / 103$ & 9 &, 00 & \\
\hline $77399 / 514$ & 9 &, 00 & \\
\hline Rachel & 9 &, 00 & \\
\hline $1469 / 83$ & 9 & 1,22 & \\
\hline Cleopátra & 9 & 2,33 & \\
\hline Réka & 9 & 5,33 & \\
\hline $34 / 85$ & 9 & 8,33 & \\
\hline Desiree & 9 & 13,22 & \\
\hline $736 / 82$ & 9 & 22,44 & \\
\hline $36 / 92$ & 9 & 29,56 & \\
\hline $136 / 92$ & 9 & 42,67 & 42,67 \\
\hline Boró & 9 & 61,22 & 61,22 \\
\hline $98 / 91$ & 9 & & 88,44 \\
\hline
\end{tabular}


8. táblázat. Pectobacterium carotovorum subsp. carotovorum-val történő in vitro burgonya hajtásfertőzés követő hetedik napos visszaizolálás ANOVA táblázata

\begin{tabular}{|l|l|r|r|r|r|r|}
\hline Visszaizolálás helye & & & & & \\
\hline 1 (szúrás alatt) & Between Groups & 11117707,556 & 12 & 926475,630 & 4,075 &, 000 \\
\hline & Within Groups & 23647274,667 & 104 & 227377,641 & & \\
\hline & Total & 34764982,222 & 116 & & & \\
\hline 2 (szúrás helye) & Between Groups & 9427664,632 & 12 & 785638,719 & 4,021 &, 000 \\
\hline & Within Groups & 20318538,667 & 104 & 195370,564 & & \\
\hline & Total & 29746203,299 & 116 & & & \\
\hline 3 (szúrás felett) & Between Groups & 10888691,692 & 12 & 907390,974 & 5,529 &, 000 \\
\hline & Within Groups & 17067846,000 & 104 & 164113,904 & & \\
\hline & Total & 27956537,692 & 116 & & & \\
\hline
\end{tabular}

9. táblázat. Pectobacterium carotovorum subsp. carotovorum-val történő in vitro burgonya hajtásfertőzés követő hetedik napos visszaizolálás Tukey B eredmény-táblázatai

\begin{tabular}{|l|c|r|r|}
\hline \multicolumn{4}{|c|}{ Visszaizolálás helye=1 (szúrás alatt) } \\
\hline $77365 / 103$ & 9 & 31,00 & \\
\hline $136 / 92$ & 9 & 55,78 & \\
\hline Rachel & 9 & 59,89 & \\
\hline $77399 / 514$ & 9 & 70,11 & \\
\hline Cleopátra & 9 & 87,56 & \\
\hline Réka & 9 & 100,89 & \\
\hline Desiree & 9 & 130,78 & \\
\hline $1469 / 83$ & 9 & 161,78 & \\
\hline $36 / 92$ & 9 & 225,00 & \\
\hline $736 / 82$ & 9 & 338,33 & \\
\hline Boró & 9 & 421,44 & \\
\hline $34 / 85$ & 9 & 577,89 & 577,89 \\
\hline $98 / 91$ & 9 & & 1181,67 \\
\hline
\end{tabular}

\begin{tabular}{|l|c|r|l|}
\hline \multicolumn{4}{|c|}{ Visszaizolálás helye=2 (szúrás helye) } \\
\hline $77365 / 103$ & 9 & 14,44 & \\
\hline Rachel & 9 & 20,33 & \\
\hline $77399 / 514$ & 9 & 32,67 & \\
\hline Réka & 9 & 69,00 & \\
\hline Cleopátra & 9 & 76,00 & \\
\hline Desiree & 9 & 109,89 & \\
\hline $1469 / 83$ & 9 & 135,00 & \\
\hline $36 / 92$ & 9 & 177,56 & \\
\hline $34 / 85$ & 9 & 242,44 & \\
\hline $736 / 82$ & 9 & 264,11 & \\
\hline Boró & 9 & 275,33 & \\
\hline $136 / 92$ & 9 & 280,67 & \\
\hline $98 / 91$ & 9 & & 1145,44 \\
\hline
\end{tabular}

\begin{tabular}{|l|r|r|r|}
\hline \multicolumn{4}{|c|}{ Visszaizolálás helye=3 (szúrás felett) } \\
\hline $77399 / 514$ & 9 & 6,11 & \\
\hline $77365 / 103$ & 9 & 6,33 & \\
\hline Rachel & 9 & 7,44 & \\
\hline Cleopátra & 9 & 7,67 & \\
\hline Réka & 9 & 9,56 & \\
\hline Desiree & 9 & 12,22 & \\
\hline $1469 / 83$ & 9 & 18,78 & \\
\hline Boró & 9 & 18,78 & \\
\hline $34 / 85$ & 9 & 28,00 & \\
\hline $36 / 92$ & 9 & 28,78 & \\
\hline $736 / 82$ & 9 & 64,11 & \\
\hline $136 / 92$ & 9 & 332,22 & \\
\hline $98 / 91$ & 9 & & 1145,00 \\
\hline
\end{tabular}


10. táblázat. Dickeya dadantii-val történő in vitro burgonya hajtásfertőzés követő harmadik napos visszaizolálás ANOVA táblázata

\begin{tabular}{|l|l|r|r|r|r|r|}
\hline Visszaizolálás helye & & & & & \\
\hline 1 (szúrás alatt) & Between Groups & 810212,103 & 12 & 67517,675 & 3,430 &, 000 \\
\hline & Within Groups & 2047334,667 & 104 & 19685,910 & & \\
\hline & Total & 2857546,769 & 116 & & & \\
\hline 2 (szúrás helye) & Between Groups & 1967413,453 & 12 & 163951,121 & 2,968 &, 001 \\
\hline & Within Groups & 5745083,333 & 104 & 55241,186 & & \\
\hline & Total & 7712496,786 & 116 & & & \\
\hline 3 (szúrás felett) & Between Groups & 86312,530 & 12 & 7192,711 & 3,925 &, 000 \\
\hline & Within Groups & 190575,778 & 104 & 1832,459 & & \\
\hline & Total & 276888,308 & 116 & & & \\
\hline
\end{tabular}

11. táblázat. Dickeya dadantii-val történő in vitro burgonya hajtásfertőzés követő harmadik napos visszaizolálás Tukey B eredmény-táblázatai

\begin{tabular}{|l|c|r|r|}
\hline \multicolumn{4}{|c|}{ Visszaizolálás helye=1 (szúrás alatt) } \\
\hline $34 / 85$ & 9 & 3,00 & \\
\hline Rachel & 9 & 4,56 & \\
\hline $1469 / 83$ & 9 & 9,67 & \\
\hline $36 / 92$ & 9 & 12,89 & \\
\hline $77365 / 103$ & 9 & 16,56 & \\
\hline Réka & 9 & 25,22 & \\
\hline Cleopátra & 9 & 28,11 & \\
\hline Desiree & 9 & 42,89 & \\
\hline $77399 / 514$ & 9 & 52,33 & \\
\hline $736 / 82$ & 9 & 119,78 & 119,78 \\
\hline Boró & 9 & 144,78 & 144,78 \\
\hline $98 / 91$ & 9 & 161,89 & 161,89 \\
\hline $136 / 92$ & 9 & & 294,00 \\
\hline
\end{tabular}

\begin{tabular}{|l|c|r|r|}
\hline \multicolumn{4}{|c|}{ Visszaizolálás helye=2 (szúrás helye) } \\
\hline $34 / 85$ & 9 & 4,00 & \\
\hline Rachel & 9 & 8,11 & \\
\hline $1469 / 83$ & 9 & 33,00 & 33,00 \\
\hline Réka & 9 & 37,11 & 37,11 \\
\hline $36 / 92$ & 9 & 42,33 & 42,33 \\
\hline $77365 / 103$ & 9 & 58,78 & 58,78 \\
\hline Cleopátra & 9 & 61,33 & 61,33 \\
\hline $77399 / 514$ & 9 & 64,33 & 64,33 \\
\hline $736 / 82$ & 9 & 165,33 & 165,33 \\
\hline $98 / 91$ & 9 & 185,67 & 185,67 \\
\hline Desiree & 9 & 230,89 & 230,89 \\
\hline Boró & 9 & & 379,78 \\
\hline $136 / 92$ & 9 & & 396,78 \\
\hline
\end{tabular}

\begin{tabular}{|l|r|r|r|r|}
\hline \multicolumn{5}{|c|}{ Visszaizolálás helye=3 (szúrás felett) } \\
\hline Rachel & 9 &, 00 & & \\
\hline $34 / 85$ & 9 &, 22 & & \\
\hline $77399 / 514$ & 9 &, 22 & & \\
\hline Desiree & 9 & 3,44 & & \\
\hline $36 / 92$ & 9 & 4,22 & & \\
\hline $1469 / 83$ & 9 & 4,56 & & \\
\hline $77365 / 103$ & 9 & 5,33 & & \\
\hline Cleopátra & 9 & 11,56 & & \\
\hline $98 / 91$ & 9 & 15,89 & 15,89 & \\
\hline Réka & 9 & 23,22 & 23,22 & \\
\hline $736 / 82$ & 9 & 27,67 & 27,67 & 27,67 \\
\hline Boró & 9 & & 76,00 & 76,00 \\
\hline $136 / 92$ & 9 & & & 84,33 \\
\hline
\end{tabular}


12. táblázat. Dickeya dadantii-val történő in vitro burgonya hajtásfertőzés követö hetedik napos visszaizolálás ANOVA táblázata

\begin{tabular}{|l|l|r|r|r|r|r|}
\hline Visszaizolálás helye & & & & & \\
\hline 1 (szúrás alatt) & Between Groups & 764950,581 & 12 & 63745,882 & 2,985 &, 001 \\
\hline & Within Groups & 2220831,333 & 104 & 21354,147 & & \\
\hline & Total & 2985781,915 & 116 & & & \\
\hline 2 (szúrás helye) & Between Groups & 6429062,325 & 12 & 535755,194 & 4,514 &, 000 \\
\hline & Within Groups & 12343308,444 & 104 & 118685,658 & & \\
\hline & Total & 18772370,769 & 116 & & & \\
\hline 3 (szúrás felett) & Between Groups & 84152,444 & 12 & 7012,704 & 4,346 &, 000 \\
\hline & Within Groups & 167827,111 & 104 & 1613,722 & & \\
\hline & Total & 251979,556 & 116 & & & \\
\hline
\end{tabular}

13. táblázat. Dickeya dadantii-val történő in vitro burgonya hajtásfertőzés követő hetedik napos visszaizolálás Tukey B eredmény-táblázatai

\begin{tabular}{|l|c|r|r|}
\hline \multicolumn{4}{|c|}{ Visszaizolálás helye=1 (szúrás alatt) } \\
\hline Rachel & 9 & 32,11 & \\
\hline $77399 / 514$ & 9 & 35,56 & \\
\hline $1469 / 83$ & 9 & 36,11 & \\
\hline $34 / 85$ & 9 & 36,67 & \\
\hline Cleopátra & 9 & 37,22 & \\
\hline $36 / 92$ & 9 & 39,00 & \\
\hline $77365 / 103$ & 9 & 44,67 & \\
\hline Réka & 9 & 44,67 & \\
\hline Boró & 9 & 125,67 & 125,67 \\
\hline $98 / 91$ & 9 & 135,33 & 135,33 \\
\hline Desiree & 9 & 170,67 & 170,67 \\
\hline $736 / 82$ & 9 & 195,44 & 195,44 \\
\hline $136 / 92$ & 9 & & 296,78 \\
\hline
\end{tabular}

\begin{tabular}{|l|c|r|l|}
\hline \multicolumn{4}{|c|}{ Visszaizolálás helye=2 (szúrás helye) } \\
\hline $34 / 85$ & 9 & 40,33 & \\
\hline Rachel & 9 & 55,56 & \\
\hline $77399 / 514$ & 9 & 56,67 & \\
\hline Cleopátra & 9 & 78,33 & \\
\hline $1469 / 83$ & 9 & 78,89 & \\
\hline $77365 / 103$ & 9 & 85,11 & \\
\hline Réka & 9 & 96,11 & \\
\hline $36 / 92$ & 9 & 109,56 & \\
\hline $98 / 91$ & 9 & 179,89 & \\
\hline $736 / 82$ & 9 & 201,78 & \\
\hline Desiree & 9 & 242,00 & \\
\hline $136 / 92$ & 9 & 397,33 & \\
\hline Boró & 9 & & \\
\hline
\end{tabular}

\begin{tabular}{|l|c|r|r|}
\hline \multicolumn{4}{|c|}{ Visszaizolálás helye=3 (szúrás felett) } \\
\hline Réka & 9 & 1,11 & \\
\hline $77399 / 514$ & 9 & 1,22 & \\
\hline $36 / 92$ & 9 & 2,00 & \\
\hline Rachel & 9 & 3,11 & \\
\hline $77365 / 103$ & 9 & 4,22 & \\
\hline $34 / 85$ & 9 & 4,33 & \\
\hline $1469 / 83$ & 9 & 5,00 & \\
\hline Cleopátra & 9 & 5,67 & \\
\hline $98 / 91$ & 9 & 7,00 & \\
\hline $736 / 82$ & 9 & 8,00 & \\
\hline Desiree & 9 & 20,33 & \\
\hline Boró & 9 & & 76,56 \\
\hline $136 / 92$ & 9 & & 81,00 \\
\hline
\end{tabular}


14. táblázat. Pectobacterium carotovorum subsp. carotovorum-val történő in vitro burgonya gumófertőzés ANOVA táblázata

\begin{tabular}{|c|l|r|r|r|r|r|}
\hline Időpont & & & & & \\
\hline 1 (fertözést követö 1. nap) & Between Groups & 215,292 & 12 & 17,941 & 6,330 &, 000 \\
\hline & Within Groups & 1011,800 & 357 & 2,834 & & \\
\hline & Total & 1227,092 & 369 & & & \\
\hline 2 (fertőzést követö 3. nap) & Between Groups & 194,169 & 12 & 16,181 & 4,714 &, 000 \\
\hline & Within Groups & 1225,333 & 357 & 3,432 & & \\
\hline & Total & 1419,503 & 369 & & & \\
\hline 3 fertőzést követö 7. nap) & Between Groups & 34,658 & 12 & 2,888 &, 933 &, 514 \\
\hline & Within Groups & 1105,367 & 357 & 3,096 & & \\
\hline & Total & 1140,024 & 369 & & & \\
\hline
\end{tabular}

15. táblázat. Pectobacterium carotovorum subsp. carotovorum-val történő in vitro burgonya gumófertőzés Tukey B eredménytáblázatai

\begin{tabular}{|l|l|l|l|}
\hline \multicolumn{4}{|c|}{ időpont=1 } \\
\hline $98 / 91$ & 30 & 1,27 & \\
\hline Rachel & 10 & 1,30 & \\
\hline $34 / 85$ & 30 & 1,33 & \\
\hline Cleopátra & 30 & 2,17 & 2,17 \\
\hline $36 / 92$ & 30 & 2,67 & 2,67 \\
\hline Réka & 30 & 2,70 & 2,70 \\
\hline $136 / 92$ & 30 & & 2,80 \\
\hline Desiree & 30 & & 2,87 \\
\hline $77365 / 103$ & 30 & & 2,93 \\
\hline Boró & 30 & & 3,13 \\
\hline $77399 / 514$ & 30 & & 3,20 \\
\hline $1469 / 83$ & 30 & & 3,63 \\
\hline $736 / 82$ & 30 & & 3,67 \\
\hline
\end{tabular}

\begin{tabular}{|l|l|r|r|r|}
\hline \multicolumn{5}{|c|}{ időpont=2 } \\
\hline $98 / 91$ & 30 & 1,33 & & \\
\hline Rachel & 10 & 1,80 & 1,80 & \\
\hline $34 / 85$ & 30 & 2,87 & 2,87 & 2,87 \\
\hline $36 / 92$ & 30 & 2,87 & 2,87 & 2,87 \\
\hline Cleopátra & 30 & 2,87 & 2,87 & 2,87 \\
\hline Réka & 30 & & 3,00 & 3,00 \\
\hline Desiree & 30 & & 3,30 & 3,30 \\
\hline Boró & 30 & & 3,33 & 3,33 \\
\hline $77365 / 103$ & 30 & & & 3,73 \\
\hline $136 / 92$ & 30 & & & 3,80 \\
\hline $1469 / 83$ & 30 & & & 3,83 \\
\hline $736 / 82$ & 30 & & & 3,83 \\
\hline $77399 / 514$ & 30 & & & 3,90 \\
\hline
\end{tabular}

\begin{tabular}{|l|l|l|l|}
\hline \multicolumn{4}{|c|}{ időpont=3 } \\
\hline Rachel & 10 & 2,60 & \\
\hline $34 / 85$ & 30 & 3,53 & 3,53 \\
\hline $36 / 92$ & 30 & 3,80 & 3,80 \\
\hline Réka & 30 & 3,80 & 3,80 \\
\hline Boró & 30 & 3,80 & 3,80 \\
\hline $77399 / 514$ & 30 & 3,93 & 3,93 \\
\hline $77365 / 103$ & 30 & 4,07 & 4,07 \\
\hline $1469 / 83$ & 30 & 4,07 & 4,07 \\
\hline Desiree & 30 & 4,07 & 4,07 \\
\hline $736 / 82$ & 30 & 4,10 & 4,10 \\
\hline $136 / 92$ & 30 & 4,13 & 4,13 \\
\hline Cleopátra & 30 & 4,20 & 4,20 \\
\hline $98 / 91$ & 30 & & 4,33 \\
\hline
\end{tabular}


16. táblázat. Dickeya dadantii-val történő in vitro burgonya gumófertőzés ANOVA táblázata

\begin{tabular}{|l|l|l|r|r|r|r|r|}
\hline \multicolumn{1}{|c|}{ Időpont } & & & & & & \\
\hline 1 (fertőzést követö 1. nap) & 1 & $\begin{array}{l}\text { Between } \\
\text { Groups }\end{array}$ & 70,716 & 12 & 5,893 & 2,860 &, 001 \\
\hline & & Within Groups & 745,833 & 362 & 2,060 & & \\
\hline & & Total & 816,549 & 374 & & & \\
\hline 2 (fertőzést követö 3. nap) & 1 & $\begin{array}{l}\text { Between } \\
\text { Groups }\end{array}$ & 98,236 & 12 & 8,186 & 2,228 &, 010 \\
\hline & & Within Groups & 1330,100 & 362 & 3,674 & & \\
\hline & & Total & 1428,336 & 374 & & & \\
\hline & 2 (kontroll) & $\begin{array}{l}\text { Between } \\
\text { Groups }\end{array}$ & 21,217 & 12 & 1,768 & 1,988 &, 024 \\
\hline & & Within Groups & 321,940 & 362 &, 889 & & \\
\hline 3 (fertőzést követö 7. nap) & 1 & Total & 343,157 & 374 & & & \\
\hline & & $\begin{array}{l}\text { Between } \\
\text { Groups }\end{array}$ & 177,823 & 12 & 14,819 & 4,481 &, 000 \\
\hline & & Within Groups & 1197,110 & 362 & 3,307 & & \\
\hline
\end{tabular}

17. táblázat. Dickeya dadantii-val történő in vitro burgonya gumófertőzés Tukey B eredménytáblázatai

\begin{tabular}{|l|l|r|r|}
\hline \multicolumn{4}{|c|}{ időpont=1 kezelés=1 (fertőzött) } \\
\hline $77399 / 514$ & 30 & 1,17 & \\
\hline $36 / 92$ & 25 & 1,60 & 1,60 \\
\hline $136 / 92$ & 30 & 1,60 & 1,60 \\
\hline $34 / 85$ & 30 & 1,63 & 1,63 \\
\hline $736 / 82$ & 30 & 1,77 & 1,77 \\
\hline Réka & 30 & 1,80 & 1,80 \\
\hline $1469 / 83$ & 20 & 1,90 & 1,90 \\
\hline $98 / 91$ & 30 & 1,93 & 1,93 \\
\hline Desiree & 30 & 2,00 & 2,00 \\
\hline $77365 / 103$ & 30 & 2,37 & 2,37 \\
\hline Rachel & 30 & & 2,43 \\
\hline Boró & 30 & & 2,53 \\
\hline Cleopátra & 30 & & 2,73 \\
\hline
\end{tabular}

\begin{tabular}{|l|l|r|r|}
\hline \multicolumn{3}{|c|}{ időpont=2 kezelés=1 (fertőzött) } \\
\hline $77399 / 514$ & 30 & 1,73 & \\
\hline $34 / 85$ & 30 & 2,23 & 2,23 \\
\hline $136 / 92$ & 30 & 2,47 & 2,47 \\
\hline $36 / 92$ & 25 & 2,60 & 2,60 \\
\hline $98 / 91$ & 30 & 2,73 & 2,73 \\
\hline Réka & 30 & 2,73 & 2,73 \\
\hline $1469 / 83$ & 20 & 2,80 & 2,80 \\
\hline $736 / 82$ & 30 & 3,10 & 3,10 \\
\hline Rachel & 30 & 3,10 & 3,10 \\
\hline $77365 / 103$ & 30 & 3,13 & 3,13 \\
\hline Desiree & 30 & 3,13 & 3,13 \\
\hline Cleopátra & 30 & & 3,53 \\
\hline Boró & 30 & & 3,67 \\
\hline
\end{tabular}

\begin{tabular}{|l|l|r|r|r|}
\hline \multicolumn{5}{|c|}{ időpont=3 kezelés=1 (fertőzött) } \\
\hline $77399 / 514$ & 30 & 1,93 & & \\
\hline $136 / 92$ & 30 & 2,60 & 2,60 & \\
\hline $34 / 85$ & 30 & 2,97 & 2,97 & 2,97 \\
\hline Réka & 30 & 3,00 & 3,00 & 3,00 \\
\hline $1469 / 83$ & 20 & 3,15 & 3,15 & 3,15 \\
\hline $36 / 92$ & 25 & 3,16 & 3,16 & 3,16 \\
\hline $736 / 82$ & 30 & 3,20 & 3,20 & 3,20 \\
\hline $77365 / 103$ & 30 & & 3,70 & 3,70 \\
\hline Rachel & 30 & & 3,97 & 3,97 \\
\hline $98 / 91$ & 30 & & 4,07 & 4,07 \\
\hline Desiree & 30 & & 4,07 & 4,07 \\
\hline Cleopátra & 30 & & 4,10 & 4,10 \\
\hline Boró & 30 & & & 4,33 \\
\hline
\end{tabular}

\begin{tabular}{|l|l|c|}
\hline \multicolumn{3}{|c|}{ időpont=2 kezelés=2 (kontroll) } \\
\hline $1469 / 83$ & 20 & 1,00 \\
\hline $34 / 85$ & 30 & 1,03 \\
\hline $136 / 92$ & 30 & 1,03 \\
\hline $98 / 91$ & 30 & 1,03 \\
\hline $77365 / 103$ & 30 & 1,10 \\
\hline $36 / 92$ & 25 & 1,12 \\
\hline $736 / 82$ & 30 & 1,23 \\
\hline $77399 / 514$ & 30 & 1,27 \\
\hline Boró & 30 & 1,37 \\
\hline Desiree & 30 & 1,40 \\
\hline Cleopátra & 30 & 1,53 \\
\hline Réka & 30 & 1,63 \\
\hline Rachel & 30 & 1,73 \\
\hline
\end{tabular}


18. táblázat. Pectobacterium carotovorum subsp. carotovorum-val történő üvegházi burgonya gumófertőzés ANOVA táblázata

\begin{tabular}{|l|r|r|r|r|r|}
\hline \multicolumn{1}{|c|}{$\%$} & \multicolumn{1}{|c|}{$\begin{array}{c}\text { Sum of } \\
\text { Squares }\end{array}$} & \multicolumn{1}{c|}{ Df } & $\begin{array}{c}\text { Mean } \\
\text { Square }\end{array}$ & F & Sig. \\
\hline Between Groups & 61458,171 & 12 & 5121,514 & 11,327 &, 000 \\
\hline Within Groups & 220194,182 & 487 & 452,144 & & \\
\hline Total & 281652,354 & 499 & & & \\
\hline
\end{tabular}

19. táblázat. Pectobacterium carotovorum subsp. carotovorum-val történő üvegházi burgonya gumófertőzés Tukey B eredménytáblázatai

\begin{tabular}{|l|l|r|r|r|r|r|}
\hline \multicolumn{1}{|c|}{ Fajta } & $\mathbf{N}$ & $\mathbf{1}$ & $\mathbf{2}$ & $\mathbf{3}$ & $\mathbf{4}$ & $\mathbf{5}$ \\
\hline Réka & 40 & 3,8698 & & & & \\
\hline $36 / 92$ & 40 & 6,4593 & & & & \\
\hline $1469 / 83$ & 40 & 8,7528 & & & & \\
\hline $34 / 85$ & 40 & 11,3808 & 11,3808 & & & \\
\hline $77365 / 103$ & 40 & 13,8620 & 13,8620 & 13,8620 & & \\
\hline $736 / 82$ & 40 & 16,9950 & 16,9950 & 16,9950 & 16,9950 & \\
\hline Rachel & 40 & & 24,2953 & 24,2953 & 24,2953 & 24,2953 \\
\hline Desiree & 40 & & & 26,6768 & 26,6768 & 26,6768 \\
\hline $98 / 91$ & 40 & & & 28,7568 & 28,7568 & 28,7568 \\
\hline Boró & 40 & & & & 31,2528 & 31,2528 \\
\hline Cleopátra & 20 & & & & & 32,9925 \\
\hline $136 / 92$ & 40 & & & & & 33,5675 \\
\hline $77399 / 514$ & 40 & & & & & 37,8598 \\
\hline
\end{tabular}


20. táblázat. Dickeya dadantii-val történő üvegházi burgonya gumófertőzés ANOVA táblázata

\begin{tabular}{|l|r|r|r|r|r|}
\hline \multicolumn{1}{|c|}{$\%$} & \multicolumn{1}{c|}{$\begin{array}{c}\text { Sum of } \\
\text { Squares }\end{array}$} & \multicolumn{1}{c|}{ Df } & \multicolumn{1}{c|}{$\begin{array}{c}\text { Mean } \\
\text { Square }\end{array}$} & F & \multicolumn{1}{c|}{ Sig. } \\
\hline Between Groups & 64935,902 & 12 & 5411,325 & 9,430 &, 000 \\
\hline Within Groups & 290944,115 & 507 & 573,854 & & \\
\hline Total & 355880,016 & 519 & & & \\
\hline
\end{tabular}

21. táblázat. Dickeya dadantii-val történő üvegházi burgonya gumófertőzés Tukey B eredménytáblázatai

\begin{tabular}{|c|c|c|c|c|c|c|c|}
\hline Fajta & $\bar{N}$ & 1 & 2 & 3 & 4 & 5 & 6 \\
\hline Cleopátra & 40 & 2,70 & & & & & \\
\hline $1469 / 83$ & 40 & 9,27 & 9,27 & & & & \\
\hline Réka & 40 & 15,79 & 15,79 & 15,79 & & & \\
\hline $36 / 92$ & 40 & 18,42 & 18,42 & 18,42 & 18,42 & & \\
\hline $34 / 85$ & 40 & & 19,96 & 19,96 & 19,96 & & \\
\hline $77365 / 103$ & 40 & & 21,33 & 21,33 & 21,33 & & \\
\hline $98 / 91$ & 40 & & 23,36 & 23,36 & 23,36 & & \\
\hline Rachel & 40 & & 25,14 & 25,14 & 25,14 & 25,14 & \\
\hline $736 / 82$ & 40 & & & 29,88 & 29,88 & 29,88 & 29,88 \\
\hline Desiree & 40 & & & 32,09 & 32,09 & 32,09 & 32,09 \\
\hline $136 / 92$ & 40 & & & & 33,73 & 33,73 & 33,73 \\
\hline Boró & 40 & & & & & 40,76 & 40,76 \\
\hline $77399 / 514$ & 40 & & & & & & 42,82 \\
\hline
\end{tabular}

22. táblázat. Erwinia amylovora-val történő in vitro alma hajtásfertőzés ANOVA táblázata

\begin{tabular}{|c|c|c|c|c|c|c|c|}
\hline Kezelés & Időpont & & & & & & \\
\hline \multirow[t]{9}{*}{1 (fertőzött) } & 1 (fertőzést követő 2. nap) & Between Groups & 28,335 & 6 & 4,723 & 23,635 & 000 \\
\hline & & Within Groups & 60,944 & 305 & 200 & & \\
\hline & & Total & 89,279 & 311 & & & \\
\hline & 2 (fertőzést követő 5. nap) & Between Groups & 88,488 & 6 & 14,748 & 15,951 &, 000 \\
\hline & & Within Groups & 281,081 & 304 & ,925 & & \\
\hline & & Total & 369,569 & 310 & & & \\
\hline & 3 (fertőzést követő 8. nap) & Between Groups & 110,934 & 6 & 18,489 & 17,016 & 000 \\
\hline & & Within Groups & 310,759 & 286 & 1,087 & & \\
\hline & & Total & 421,693 & 292 & & & \\
\hline \multirow[t]{9}{*}{2 (kontroll) } & 1 (fertőzést követő 2. nap) & Between Groups &, 452 & 6 & 075 & 1,697 &, 140 \\
\hline & & Within Groups & 2,400 & 54 & 044 & & \\
\hline & & Total & 2,852 & 60 & & & \\
\hline & 2 (fertőzést követö 5. nap) & Between Groups & 1,369 & 6 & 228 & 1,460 & ,210 \\
\hline & & Within Groups & 8,281 & 53 & 156 & & \\
\hline & & Total & 9,650 & 59 & & & \\
\hline & 3 (fertőzést követő 8. nap) & Between Groups & 2,302 & 6 & ,384 & 1,904 & ,097 \\
\hline & & Within Groups & 10,681 & 53 & ,202 & & \\
\hline & & Total & 12,983 & 59 & & & \\
\hline
\end{tabular}


23. táblázat. Erwinia amylovora-val történő in vitro alma hajtásfertőzés Tukey B eredménytáblázatai

\begin{tabular}{|l|r|r|r|r|}
\hline \multicolumn{5}{|c|}{ kezelés=1 (fertőzött) időpont=1 } \\
\hline $\begin{array}{l}\text { Húsvéti } \\
\text { rozmaring }\end{array}$ & 52 &, 12 & & \\
\hline Red Fuji & 46 &, 20 & & \\
\hline Freedom & 46 &, 20 & & \\
\hline Tenroy & 45 & &, 51 & \\
\hline Hesztia & 37 & &, 51 & \\
\hline Idared & 36 & &, 75 &, 75 \\
\hline Jonagold & 50 & & &, 96 \\
\hline
\end{tabular}

\begin{tabular}{|l|c|r|r|r|}
\hline \multicolumn{5}{|c|}{ kezelés=1 (fertőzött) időpont=3 } \\
\hline Red Fuji & 43 & 2,93 & & \\
\hline Freedom & 43 & 3,42 & 3,42 & \\
\hline Idared & 33 & & 3,79 & \\
\hline $\begin{array}{l}\text { Húsvéti } \\
\text { rozmaring }\end{array}$ & 48 & & 3,83 & \\
\hline Hesztia & 34 & & 3,85 & \\
\hline Tenroy & 42 & & & 4,69 \\
\hline Jonagold & 50 & & & 4,72 \\
\hline
\end{tabular}

\begin{tabular}{|l|c|r|}
\hline \multicolumn{3}{|c|}{ kezelés=2 (kontroll) időpont=1 } \\
\hline Idared & 5 &, 00 \\
\hline $\begin{array}{l}\text { Húsvéti } \\
\text { rozmaring }\end{array}$ & 8 &, 00 \\
\hline Red Fuji & 13 &, 00 \\
\hline Tenroy & 10 &, 00 \\
\hline Freedom & 10 &, 00 \\
\hline Hesztia & 5 &, 20 \\
\hline Jonagold & 10 &, 20 \\
\hline
\end{tabular}

\begin{tabular}{|l|r|r|}
\hline \multicolumn{3}{|c|}{ időpont=2 kezelés=2 (kontroll) } \\
\hline $\begin{array}{l}\text { Húsvéti } \\
\text { rozmaring }\end{array}$ & 8 &, 00 \\
\hline Hesztia & 5 &, 00 \\
\hline Freedom & 10 &, 10 \\
\hline Tenroy & 9 &, 11 \\
\hline Red Fuji & 13 &, 15 \\
\hline Jonagold & 10 &, 20 \\
\hline ldared & 5 &, 60 \\
\hline
\end{tabular}

\begin{tabular}{|l|c|r|r|}
\hline \multicolumn{4}{|c|}{ kezelés=2 (kontroll) időpont=3 } \\
\hline $\begin{array}{l}\text { Húsvéti } \\
\text { rozmaring }\end{array}$ & 8 &, 00 & \\
\hline Freedom & 10 &, 10 & \\
\hline Tenroy & 9 &, 11 & \\
\hline Red Fuji & 13 &, 15 &, 15 \\
\hline Hesztia & 5 &, 20 &, 20 \\
\hline Jonagold & 10 &, 20 &, 20 \\
\hline Idared & 5 & &, 80 \\
\hline
\end{tabular}

\begin{tabular}{|l|c|r|r|r|r|}
\hline \multicolumn{7}{|c|}{ kezelés=1 (fertőzött) időpont=2 } \\
\hline Red Fuji & 46 & 1,80 & & & \\
\hline Freedom & 46 & 1,89 & & & \\
\hline Hesztia & 37 & 2,32 & 2,32 & & \\
\hline Idared & 36 & & 2,47 & & \\
\hline $\begin{array}{l}\text { Húsvéti } \\
\text { rozmaring }\end{array}$ & 51 & & 2,69 & 2,69 & \\
\hline Jonagold & 50 & & & 3,08 & 3,08 \\
\hline Tenroy & 45 & & & & 3,31 \\
\hline
\end{tabular}




\section{KÖSZÖNETNYILVÁNÍTÁS}

Mindenekelőtt szeretném hálás köszönetemet kifejezni témavezetőmnek, Dr. Tóth Magdolnának, hogy lehetőséget biztosított a tanulmányaimhoz és mindenben támogatta a munkámat, valamint értékes szakmai segítséget nyújtott a dolgozatom elkészültéhez.

Dr. Hevesi Máriának külön köszönöm azt a végtelen türelmet, mellyel az utamat egyengette, hogy megosztotta velem szakmai tudását és segített a kísérleteim megtervezésében és kivitelezésében. Számomra nagyon sokat jelentett, hogy bármikor, bármilyen kérdéssel és kéréssel fordulhattam hozzá, feltétlen segítséget kaptam.

Köszönöm a Gyümölcstermő Növények Tanszék valamennyi munkatársának a segítségét.

Nagyon köszönöm az Alkalmazott Kémia Tanszéken Stefanovitsné dr. Bányai Évának, hogy segített az enzimaktivitás mérések kivitelezésében, valamint felbecsülhetetlen segítséget nyújtott a dolgozatomhoz.

Hálával tartozom dr. Végvári Györgynek, hogy segített a HPLC-vel való szénhidráttartalom meghatározásokban.

Természetesen ez a dolgozat nem jött volna létre a Debreceni Egyetem ATK Nyíregyházi Kutató Intézet Biotechnológiai Laboratóriumának volt és jelenlegi munkatársai nélkül. Nagyon köszönöm a segítségüket.

Hálás vagyok közvetlen felettesemnek, Dr. Dobránszki Juditnak és közvetlen munkatársamnak, Magyarné Dr. Tábori Katalinnak a szakmai és emberi támogatásukért.

Végül, de nem utolsó sorban, köszönet a családomnak a türelmükért, a töretlen biztatásukért és a folyamatos támogatásukért. 